UNIVERSIDADE DE SÃO PAULO

PÓS-GRADUAÇÃO INTERUNIDADES EM ENSINO DE CIÊNCIAS

ROBERTO SOARES DA CRUZ HASTENREITER

Das Palavras aos Quanta: Analogia como Elemento do Pensamento e Ferramenta Didática em Aulas de Física Quântica na Educação Básica 


\title{
Das Palavras aos Quanta: Analogia como Elemento do Pensamento e Ferramenta Didática em Aulas de Física Quântica na Educação Básica
}

\author{
Orientador: Prof. Dr. Ivã Gurgel \\ Tese apresentada ao Instituto de Física \\ da Universidade de São Paulo para \\ obtenção do título de Doutor em Ensino \\ de Ciências- Modalidade Física.
}

Banca examinadora:

Prof. Dr. Ivã Gurgel (IF-USP) (Presidente)

Prof $^{a}$. Dr ${ }^{a}$. Andreia Guerra de Moraes (CEFET-RJ)

Prof $^{\mathrm{a}}$. Dr ${ }^{\mathrm{a}}$. Maria Beatriz Fagundes (UFABC)

Prof. Dr. Michel Henri Lucien George Paty (Univ. Paris VII)

Prof. Dr. Osvaldo Frota Pessoa Junior (FFLCH-USP)

São Paulo 
Autorizo a reprodução e divulgação total ou parcial deste trabalho, por qualquer meio convencional ou eletrônico, para fins de estudo e pesquisa, desde que citada a fonte. 
Aos meus amados pais Emilia e João (in memoriam), sobretudo à minha querida mãe, fonte de minha força e inspiração, cuja lembrança faz parte de meu elã vital.

À minha amiga, companheira e amada esposa Marina, que sempre me apoiou e me incentivou, o que tornou minha caminhada mais suave.

Aos meus queridos irmãos Claudio, Carlos (in memoriam) e Haydée.

Ao meu amado filho Vicente, que desde o ventre de sua mãe me foi fonte de inspiração.

Aos meus querido sobrinhos Beatriz e Bernardo.

À minha madrinha, tia e segunda mãe Sônia, pelo carinho e cuidado.

Ao meu amigo/ irmão Claudio Ferreira (in memoriam), por toda sua confiança e apoio. 


\section{AGRADECIMENTOS}

Ao povo brasileiro, sobretudo, aos milhões de compatriotas que dão ao Brasil mais do que recebem, que pagam em miséria, sofrimento e privações, e que mesmo sem saber contribuíram com a realização da presente tese.

Ao Professor Dr. Ivã Gurgel, pela orientação, incentivo, amizade, respeito profissional e, sobretudo, por aceitar compartilhar comigo sua experiência, dadas as circunstâncias.

Ao Professor Dr. Elio, pela orientação, incentivo, amizade, respeito profissional e confiança.

À Marina, pelo carinho, apoio, paciência e compreensão em todos os sentidos, entendendo muitas vezes minha ausência e acreditando junto comigo neste projeto de vida.

Ao meu grande amigo, pai, companheiro Jorge Kwasinski, pelo incentivo, amizade e, sobretudo, por nunca poupar esforços a fim de criar possibilidade de me ver realizando esse projeto de vida. Muito Obrigado!

Ao meu grande amigo e irmão André Tato, pelo companheirismo, pelas discussões e incentivo. Por sua dedicação e auxilio nos momentos que mais precisei. Pela sincera torcida e valorização. Muito obrigado!!

Ao Professor Dr. Cristiano Mattos, pela amizade, conversas e as muitas contribuições apresentadas.

Ao Professor Dr. Michel Paty, pela amizade, conversas, contribuições e acolhimento na Université de Paris Diderot.

Ao professor Dr. Waldmir Araújo Neto, pela amizade, conversas, contribuições e incentivo.

À professora Dra. Andreia Guerra, pela amizade, conversas, contribuições e incentivo.

Ao professor Dr. Osvaldo Pessoa Junior, pela inspiração, amizade e contribuições.

À professora Dra. Cécile de Hosson, pela oportunidade de conhecer seu grupo de pesquisa, por sua generosidade, contribuições e acolhimento. 
Ao Professor Dr. Ricardo Karam, pela amizade, conversas, contribuições, generosidade e por me acolher na universidade de Hamburg.

À professora Dra. Laurence Viennot, pelo acolhimento, generosidade e contribuições.

Aos colegas de corredor da USP, pelo acolhimento, pelas conversas, reflexões, cafezinhos, chás, dentre os quais destaco André Noronha (família), André Rodrigues, Juliano, Alexandre, Flávia, Leika, Graciella, Glauco, Leonardo, Esdras, Jucivagno, Giselle, Emerson.

Aos colegas de grupo de pesquisa Wellington, George e Alexandre, pela generosidade em compartilhar as aulas videografadas e pelas conversas.

Aos colegas do laboratório SPHERE, que fizeram do meu "sejour en France" uma grande descoberta que ultrapassou os limites de minha questão de pesquisa, dentre os quais destaco Federico, Fabien, Christine, Fernando, Nacéra, Xiaofei, Sergio, Phillipe, Zeinab, Vincent,Jonathan, Eleonora, Ivana, Ramzi.

Aos colegas e professores do laboratório LDAR, pelas contribuições e acolhimento, dentre os quais destaco Luz Martinez, Valentin Maron, Nicolas Decamp, Isabelle Kermen, Rita Khanfour, Wanda Kaminski.

À querida revisora e amiga Renata pelo trabalho primoroso e pela gentileza.

Aos colegas da equipe de Física do IFRJ, que sempre me apoiaram, aliviando minha carga horária e alocando minhas aulas de forma que eu pudesse cumprir com a dinâmica semanal da ponte Rio-São Paulo.

Aos meus sogros Anísio e Joana, que nessa reta final desempenharam um papel fundamental para que eu tivesse condições de trabalhar. Sobretudo à Joana D'arc, que ajudou nos cuidados com meu filho recém-nascido, perdendo horas de sono e de passeio em Paris.

Aos meus amigos e familiares, pelo apoio, dentre os quais destaco toda minha família de Genebra, Luciano Dutra, Serginho, Vanessa, Billy, Medina, e o casal Zita e Mohamed.

À CAPES pela concessão da bolsa PDSE, sem a qual meu estágio no exterior não seria viável.

À Direção do IFRJ, pelo apoio na realização deste trabalho. 


\section{RESUMO}

CRUZ-HASTENREITER, R. S. Das palavras aos quanta: Analogia como elemento do pensamento e ferramenta didática em aulas de física quântica na educação básica. 2015. 338 f. Tese (Doutorado) - Instituto de Física e Faculdade de Educação, Universidade de São Paulo, São Paulo, 2015.

O presente trabalho trata do uso de analogias em atividades didáticas voltadas às aulas de ciências e, mais especificamente, do uso de analogias em aulas sobre temas de física quântica para alunos do ensino médio. Partimos, então, da aparente contradição que resulta da tentativa de abordar conceitos da física quântica, conceitos estes abstratos e sem relação com a realidade sensível, por meio de um mecanismo representativo que é baseado na comparação entre dois domínios do conhecimento, no qual um deles pertence ao repertório do conhecido (familiar) e o outro diz respeito ao que se deseja conhecer. Nossa principal contribuição, ligada à nossa proposição inicial, se dá na medida em que propomos inicialmente reflexões a respeito do conceito de analogia em três dimensões: a primeira, associada à perspectiva da psicologia cognitiva, na qual a analogia se constitui como elemento central do pensamento e assim da formação dos conceitos em toda a história do sujeito; a segunda, relacionada à epistemologia da ciência, especificamente sob a perspectiva de Henri Poincaré, a partir da qual se apontam basicamente três categorias de analogias (figurativas, mecânicas e matemáticas); a terceira, ligada às atividades didáticas que consideram a analogia como ferramenta de aprendizagem, e que busca, a partir de esforços coletivos presentes na literatura especializada em ensino de ciências, sistematizar o seu uso. A partir de uma ampla leitura das três dimensões supracitadas, propomos uma síntese que nos permita um olhar específico para nosso objeto de pesquisa. A fim de analisar o potencial de nossa síntese teórica, realizamos um ensaio empírico que consistiu na elaboração de episódios criados a partir de aulas de temas de física quântica ministradas a alunos do ensino médio (modelos atômicos, efeito fotoelétrico, dualidade onda-partícula, interpretações da Mecânica Quântica). A metodologia usada na interpretação dos episódios pressupõe que analogias em atividades didáticas podem ser classificadas quanto ao seu nível de elaboração, assim como em aspectos ligados ao seu uso, como o formato de apresentação e de ações prévias. Os resultados nos ajudam a perceber situações de uso de analogias prioritariamente figurativas com alguns casos de analogias mecânicas. A ausência de uso de analogias matemáticas, assim como do formato de apresentação matemático-representativo, nos permite reafirmar - caráter crucial de se investigarem novos "formatos" de analogias que sejam adequados à comunicação e ao ensino de conceitos da física quântica.

Palavras chave: Ensino de física, FMC no ensino médio, Analogia, Epistemologia da ciência. 


\begin{abstract}
CRUZ-HASTENREITER, R. S. From words to Quanta: analogies on Quantum Physics Class. 2015. 338 f. Thesis (Doctoral) - Instituto de Física e Faculdade de Educação, Universidade de São Paulo, São Paulo, 2015.
\end{abstract}

This work deals with the use of analogies in teaching activities of sciences and, more specifically, with the use of analogies in high school quantum physics courses. Our starting point is the apparent contradiction of attempting to approach the concepts of quantum physics, abstract and deprived of any relation with the sensory reality, through a mechanism of representation based on the comparison of two fields knowledge: a first one which is known and familiar, and a second one which we wish to grasp. Our main contribution lies in our initial proposition to reflect on the concept of analogy from three different perspectives: first, there is the point of view of cognitive psychology, in which analogy appears as central element of thought and therefore of the formation of concepts during the whole history of the subject; second, there is the point of view of epistemology of science, and particularly that of Henri Poincaré who distinguished three basic categories for analogies (figurative, mechanical and mathematical); third, there is the point of view of educational activities, which considers analogies as a learning tool and attempts, through collective efforts manifested in the science education literature, to provide a systematic account of their use. Based on an ample reading along the three aforementioned dimensions, we then propose a synthesis enabling us to adopt a specific look at our object of research. In order to analyse the potential of this theoretical synthesis, we have conducted an empirical test constituted by episodes created within high school quantum physics lectures (atomic models, the photoelectric effect, the wave-particle duality, and the interpretations of Quantum Mechanics). In order to interpret these episodes, the methodology assumes that analogies in teaching activities can effectively be classified according to their level of development and to some aspects of their use, such as the presentation format and the previous actions. The results help us in perceiving how most of the analogies used are figurative, even though there are also some mechanical analogies. The lack of use of mathematical analogies, as well as the absence of the mathematicalrepresentative presentation format, allows us to reaffirm the crucial need of investigating new "formats" of analogies, better suited for the communication and teaching of the concepts of quantum physics.

Keywords: physics education, Modern and Contemporary Physics in high school, analogy, epistemology of science. 


\section{LISTA DE FIGURAS}

Figura 3.1 Modelo do sistema de atividades de Engeström

Figura 4.1 Esquema de sequência de peças de dominó 92

Figura 4.2 Superposição de ondas: (a) construtiva (ondas em fase); (b) destrutiva (ondas fora de fase)

Figura 4.3 Experimento de dupla fenda para a luz

Figura 4.4 Formação paulatina do padrão de interferência

Figura 4.5 Feixe emitido por uma fonte laser é dividido em duas partes A e B de igual amplitude

Figura 4.6 Esquema do interferômetro de Mach-Zehnder

Figura 4.7 Versões do interferômetro de Mach-Zehnder nos quais seria possível determinar a trajetória do fóton emitido pela fonte LASER: (a) o espelho semi-refletor S1 é substituído pelo espelho de reflexão total E0; (b) o espelho semi-refletor S1 é removido 123

Figura 4.8 Esquemas para o "fenômeno ondulatório": (a) experimento de correlação; (b) fenômeno corpuscular obtido a partir do interferômetro de Mach-Zehnder ..... 125

Figura 4.9 Densidades de probabilidade da velocidade das moléculas de quatro gases nobres a $25{ }^{\circ} \mathrm{C}$. O pico de cada gráfico indica a velocidade dominante em cada gás na referida temperatura 
Figura 5.1 Circuito simples de uma lanterna

Figura 5.2 Analogia do trem contínuo 146

Figura 5.3 Uma célula animal como uma fábrica 157

Figura 5.4 Medula Espinhal 160

Figura 5.5 Três níveis de elaboração de analogias 161

Figura 5.6 Esquema (1) feito no quadro 166

Figura 5.7 Esquema (2) feito no quadro 167

Figura 6.1 Níveis de analogias 192

Figura 6.2 Fragmento do mapa de eventos relativo a aula 02 200

Figura 6.3 Fragmento do mapa de eventos relativo a aula 04 205

Figura 6.4 Fragmento do quadro relativo ao episódio 02 206

Figura 7.1 Fragmento do episódio 05 (MAT - 04 - 14032011 - 02) 211

Figura 7.2 Episódio 03 (EFE - $03-14032011$ - 05) 212

Figura 7.3 Fragmento do episódio 03 214

Figura 7.4 Fragmento do episódio 01 216 
Figura 7.5 Fragmento (a) do episódio 02

Figura 7.6 Fragmento (b) do episódio 02 218

Figura 7.7 Fragmento (a) do episódio 04 219

Figura 7.8 Fragmento (b) do episódio 04 220

Figura 7.9 Fragmento (c) do episódio 04 221

Figura 7.10 Fragmento do episódio 05 222

Figura 7.11 Fragmento (a) do episódio 06 224

Figura 7.12 Fragmento (b) do episódio 06 225

Figura 7.13 Fragmento do episódio 07 226

Figura 7.14 Fragmento (a) do episódio 08 227

Figura 7.15 Fragmento (b) do episódio 08 228

Figura 7.16 Fragmento (2) do episódio 01 231

Figura 7.17 Fragmento (2) do episódio 02 232

Figura 7.18 Fragmento (2a) do episódio 04 233

Figura 7.19 Fragmento (2b) do episódio 04 234 
Figura 7.20 Fragmento (2) do episódio 05 235

Figura 7.21 Fragmento (2) do episódio 06 236

Figura 7.22 Fragmento (2) do episódio 07 237

Figura 7.23 Fragmento (2) do episódio 08 238

Figura 7.24 Fragmento (3) do episódio 01 240

Figura 7.25 Fragmento (3) do episódio 02 241

Figura 7.26 Fragmento (3) do episódio 04 242

Figura 7.27 Fragmento (3) do episódio 05 243

Figura 7.28 Fragmento (3) do episódio 06 244

Figura 7.29 Fragmento (3) do episódio 07 245

Figura 7.30 Fragmento (3) do episódio 08 246 


\section{LISTA DE QUADROS}

Quadro 2.1 Artigos de periódicos analisados no período de 1997 a 2009

Quadro 2.2 As categorias e os artigos relacionados

Quadro 2.3 Tabela de trabalhos relacionados ao uso de representações no Ensino de Ciências e do uso de analogias de 1990 à 2012

Quadro 5.1 Conjunto de atividades didáticas baseadas em analogias (Silva et al., 2005)

Quadro 5.2 Síntese das etapas do FAR guide

Quadro 5.3 Quadro análogo x alvo (analogia do trem contínuo)

Quadro 5.4 Etapa Foco (analogia do trem contínuo)

Quadro 5.5 Etapa Ação (analogia do trem contínuo)

Quadro 5.6 Etapa Reflexão (analogia do trem contínuo)

Quadro 6.1 Características que orientam a análise metodológica da categoria "nível"

Quadro 6.2 Relações entre os domínios em cada nível de analogia

Quadro 6.3 - Episódio 02 (MAT -02-11032011-06)

Quadro 6.4 Características que orientam a análise metodológica da categoria formato de apresentação 
Quadro 6.5 Características que orientam a análise metodológica da categoria "Ações Prévias"

Quadro 6.6 Características do item "natureza do evento" para o mapa de eventos

Quadro 6.7 Características do item "tópicos" para o mapa de eventos 202

Quadro 6.8- Características do item "recursos" para o mapa de eventos 203

Quadro 6.9 Padrão de identificação dos episódios 205

Quadro 7.1 Classificação em categorias do episódio 03 215

Quadro 7.2 Formato de Apresentação em Curtis e Reigeluth (1984) 229

Quadro 7.3 "Novas" categorias quanto ao Formato de Apresentação 230

Quadro 7.4 Classificação em categorias dos episódios 247 


\section{SUMARIO}

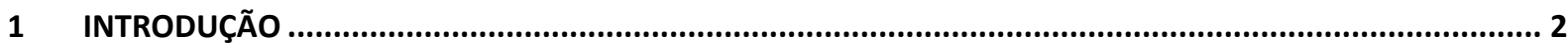

1.1 BREVE RECONSTRUÇÃO HISTORICA DO PROBLEMA DE PESQUISA.................................................................

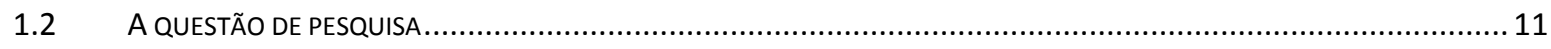

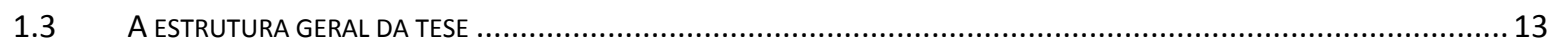

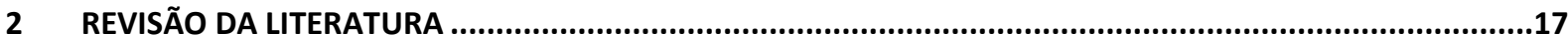

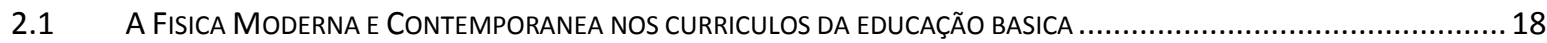

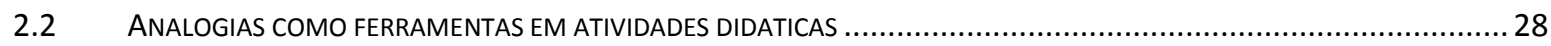

$3 \quad$ ANALOGIAS E A FORMAÇÃO DE CONCEITOS.............................................................................................

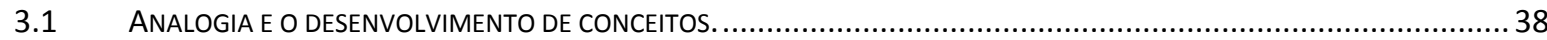

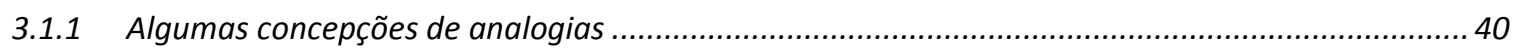

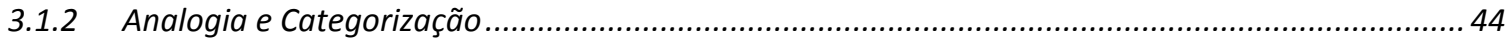

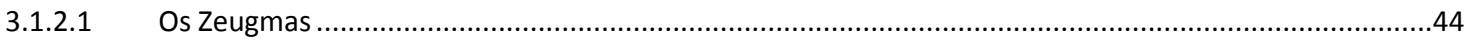

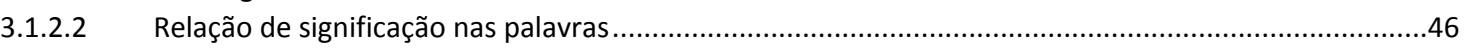

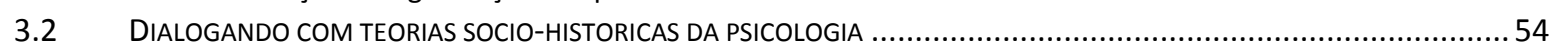

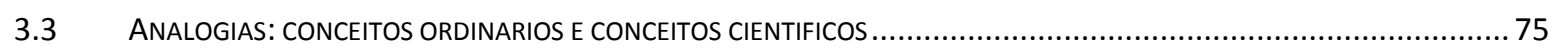

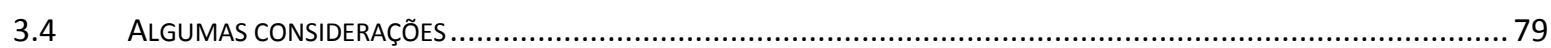

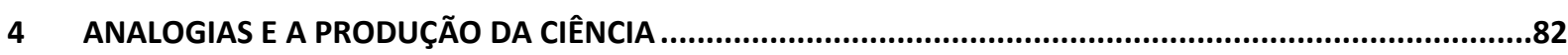

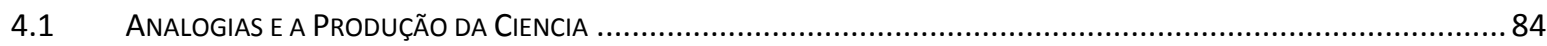

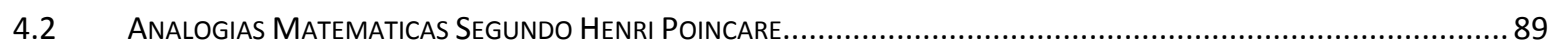

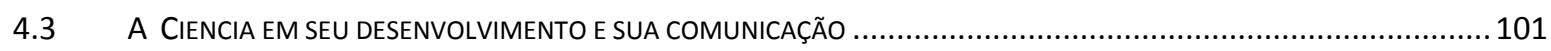

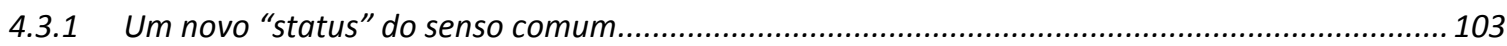

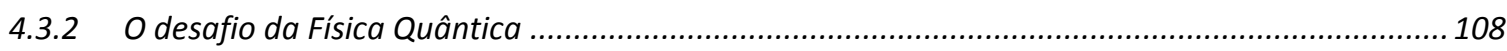

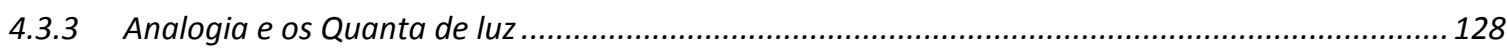

5 O USO DE ANALOGIAS E METÁFORAS NAS AULAS DE CIÊNCIAS .......................................................138

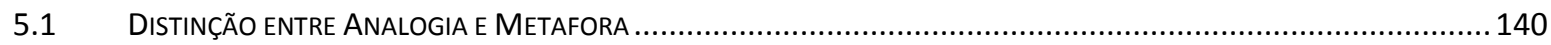

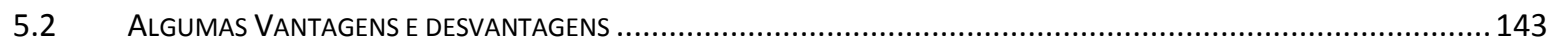

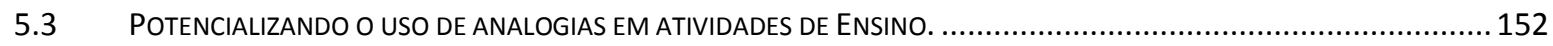

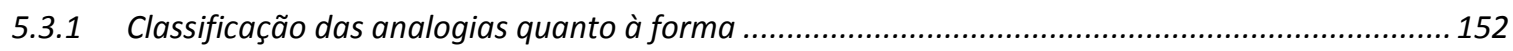

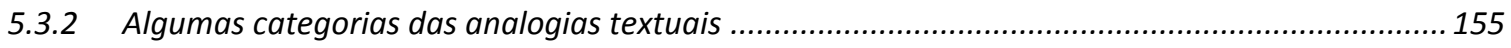

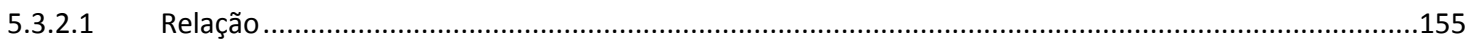

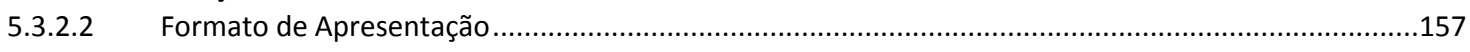

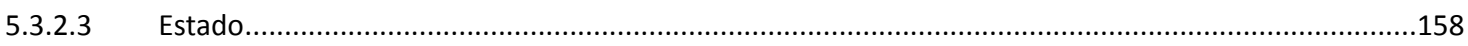

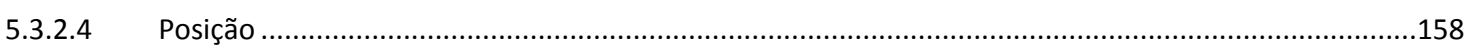

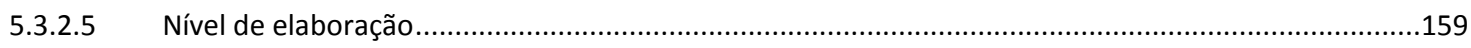

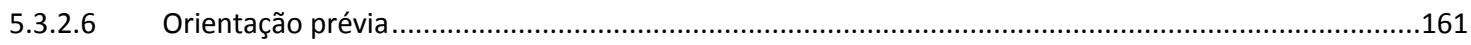

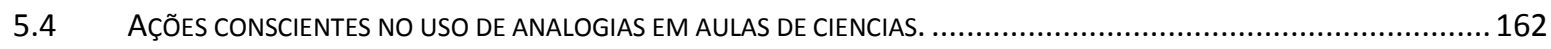

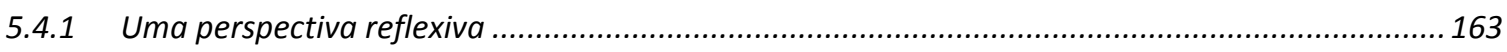

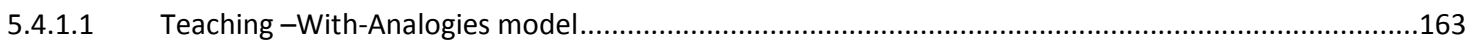

5.4.2 Uso de analogias como elemento na formação de professores .................................................. 171

5.4.2.1 Focus-Action-Reflection (FAR) Guide: (Foco-Ação-Reflexão) - Um Guia para o uso de analogias em

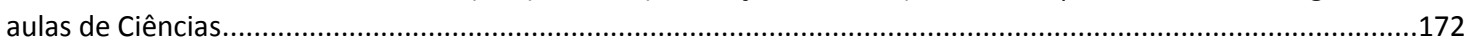

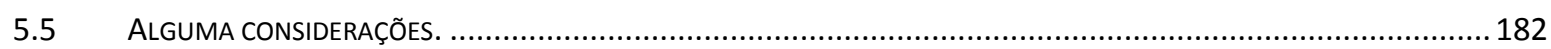

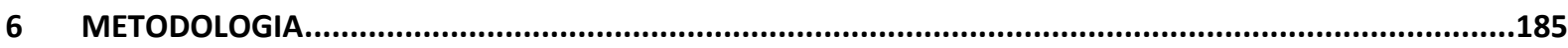

6.1 CARACTERISTICAS DA PESQUISA REALIZADA

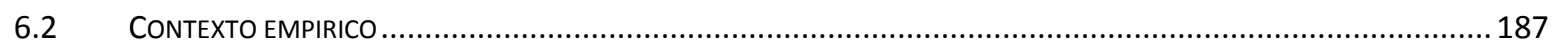

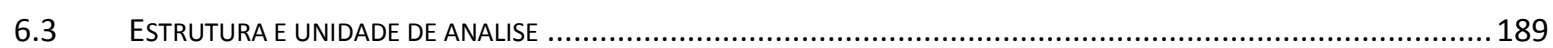




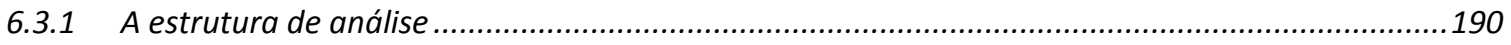

6.3.1.1 Níveis de analogias usadas em atividades didáticas no ensino de física .............................................. 191

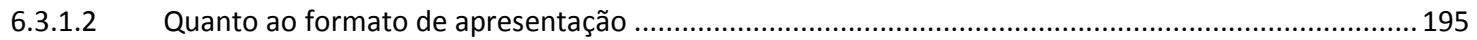

6.3.1.3 Inclusão das atividades didáticas de uso de analogias no planejamento .............................................197

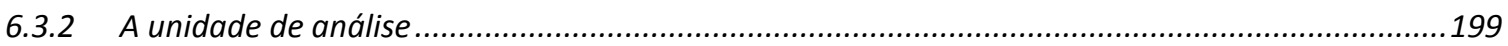

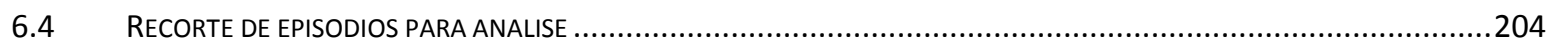

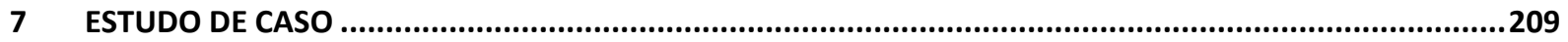

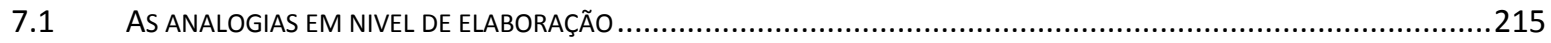

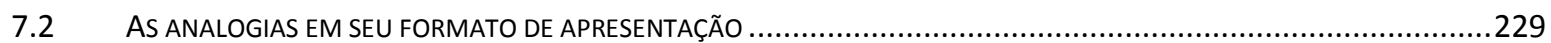

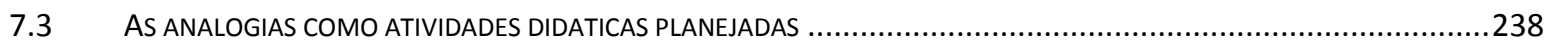

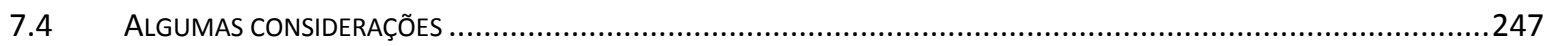

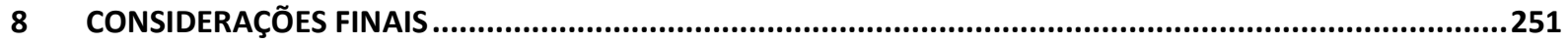

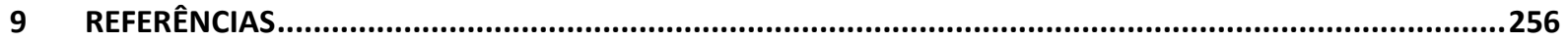




\section{CAPÍTULO 1}




\section{INTRODUÇÃO}

O ensino de tópicos da física desenvolvida no século $X X$ a alunos da educação básica, também chamada no campo de pesquisa em ensino de ciências de Física Moderna e Contemporânea (FMC), tem ocupado espaço significativo em trabalhos dessa área de pesquisa e é objeto de debates há algumas décadas (GIL et al.,1987; JONES, 1991; TERRAZZAN, 1992; GIL e SOLBES, 1993; PINTO e ZANETIC, 1999; OSTERMANN e MOREIRA, 2000; BROCKINGTON, 2005; PEREIRA e OSTERMANN, 2009; SHINOMIYA, 2013). Sobretudo as questões envolvidas na possibilidade do ensino de FMC nas escolas de nível médio perpassam diversos temas de pesquisa relacionados aos processos educativos, dentre os quais destacamos a inovação curricular e a formação de professores (PIETROCOLA, 2010).

Diversos argumentos são apresentados a favor da inserção de tópicos de FMC na educação básica. Para Zanetic (1989), a física deve ser compreendida como um continente cultural a ser desvelado. Como herança cultural, a física do século XX deve ser acessível aos cidadãos do mundo contemporâneo. Desta forma, é importante que empenhemos esforços a fim de permitir aos alunos apreender os conceitos associados à FMC, levando os estudantes a perceber de que maneira tais conceitos podem apontar novas visões e formas de ação no mundo. Em uma perspectiva próxima a esta, Brockington (2005) destaca que o esforço em trazer tópicos da física do século XX está em conformidade com as diretrizes e bases da educação nacional vigentes desde a década de noventa, diretrizes que apontam para a necessidade de os saberes escolares estarem mais próximos da vida dos alunos e, assim, garantir a formação de cidadãos mais críticos e conscientes sobre como a ciência atual se relaciona com a sociedade.

As novas tecnologias da comunicação e da informação permeiam o cotidiano, independente do espaço físico, e criam necessidades de vida e convivência que precisam ser analisadas no espaço escolar. A televisão, o rádio, a informática, entre outras, fizeram com que os homens se aproximassem por imagens e sons de mundos antes inimagináveis. (BRASIL, 1999, p.132).

Algumas das justificativas de apoio à inserção de tópicos introdutórios da Física do século XX na educação básica se dão na perspectiva da formação de 
cidadãos não alienados às práticas e às questões relacionadas à sua época, visto que, por exemplo, grande parte da Física Quântica é base do desenvolvimento tecnológico, seja na área das engenharias, da telecomunicação ou da medicina. Como afirma Greca:

[...]Demais dizer que este interesse é muito justificado. Em parceria com a Relatividade, a Mecânica Quântica é a grande estrela do século XX. Base de sustentação da física nuclear, atômica, molecular e do estado sólido, da física das partículas elementares e da luz, seus impactos práticos atingem hoje as mais variadas aplicações, beneficiando até campos de praticidade imediata como as Ciências da Saúde e as Engenharias. Mais ainda, os desenvolvimentos recentes na miniaturização eletrônica e na nanotecnologia têm introduzido, até no mundo dos negócios, dispositivos que somente podem ser apreciados a partir dos princípios da Mecânica Quântica. Se até agora este conhecimento estava reservado aos estudantes de Física e de Química, parece inevitável que a maioria dos profissionais deste novo século deva ter um conhecimento a este respeito bem mais aprofundado que o necessário até então.(GRECA, 2001, p.444)

A importância educacional de temas de FMC permitiu que os mesmos fossem inseridos em currículos oficiais de muitos países. Lobato e Greca (2005) fazem um levantamento de como a Teoria Quântica (TQ) e temas semelhantes estão presentes nos currículos de países como Portugal, Espanha, França, Dinamarca, Reino Unido, Suécia, Canadá e Austrália, demonstrando sua forte presença. Além do levantamento, os autores propõem uma análise da inserção de conteúdos de TQ nos currículos de Física do Ensino Médio e, como conclusão, apontam que uma vez que tópicos de FMC já fazem parte do currículo oficial de muitos países, estando assim demonstrada a pertinência destes assuntos, o próximo passo seria pensar nas melhores maneiras de se trabalhar os conceitos de TQ no Ensino Médio. Conforme destacam Lobato e Greca:

Tendo concluído que os conteúdos da TQ, de fato, já fazem parte de programas oficiais do $E S^{1}$, é necessário passar à questão seguinte : qual será a melhor maneira de os abordar? Não se pode ignorar que as tentativas de ensinar a TQ a cursos introdutórios , tanto do ES como do Superior, têm contribuído para o aparecimento de conceitos errôneos que só podem ter origem na instrução , já que não há "senso comum" ou "teorias alternativas" que os expliquem. Assim, parece-nos que as próximas questões de investigação devem estar

\footnotetext{
${ }^{1}$ No presente artigo, os autores utilizam ES para indicar Ensino Secundário, o que é equivalente ao Ensino Médio.
} 
relacionadas com a melhor maneira de ensinar os primeiros conceitos de TQ, especialmente no ES, o que certamente contribuirá para que, posteriormente, no Ensino Superior, os alunos detenham conceitos mais de acordo com a perspectiva científica. (LOBATO e GRECA, 2005, p.130).

Inserindo-se, então, no coletivo de pesquisas que se preocupam em ensinar conceitos de teorias do século $X X$, como a quântica e a relatividade, a presente tese se apresenta como mais uma contribuição no esforço de incluir nos currículos de física da educação básica tópicos da FMC. Em especial, este trabalho analisa propostas realizadas para o Ensino Médio e focaliza o uso de analogias nas aulas de $F Q$.

Como professores de Física, em nossa intenção de ensinar ciências, utilizamos várias ferramentas de mediação, a saber, a linguagem (falada e escrita), representações gráficas, pictóricas, dentre outras que se apresentam como tentativa de simbolizar a realidade a ser estudada e compreendida. No entanto, no domínio da Física Moderna e Contemporânea (FMC), deparamo-nos com alguns obstáculos (OSTERMANN e MOREIRA, 2001), que podem ser interpretados como sendo de ordem ontológica ou epistemológica, na tentativa de representar as entidades em questão. Com o advento da Física Quântica (FQ), surge um problema relacionado com a questão da quebra da objetividade. Segundo von Weizsäcker, citado por Pessoa:

Uma entidade microscópica seria algo incompreensível, em toda sua totalidade, para o entendimento humano; este só pode compreender esta entidade sob uma certa perspectiva, que é ora corpuscular, ora ondulatória.

Para von Weizsäcker (1944, p. 123), a marca distintiva da física quântica não é a quebra do princípio de causalidade, mas é a perda do que chama de objetividade, ou seja, a possibilidade de "construir e arquitetar, com os diversos fragmentos da nossa intuição e as diferentes séries causais, o modelo de uma Natureza existindo em si mesma". A mecânica quântica violaria o princípio (da física clássica) de que "o não-percebido deve ter as mesmas qualidades que o percebido" (p. 116). Só podemos conceber uma realidade enquanto ela é observada de uma certa perspectiva , e não existindo em si mesma. Isso não implica necessariamente um idealismo radical que afirmaria que sem observadores não existiria o mundo. Mas reforça a postura kantiana de que não faz sentido conce ber um objeto independente de um sujeito cognoscente. (PESSOA, 2003a, p.31516) 
A dificuldade de representar as "entidades" que von Weizsäcker (ibid.) considera "incompreensíveis" nos leva a questionar quais recursos cognitivos podem ser mobilizados para a compreensão destes conceitos. Além disso, pode-se questionar como professores de Física podem mobilizar estes recursos de modo a promover o aprendizado de conceitos de FQ. Neste contexto, como indicado anteriormente, esta tese se propõe a analisar o papel das analogias no aprendizado de $F Q$ com especial atenção ao seu uso por professores.

Antes de sistematizarmos a questão de pesquisa, apresentaremos um breve histórico das motivações que levaram o autor deste trabalho a refletir sobre este tema.

\subsection{Breve reconstrução histórica do problema de pesquisa}

Nossa relação com a pesquisa em ensino de física não se inicia no doutorado. Ao contrário, ela se potencializa e recupera questões outrora construídas. Na verdade, se desejamos melhor entender a pergunta de pesquisa aqui tratada, é necessário recuperar nosso "percurso de formação", a fim de deixar mais claro "quem fala" e de "onde fala". Incorporamos, desde a concepção da presente tese, a perspectiva da construção do conhecimento como um processo histórico e coletivo. Nesse sentido, propomos uma breve análise de nosso percurso de formação acadêmica, a partir do relato das questões que julgamos mais pertinentes ao objetivo supracitado.

Formado em Licenciatura em Física pela Universidade Federal Rural do Rio de Janeiro (UFRRJ) em 1995, iniciei na carreira do magistério antes mesmo de obter meu diploma de licenciado em Física. No início do ano de 1994, comecei a lecionar matemática em escolas particulares em Campo Grande, na cidade do Rio de Janeiro, e em Itaguaí, cidade vizinha à UFRRJ. Dentro da mesma rede de escolas, iniciei como professor de física em 1996. No ano seguinte fui contratado pela FAETEC (Fundação de Apoio a Escola Técnica - RJ), onde atuei como professor de física em turmas de cursos técnicos de mecânica, eletrônica e eletrotécnica. No mesmo ano, fui aprovado no concurso para professores na rede estadual de ensino do Rio de Janeiro e fui convidado a trabalhar em um colégio tradicional no bairro do 
Méier. Somado às minhas atividades profissionais, cursava o bacharelado em física na Universidade do Estado do Rio de Janeiro (UERJ).

Em minha busca por tornar as aulas mais significativas e interessantes, e talvez influenciado por minha experiência como monitor de física experimental na universidade, tentei sempre incorporar práticas experimentais em meus cursos de física no ensino médio. Como na maioria das vezes os colégios não eram equipados com laboratórios, eu mesmo construía, geralmente com material de baixo custo, experimentos os quais eram utilizados em minhas aulas, alguns demonstrativos e outros demandando que os alunos fizessem algumas medições. Em outras situações, os alunos tinham como tarefa a construção de um "artefato" experimental (câmara escura, circuito elétrico simples com lâmpadas, canhão de lançamento oblíquo ...) que seria utilizado por eles em sala em uma aula prática.

Foi então que, a partir dessa vontade de tornar minha atividade profissional mais significativa para os alunos assim como para mim mesmo, e baseado na relação empírica imediata proveniente de minhas práticas enquanto professor, as questões a respeito das aulas de física aumentavam e faziam com que eu buscasse cada vez mais "aportes teóricos". Inicialmente isso se deu através da participação em oficinas de laboratórios didáticos oferecidas pelas universidades, assim como em minicursos e escolas de verão oferecidos pelo CBPF.

Em 2002, fui aceito no programa de pós-graduação lato sensu em Ensino de Ciências da Universidade Federal Fluminense (UFF). Durante o primeiro ano, cursamos disciplinas como Introdução à Filosofia da Ciência, Políticas Públicas, Metodologia de Pesquisa e Instrumentação para o Ensino de Ciências. O contato com as disciplinas, com os colegas de curso e com os professores do programa foi fundamental para que tivesse certeza do caminho a trilhar.

Três anos depois, fui aprovado no concurso para professor efetivo do Instituto Federal do Rio de Janeiro (na época CEFET Química de Nilópolis-RJ), o que fez com que eu reduzisse significativamente minha carga horária e diminuísse o número de escolas nas quais trabalhava. Tal fato me permitiu, no ano seguinte, ingressar no programa de pós-graduação em Ensino de Ciências e Matemática do CEFET-RJ. Ainda em uma postura "híbrida", na qual o papel de professor da educação básica, técnica e tecnológica, com todo o seu pragmatismo e por vezes com uma postura 
ingênua, buscava soluções gerais a partir de reflexões contextualizadas trazidas pelos professores do programa em questão. No entanto, julgo que essa postura criticável foi elemento motriz na busca de aperfeiçoamentos e novos pensares.

Destaco aqui três disciplinas cursadas no mestrado que foram fundamentais na construção de minhas questões de pesquisa, a saber, Introdução aos Estudos de CTS, História da Ciência e Física Moderna. A partir das questões apresentadas e discutidas nas referidas disciplinas, e tendo sempre como "pano de fundo" as questões provenientes de minha realidade sensível como professor, nosso problema de pesquisa do mestrado começou a ser delineado. Mais especificamente, as questões que permitiam olhar para ciência como construção humana cujo contexto sócio-histórico cria as condições de trabalho reais a cada época, assim como a perspectiva das mudanças sociaisresultantes do desenvolvimento da ciência, pareciam estar de acordo com o que eu inconscientemente buscava. Sobretudo, foi a partir das aulas do curso de física moderna com a professora Andreia Guerra que pensei na possibilidade de incorporar tais tópicos em minhas aulas de física. À época, lecionava no curso integrado (médio e técnico) em turmas do $3^{\circ}$ ano do ensino médio e decidi incorporar discussões a respeito da relatividade restrita de Einstein. Ainda em uma "percepção bruta" da relação direta com meus alunos, observei que estudantes que outrora não se interessavam pelas aulas de física começaram a participar entusiasmadamente. Tal percepção me levou a pensar na possibilidade de apresentar a teoria da relatividade restrita em séries iniciais, a fim de gerar o referido entusiasmo no "primeiro contato" dos alunos (ao menos formalmente) com a física. Nisto se baseou nossa dissertação de mestrado, em que buscamos construir de forma lúdica textos que seriam aplicados a alunos do $9^{\circ}$ ano do ensino fundamental, apresentando o conceito de movimento e as grandezas físicas associadas, de Aristóteles a Einstein. Dentre as questões incorporadas à pesquisa, destacamos duas perspectivas que se destacam em nossa trajetória e que, em conjunto com as demais leituras, disciplinas e discussões ocorridas na fase do doutorado, compõem as reflexões que nos conduziram à atual pesquisa, a saber, a história da ciência na perspectiva do ensino e a introdução de tópicos de Física Moderna e Contemporânea na educação básica.

Tendo ingressado no programa de pós-graduação Internuidades em Ensino de Ciências em 2011, nosso projeto inicial buscava entender como a participação de 
professores de Física do Ensino Médio no processo de elaboração/aplicação de sequências didáticas no modelo TLS - Teaching Learning Sequence - de temas de Física Moderna e Contemporânea, influenciaria em sua prática docente, e como as questões discutidas e construídas coletivamente seriam representadas nos contextos "individuais" de sala de aula de cada professor envolvido no processo.

No entanto, foi a partir de 2012 que nosso foco mudou. Ainda voltados à formação de professores, assim como aos temas de Física Moderna e Contemporânea em aulas do Ensino Médio, nossa nova pergunta de pesquisa nasceu como uma questão mais ampla, relacionada ao uso de representações na comunicação e ensino de conceitos da Física Quântica. Tal questão foi proveniente de reflexões originárias de duas disciplinas cursadas na Universidade de São Paulo no referido ano (Perspectivas Epistemológicas e Filosóficas do Conhecimento Científico, ministrada pelo professor Dr. Michel Paty; Fundamentos da Mecânica Quântica, ministrada pelo professor Dr. Osvaldo Pessoa Jr.).

Conheci o professor Michel Paty por ocasião da disciplina Perspectivas Epistemológicas e Filosóficas do Conhecimento Científico, oferecida pelo Instituto de Eletrotécnica e Energia (IEE) da Universidade de São Paulo (USP). Como aluno regular da disciplina, participei das atividades previstas, dentre as quais apresentei um seminário a respeito do papel da linguagem no compartilhamento de significados, tendo usado como bases teóricas o conceito de mediação de Wertsch e a filosofia da linguagem de Bakhtin. Na ocasião fui apresentado pelo professor Michel Paty à Filosofia das Formas Simbólicas do filósofo alemão Ernst Cassirer. No mesmo período, cursava a disciplina Fundamentos da Mecânica Quântica (MQ) com o professor Osvaldo Pessoa Jr., na qual discutíamos questões de ordem epistemológica e ontológica das entidades microscópicas. Inicialmente, tomamos o experimento do Interferômetro de Mach-Zehnder e, mais que resolver problemas clássicos da $M Q$, centrávamo-nos em questões como: por qual caminho rumou 0 Fóton? Na tentativa de "responder" a essa pergunta, buscávamos pensar nas quatro interpretações da $\mathrm{MQ}$ enfatizadas no curso: a interpretação ondulatória, a interpretação corpuscular, a interpretação dualista realista e a interpretação da complementaridade. Os arranjos experimentais eram modificados a fim de que novas questões fossem incorporadas às discussões anteriores. 
O curso foi oferecido a alunos da Programa de Pós-Graduação Interunidades em Ensino de Ciências, da Universidade de São Paulo. No entanto, alguns alunos de outras áreas, como Filosofia e Cinema, assistiram às aulas, pois se tratava de uma abordagem conceitual da MQ. Dada a característica heterogênea da turma, esperávamos que as maiores dificuldades estivessem concentradas no grupo de alunos com formação não específica em Ciências da Natureza. No entanto, a abordagem conceitual com forte base filosófica trouxe muito desconforto a alguns alunos com formação em Física. ${ }^{2}$

Sob uma percepção pessoal, como aluno da disciplina e como doutorando na área de Ensino de Ciências, dei-me conta de que o desconforto por parte dos alunos que cursavam a disciplina podia estar ligado às dificuldades associadas ao objeto de estudo em questão. Parecia que Ihes faltavam elementos da experiência pregressa que lhes permitissem associar as "novas questões", em outras palavras, parecia que o referido desconforto estava associado à falta de possibilidade de se fazer analogias, evocando elementos de suas experiências anteriores.

As experiências acumuladas no curso das duas disciplinas supracitadas me conduziram à pergunta geral de pesquisa, assumindo como fundamentais as discussões relacionadas à Filosofia da Ciência ${ }^{3}$ no ensino. No início de 2012, tendo recebido o convite da professora Cécile de Hosson, fui à Université Paris 7 - Dennis Diderot, onde participei da $12^{\mathrm{e}}$ Journée d'etude de l'école doctorale «Savoirs scientifiques", assim como de atividades e reuniões com o grupo de pesquisa do laboratório de Didática das Ciências sob o acompanhamento da professora Cécile, e de conversas com o professor Michel Paty. Nessa oportunidade discutimos de que forma o referencial da Filosofia das Formas Simbólicas poderia se apresentar como um elemento novo nas discussões a respeito do uso de representações no ensino de $M Q$, aproximando-se do nosso problema de pesquisa.

\footnotetext{
2 Tal afirmação se baseia na percepção pessoal do autor. Não obstante, essa percepção é fundamentada em depoimentos de colegas que compartilharam sua dificuldade em entender as proposições do professor, pois, segundo eles, no curso de Física tais questões não apareciam. O que, de fato, importava não era a concepção filosófica adotada, e sim, uma vez definida como base de análise a interpretação da complementaridade, que resultados extraímos.

${ }^{3}$ Há diversos trabalhos que apontam para a relevância da abordagem sob a perspectiva da História e Filosofia da Ciência em pesquisas em Ensino de Ciências (e.g, Gil-Pérez, 1993; Martins , 2006; Matthews, 1997; Vannucchi, 1996).
} 
Nossa motivação foi reforçada pelo incentivo dos professores Michel Paty e Osvaldo Pessoa que, mesmo não tendo como área principal de pesquisa o Ensino de Física, apontaram minha perspectiva de pesquisa como interessante e promissora, visto que já existe uma aproximação do referencial teórico da filosofia com a Física Quântica, cabendo a mim buscar possíveis aproximações com o ensino.

Em 2013, tendo sido aprovado no Programa de Doutorado Sanduíche no Exterior (PDSE), da Capes, integrei-me ao grupo de pesquisa do Laboratoire d'Epistémologie et Histoire des Sciences - SPHERE (História e Filosofia da Ciência) da Université de Paris Diderot - Paris 7 - sob a coorientação do professor Michel Paty. Além de participar das atividades e seminários vinculados ao referido grupo de pesquisas, também participei das atividades ligadas ao Laboratoire de Didactique André Revuz - LDAR, sob a direção da Profa. Dra. Cécile de Hosson. Foi então que, à medida que apresentava meu trabalho tanto aos colegas do SPHERE, quanto aos colegas do LDAR, e a partir das contribuições recebidas, nossas reflexões teóricas do campo da epistemologia foram se aproximando das ideias concernentes ao desenvolvimento da ciência do físico, matemático e filósofo da ciência francês Henri Poincaré. Conforme buscávamos superar a contradição entre o uso de analogias como ferramenta potencial na comunicação de conceitos ligados a ciência, e a inexistência de relações diretas com a realidade física inerentes aos conceitos e entidades da física quântica, a epistemologia da ciência desenvolvida por Poincaré se mostrava, de acordo com a nossa perspectiva, como potencialmente adequada ao nosso problema de pesquisa, voltado à possibilidade de usos de analogias em atividades de ensino direcionadas aos conceitos de física quântica para alunos do ensino médio. 


\subsection{A questão de pesquisa}

As ideias de questões inicialmente são vagas, de forma geral. Assim, requerem análise cuidadosa para que venham a se transformar em projetos de pesquisa precisos e estruturados (SAMPIERI et al., 2006).

Questões relativas ao problema de representação dos conceitos/entidades da $M Q$ apareceram durante o curso ministrado pelo professor Osvaldo Pessoa, de onde surgiu um primeiro questionamento ligado ao ensino de física: "como ensinar física quântica, sobretudo a alunos do ensino médio, uma vez que seus conceitos/entidades 'não podem ser representados', ao menos no senso de correspondência com as 'coisas conhecidas' do mundo macroscópico?'

A seguir, uma segunda questão pode ser entendida como derivada da precedente, "que tipos de representações são adequadas à comunicação dos conceitos/entidades da MQ?". Ainda sem a pergunta de pesquisa bem delimitada, nos pareceu que possíveis respostas a estas perguntas seriam provenientes de uma análise epistemológica da física quântica. Ainda que reconhecendo que a atividade de produção do conhecimento científico difere da atividade de ensino deste, apontamos que ambas guardam entre si semelhanças. Destacamos que a atividade associada à produção da ciência se dá na tentativa de compreender algo desconhecido, enquanto no ensino se deseja fazer compreender algo que foi outrora, de alguma maneira, estruturado e/ou explicado.

A partir do levantamento bibliográfico sobre o tema representações no ensino de ciências, encontramos diversos trabalhos distribuídos em algumas categorias. Basicamente, segundo Waldrip e Prain (2012), duas são as perspectivas voltadas à aprendizagem a partir e por meio de representações. A primeira diz respeito à construção de representações tendo como base a investigação de fatores que afetam a aprendizagem a partir das interações dos estudantes com estas representações. Isso remete, portanto, à forma como os conteúdos são apresentados aos alunos. Já a segunda perspectiva visa a explorar não o uso de representações, mas, anteriormente a essas, a construção das mesmas pelos alunos, incorporando, inclusive, as novas tecnologias como estratégia de promoção 
da alfabetização científica. Nossa pesquisa se insere no contexto da primeira perspectiva.

Vale ressaltar que nosso problema de pesquisa nasce da dificuldade de representação das entidades associadas à física quântica. Tal questão nos aproximou de uma forma de representação particular, com relativa frequência nos trabalhos encontrados sobre este assunto, a analogia. Tal forma está vinculada, fundamentalmente, às tentativas de representar "entidades" pertencentes ao domínio dos conceitos com considerável nível de abstração. Apesar de reforçarmos a ideia peculiar de representar os conceitos/entidades da física quântica, percebemos que a dificuldade de representação no contexto do ensino de ciências não lhe é exclusiva. Por isso, começamos nossa pesquisa a partir das considerações já existentes relativas ao uso de analogias em atividades de ensino de ciências.

Mesmo existindo uma vasta quantidade de trabalhos ligados ao uso de analogias em aulas de ciências, estes se constituem basicamente em ações didáticas. Percebemos, então, a necessidade de ampliar o olhar sobre as analogias, a fim de entendê-las dentro de um processo mais geral, a saber, na formação de conceitos no desenvolvimento do pensamento dos sujeitos. A fim de entender o papel das analogias no processo de cognição, lançamos mão da perspectiva que coloca a analogia como elemento participante do processo. A obra que se apresentou como elemento de fundamental importância para nossa reflexão teórica foi o livro "L’Analogie Coeur de la Pensée" (Holfstadter D. et Sander E., 2013). A leitura do referido livro, que aponta para o par dialético categorização/analogia como - motor do pensamento, trouxe elementos que dão à analogia um status fundamental no processo de formação de conceitos, de inspiração para a nossa imaginação e mesmo a coloca como fonte de novas descobertas.

Visto que nosso problema de pesquisa surge de reflexões ontológicas/epistemológicas da $\mathrm{MQ}$, buscamos, no campo da epistemologia da ciência, elementos que contraponham ou complementem a posição da psicologia cognitiva adotada. Partimos, então, das obras de Henri Poincaré, filósofo da ciência francês, que viveu entre a segunda metade do século XIX e a segunda década do século XX, e buscamos, através de suas análises epistemológicas, compreender o 
papel da analogia no pensamento científico, sobretudo na relação com o novo conhecimento.

Questões ligadas ao uso de analogias em aulas de física quântica serão norteadas, na presente tese, por elementos constituintes da nossa tríplice abordagem: analogia e ensino de ciências; analogia e cognição; analogia e epistemologia da ciência. É, então, a partir das considerações supracitadas que nossa pergunta de pesquisa é delineada. Buscamos, dessa forma, responder "De que forma, a partir de nossa reflexão teórica, podemos criar novas categorias que permitam olhar analogias utilizadas pelos professores de física do Ensino Médio em aulas de temas de física quântica ?". Assim, nosso objetivo é criar um quadro teórico que nos permita analisar o uso das analogias em três dimensões: epistemológica, cognitiva e educacional. Cada uma destas ênfases serão apresentadas e discutidas ao longo dos capítulos que compõem a tese.

\subsection{A estrutura geral da tese}

A fim de dar ao leitor um panorama geral, apresentamos nesta seção questões fundamentais de cada capítulo da tese. O capítulo a seguir busca reforçar as discussões aqui iniciadas na busca de uma revisão na literatura, a fim de localizar nosso problema de pesquisa no conjunto de trabalhos que consideramos possuir interlocução com o nosso. Basicamente trataremos neste capítulo de duas questões presentes na literatura especializada em ensino de ciências: o uso de analogias em aulas de ciências e a inserção de tópicos de FMC na educação básica.

Os três capítulos seguintes correspondem às três vertentes a partir das quais olhamos o conceito de analogia. No capítulo 3, apresentamos a analogia como elemento fundamental na formação de conceitos. A partir de nosso referencial teórico da psicologia cognitiva, a analogia é incorporada ao mecanismo do pensamento humano. É a partir do processo dialético de categorização-e-analogia que os conceitos são formados na estrutura cognitiva do sujeito. Este processo, ao contrário do processo de categorização estático e definitivo, presente em algumas perspectivas da psicologia tradicional, constitui-se num processo dinâmico e permanente. Tal perspectiva busca dar conta de compreender a formação de 
conceitos ordinários como o conceito de "mamãe" para uma criança que se encontra na fase inicial de apropriação da língua (linguagem), assim como se propõe a compreender os processos de criação mais complexos presentes, inclusive, na ciência.

No capítulo 4, buscamos olhar as analogias na produção do conhecimento científico. Inicialmente, discutimos que a concepção de ciência adotada pode a priori rejeitar a presença de analogia nas atividades a ela ligadas. Afinal, uma concepção de ciência que reforça que o pensamento científico deve seguir o rigor dedutivo, e que atribui às analogias alto grau de subjetividade, pertencendo esta última ao senso comum e evocando, por conseguinte, tudo que é contrário à ciência, tende imediatamente a se opor ao uso de analogias em suas atividades. Mais ainda, estas seriam incompatíveis ao desenvolvimento do conhecimento científico e por isso deveriam ser evitadas. Ainda no mesmo capítulo, apresentamos os níveis da analogias sugeridos por Poincaré. Segundo o matemático e filósofo francês, as analogias figurativas são usadas em atividades ordinárias, enquanto as analogias mecânicas já estão presentes, em certo nível, na elaboração do conhecimento científico. No entanto, como estas ainda se encontram na relação entre particulares, e não se pode pensar em ciência sem a capacidade de generalização, as analogias mecânicas não se constituem como elementos da elaboração de teorias no senso mais forte. São as analogias matemáticas que são capazes, pelo princípio da recorrência, de generalizar e, com isso, de criar o novo. Por último, buscamos, na concepção de Paty a respeito da mudança do status do senso comum, pensar na possibilidade de propor atividades no sentido de aceder a "níveis do senso comum" que possibilitem o uso de analogias matemáticas adequadas à formação de conceitos da física quântica.

O capítulo 5 é dedicado à dimensão didática das analogias. Buscamos apresentar nesse capítulo metodologias que são, de certa forma, consolidadas na literatura especializada em ensino de ciências. A partir de alguns trabalhos, apontamos para a necessidade de se incorporar na formação dos professores, inicial ou continuada, elementos de reflexão a respeito de atividades didáticas que lançam mão do uso de analogias. Dá-se destaque às categorias presentes no trabalho de CURTIS e REIGELUTH (1984), aos passos e cuidados no uso de analogias presentes na ideia do Teaching With Analogies (TWA) em GLYNN et al. (1994), e ao 
trabalho de VENVILLE (2008), intitulado "The Focus-Action-Refletion (FAR) Guide Science Teaching Analogies".

No capítulo 6 apresentamos a metodologia de pesquisa utilizada. Caracterizamos nossa pesquisa como qualitativa, mostramos de que forma esta foi influenciada e se comprometeu com nossos referenciais teóricos e descrevemos em seguida o contexto empírico. Descrevemos detalhadamente nossa estrutura de análise e assim apresentamos os três conjuntos de categorias que foram usados em nosso ensaio empírico. Apresentamos a construção de nossos mapas de eventos e, em seguida, definimos nossa unidade de análise a partir dos episódios.

Tendo em mãos a estrutura metodológica desenvolvida no capítulo anterior, no capítulo 7 apresentamos nosso ensaio empírico. Para isso, contamos com a construção de oito episódios provenientes do conjunto de aulas de quatro professores da rede estadual e privada do estado de São Paulo, que foram videografadas entre os anos de 2011 e 2012. Os temas das aulas analisadas foram: modelos atômicos, o efeito fotoelétrico, a dualidade onda partícula e algumas interpretações da mecânica quântica. A partir das categorizações dos episódios analisados, fizemos algumas considerações baseadas em nossas reflexões teóricas.

Por último, o capítulo 8 foi dedicado a algumas considerações a respeito da tese, destacando suas potencialidades e limitações. Fundamentalmente, apontamos para possíveis desdobramentos de nossa pesquisa, particularmente na apropriação do conceito de analogias matemáticas de Poincaré e da possibilidade de desenvolvimento de atividades didáticas, tendo em vista a ideia de mudança do status do senso comum dos alunos, a fim de aproximá-los dos conceitos da física quântica. 
CAPÍTULO 2 


\section{REVISÃO DA LITERATURA}

(...) A física também é cultura. A física também tem seu romance intrincado e misterioso. Isto não significa a substituição da física escolar "formulista" por uma física "romanceada". O que desejo é fornecer substância cultural para esses cálculos, para que essas fórmulas ganhem realidade científica e que se compreenda a interligação da física com a vida intelectual e social em geral.

(...)A ausência da física moderna em nossos cursos introdutórios é uma medida do nosso fracasso... O conteúdo básico da física introdutória tem permanecido essencialmente o mesmo por décadas. (...) O conteúdo de nossos cursos é, como tem sido por cerca de um século, mecânica, calor e termodinâmica, eletricidade e magnetismo, e ótica. (Zanetic, 1989, p.5 e 16) 
De forma a reforçar a pertinência do tema tratado na presente tese, buscamos neste capítulo apresentar uma revisão da literatura, basicamente, em dois eixos. Discutiremos a inserção de tópicos de FMC na educação básica e apresentaremos e debateremos o uso de analogias em atividades didáticas voltadas ao ensino de ciências.

\subsection{A Física Moderna e Contemporânea nos currículos da educação básica}

Conforme apresentamos na introdução da presente tese, há algumas décadas que discussões a respeito da atualização dos currículos de física estão presentes na literatura da área de ensino de física. Muitos e diversos são os argumentos que justificam a inserção de temas da física desenvolvida no século XX nos currículos do ensino médio. Um dos argumentos presentes em diversos trabalhos está relacionado à importância do conhecimento de conceitos relacionados à FMC na formação do cidadão contemporâneo, sem os quais os sujeitos não seriam capazes de entender nem agir de forma consciente nas relações do mundo. Para Terrazan (1992), tais argumentos já seriam suficientes para debatermos e buscarmos formas de introduzir conceitos da física moderna na educação básica.

Aparelhos e artefatos atuais, bem como fenômenos cotidianos em uma quantidade muito grande, somente são compreendidos se alguns conceitos estabelecidos a partir da virada deste século forem utilizados. A influência crescente dos conteúdos de Física Moderna e Contemporânea para o entendimento do mundo criado pelo homem atual, bem como a inserção consciente, participativa e modificadora do cidadão neste mesmo mundo, define, por si só, a necessidade de debatermos e estabelecermos as formas de abordar tais conteúdos na escola de $2^{\circ}$ grau. (TERRAZAN, 1992, p.210)

Lobato e Greca (2005) reafirmam que, entre os físicos e os professores de física, em nível internacional, há certo consenso sobre a necessidade de se incorporarem conteúdos de FMC nos currículos de física do ensino médio. Acrescentamos a este grupo os pesquisadores da área de ensino de física, tendo em vista a quantidade trabalhos que tratam do referido tema nas últimas décadas. 
As autoras destacam que, apesar das dificuldades de abordagem dos conceitos relacionados à física do século $X X$ no nível do ensino médio, estas não devem ser tomadas como elemento desmotivador. Ao contrário, na busca de incorporar tais conceitos, deve-se despender esforços a fim de superá-las. Para Lobato e Greca (idem), incorporar as discussões provenientes dos conceitos, leis e teorias da Física do século XX, em particular da Teoria Quântica (TQ), é entender e poder agir no mundo sob novas perspectivas.

\begin{abstract}
Embora a descrição dos fenômenos não seja fácil para alunos tão jovens ou que pertençam a carreiras não científicas, a opção não deve ser a exclusão de tópicos tão importantes e populares. É, pois, necessário que se estude como introduzir, no ES, os conceitos, leis e teorias da Física do Século XX, em particular a Teoria Quântica (TQ), que tem condicionado, fortemente, a investigação científica e tecnológica moderna e que, no século passado, revolucionou o pensamento humano. Conceitos bem estruturados na nossa cultura como o de localidade, trajetória ou determinismo tiveram de ser revistos. O próprio processo de fazer ciência, a relação entre teoria e experimentação, o papel do observador e do instrumento de observação adquiriram novas perspectivas. (LOBATO e GRECA, 2005, p.119)
\end{abstract}

Em consonância com esta perspectiva, a presente tese reafirma sua pertinência na medida em que buscamos entender o papel das analogias na comunicação de conceitos ligados à Física Quântica (FQ). Nosso esforço se dá no sentido de superar algumas contradições, dentre elas a de encontrar formas de representação dos conceitos quânticos que não sejam somente o formalismo matemático, caso contrário, tais conceitos não seriam acessíveis aos alunos do ensino médio, que não dispõem ainda de ferramentas matemáticas sofisticadas.

Em seu trabalho, Greca (2000) faz um levantamento das concepções dos alunos da educação básica a respeito de conceitos como quantização, dualidade onda-partícula, estabilidade do átomo, princípio da incerteza, fótons e elétrons. Segundo a autora, apesar de perceber que temas ligados à FQ são fascinantes, não são poucas as concepções equivocadas a respeito dos conceitos ligados aos temas supracitados. Tal constatação poderia, em princípio, indicar que não seria adequado trabalhar os conceitos da TQ no referido nível educacional, afinal não seria razoável reforçar concepções intuitivas a respeito dos conceitos quânticos. Ao contrário do 
que esperamos da introdução de temas da FMC, a compreensão errônea destes conceitos não contribuem para a formação do cidadão contemporâneo, e tampouco dá ao sujeito a capacidade de entender as suas ações no mundo sob novas perspectivas. No entanto, Greca (idem) destaca que pesquisas parecem mostrar que, se conceitos da Mecânica Quântica (MQ) não são discutidos em cursos introdutórios de Física, os alunos não conseguem superar as dificuldades iniciais ao chegarem aos cursos avançados. Isso parece reforçar a importância de se introduzir conceitos da TQ o mais cedo possível, afinal a autora destaca como resultado de suas pesquisas que o mais importante não é exatamente quando tais conceitos são apresentados, mas como são apresentados, o que, ao nosso ver, corrobora a perspectiva de apresentar os conceitos da TQ o mais cedo possível, quiçá no ensino médio.

Alguns autores propõem um levantamento bibliográfico mais apurado a respeito da FMC no ensino médio (Ostermann e Moreira, 2000; Greca e Moreira, 2001; Pereira e Ostermann, 2009; Silva e Almeida 2011), a partir do qual destacamse inúmeros trabalhos que reforçam o interesse e a preocupação da comunidade científica em incorporar as discussões referentes à Física do século XX no currículo da educação básica. Ostermann e Moreira (2000) mostram a amplitude no "tempo" e no "espaço" de pesquisas ligadas ao referido tema. Os autores resgatam reflexões do final da década de 70 que buscam discutir a importância de se trabalhar temas de FMC no ensino médio. A amplitude no espaço diz respeito a trabalhos que perpassam o continente americano e europeu, indicando, assim, certo grau de "universalidade" da preocupação aqui destacada. Ostermann e Moreira (ibidem) apresentam seis categorias nas quais os trabalhos por eles levantados foram classificados: (1) justificativas para a inserção de Física Moderna e Contemporânea (FMC) no ensino médio; (2) questões metodológicas, epistemológicas, históricas referentes ao ensino de FMC; estratégias de ensino e currículos; (3) concepções alternativas dos estudantes acerca de tópicos de FMC; (4) temas de FMC apresentados como divulgação ou como bibliografia de consulta para professores de nível médio; (5) propostas testadas em sala de aula com apresentação de resultados de aprendizagem; (6) livros didáticos de nível médio que inserem temas de FMC.

Greca e Moreira (2001) também propõem uma revisão na literatura, dessa vez relativa ao ensino da $\mathrm{MQ}$ como curso introdutório, tanto no ensino médio, como 
em cursos universitários e na formação de professores. Os autores classificam os trabalhos em três grandes grupos, a saber, artigos sobre concepções dos estudantes a respeito de conteúdos de Mecânica Quântica; trabalhos com críticas aos cursos introdutórios de Mecânica Quântica; e estudos contendo propostas de novas estratégias didáticas. Para eles, questões associadas ao ensino da $\mathrm{MQ}$ relacionadas a dificuldades de aprendizado, ou ao desenvolvimento de estratégias didáticas, se configuram como recentes na área de ensino de ciências, embora o referido tema tenha crescido nos últimos anos. Vale, no entanto, destacar que esta afirmação é datada de mais de uma década, o que, para os nossos dias, justifica acrescentar toda produção acadêmica aos quase quinze anos passados até hoje. Isso vai implicar o amadurecimento das questões e reflexões a respeito do tema, que é confirmado por levantamentos bibliográficos mais recentes (Pereira e Ostermann, 2009; Silva e Almeida 2011).

A partir de revisões bibliográficas mais recentes, uma datada de 2009 e outra de 2011, pretendemos reafirmar a pertinência do tema na literatura. As quatro revisões aqui destacadas podem ser vistas como complementares, e sua apresentação na presente tese tem por objetivo reforçar nossa contribuição ao conjunto de pesquisas desenvolvidas ao longo das últimas décadas. Pereira e Ostermann (2009) propõem um levantamento bibliográfico recente, tendo em conta o vasto trabalho feito pela autora em 2000, assim como o levantamento realizado por Greca e Moreira (ibidem). Eles consideram consistentes ambos os trabalhos e realizam uma atualização da bibliografia associada ao tema, presente na literatura em ensino de ciências. Em seu trabalho, foi realizado um levantamento de artigos sobre o ensino de FMC publicados nas principais revistas de ensino de ciências do Brasil, assim como do exterior, no período de 2001 a 2006, a partir do qual os autores catalogaram 102 trabalhos. Os artigos analisados foram classificados em quatro grandes categorias: propostas didáticas testadas em sala de aula; levantamento de concepções; bibliografia de consulta para professores; e análise curricular.

Na primeira categoria, incluem-se trabalhos voltados a inovações didáticas e resultados de experiências de FMC no ensino. O levantamento bibliográfico aqui analisado apresenta cinco subcategorias dentre as propostas didáticas testadas em sala de aula: 1) estratégia para abordar FMC no ensino médio; 2) mudanças no 
ensino de FMC em nível superior; 3) uso de tecnologias de informação e comunicação; 4) abordagem em ciência, tecnologia e sociedade; 5) articulação com a história e a filosofia das ciências. No entanto, como destacaram os autores, tais categorias e subcategorias não tiveram a pretensão do rigor de limites, afinal, como relatam Pereira e Ostermann (ibidem), alguns trabalhos foram classificados em mais de uma categoria. De fato, mais que categorizar rigorosamente os artigos analisados, pretendeu-se dar um panorama geral de trabalhos ligados ao tema, até o ano de 2006.

Destacamos alguns artigos pertencentes à primeira subcategoria a fim de reforçar a pertinência de trabalhos que buscam criar estratégias para a implementação de temas de FMC na educação básica. Tal reforço se evidencia pelo volume de artigos encontrados, assim como sua amplitude espacial, afinal não são poucos os trabalhos de experiências realizadas em outros países (Budde et al., 2002; Johansson et al., 2001; Kalkanis et al., 2002). Na verdade, com exceção da subcategoria 2, todas as demais incluem ações didáticas (que podem variar quanto às metodologia e abordagens) voltadas a alunos da educação básica, incluindo aqui experiências em classes do ensino fundamental. Em uma perspectiva de abordagem CTS (Ciência, Tecnologia e Sociedade), Samagaia e Peduzzi (2004) propõem um módulo didático voltado a temas de FMC dentro do contexto histórico do projeto Manhattan (1941-1945). Os autores lançam mão da técnica psicoterápica RPG (Roleplaying Game ou Jogo de Papéis), a partir da qual temas como fissão nuclear, bomba atômica, armas químicas e biológicas foram trabalhados com os alunos.

As demais categorias descritas por Pereira e Ostermann (ibidem) reúnem também uma quantidade considerável de artigos. Não restrita ao período do presente levantamento bibliográfico, não são poucas as pesquisas que buscam levantar as concepções de alunos e professores acerca de temas específicos de FMC. Estas buscam avaliar dificuldades, concepções prévias, perfis conceituais, modelos mentais, interpretações, entre outras questões associadas (Arriassecq e Greca, 2004; Montenegro e Pessoa Jr. 2002; Ostermann e Ricci 2004a; Paulo e Moreira 2004). Para a categoria "bibliografia de consulta para professores", os autores atribuíram quatro subcategorias relacionadas ao tipo de produção acadêmica: 1) textos didáticos; 2) novos recursos didáticos; 3) novas propostas e estratégias didáticas; 4) divulgação científica. Os trabalhos aqui classificados não 
foram necessariamente aplicados e avaliados enquanto ferramenta de aprendizagem de temas de FMC. Antes, porém, estes artigos se apresentam como elementos de suporte para os professores. Destacamos um dentre os trabalhos analisados pelos autores, a saber, o software desenvolvido por Ostermann et al. (2006), o qual simula o interferômetro de Mach-Zehnder. O simulador pode operar em regime monofotônico, que permite discussões a respeito do caráter quântico dos objetos microscópicos. Tal destaque se deve ao fato de que dois dos professores cujas aulas foram analisadas em nosso ensaio empírico lançam mão, em suas aulas com alunos do ensino médio, do referido software, a fim de potencializar as discussões a respeito de quatro interpretações da $M Q$. Finalmente, trabalhos que apresentam inovações curriculares mostram que esta iniciativa não é restrita ao Brasil. Lobato e Greca (2005) fazem um levantamento de programas curriculares em outros países que contemplam temas de FMC, dentre os quais destacamos Portugal, Espanha, França, Reino Unido, Dinamarca, Suécia, Canadá, Austrália, Itália e Finlândia. Além de reforçar certa tendência "mundial" de movimentos de reformulação curricular com o intuito de incluir a física do século $X X$ na educação básica, estes também destacam alguns tópicos de FMC mais abordados, dentre os quais citamos: os modelos atômicos, o efeito fotoelétrico, quantização e a constante de Planck, teoria da relatividade restrita, física de partículas, dualidade ondapartícula e física nuclear. Ressaltamos que, nesta última categoria, também foram incluídos artigos que abordaram temas de FMC nos livros didáticos e revisões bibliográficas.

Silva e Almeida (2011) propõem um levantamento bibliográfico mais recente e mais específico. Os autores realizam uma revisão dos principais periódicos da área de Ensino de Ciências (em particular do Ensino de Física), todos eles em versão eletrônica, publicados desde seu primeiro número até agosto de 2010 . A especificidade se dá na medida em que, enquanto os artigos de Ostermann e Moreira (2000) e Pereira e Ostermann (2009) fazem um levantamento de pesquisas ligadas a temas de FMC e o artigo de Greca e Moreira (2001) trata do tema da MQ nos níveis médio e universitário, Silva e Almeida (ibidem) se concentram em trabalhos associados a temas de FQ no ensino médio. Como resultado da busca, os referidos autores catalogaram 23 artigos relacionados ao tema distribuídos entre periódicos nacionais e internacionais, entre os anos de 1997 e 2009. 
Quadro 2.1- Artigos de periódicos analisados no período de 1997 a 2009.

\begin{tabular}{|c|c|c|}
\hline $\begin{array}{c}\text { Ano de } \\
\text { publicação }\end{array}$ & Periódico & $\begin{array}{c}\text { Total de } \\
\text { publicações } \\
\text { no período }\end{array}$ \\
\hline 1997 & Physics Education & 1 \\
\hline 1998 & - & - \\
\hline 1999 & $\begin{array}{c}\text { Physics Education ; Caderno } \\
\text { Brasileiro/Catarinense de Ensino de Física }\end{array}$ & 2 \\
\hline 2000 & Investigações em Ensino de Ciências & 1 \\
\hline 2001 & Investigações em Ensino de Ciências & 1 \\
\hline 2002 & International Journal of Science Education & 1 \\
\hline 2003 & - & - \\
\hline 2004 & $\begin{array}{c}\text { Revista Brasileira de Pesquisa em Educação em } \\
\text { Ciências }\end{array}$ & 1 \\
\hline 2005 & $\begin{array}{c}\text { Ciência \& Educação ; Investigações em Ensino de } \\
\text { Ciências }\end{array}$ & 2 \\
\hline 2006 & & - \\
\hline 2007 & $\begin{array}{c}\text { A física na escola ; Caderno Brasileiro/Catarinense } \\
\text { de Ensino de Física; Science \& Education }\end{array}$ & 4 \\
\hline 2008 & $\begin{array}{c}\text { Physics Education ; Revista Brasileira de Ensino } \\
\text { de Física ; Revista Electrónica de Investigación } \\
\text { en Educación en Ciencias }\end{array}$ & 3 \\
\hline 2009 & $\begin{array}{l}\text { Ciência \& Educação ; Investigações em Ensino de } \\
\text { Ciências; Revista Brasileira de Pesquisa em } \\
\text { Educação em Ciências; Revista Electrónica de } \\
\text { Enseñanza de las Ciências; Revista Electrónica de } \\
\text { Investigación en Educación en Ciencias }\end{array}$ & 7 \\
\hline $\begin{array}{l}\text { De } 1997 \text { a } \\
2009\end{array}$ & & 23 \\
\hline
\end{tabular}

O Quadro 2.1 destaca os periódicos relacionados no referido levantamento bibliográfico no período descrito. Destacamos que, dos 23 trabalhos encontrados no presente levantamento bibliográfico, 15 são referentes a artigos publicados em periódicos nacionais, o que corresponde a cerca 65\% dos artigos analisados. No entanto, ressaltamos que dois dos artigos publicados em periódicos nacionais têm autores argentinos (Fanaro et al., 2009a ; Fanaro et al., 2009b) e um artigo publicado em um periódico internacional corresponde a uma autora brasileira e colaboradores (Ostermann et al., 2009). Ainda assim, o número de artigos nacionais é significativo diante dos dados aqui apresentados. 
Quadro 2.2- As categorias e os artigos relacionados.

\begin{tabular}{|c|c|c|}
\hline Categoria dos artigos & $\begin{array}{l}\text { Quantidade } \\
\text { de } \\
\text { publicações }\end{array}$ & Artigos \\
\hline $\begin{array}{c}\text { Revisão da literatura sobre o } \\
\text { ensino de FQ/FMC }\end{array}$ & 3 & $\begin{array}{c}\text { Ostermann e Moreira (2000) } \\
\text { Greca e Moreira (2001) } \\
\text { Pereira e Ostermann }\end{array}$ \\
\hline Análise curricular & 2 & $\begin{array}{l}\text { Lobato e Greca (2005) } \\
\text { Brockington e Pietrocola (2005) }\end{array}$ \\
\hline $\begin{array}{c}\text { Análise de conteúdos de } \\
\text { FQ/FMC presentes em livros } \\
\text { didáticos }\end{array}$ & 1 & Velentzas et al. (2007) \\
\hline $\begin{array}{c}\text { Elaboração e/ou aplicação de } \\
\text { proposta de ensino }\end{array}$ & 16 & $\begin{array}{c}\text { Cuppari et al. (1997) } \\
\text { Pospiech (1999) } \\
\text { Pinto e Zanetic (1999) } \\
\text { Oslen (2002) } \\
\text { Paulo e Moreira (2004) } \\
\text { Costa et al. (2007) } \\
\text { Andrade et al. (2007) } \\
\text { Fanaro et al. (2007) } \\
\text { Johansson e Milstead (2008) } \\
\text { Sales et al. (2008) } \\
\text { Arlego (2008) } \\
\text { Otero et al. (2009) } \\
\text { Carvalho Neto et al. (2009) } \\
\text { Fanaro et al. (2009a) } \\
\text { Fanaro et al. (2009b) } \\
\text { Ostermann et al. (2009) }\end{array}$ \\
\hline $\begin{array}{l}\text { Concepções dos professores a } \\
\text { respeito do ensino de FQ/ } \\
\text { FMC no ensino médio }\end{array}$ & 1 & Monteiro et al. (2009) \\
\hline
\end{tabular}

Assim como nos demais levantamentos bibliográficos apresentados na presente tese, encontramos neste uma proposta de categorização dos trabalhos analisados. Para Silva e Almeida (ibidem), são 5 os grupos de categorias a partir dos 
quais podemos analisar os artigos selecionados: (1) Revisão da literatura sobre o ensino de FQ/FMC; (2) Análise curricular; (3) Análise de conteúdos de FQ/FMC presentes em livros didáticos; (4) Elaboração e/ou aplicação de proposta de ensino; (5) Concepções dos professores a respeito do ensino de FQ/ FMC no ensino médio.

O Quadro 2.2 exibe a distribuição dos artigos analisados no presente levantamento bibliográfico nas categorias supracitadas. Dá-se destaque à categoria 4 , referente à elaboração e/ou aplicação de propostas de ensino. Diferentemente do levantamento apresentado em Pereira e Ostermann (2009), no qual os autores distinguem trabalhos classificados como de consulta para professores (textos didáticos; novos recursos didáticos; novas propostas e estratégias didáticas; divulgação científica) daqueles que apresentam algum resultado de experiência (como propostas didáticas testadas em sala de aula, levantamento de concepções e análise curricular), o levantamento bibliográfico em questão classifica em um único grupo de categoria as propostas de ensino, quer sejam de elaboração ou de aplicação. Sendo assim, a maior parte dos artigos encontrados foram classificados nesta categoria (quase $70 \%$ ).

Nossa intenção não é avaliar a qualidade dos artigos aqui apresentados, antes, porém, pretendemos apresentar um panorama geral dos trabalhos presentes na literatura do ensino de ciências, cujas abordagens fossem o ensino de temas de FMC, fundamentalmente na educação básica. Os quatro levantamentos bibliográficos aqui apresentados nos permitem constatar a relevância do tema para a área de pesquisa em ensino. Diversos trabalhos distribuídos em algumas categorias mostram a tendência de se criarem elementos que possibilitem efetivamente a inclusão de temas relacionados à física do século XX.

Mesmo com quantidade significativa de trabalhos presentes na literatura relativos ao ensino de temas de $F M C$, julgamos que questões relacionadas às particularidades dos conceitos do "novo" domínio da física ainda precisam ser incansavelmente debatidas. A partir desta perspectiva, a presente tese se propõe como espaço de reflexão a respeito dos conceitos quânticos que podem ser trabalhados com alunos da educação básica. Como destacamos anteriormente, é fundamental que levemos em consideração as contradições presentes nas ações de ensino de conceitos que a priori não podem ser representados, ou ao menos não 
com as ferramentas de representação da nossa realidade sensível. É bem verdade que propostas didáticas de implementação dos referidos temas são fundamentais e indispensáveis. No entanto, como destacam Pereira e Ostermann (ibidem), é preciso também se investir em pesquisas que sejam submetidas a avaliações críticas, de forma a levar em conta questões relativas à aprendizagem dos "novos" conceitos apresentados aos alunos da educação básica.

É possível constatar que, apesar do notável aumento relativo de publicações sobre o ensino de FMC que apresentam resultados de pesquisa, a maioria dos artigos ainda se refere a bibliografia de consulta para professores. Embora os trabalhos de desenvolvimentos sejam extremamente relevantes para o ensino de ciências, pois são fontes de informação e recursos para professores e alunos, é necessário que o material resultante desses trabalhos seja submetido a uma avaliação crítica para verificar em que medida eles realmente facilitam os processos de ensinoaprendizagem.(Pereira e Ostermann, 2009, p.141)

Dessa forma, apesar de não ser classificada diretamente em nenhuma das categorias apresentadas pelos levantamentos bibliográficos aqui apresentados, por não se configurar nem como bibliografia de consulta para professores, tampouco como resultado de pesquisa na perspectiva apresentada pelos autores, a presente tese se apresenta como elemento inovador e fundamental para ações que busquem introduzir temas de $\mathrm{FQ}$ no ensino médio. Afinal, pretendemos analisar uma ferramenta básica e sempre presente nas ações comunicativas, a saber, as analogias, de forma a avaliar sua pertinência em ações didáticas voltadas ao ensino de FQ. Sobretudo, a partir de nossos referenciais teóricos, como apontado anteriormente, iremos propor certa tipologia do uso de analogias em atividades de ensino. 


\subsection{Analogias como ferramentas em atividades didáticas}

O uso de analogias e metáforas com o intuito de apresentar algo novo tem sido empregado desde tempos remotos ${ }^{4}$. No entanto, tal uso não está restrito a esse objetivo. Muitas vezes, utilizamos metáforas a fim de trazer uma mensagem de forma poética ou, por motivos variados, para não nos comprometermos com a mensagem em si. Um exemplo disso foi o que ocorreu durante o período de ditadura militar no Brasil. Esse período assolou nosso país, intensificando-se após a publicação do Ato Institucional $N^{0} 5$ (Al-5), que garantia totais poderes ao governo militar e restringia absurdamente os direitos dos cidadãos. Nesse período, os artistas tiveram de cuidar do conteúdo de suas obras, pois qualquer ideia que pudesse ser interpretada como contrária à ideologia dos militares era alvo de repressão. Por conta disso, alguns cantores, atores, escritores e jornalistas, quando não eram exilados, eram perseguidos, presos, sequestrados e torturados.

$\mathrm{Na}$ tentativa de conseguir divulgar seus trabalhos, os artistas lançaram mão do uso de metáforas nas composições de músicas e na elaboração dos roteiros de peças teatrais. Essa foi uma maneira que os compositores, cantores e escritores encontraram para tentar "driblar" a censura e assim fugir das sanções dos militares. Um exemplo disso é a musica Apesar de Você, de Chico Buarque. Lançada em 1970, a composição, que trata aparentemente de uma discussão entre namorados, pode ser interpretada como uma mensagem ao presidente Médici: "Você vai pagar e é dobrado / cada lágrima rolada /nesse meu penar / apesar de você / amanhã há de ser / outro dia / você vai se dar mal' (BUARQUE, 2013).

Apesar de reconhecer diversas atividades humanas nas quais o uso de analogias e metáforas estejam presentes, o foco de nossa pesquisa se dá no uso de metáforas e analogias em atividades de ensino, particularmente em aulas de Ciências. A relevância do uso de analogias para a pesquisa em ensino de ciências, sob diversos aspectos, tem sido apontada com bastante frequência na literatura especializada da área.

\footnotetext{
${ }^{4}$ A Bíblia, por exemplo, tem diversos trechos do evangelho de Cristo no qual o líder religioso utiliza metáforas e analogias a fim de comunicar ao povo sua mensagem. ("O Reino dos céus é como o fermento que uma mulher tomou e misturou com uma grande quantidade de farinha e toda a massa ficou fermentada" [Mateus 13:33] ).
} 
Encontramos na literatura das últimas décadas pesquisas que buscam explorar a utilização de representações no ensino de ciências (AINSWORTH, 1999; NETO, 2009). Há também trabalhos a respeito do uso de analogias no ensino de Ciências, que destacam a atenção que deve ser dada às escolhas feitas, para que seu uso não traga mais problemas que elementos facilitadores à compreensão dos conceitos relacionados à referida atividade de ensino (e.g, AUBUSSON et all, 2006; SOUZA, 2006; VILLANI et al., 1997).

A destacar, no capítulo 12 do Second International Handbook of Science Education intitulado "Aprendendo a partir e por meio de representações" (WALDRIP e PRAIN, 2012), encontramos um levantamento de pesquisas a respeito do tema realizadas nos últimos 15 anos. Tais pesquisas buscam entender como as representações utilizadas no ensino podem contribuir de forma apropriada para a construção de "significados", e quais são as limitações e problemas associados ao seu uso.

Segundo Ainsworth (1999), para que o alunos aprendam conceitos científicos a partir da utilização de múltiplas representações, é necessário que estes: (a) compreendam os códigos e significados de uma representação, (b) entendam as relações entre representação e objetivos conceituais ou processos, (c) traduzam ${ }^{5}$ características-chave dos conceitos envolvidos nas representações e (d) saibam quais características devem ser enfatizadas na elaboração ou escolha de suas representações.

Waldrip e Prain (2012) apontam como pertinente o investimento em pesquisas relacionadas ao uso de representações nos diversos quadros teóricos, incluindo a semiótica, a ciência cognitiva, perspectivas sócio-históricas, teorias pedagógicas e de neurociência, direcionados à cognição, a dimensões estratégicas de metacognição da aprendizagem. Waldrip e Prain (ibidem) também destacam a importância da análise de aspectos estéticos, retóricos e afetivos das respostas dos alunos. Nesta perspectiva, há incentivo para a investigação focada em estudo de casos do uso de representações associados a temas específicos da ciência (AINSWORTH, 2008; CAROLAN et al., 2008).

\footnotetext{
${ }^{5}$ Nesse contexto "traduzir" tem o sentido de ser capaz de reconhecer as relações conceituais entre as representações ou entre padrões conceituais invariantes através das representações.
} 
O Quadro 2.3 mostra o resultado do levantamento bibliométrico realizado por nós, a partir do qual identificamos trabalhos dos últimos 20 anos relacionados ao uso de analogias em atividades de ensino de ciências, presentes em periódicos nacionais e internacionais da área de ensino de ciências. Para isso, em nosso levantamento na literatura internacional, utilizamos o buscador Eric (Education Resources Information Center), assim como o Springerlink. As palavras utilizadas nas buscas foram: analogies and science. Analisamos aproximadamente 500 abstracts, dentre os quais selecionamos 77 , tendo como critério a relevância do tema uso de analogias em aulas de ciências. No entanto, dentre trabalhos que tratavam de um tópico especifico, foram considerados majoritariamente aqueles relacionados a conteúdos de física.

Já para os trabalhos de revistas nacionais acessamos diretamente o site de cada revista [Caderno Brasileiro de Ensino de Física (CBEF); Revista Brasileira de Ensino de Física (RBEF); Revista Brasileira de Pesquisa em Ensino de Ciências (RBPEC); Revista Ciência \& Educação (RC\&E) e Revista Investigação em Ensino de Ciências (RIENCI)]. A escolha das revistas nacionais teve como base a relevância dos periódicos, seu reconhecimento de acordo com órgãos oficiais e segundo classificação da Coordenação de Aperfeiçoamento de Pessoal de Nível Superior (CAPES).

A seleção das revistas internacionais seguiu critérios semelhantes aos das revistas nacionais. Dentre as publicações estrangeiras, destacamos os periódicos Science Education (SE); Science \& Education (S\&E) e International Journal of Science Education (IJSE). Destacamos também, em nosso levantamento, a revista Journal of Research in Science Teaching (JRST) devido ao número de artigos relacionados ao tema da presente pesquisa. Os demais periódicos que contribuíram com nosso levantamento, como, por exemplo, Physics Teacher, Physics Education, Enseñanza de las Ciências, dentre outros, foram classificadas no grupo de trabalhos denominado OUTROS. 
Quadro 2.3 - Tabela de trabalhos relacionados ao uso de representações no Ensino de Ciências e do uso de analogias de 1990 à 2012.

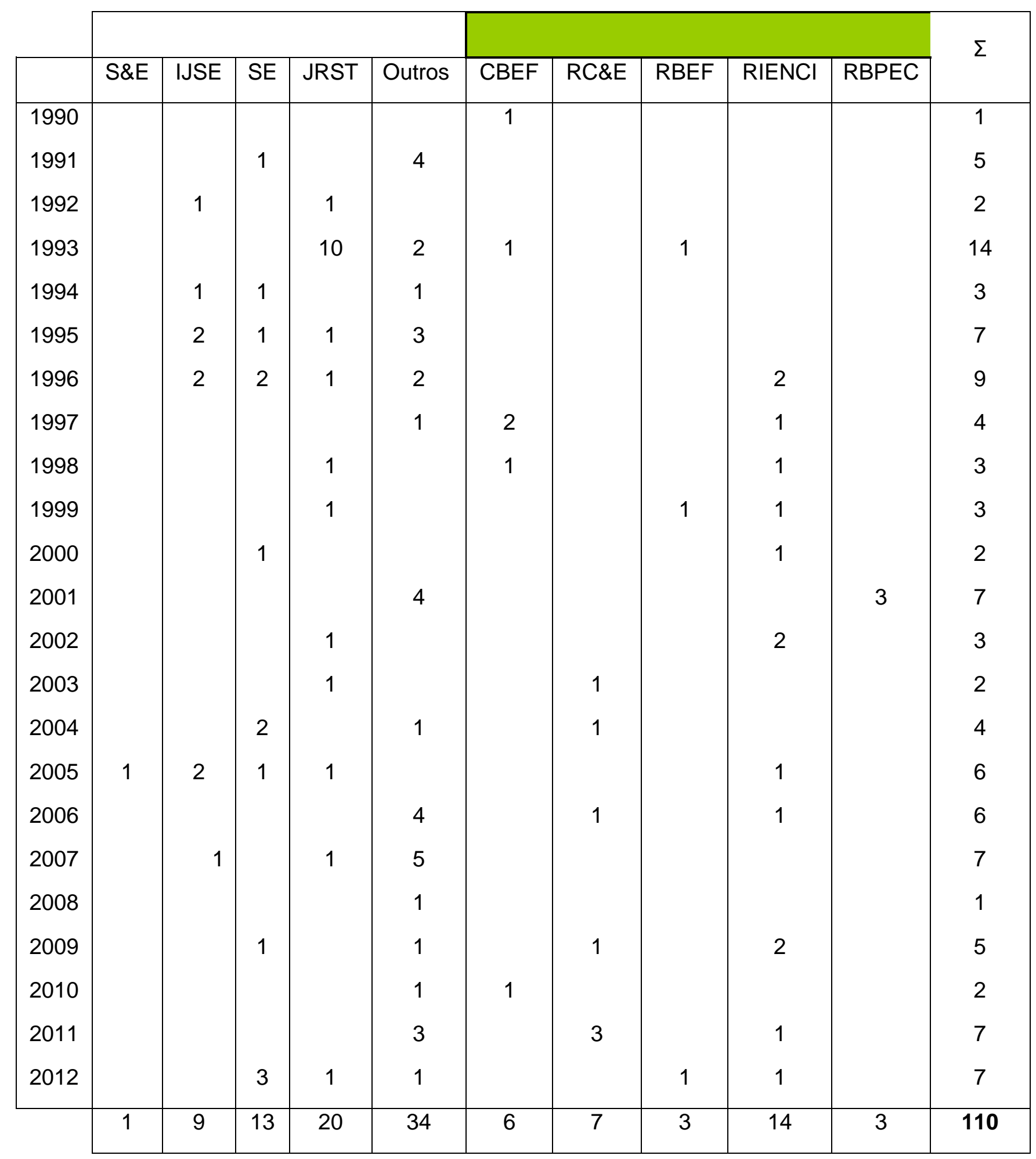


O Gráfico 1.1 foi construído na tentativa de melhor visualizar a distribuição dos trabalhos levantados e tabulados acima. Uma análise nos permite ver que, nos últimos 20 anos, o tema esteve presente com certa frequência na literatura especializada da área. Contudo, identificamos um pico na distribuição no ano de 1993. Isso se deve a um número temático sobre analogias da revista Journal of Research in Science Teaching, publicado no referido ano.

Destacamos que nosso levantamento teve como foco trabalhos relacionados ao uso de representações, analogias e metáforas nas aulas de ciências em geral, ou em temas específicos de Física. Não foram contabilizados artigos que tratassem de temas específicos de Química e/ou Biologia ${ }^{6}$.

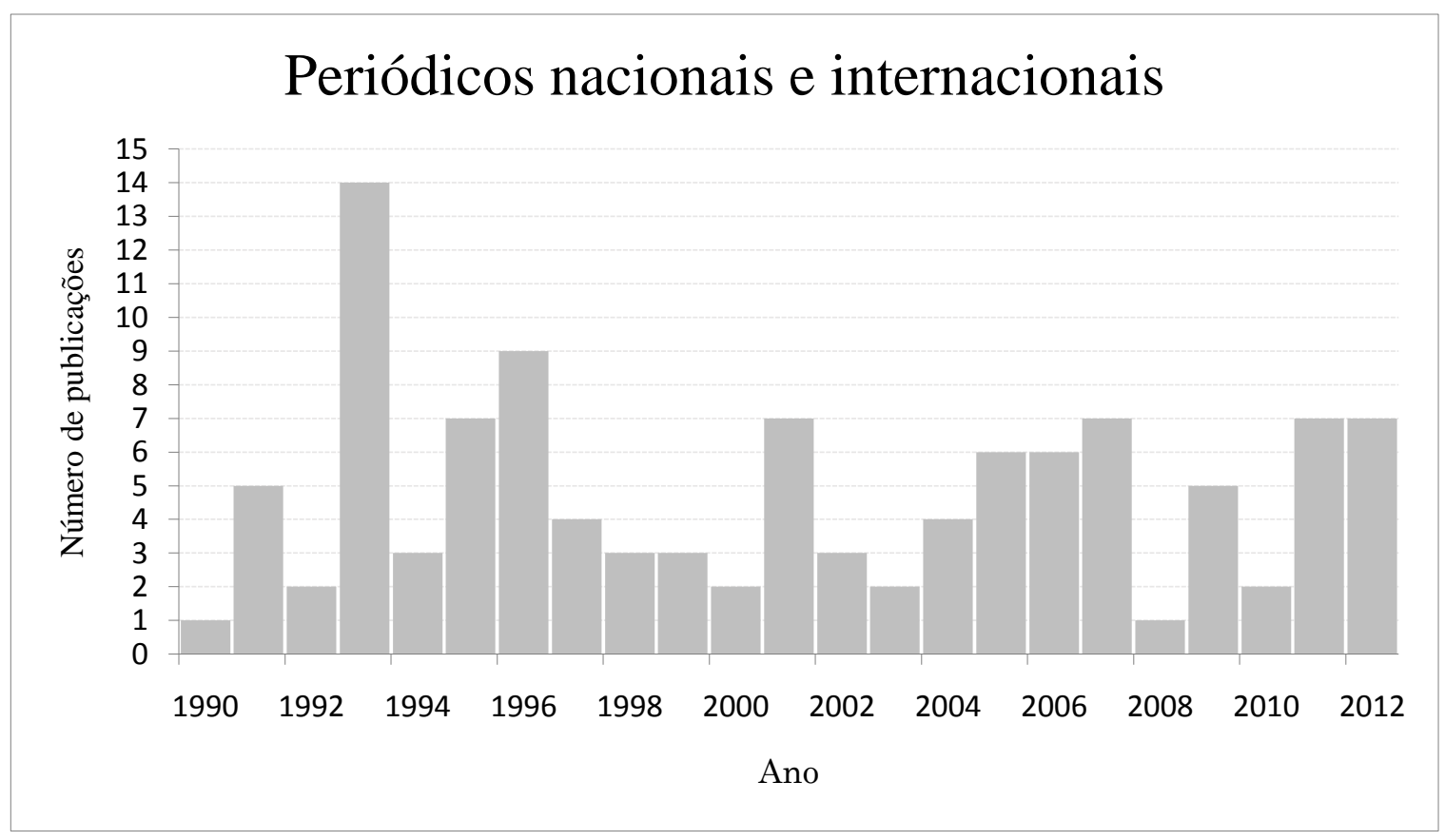

Gráfico 2.1 - gráfico de distribuição dos periódicos em revistas nacionais e internacionais desde 1990.

\footnotetext{
${ }^{6}$ Diferenciamos aulas de ciências em geral de temas específicos de Química e/ou Biologia da seguinte forma: artigos que tratavam do uso de analogias em aulas de ciências apontando questões gerais sem abordar um tema especifico foram contabilizados, assim como os artigos que tratavam do uso de analogias tomando um tema especifico da Física. No entanto, trabalhos que se baseavam em temas específicos de Química e/ou Biologia não foram considerados em nosso levantamento.
} 
Por meio da leitura dos resumos de alguns trabalhos e do texto completo dos demais, encontramos poucos que se apresentaram contrariamente ao uso de analogias e metáforas no ensino de ciências. Ao contrário, encontramos em grande parte deles sugestões do uso consciente para torná-lo efetivamente eficaz. Este direcionamento é relevante para esta pesquisa, pois, sendo nosso objetivo criar um quadro de análise para os usos de analogias por professores de física, buscamos justamente propor um instrumento que permita a tomada de consciência sobre como as mesmas são utilizadas em sala de aula.

Ressaltamos que, apesar de não fazer parte de nosso levantamento, buscamos trabalhos anteriores ao ano de 1990 e encontramos algumas controvérsias a respeito do tema. Fundamentalmente, na primeira metade dos anos 80 , aparecem alguns trabalhos que chamam a atenção para o não uso de analogias e metáforas em atividades de Ensino de Ciências ${ }^{7}$.

Segundo Duit (1991), alguns estudos sobre concepções alternativas mostram que é frequente $\mathrm{o}$ uso de analogias por parte dos alunos na tentativa de compreender novos fenômenos associados a áreas que lhes são familiares. $\mathrm{Na}$ verdade, os resultados de tais estudos não se apresentam como novidade, na medida em que entendemos o processo de relacionar conceitos através de analogias como atividade básica do pensamento humano.

Apesar de encontrarmos na literatura especializada da área um vasto conjunto de trabalhos referentes aos temas em questão, a saber, o uso de representações no Ensino de Ciências e suas implicações, o uso de metáforas e analogias no Ensino de Ciências e suas implicações, uma lacuna foi observada na literatura em relação a estudos que investigassem se há uma relação entre a concepção filosófica de ciência dos professores e os critérios de escolha e/ou uso de representações, analogias e metáforas em suas aulas, e se isso se dá de forma consciente e planejada. Nossa pesquisa se insere nesse contexto e busca trazer os estudos no campo da psicologia cognitiva e da epistemologia da física na tentativa de compreender as consequências do uso de analogias na construção da versão didatizada dos saberes escolares e sua influência na aprendizagem. Nossa

\footnotetext{
${ }^{7} \mathrm{Na}$ seção 2.2 levantamos, baseados na literatura especializada da área de Ensino de Ciências, alguns elementos que mostram as potencialidades e as dificuldades do uso de analogias em atividades de ensino.
} 
contribuição mais significativa se dá no sentido de pensar os aspectos de representação no ensino da física quântica, esperando, assim, que a aproximação de nossos referenciais da psicologia e da filosofia com as questões da aprendizagem traga elementos relevantes que possam ser agregados ao repertório de pesquisas relacionadas ao tema, em particular, na formação do professor.

O presente levantamento tem por objetivo oferecer também um panorama geral das pesquisas realizadas nas últimas duas décadas, a respeito do uso de representações em aulas de ciências. No capítulo 4, retomamos a discussão a respeito dos trabalhos relacionados ao uso de analogias em atividades didáticas na área de ciências, no entanto, dessa vez, de forma mais específica e detalhada. Selecionamos alguns artigos sob o critério de pertinência às reflexões que nortearam a presente tese, a fim de completar a tríade teórica de análise das analogias, a saber, a dimensão cognitiva, a dimensão epistemológica e a que destacamos aqui, a dimensão didática do uso de analogias. 
CAPÍTULO 3 


\section{ANALOGIAS E A FORMAÇÃO DE CONCEITOS}

(...) afinal uma palavra é uma etiqueta linguística que ganha forma de uma sequência sonora, de um conjunto de letras impressas ou de um pouco de linguagem interiorizada, enquanto que um conceito é uma representação cerebral abstrata, à qual por vezes uma única palavra esta relacionada, às vezes várias, e algumas vezes nenhuma.

(...) Nossa capacidade de
"analogização" permite estender a
categoria a entidades que
compartilham as mesmas
características profundas, mesmo se a descrição literal parece incompatível com a "etiqueta" da expressão: quando uma categoria está bem fundada, a "etiqueta" é apenas um vestígio que remonta à história de sua constituição mas que é incapaz de fixar seus limites. (Hofstadter e Sander, 2013,p.46 e 121) 
Nossa tese se apoia fundamentalmente em três pilares: 1) o papel das analogias na formação de conceitos gerais em nossa estrutura cognitiva; 2) o papel das analogias nas ciências, tanto na concepção de uma nova teoria quanto na sua comunicação entre seus pares, os cientistas; 3) o uso de analogias em atividades didáticas de ciências. Este capítulo é dedicado ao primeiro destes eixos, o uso de analogias ligado ao processo de categorização como um mecanismo de formação de conceitos, processo este que ocorre de forma dinâmica, incessante e incontrolável.

Como forma de organização do presente capítulo, primeiramente, apresentamos, segundo a perspectiva adotada, os conceitos de categoria e categorização e mostramos de que forma estes conceitos se diferenciam. Ainda na primeira parte deste capítulo, definimos analogia e explicamos o seu papel na formação de conceitos primordiais. Nosso principal objetivo nessa primeira parte do presente capítulo é apresentar o par dialético analogia-categorização e mostrar de que forma compreendemos que este seja o motor do pensamento humano. Para isso, além da descrição de cada um dos elementos supracitados, lançamos mão de alguns exemplos simples, a fim de tornar claro o papel do referido par dialético. $\mathrm{Na}$ tentativa de enriquecer nossa abordagem, num processo gradual de complexificação, propomos uma reflexão a respeito do processo de significação via analogia-categorização através de um movimento "ascendente", que vai das palavras à expressões cada vez mais complexas ou subjetivas.

Reforçando o objetivo da presente tese, em um segundo momento apresentamos a concepção de aprendizagem aqui adotada. Destacamos alguns elementos importantes presentes na psicologia de Vygotsky e propomos uma síntese desta com as principais ideias desenvolvidas neste capítulo.

Por fim, apontamos o sentido do uso de analogias presentes nas diversas atividades humanas, da mais simples comunicação entre pares a pensamentos sofisticados, pensamentos estes que culminam com o espírito criativo e têm como frutos as mais interessantes descobertas. 


\subsection{Analogia e o desenvolvimento de conceitos.}

O conceito de analogia está longe de ser consensual, ao contrário, diversas áreas do conhecimento têm se apropriado do termo e atribuído a este diferentes significados. Segundo Plantin (2011), do ponto de vista da antropologia, a analogia postula que as coisas, os seres, os eventos refletem uns nos outros. A partir desta afirmação, a função do pensamento analógico seria decifrar estas semelhanças. $O$ autor destaca que as analogias são frutíferas e estimulam a criatividade, a descoberta e a invenção, sendo assim importantes no ensino e na divulgação científica. No entanto, de acordo com Plantin (2011), ela representa um obstáculo epistemológico à medida que a explicação que propõe, extremamente satisfatória à intuição, cria barreiras a análises mais aprofundadas. ${ }^{8}$

No presente capítulo apresentamos, segundo a perspectiva adotada, o papel das analogias na formação dos conceitos. Nossa abordagem não se limita aos conceitos da ciência, mas antes apontamos para o uso constante de analogias na formação dos diversos conceitos ao longo da vida do sujeito, incluindo os conceitos científicos. Nossas considerações iniciais estão baseadas na psicologia cognitiva e na liguística. Dentre diversos trabalhos que contribuíram com nossa reflexão a respeito do tema, destacamos a obra "L'Analogie - Coeur de la pensée" de Hofstadter e Sander (2013), a partir da qual nossas considerações foram especialmente pautadas. De acordo com os autores, sem conceitos não se pode "falar" de pensamento e sem analogias não há formação de conceitos. Na verdade, esta é a "tese" defendida neste capítulo e a qual tentaremos explicitar. Segundo nossa perspectiva, destacamos a relação palavra-conceito, discutimos as categorias das palavras como resultado do complexo e dinâmico processo de categorização e apresentamos o papel das analogias nesse processo. Cada conceito existente, e que faz parte do nosso pensamento, deve-se a uma imensa cadeia de analogias que foram e são elaboradas ao longo do tempo. Este processo de "analogização" resulta no surgimento dos conceitos e continua sofrendo modificações durante toda nossa vida. Durante o desenvolvimento do texto, apresentaremos argumentos assim como

\footnotetext{
${ }^{8} \mathrm{O}$ exemplo dado em seu trabalho (Analogie et métaphore argumentatives) diz respeito à analogia entre a irrigação de um jardim via canos e a circulação sanguínea, proposta por Aristóteles (Des parties des Animaux, III, v, 668 a 13 et 34). O obstaculo epistemológico no exemplo em questão se dá na compreensão da circulação sanguínea uma vez que a água se perde no solo durante a irrigação.
} 
exemplos a fim de elucidar nossa perspectiva, no que tange ao papel das analogias na formação dos diversos conceitos presentes na estrutura cognitiva do individuo.

Primeiramente apresentamos o conceito de analogia e o processo de categorização. Diferentemente de algumas perspectivas que julgamos reducionistas, não entendemos as categorias como resultado de "etiquetagem" que fixa as palavras a conceitos. Antes, porém, entendemos que o processo de categorização e o "uso" de analogias constituem um par dialético. Este depende não somente da nossa língua, mas também da nossa cultura e da época em que vivemos. Destacamos este ponto, pois há visões referentes ao mecanismo psicológico de categorização que entendem que tal processo consiste em organizar os conceitos em categorias pré-existentes e não ambíguas. Seria como organizar talheres dentro de uma gaveta de uma cozinha em que as colheres estariam num compartimento marcado por uma etiqueta "colheres", as facas em outro compartimento etiquetado "facas" etc. Ao pensarmos assim, cada entidade do mundo, concreta ou abstrata, teria seu "compartimento mental" ou sua "categoria mental"; esta seria referente ao agrupamento de todas as entidades do mesmo tipo: os ursos seriam todos reconhecidos como pertencentes a categoria "ursos". Comportamentos poderiam ser organizados da mesma forma e, assim, poderíamos ter categorias como "que se movimenta" ou "que não se movimenta". A compreensão do mecanismo psicológico de separar em "caixas-categorias" parece apontar para um reconhecimento instantâneo e inequívoco de tudo que nos rodeia. Na verdade, tal processo atribui às categorias mentais uma função de reconhecimento das entidades do mundo cuja identidade é objetiva e independente do observador.

De acordo com a perspectiva adotada neste texto, a visão de categorização supracitada é reducionista. Ao contrário do que foi descrito, entendemos como categoria uma estrutura mental que evolui ao longo do tempo, às vezes lentamente, às vezes rapidamente, e que mantém certa estrutura organizada que permite o seu acesso. Por outro lado, o processo de categorização consiste em uma associação provisória de um conceito, uma entidade ou uma situação a uma categoria já existente na estrutura cognitiva do sujeito. O teor provisório, a falta de fronteiras claras e definidas, assim como a natureza precária e graduada do processo de categorização parece, em princípio, reforçar uma ideia de falibilidade do processo. Por isso, na tentativa de "fugir" de tais características que atribuiriam a estas certo 
grau de incredibilidade, muitas vezes, ao criar as categorias, as julgamos como sem ambiguidades, quem sabe absolutas, na medida em que a maior parte das categorias que usamos parecem ter fronteiras muito bem definidas. Afinal, em situações do cotidiano, não confundiríamos categorias mentais como "carro" e "mamãe". Mesmo crianças que estão ainda se apropriando da linguagem falada reconheceriam claramente as fronteiras das duas categorias supracitadas.

São impressões como as descritas anteriormente, somadas ao fato de não estarmos habituados ao exercício do questionamento do uso das palavras em seu contexto cotidiano, que reforçam a ideia rígida e superficial das categorias. $O$ sentimento ilusório de precisão na "etiquetagem" na classificação dos conceitos pode nos conduzir a ideias confusas no processo cognitivo de categorização. A perspectiva adotada neste trabalho vai de encontro a certas concepções tradicionais, pois ressalta que o processo de categorização é gradual, não definitiva/classificatória. A natureza das categorias mentais é sutil e por vezes difusa. Por esse motivo, entender o processo de categorização sob esta perspectiva requer uma análise aprofundada a fim de perceber que, mesmo mediante tais características, é possível pensar em categorias. Desta forma, ao longo deste capítulo, buscaremos aprofundar as posições aqui expostas, no sentido de elucidar o papel da categorização e da analogia na compreensão de novos conceitos.

\subsubsection{Algumas concepções de analogias}

Ao mencionarmos a palavra analogia, é bem provável que algumas situações sejam evocadas. Não é incomum que esta palavra seja usada em diversos discursos a fim de aproximar o público ouvinte ou leitor de uma situação, enunciada e julgada pelo interlocutor, possivelmente afastada deles. Tendo em conta a pluralidade de contextos e as diversas funções legítimas do uso da palavra analogia, pretendemos explicitar duas delas e, em seguida, apontar em que perspectiva trataremos as analogias no presente capítulo.

No trabalho de Curtis e Reigeluth (1984) certos padrões de testes são baseados numa concepção particular de analogia, a qual denominamos "analogia de proporcionalidade". De fato, estas são definidas como analogias entre duas 
relações, compostas de quatro termos, cada uma delas unindo dois elementos. Tal forma de analogia possui um enunciado preciso, lógico, do tipo:

"mosca voa e baleia nada" ou "mosca : voa : : baleia : nada"

Esse tipo de associação é muito presente nos testes de inteligência, nos quais se busca inferir um elemento desconhecido como nos seguintes exemplos: "esfera:cubo :: circulo:X"; "café:preto :: leite:Y"; "céu:pássaros :: oceano:W"; "Brasil:futebol :: EUA:Z". Tais analogias são chamadas "proporcionais" no sentido de atribuir a estas uma ideia de duas proporções $(a / b=p / m)$, sobre as quais se inferem relações de semelhanças entre entidades ou ideias quaisquer. Pensar que uma analogia é definida pelo esquema formal acima descrito, ou seja, formada por quatro elementos, é também remeter a estruturas de silogismos lógicos de Aristóteles. Pode-se considerar que o filósofo grego foi o primeiro a estudar as analogias proporcionais e a afirmar que estas pertencem ao mesmo conjunto lógico da indução e da dedução.

Segundo Hofstadter e Sander (2013), o fato de ainda hoje pessoas entenderem a analogia como descrevemos aqui tem sua legitimidade histórica incontestável. No entanto, uma concepção assim restritiva atribui ao termo "analogia" um conceito de atividade mental abstrata, particular e limitada, fazendo com que esta não se manifeste, salvo em situações raras. Todavia, o "status" que reivindicamos à analogia não limita sua presença em relações de proporcionalidades como as que apresentamos anteriormente. Destacamos que, ainda que a maioria das relações aqui apresentadas admita uma "inequívoca" resposta, os dois últimos exemplos poderiam sem grandes problemas colocar em xeque a ideia de solução única. Por exemplo, na analogia de proporcionalidade "céu:pássaros :: oceano:W", para a qual em princípio se admite como reposta peixes, não seria considerado absurdo se atribuíssemos a $\mathrm{W}$ respostas como moluscos e corais ${ }^{10}$. Assim como no exemplo "Brasil : futebol :: EUA: Z" que admite como resposta o futebol americano, repostas como: baseball, basquete, e até mesmo jazz ou blues, seriam perfeitamente coerentes com a analogia de proporcionalidade em questão.

\footnotetext{
${ }^{9}$ Lembramos que o status aqui reividicado diz respeito ao pensamento do ser humano. O par dialético categorização-analogia é considerado seu fundamento.

${ }^{10}$ Mesmo que haja qualquer falta de rigor ao nivel da taxonomia, tais respostas podem ser justificadas de acordo com a estrutura de proporcionalidade adotada.
} 
Não se trata aqui de tentar excluir o papel desempenhado por tais estruturas. No entanto, chamamos a atenção, ainda de acordo com a perspectiva aqui adotada, para o fato de que, por mais que estas nos pareçam precisas e organizadas, não dão conta de explicar o complexo processo do pensamento humano. De fato, o que defendemos nesse capítulo é justamente o papel central das analogias (no senso que ainda precisaremos) na formação dos conceitos. Afinal, apontamos o par dialético categorização-analogia como o centro e a origem do pensamento. Se a categorização pode ser entendida como o "coração" do pensamento, a analogia é então o seu "motor".

Uma segunda forma sob a qual a analogia se apresenta diz respeito ao uso consciente de analogias que se propõem a aproximar estruturas ou conceitos de domínios aparentemente sem relação direta. Esta forma complexa e sofisticada de elaboração de analogias está presente em diversas e inspiradoras descobertas. Não são poucos os episódios nos campos da ciência, da matemática e das artes nos quais percebemos uma relação outrora não identificada e que, por consequência, tenha conduzido à criação. Podemos, por exemplo, perceber no relato do ilustre matemático Henri Poincaré, “(...) No momento que colocava o pé no degrau, sem que, segundo me pareceu, tivesse relação com o que estava a pensar, veio-me a ideia de que as transformações que tinha utilizado para definir as funções fuchsianas eram idênticas às da Geometria não euclidiana. (...) Um dia, enquanto passeava por um alcantilado, veio-me a ideia, sempre com as mesmas características de brevidade, instantaneidade e certeza imediata, de que as transformações de formas quadráticas ternárias indeterminadas eram idênticas às da Geometria não euclidiana." ${ }^{11}$ Ao vincularmos o uso de analogias a momentos de criação como o descrito acima, podemos reforçar o estereótipo ao qual associamos analogias a ações cognitivas reservadas a momentos "raros" e exclusivos a mentes privilegiadas, com grande potencial criativo, como grandes cientistas ou artistas.

No entanto, se não considerarmos que este tipo de raciocínio sofisticado esteja ligado exclusivamente a momentos de descoberta e criação, encontraremos diversas atividades do cotidiano que são baseadas no princípio de que,

\footnotetext{
${ }^{11}$ Conferência apresentada na Sociedade de Psicologia de Paris, no início do Século XX, publicada originalmente no Bulletin de I'Institut Géneral de Psycologie, № 3, 1908, Paris. Republicada em P. Abrantes, L. C. Leal, \& J. P. Ponte (Eds.) (1996), Investigar para aprender matemática (pp. 7-14). Lisboa: Projecto MPT e APM. (Tradução de Henrique M. Guimarães)
} 
intencionalmente, aproximamos dois domínios diferentes e sem relação imediata. Dentre essas, menos ordinárias, apontamos as atividades de ensino. Como apresentamos no capítulo anterior, centrados apenas no domínio das ciências, encontramos diversos exemplos nos quais pensar por analogia tem o seu papel justificado. Reconhecemos o papel das analogias nas duas formas supracitadas, entretanto, buscamos aqui esclarecer a perspectiva na qual as analogias não são casos particulares e raros. Ao contrário, estas são parte constituinte da estrutura do pensamento humano.

Analogias entendidas no formato de proporcionalidade apresentam limitações e restrições de uso. Algumas dessas questões já foram apresentadas e nos limitaremos a esta breve abordagem, uma vez que essa estrutura não coincide com a perspectiva sustentada na presente tese. Em relação à segunda estrutura de analogia apresentada, na qual aproximamos um domínio conhecido de um novo, a fim de dar sentido a este, a julgamos pertinente porque, sobretudo, é esta a estrutura apresentada pelos trabalhos na área de ensino de ciências dedicados ao uso de analogias como instrumento didático. Por isso, ainda neste capítulo, voltaremos a discutir este tipo de estrutura, dessa vez baseados não em trabalhos na referida área de pesquisa, mas antes nas reflexões propostas pela perspectiva adotada da psicologia cognitiva. Ainda que esta estrutura represente o foco de nossa tese, este capítulo é dedicado a pensar o uso de analogias num quadro ainda mais geral. O status, em princípio "audacioso", aqui reivindicado coloca as analogias no centro do processo cognitivo humano. Por isso, mesmo reconhecendo o complexo processo do uso de analogias, dado pela segunda perspectiva, limitar o seu papel a esses tipo de atividades é minimizar sua importância ou, no mínimo, perder de vista a sua potencialidade. Na verdade, o que esperamos é, a partir da perspectiva segundo a qual as analogias representam um papel fundamental no processo cognitivo, em si mesmo, construir um quadro teórico que dialogue com as perspectivas da epistemologia da ciência que apresentaremos no capítulo seguinte. $\mathrm{Na}$ verdade, buscamos uma síntese das três perspectivas presentes em nossa tese (como apresentamos anteriormente: analogia como elemento do par dialético categorização-analogia, analogia como elemento presente na elaboração de uma teoria assim como sua comunicação e o uso de analogias em atividades didáticas de ciências). Nesse sentido, a próxima seção passa a esclarecer a primeira perspectiva. 


\subsubsection{Analogia e Categorização}

Explicitamos anteriormente que o conceito de categoria aqui adotado difere das concepções nas quais "as coisas do mundo" são classificadas de forma inequívoca. Ao contrário, entendemos que as categorias possuem um caráter provisório, e portanto histórico, que as fronteiras entre categorias não são bem definidas e que, sobretudo, constroem-se juntamente com o desenvolvimento dos conceitos na estrutura cognitiva do indivíduo. No entanto, a "falta de precisão" na determinação dos limites entre categorias não inviabiliza a distinção dos conceitos em nossas atividades, ou seja, à medida que os colocamos em prática os significados contextuais ganham sentido na ação realizada. Esta evolução se dá de forma incessante, conforme somos colocados face a novas situações de uso. $\mathrm{Na}$ verdade, as situações de uso de um conceito nunca são contextualmente coincidentes, por isso toda vez que um conceito é "utilizado", o par dialético categorização-analogia é evocado, e este ganha um novo status na estrutura mental do sujeito cognoscente.

Para que este modelo dê conta de explicar o complexo processo de classificação dos conceitos na estrutura cognitiva do sujeito, no lugar de discutir o conceito de categoria mental, vamos apresentar o processo de categorização na tentativa de superar concepções indesejadas e reducionistas do referido conceito, apontadas em algumas visões. A perspectiva deste trabalho aponta para um processo dinâmico, em detrimento do processo estático de categorias. Consideramos que o processo de categorização não pode ser entendido separadamente do uso de analogias, por isso insistimos no papel do par dialético, ao invés de pensarmos nos dois processos de forma independente. Aqui lançaremos mão de um conjunto de exemplos a fim de mostrar como as palavras, as expressões e frases ganham significados em nossa estrutura cognitiva.

\subsubsection{Os Zeugmas}

Antes de abordarmos a questão das "etiquetas lexicais" na categorização das palavras e estendermos aos significados das expressões, julgamos pertinentes 
apresentar o fenômeno linguístico denominado "zeugma"12, que nos permite explicitar a riqueza escondida "por trás" das palavras e, partindo delas, dos conceitos.

Hofstadter e Sander (2013) apresentam em seu livro uma série de exemplos de zeugmas aos quais recorremos a fim de tornar cada vez mais clara a perspectiva aqui adotada. Segundo os autores, os zeugmas constituem uma figura de linguagem clássica na qual, na maioria das vezes tendo uma tonalidade humorística, vários sentidos de uma mesma palavra são evocados, ainda que esta apareça uma única vez. Destacamos a seguir alguns exemplos de zeugmas:

Ele era e falava alemão

\section{Ela me devolveu o troco e a vontade de sorrir}

No primeiro exemplo, a palavra "alemão" desempenha duplo valor semântico, ora ela desempenha o papel de adjetivo designando a nacionalidade do sujeito, ora desempenha o papel de substantivo significando o idioma falado por ele. Já no exemplo seguinte, a palavra "troco" e a expressão "vontade de viver" são utilizadas na frase regidas pelo mesmo verbo "devolver". Este verbo pode evocar o sentido de restituição de algo, o que seria bem aplicado à palavra "troco", mas não à expressão "vontade de viver". Afinal, para devolvermos o troco a alguém precisamos antes ter recebido o pagamento, no entanto, a vontade de sorrir ou de viver não está associada ao recebimento prévio de algo.

A fim de tornar um pouco mais ampla a discussão semântica revelada pelos zeugmas, tomemos apenas um exemplo de frases que perdem o seu sentido zeugmático se apresentadas em outro idioma. Se escrevêssemos em francês a frase "Geoffroy joue au football et du piano" a um francófono ou mesmo em inglês "Geoffroy plays soccer and piano" a um estadunidense, isso não caracterizaria nenhum tipo de estranheza. No entanto, se tentarmos reunir as duas ações numa mesma categoria em português, como o fazem em inglês e em francês, a frase perde seu senso e torna-se absurda. Afinal, ninguém que tenha o português como

\footnotetext{
${ }^{12}$ Figura pela qual uma palavra, já expressa numa proposição, se subentende noutra ou noutras que com a primeira têm analogia ou relação. "zeugma", in Dicionário Priberam da Língua Portuguesa [em linha], 2008-2013, http://www.priberam.pt/dlpo/zeugma [consultado em 11-12-2014].
} 
idioma materno achará razoável a construção da frase "Geoffroy joga futebol e piano". No nosso idioma, a prática de esportes e a prática musical com algum instrumento pertencem a conjuntos de ações distintas, por isso jogamos futebol e tocamos piano. Poderíamos, no entanto, encontrar atividades que em nosso idioma pertencem à mesma família, e por isso usamos o mesmo verbo, enquanto em outro idioma a classificação das mesmas ações seja feita de forma distinta, usando assim dois verbos distintos. Vejamos o exemplo da frase "O menino e o cão comeram pão". Nesta frase comer para um menino ou para um cão é a mesma atividade, entretanto, a sentença não poderia ser formulada da mesma maneira em alemão, porque os animais " fressen" enquanto os seres humanos "essen"13.

Poderíamos complexificar ainda mais, se imaginássemos um idioma que classificara historicamente suas atividades de forma distinta daquelas a que estaríamos habituados. Por exemplo, um idioma que fora desenvolvido em contextos nos quais algumas atividades infantis fossem classificadas de forma distinta das "mesmas" atividades realizadas por adultos. No hipotético idioma, uma criança, quando triste, "infchora", enquanto um adulto expressa sua emoção "senchorando". Tais exemplos podem, em princípio, parecer absurdos ou sem sentido. No entanto, através de exemplos como estes, chamamos a atenção para o processo de classificação das palavras e de como o par dialético categorização-analogia ganha sentido. Fundamentalmente, buscamos mostrar que a formação de conceitos e os sentidos das palavras são construídos nas atividades humanas, sem as quais uma palavra seria apenas um conjunto de grafias e/ou de fonemas, tendo uma possível interação com nosso sistema de percepção de estímulos, dada sua natureza física, mas sem causar nenhuma mudança estrutural em nosso sistema cognitivo. Em outras palavras, não passariam de ruídos.

\subsubsection{Relação de significação nas palavras}

Neste tópico nos dedicamos à compreensão de categorias descritas por uma só palavra. Buscamos, então, mostrar como as fronteiras das categorias se

\footnotetext{
${ }^{13}$ Não propomos a construção da frase equivalente em alemão, pois esta apresenta uma forma mais complexa e foge ao nosso objetivo. O referido exemplo busca apenas reforçar a complexidade da dinâmica de categorização evocada nos exemplos de zeugmas.
} 
estendem, por meio de incessantes analogias, num processo que se aproxima a uma generalização de conceitos. Ao mesmo tempo, num processo inverso, as categorias ganham um refinamento, permitindo a estas certo grau de objetivação essencial na ação do sujeito no mundo. Um dos exemplos usados por Hofstadter e Sander (2013) e explorados no presente tópico é o da categoria mãe. Inicialmente surge na vida da criança como categoria conceitual exclusiva da sua mãe (que é aplicada, nesse caso, a um individuo específico) e tem sua evolução conceitual passando, por exemplo, pelo conceito de mãe genitora, tendo aqui um status de categoria geral abstrata, e atingindo conceitos de ordem metafórica como o de mãe natureza ou pátria mãe. Buscamos também mostrar como conceitos não tão concretos, como os conceitos de <bom dia>, <amanhã $>$, <muito>, <mas> etc, são conceitos abstratos que também participam do processo de categorização-analogia na construção dinâmica de seus significados.

Propomos inicialmente uma reflexão a respeito de como as palavras surgem e qual é sua relação com o pensamento. Como destacam Hofstadter e Sander (2013), somos constantemente colocados face a novas situações. Na verdade, mais do que situações particularmente novas, nosso pensamento é "invadido" por inúmeras situações que são superpostas e "entrelaçadas".

Estamos envolvidos em atividades diversas e múltiplas. Alguém que utilize o metrô para se deslocar de casa para o trabalho, depara dentro do transporte público com alguns rostos e semblantes que Ihes chamam a atenção, enquanto outros menos, alguém que fala ao telefone e gesticula, acompanhamos os nomes das estações, lemos as publicidades espalhadas no interior do metrô, um senhor que toca um acordeom e nos remete a um lugar distante, uma notícia de primeira capa estampada no jornal do senhor que está sentado ao nosso lado rouba nossa atenção, ao mesmo tempo estamos mergulhados em nossos pensamentos vinculados a questões que não pertencem ao contexto do interior do metrô e seu entorno. As situações aqui descritas são apresentadas a fim de percebermos que, longe de nos depararmos com situações bem definidas, nosso pensamento é tomado por esse "turbilhão" de impressões.

A leitura desse mundo complexo e tomado pela multiplicidade de atividades requer, de certa forma, num dado evento, rápida interpretação. Mas como interpretar 
esse turbilhão de ações? A resposta por nós apontada passa exatamente pelo par dialético analogia-e-categorização ${ }^{14}$. É na ação interpretativa que são evocadas involuntariamente as categorias já familiares ao sujeito, que, uma vez "despertadas", se apresentam como elementos essenciais no processo de objetivação e categorização dos conceitos envolvidos. Destacamos, então, que a referida categorização é realizada por meio de analogias.

Antes de retomar o exemplo do conceito de "Mãe"15, é importante destacar a diferença entre uma palavra e um conceito. Apesar de sua forte relação e, por vezes, ambiguidade:

Esta distinção é importante, pois uma palavra é uma etiqueta da língua composta de uma sequência de sons, uma combinação de letras ou de um elemento de linguagem interiorizada, enquanto que um conceito é uma representação cerebral abstrata, à qual vinculase às vezes apenas uma palavra, às vezes várias e outras vezes nenhuma. As palavras e os conceitos são coisas diferentes. (HOFSTADTER e SANDER, 2013, p.46, tradução nossa)

Na maioria das vezes uma das primeiras categorias mentais formadas na vida de um sujeito é o conceito de Mãe. Por isso o tomamos como ponto de partida, a fim de destacar o papel do par dialético analogia-categorização na formação de conceitos.

Tomamos como exemplo uma situação hipotética apresentada por Hofstadter e Sander (2013), de um menino de um ano e meio de idade ao qual chamaremos de Vicente. Ao passear com sua mãe num parque público, Vicente depara com outra criança que é conduzida e cuidada, assim como ele, por um adulto. Em seguida, o pequeno Vicente percebe que seu "coleguinha" de idade chama a este adulto utilizando uma palavra muito comum a ele, a saber, << Mamãe>>. Imediatamente, uma combinação de estranheza e de descoberta tomam conta de seu pensamento. Parece que <<Mamãe>> não é uma palavra de uso exclusivo seu, ou seja, o conceito Mamãe, já existente como categoria mental do Vicente é evocado a fim de

\footnotetext{
${ }^{14}$ Reforçamos a ideia de que a analogia e o processo de categorização não devem ser analisados isoladamente, representando-os agora pelo par dialético <<analogia-e-categorização>>, justificando assim a inclusão do <<e >> na relação entre os dois termos.

${ }^{15}$ Adotamos aqui a mesma notação do livro «L'Analogie - Cœur de la Pensée », a saber, a fim de explicitarmos se o que escrevemos diz respeito a uma palavra ou a um conceito, quando nós falarmos de uma palavra, a representaremos entre aspas ( "mãe »). Já quando falarmos de um conceito ao qual um substantivo é associado ao léxico, o representaremos em itálico (mãe).
} 
ser confrontado à presente situação. Está "nascendo" aí uma nova categoria de Mamãe, causada não apenas pela utilização da palavra $<<$ Mamãe $>>$, mas pela relação de semelhança com o conceito Mamãe outrora formado. Na verdade, características comuns como: um adulto; que cuida; que dispensa carinho, que alimenta, associadas à utilização do termo << Mamãe>> permitem ao Vicente expandir aquilo que até então ele reconhecia como significado de Mamãe. Tal conceito passa de um individuo para uma categoria de um conjunto de indivíduos. $\mathrm{Na}$ tentativa de preservar a individualidade de sua Mamãe, talvez ele faça uma distinção entre Mamãe (correspondente a sua mãe) e mamãe (destinadas as demais). Sendo assim, a evolução do conceito Mamãe "trafega" entre o singular e o plural, entre o maiúsculo e o minúsculo.

É a partir desse momento que as representações mentais de duas situações começam a se misturar. Um conceito de Mamãe menos específico e mais geral começa a ganhar espaço na estrutura cognitiva da criança. Como apontamos anteriormente, um duplo movimento aparece, a saber, ao mesmo tempo que ocorre a "generalização" do conceito, no sentido de sua ampliação para outros casos, este parece, ainda que "difuso", criar um novo. O conceito primeiro de Mamãe e o outro, um pouco mais sofisticado, de mamãe apresentam característica similares. Cada um deles ao ser confrontado com novas situações segue os seus próprios percursos de extensão. Este processo contínuo está presente durante toda a vida do sujeito e serve de guia de nosso pensamento em circunstâncias que variam das mais rudimentares e cotidianas às mais sofisticadas. É então nessa relação com categorias mentais familiares confrontadas a novas situações, gerando a expansão dos conceitos, que identificamos a ação das analogias-e-categorizações.

A fim de reforçar nossa perspectiva, imaginemos que Vicente infelizmente não tenha jamais conhecido o seu pai. Um dia Vicente, ao brincar no parque, percebe uma menininha que está acompanhada de um adulto que cuida dela de maneira muito semelhante a de sua mãe. Vicente, então, por analogia, infere que o adulto ao qual nos referimos pertence à categoria mental de mamãe. Ele criara uma ligação entre o que observara e o seu novo conceito de mamãe. No entanto, é possível que se trate do pai da menina, da avó, de um tio, ou de uma irmã ou um irmão mais velho. Nessa fase, entretanto, a criança experimenta, por meio do uso, os novos conceitos formados, e estes adquirem significados cada vez mais amplos. 
A partir de sua experiência com novas situações, Vicente será capaz de, além de estender suas categorias mentais, identificar novas características de refinamento de seus conceitos. No caso de Vicente em particular, em breve ele vai perceber que o conceito mamãe não é aplicável ao gênero masculino, ao qual designamos a palavra <<papai>> em certas situações. Percebemos nesse movimento também o surgimento de uma nova categoria, que a partir desse momento segue um percurso semelhante aos demais conceitos.

Destacamos aqui um ponto muito importante no processo de formação dos conceitos, fundamentalmente quando trabalhamos na perspectiva da formação de conceitos científicos, a saber, na evolução dos conceitos na história do sujeito, os conceitos primordiais sempre deixam "traços".

\begin{abstract}
À medida que ele utiliza a palavra $<<$ mamãe $>>$, sua primeira imagem - aquela da própria mãe - se perde, como uma raiz que se enterra cada vez mais profundamente com o tempo. A esta primeira imagem, ele mistura, a partir dai, características de outras pessoas as quais agrega a esta categoria mental, e as características marcantes e únicas de sua Mãe tornam-se cada vez mais difíceis de identificar. No entanto mesmo quando for adulto, no cerne do conceito mamãe subsistirão ainda vestígios do conceito primordial de Mamãe. (HOFSTADTER e SANDER, 2013, p.48, tradução nossa)
\end{abstract}

Para o filósofo da ciência Gaston Bachelard (1934), conceitos ordinários precisam ser superados e dar lugar aos conceitos científicos. Segundo o filósofo francês, os "traços" de conceitos ordinários podem levar ao que ele denomina de obstáculos epistemológicos. No entanto, de acordo com a perspectiva adotada na presente tese, conceitos científicos, como, por exemplo, o peso, não vão substituir e apagar os "traços" do conceito "primitivo" de peso, antes, porém, este amplia o seu campo de ação em atividades contextuais.

Mesmo considerando, em princípio, o conceito de mamãe como sendo preciso, seríamos capazes, no entanto, de perceber nuanças que atribuem certo grau de dificuldade à questão do tipo: "o sujeito X é uma mãe ou não?". Por exemplo, em uma brincadeira, uma criança atribui a duas de suas bonecas o papel social de mãe e filha, dizendo que a primeira é a mamãe da segunda. Se $X$ representado na questão acima for substituído pela segunda boneca, podemos responder objetivamente de forma positiva à referida questão? Na verdade diversas situações podem ser propostas, a fim de complexificar a presente questão, que 
remete ao conceito de categoria como o entendemos. Ao invés de encará-lo como uma estrutura rígida e objetiva, o exemplo aqui apresentado reforça a ideia do significado que surge na atividade contextual.

É provável que Vicente depare com situações nas quais o conceito de mamãe se encontra com o conceito simples de mãe, como, por exemplo, ao perceber que sua Mamãe também possui alguém com a qual ela tem uma relação que mostra certa semelhança com a relação entre ele e sua Mamãe, mas a quem ela chama simplesmente de mãe. Passados alguns anos, o pequeno Vicente é colocado frente a atividades nas quais o conceito de mãe se amplia e é aplicado em diferentes áreas, como: "Mãe Terra"; "Mãe natureza"; "placa mãe"; "a religião judaica é a mãe da religião cristã". Todos esses exemplos podem ser constituídos como exemplos de "mães legítimas".

Como adultos temos nosso repertório rico e diverso dos conceitos associados à palavra <<mãe >>. Portanto, as categorias mentais vinculadas às palavras não são fixas e tampouco possuem fronteiras objetivas e bem definidas. Mesmo assim, essa "imprecisão" não nos impede de usar os conceitos de forma adequada nas atividades, à medida que estes são evocados. Sobretudo, os conceitos estão em constante reformulação, seguindo a dinâmica de refinamento e generalização.

A fim de explicitar o processo de analogia-e-categorização por meio do uso dos conceitos, lançamos mão de um repertório de enunciados de crianças, reunidos pela psicolinguista Karine Duvignau junto aos pais que observaram seus filhos em casa:

\section{Camille, de 2 anos de idade, diz: "Eu despi a banana"}

Camille fala da banana como se ela fosse uma pessoa ou uma boneca; ela vê a casca da banana como a roupa que ela veste; a banana então "fica nua".

Joane, de 2 anos de idade, diz à sua mãe: "Vai, Mamãe, liga os olhos!" eletrônico.

Dessa vez a criança fala de um ser humano como se ele fosse um aparelho eletro-

Jules, de 3 anos de idade, diz: "Ela desligou, a chuva!"

Para Jules, a chuva é como a televisão ou uma lâmpada, e alguém pode ligá-la ou desligá-la com a ajuda de um interruptor. da Índia?"

Tom, de 8 anos de idade, pergunta: "Papai, quanto tempo dura um porquinho 
É sim, Tom fala de seu porquinho da Índia como de um objeto vulgar de consumação, no entanto ao ver com que afeição ele o acaricia, compreendemos que sua categoria intitulada "coisas com duração limitada" é muito mais ampla que a dos adultos.

Ainda Tom, com a mesma idade, percebe que seu tio distraído em sua conversa deixa seu cigarro se consumir no cinzeiro. Ele Ihe diz: "Titio, teu cigarro está derretendo"

Mesmo que ele saiba bem que cigarros não são destinados às crianças, Tom parece pensar que eles possam derreter como coisas que lhe são familiares, como sorvetes ou 0 chocolate. (HOFSTADTER e SANDER, 2013, p.53-54, tradução nossa)

Os relatos acima correspondem a trechos de falas de crianças que experimentam o uso da língua em situações que envolvem certos conceitos sobre os quais elas estão ainda em fase de compreensão. Tais falas não correspondem a momentos raros na vida das crianças, mas, ao contrário, representam momentos constantes de experimentação do mundo. Apesar de sua frequência, estes extratos de discurso são riquíssimos e trazem contribuições à compreensão do funcionamento do complexo mecanismo de formação de conceitos. Contudo, na maioria das vezes, ao ouvirmos frases semelhantes provenientes de crianças na faixa etária correspondente aos relatos acima, somos levados a rir e às vezes corrigir o mau emprego do termo na respectiva frase. Obviamente que nosso olhar é particular, e em certa medida privilegiado, o que nos permite perceber relações intrínsecas ao discurso de experimentação.

Vale destacar, na frase dita por Camille (“Eu despi a banana”), que a categoria mental despir é bem mais ampla que no caso de um adulto, podendo esta ser aplicada a frutas, a um embrulho ou a qualquer outra ação em que criança perceba um grau de semelhança. Isso nos leva a pensar que a criança (nesse caso particular a Camille) recorre a situações familiares na tentativa de agir ou interpretar uma nova situação. O que seria esse processo se não o uso da analogia na categorização dos conceitos ali evocados, em outras palavras, é a emergência do par dialético analogia-e-categorização. O processo torna-se ainda mais evidente ao destacarmos a análise da frase: "Camille fala da banana como se ela fosse uma pessoa ou uma boneca; ela vê a casca da banana como a roupa que ela veste; a banana então "fica nua"." Fica clara a analogia entre pessoa/boneca e banana, e entre casca da banana e roupa. 
Fica fácil estender esta análise para os demais relatos. Da mesma forma que o conceito de despir segundo Camille, os conceitos de ligar, desligar, duração e derreter para as outras crianças citadas nos relatos são menos específicos que se aplicados a adultos. O refinamento dos conceitos ocorre à medida que as crianças deparam com novas situações e percebem o uso de novos termos em situações aparentemente sem distinção das demais que Ihes são familiares. Por exemplo, quando Tom adverte seu tio de que seu cigarro está derretendo, ele ainda classifica atividade de consumo de um cigarro pelo fogo como semelhante a atividades nas quais ocorre também o consumo de outros "objetos", como é o caso do sorvete e também do chocolate. A analogia elaborada por Tom não é absurda, pois todos os casos, cigarro aceso, sorvete fora da refrigeração e chocolate exposto a temperaturas "elevadas", apresentam seu volume diminuído com o passar do tempo, mesmo que achemos inapropriado o uso do verbo derreter ao consumo de um cigarro aceso em repouso no cinzeiro. É, portanto, à medida que o menino depara com novas atividades, e por meio do incessante processo analogia-e-categorização, que Tom mantém em constante evolução suas categorias mentais.

Desta forma, apontamos que as fronteiras entre um enunciado incorreto e outro correto são menos rígidas do que podemos imaginar. As crianças citadas no presente relato fazem aproximações semânticas que para os adultos não são permitidas. O que destacamos por meio dos exemplos aqui utilizados é que os conceitos que estão por trás das palavras seguem um percurso de evolução/desenvolvimento da mesma forma que o conceito de mãe evolui para Vicente.

Seria possível destacar um conjunto quase infinito de palavras e conceitos que evoluem ao longo do desenvolvimento do sujeito. No entanto, selecionamos os exemplos supracitados a fim de mostrar de que forma o processo analogia-ecategorização se coloca como elemento fundamental na formação dos primeiros conceitos na vida de um indivíduo. No entanto, o processo analogia-e-categorização não se limita à formação de conceitos ordinários e atua além das palavras, mas também em expressões e enunciados mais complexos.

O ponto principal de nossa análise é defender que cada conceito envolve um processo constante de elaboração, no qual identificamos contextos de uso por 
aproximação. Sempre que buscamos identificação entre duas situações concretas diferentes, estamos compondo uma analogia e, por meio dela, criando uma categorização que dá destaque a elementos semelhantes presentes em ambos os casos, permitindo uma significação mais geral aos mesmos. Contudo, esta aparente generalização não consiste na construção de um conceito abstrato que tem como função substituir um conjunto de referentes no mundo que podem ser considerados de mesma natureza. Ao contrário, a discussão anterior busca mostrar que a formação conceitual se baseia mais em criação de analogias que, após determinado tempo, ganham estabilidade em um determinado tempo e cultura.

\subsection{Dialogando com teorias sócio-históricas da psicologia}

Recorremos à figura de linguagem "zeugma" a fim de causar propositalmente no leitor um desconforto quanto ao significado das palavras. O exercício proposto na análise dos exemplos de zeugmas, em certo sentido, é similar ao processo denominado "unzip", o qual tem por objetivo principal trazer ao nível consciente as operações automatizadas, e assim tornar evidentes suas relações e significados. No olhar da teoria da atividade, o jogo com as palavras suscitado pelos zeugmas permite-nos explicitar os significados em potencial contido nas palavras.

Os processos "automatizados" (operações) estão presentes em "atividades" (ações) como dirigir um carro, jogar uma partida de voleibol ou executar um cálculo aritmético. As operações, em certo sentido, correspondem à autonomia nos processos que foram incorporados por nosso sistema cognitivo e não necessitam mais de sua realização consciente, lembrando que cada ação pode ser compreendida como um conjunto de operações, e que uma mesma ação pode ser realizada por uma combinação diferente de operações, assim como ações diferentes podem ser realizadas pelas mesmas operações. Nesse sentido, compreendemos que as operações que compõem as ações de dirigir realizadas por um condutor experiente são cumpridas automaticamente, ou seja, sem a constante mediação da consciência. No entanto, se o referido condutor desempenha a função social de um instrutor de autoescola, ele deve organizar as atividades de seu aprendiz, a fim de que este possa se apropriar das operações que compõem a atividade de dirigir. Isso 
significa que, primeiramente, o instrutor necessita trazer ao nível da consciência todas as operações que já foram por ele internalizadas e, portanto, que são realizadas automaticamente. O processo que denominamos "unzip" é necessário a qualquer atividade de ensino, afinal, à medida que propomos tornar inteligíveis os processos que culminam na realização de uma atividade, as operações precisam se realizar no nível de ações conscientes.

Um professor de álgebra que inicia seu curso numa classe de $8^{\circ}$ ano do ensino fundamental, desejando que seus alunos sejam capazes de realizar operações matemáticas com expressões algébricas ao final do curso proposto, precisa incluir no seu planejamento passos que para ele, como professor licenciado em matemática, por exemplo, já foram internalizados e, com isso, não necessitam mais da mediação constante da consciência. Isso significa fazer o "unzip" de todas as operações (no sentido compreendido pela Teoria da Atividade de Leontiev) que serão propostas na atividade "efetuar operações com frações algébricas". Esse exercício realizado pelo professor faz com que ele, mesmo tendo já incorporado tais passos, se aproprie cada vez mais de suas ações, outrora sendo usadas como operações.

No caso dos zeugmas, apesar de não ser uma atividade voltada diretamente ao ensino, o jogo com as palavras permite-nos pensar a respeito do significado, ou mesmo dos significados, aos quais as unidades linguísticas correspondem. Este exercício nos conduz também à percepção da multiplicidade de sentidos assumidos pelas palavras. Para Lev S. Vygotsky, há dois componentes distintos no significado da palavra, a saber, o significado propriamente dito e o sentido. O significado referese ao sistema de relações objetivas envolvidas no desenvolvimento da palavra. $O$ significado apresenta certo grau de estabilidade na compreensão, dado nas relações sociais e vinculados à cultura, de forma a permitir seu compartilhamento entre as pessoas envolvidas no processo de comunicação. Já o sentido é associado ao significado da palavra para cada individuo. O sentido será dado nas relações entre o contexto de uso das palavras e as vivências afetivas do individuo, e, por que não dizer, a memória afetiva do mesmo.

Nossa abordagem está em harmonia com as concepções apontadas pelo psicólogo russo, na medida em que vinculamos o pensamento à linguagem. A fim de 
melhor compreender as questões aqui levantadas, assim como na tentativa de explicitar as relações estabelecidas entre a perspectiva vygotskiana na formação de conceitos e a perspectiva aqui adotada, na qual apontamos a analogia como motor do pensamento, propomos uma reflexão a respeito da abordagem da psicologia do desenvolvimento sócio-histórica de Vygotsky. Antes de tudo, é importante compreendermos de que forma sua psicologia tem seu aporte fundamentado no materialismo-histórico de Karl Marx, e de que forma podemos afirmar que suas ideias concebem uma nova psicologia do desenvolvimento humano. Propomos assim, inicialmente, um breve histórico com a intenção de contextualizar seu pensamento.

Lev Vygotsky (1896-1934) nasceu no final do século XIX, em Orsha, em pleno império russo, na atual Bielorússia. Sua formação inicial se deu por meio de tutores, o que era bastante comum à época para famílias com boas condições sócioeconômicas. Na adolescência Vygotsky se interessou e se encantou com a filosofia, literatura e cultura. Destacou-se como aluno brilhante, mas, como um rapaz de origens judaicas na anti-semita Rússia Czarista, tinha limitações quanto às escolhas no campo de estudo ou na área de atuação futura. Mesmo com todas as dificuldades, conseguiu graduar-se em direito na Universidade de Moscou em 1918, nessa época já União Soviética.

Ao contrário de algumas perspectivas tradicionais que veem 0 desenvolvimento e a aprendizagem como processos duais, Vygotsky tem suas premissas enraizadas na visão de mundo marxista, mais precisamente, no materialismo histórico-dialético. Suas preocupações primordiais podem ser percebidas na questão por ele levantada: "Que novas formas de atividade foram responsáveis por estabelecer o trabalho como o meio fundamental de relacionamento dos seres humanos com a natureza e quais são as consequências psicológicas dessas formas de atividades?' (Vygotsky, 1978, p.19). Não é difícil perceber uma mudança radical na relação desenvolvimento-aprendizagem, se tomamos como parâmetro uma das perspectivas da psicologia tradicional, segundo a qual a aprendizagem está submetida ao desenvolvimento do sujeito, tendo esta uma base biológica determinante. Ele fala de formas de atividades que colocam o trabalho humano como a principal forma de relação entre os homens e entre o homem e a natureza, assim como Marx, e contrariamente à filosofia alemã do século 
XIX, ele não parte de ideias, comportamentos, da imaginação ou do pensamento para chegar ao homem em sua constituição física e em suas relações práticas da vida. Vygotsky faz justamente o caminho inverso, parte do homem e de suas relações em atividades reais. A pergunta feita pelo autor vai mais além. Ela propõe consequências psicológicas das novas formas de atividades, ou seja, o desenvolvimento como resultado da aprendizagem.

Na nova psicologia de Vygotsky vemos também uma nova e revolucionária metodologia. Newman e Holzman (2002) apontam Vygotsky, em certo ponto, como um metodólogo marxista, na medida em que ele partia de um estado real das coisas em contraponto a fundamentos da psicologia que são de natureza dualista e ahistórica. É fundamental destacar que para Marx:

É a partir do seu processo de vida real que se representa o desenvolvimento dos reflexos e das repercussões ideológicas deste processo vital. Mesmo as fantasmagorias correspondem, no cérebro humano, a sublimações necessariamente resultantes do processo da sua vida material que pode ser observado empiricamente e que repousa nas bases materiais. (MARX e ENGELS, 1973, p.47)

É importante perceber que, para Marx, como também para Vygotsky, uma premissa é um estado real de coisas. O filósofo alemão insiste que o ponto de partida das ciências e da história não devem ser as abstrações, extrapolações de uma vida conceitual ou ideal, antes, porém, estas devem ser baseadas nas atividades reais dos homens, ou seja, a vida que é vivida e não na vida idealizada.

Não é a consciência que determina a vida, mas sim a vida que determina a consciência. Na primeira forma de considerar este assunto, parte-se da consciência como sendo o individuo vivo, e na segunda, que corresponde à vida real, parte-se dos próprios indivíduos reais e vivos e considera-se a consciência unicamente como sua consciência.

Esta forma de considerar o assunto não é desprovida de pressupostos. Parte de premissas reais e não as abandona um único instante. Estas premissas são os homens, não isolados nem fixos de uma qualquer forma imaginária, mas apreendidos no seu processo de desenvolvimento real em condições determinadas, desenvolvimento este que é empiricamente. Desde que se represente este processo de atividade vital, a história deixa de ser uma coleção de fatos sem vida, como a apresentem os empiristas, que são eles próprios ainda abstratos, ou a ação imaginária de 
sujeitos imaginários, como a apresentam os idealistas. (MARX e ENGELS, 1973, p.47-48)

A citação acima resume o quadro metodológico de Marx que, baseado nas suas proposições claras, vai nos permitir melhor entender as proposições da nova psicologia de Vygotsky, a partir da qual pretendemos discutir o papel das analogias como ferramentas de mediação entre o sujeito e o novo conceito.

Um dos aspectos mais marcantes e reconhecidos da obra de Vygotsky é o papel fundamental que ele dá às interações no desenvolvimento do sujeitos. Em especial, as interações discursivas são importantes para a apresendizagem das palavras e conceitos, sendo estes compatilhados socioculturalmente. Uma primeira consequência desta afirmação consiste em notar que os significados são compartilhados dentro de situações específicas, que envolvem diferentes modos de ação no mundo, sendo assim fortemente contextuais. Desta forma, o processo de conceitualização emerge a partir de diferentes usos dos termos linguísticos que dão estrutura ao conceito. Sendo assim, a aprendizagem se dá pela aproximação de contextos que guardam alguma semelhaça, cuja dimensão analógica buscamos indicar em nossa análise anterior.

Parece-nos evidente nosso esforço em realizar uma síntese dentro de uma síntese. Se o objetivo da presente tese é encontrar uma síntese entre as três abordagens do tema "o uso de analogias em aulas de física quântica voltada a alunos da educação básica", nosso objetivo nesse momento é buscar uma síntese entre a perspectiva da psicologia cognitiva, a partir da qual centramos as analogias nas atividades de pensamento, fundamentalmente na formação de conceitos, e a perspectiva da psicologia sócio-histórico-dialética de Lev Vygotsky. Para concluirmos a síntese proposta, analisamos com mais detalhes o que apontamos anteriormente como par dialético levantado por Vygotsky, o conceito de \{“desenvolvimento-e-aprendizagem"\}. Para isso lançamos mão de um conceito muito importante na relação instrumento-e-resultado presente nas pesquisas realizadas pelo "metodólogo marxista", assim como nos trabalhos de seus seguidores (autores muitas vezes conhecidos como neo-vygotskianos), o conceito de Zona de Desenvolvimento Proximal, ou simplesmente ZDP. 
A noção de ZDP é por si só rica e revolucionária. Rica em sua potencialidade de compreender as ações humanas e fundamentalmente a relação instrumento-eresultado, dando a esta um "status" de ferramenta metodológica; e revolucionária na medida em que desloca o foco da análise do desenvolvimento da criança. De acordo com Vygotsky (1978), ao analisarmos o que uma criança é capaz de fazer sozinha, sem o auxílio de alguém mais experiente, verificamos o que já está ao nível de desenvolvimento da criança, o que Vygotsky julga completamente inadequado. Para ele, o mais importante é conhecer o que a criança é capaz de fazer com o auxílio de um parceiro "mais capaz".

Newman e Holzman (2002) destacam que, embora as crianças sejam capazes de realizar um maior número de tarefas auxiliadas por um adulto, ou um colega mais experiente, este número não é ilimitado. Na verdade, é a partir dessa afirmação que a ZDP ganha seu potencial de análise, afinal é nesta zona "não tão precisa" que encontramos informações a respeito do "potencial de vir a ser", é na ZDP que o par dialético desenvolvimento-aprendizagem apresenta o seu potencial. Por exemplo, Vygotsky discorda de que, tratando a imitação como um processo fundamentalmente mecânico, uma criança seria capaz de imitar qualquer coisa ou quase tudo. Ele aponta que tanto as crianças quantos os adultos somos capazes de imitar aquilo que está próximo ao "nosso alcance", ou seja, na Zona de Desenvolvimento Proximal. Os autores, Newman e Holzman (ibid), destacam que estudos sobre aquisição inicial da língua realizados na década de 1970 contribuem com a visão da ZDP. Observou-se que crianças não imitavam palavras que elas já conheciam ou que estavam muito além do seu nível linguístico, antes elas imitavam apenas as palavras que estavam em processo de aprender, ou seja, palavras que estavam na ZDP de cada uma delas.

As teorias e práticas contemporâneas de Vygotsky tratavam a relação entre desenvolvimento e aprendizagem diferentemente da concepção por ele adotada. Poderíamos agrupá-las em três grandes linhas de pensamento vigentes à época. A primeira considerava que desenvolvimento e aprendizagem representavam processos distintos e independentes. Basicamente, segundo esta linha, o desenvolvimento de uma criança tinha suas bases estruturadas nas leis naturais (físicas e biológicas), enquanto a aprendizagem se servia do desenvolvimento e dependia do mesmo para que a aprendizagem ocorresse. Podemos perceber que 
até hoje diversas teorias e práticas pedagógicas se apoiam nesta dicotomia. Essa visão separatista polariza a ação de cada processo, sendo que, ao que nos parece, o desenvolvimento é absoluto e não altera o seu percurso sob a ação da aprendizagem. Afinal, segundo a presente perspectiva, temos a mesma criança, dado o seu estágio de desenvolvimento, antes e após a aprendizagem. A única diferença detectada é que, ao final do processo de aprendizagem, temos uma criança "instruída", uma criança alfabetizada.

A segunda perspectiva apresenta o desenvolvimento e a aprendizagem como uma unidade. No entanto, por um lado a visão separatista impede a real discussão entre desenvolvimento e aprendizagem, na medida em que os coloca como fenômenos distintos e que se relacionam numa relação similar à relação de produção e consumo, conforme destacou Vygotsky de forma crítica: "A aprendizagem consome os produtos do desenvolvimento. Ela usa-os e aplica-os à vida".(VYGOTSKY, 1987, p.195). Por outro lado, pela perspectiva de unidade sugerida pela segunda visão, ao admitir que não há distinção entre os fenômenos de desenvolvimento e de aprendizagem, a questão que envolve as relações entre elas nem ao mesmo pode ser levantada.

A terceira visão da relação desenvolvimento-aprendizagem parece buscar uma síntese entre a perspectiva separatista e a perspectiva unitária. Uma das linhas de pensamento desta visão propõe um caráter dual ao desenvolvimento, existindo, assim, o desenvolvimento como maturação e 0 desenvolvimento como aprendizagem. Apesar de fazer críticas ao modelo apresentado, Vygotsky o vê como um modelo que mais se aproxima da rica e fecunda relação desenvolvimentoaprendizagem. Ao menos esta concebe que a aprendizagem produz determinadas alterações no desenvolvimento.

É a partir dessas críticas que o jovem psicólogo russo, sem perder de vista seu fundamento sócio-histórico-dialético, se propõe a compreender as complexas inter-relações contidas no par dialético aprendizagem-e-desenvolvimento ${ }^{16}$. Sua importante contribuição no sentido de tentar apontar de que forma a aprendizagem “impulsiona” o desenvolvimento se dá exatamente na compreensão do conceito de

\footnotetext{
${ }^{16}$ A alternância na escrita do par dialético "desenvolvimento-e-aprendizagem" ou "aprendizagem-edesenvolvimento" é proposital e intencional. Queremos assim destacar a não classificação hierárquica dos dois termos.
} 
zona de desenvolvimento proximal: "A aprendizagem é útil quando se move à frente do desenvolvimento. Ao fazê-lo, ela impele ou desperta toda uma série de funções que estão em fase de maturação repousando na zona de desenvolvimento proximal" (VIGOTSKY, 1987, p.212). É fundamental a compreensão do conceito de zona de desenvolvimento proximal na busca por uma também compreensão da formação de conceitos na estrutura cognitiva do sujeito.

A fim de não perder de vista o propósito em que estamos engajados no presente capítulo, retomamos o nosso diálogo com a psicologia do desenvolvimento proposta por Vygotsky. Buscamos apontar o papel das analogias na formação dos conceitos, no entanto, algumas questões surgem de forma pertinente: o que entendemos por conceitos? Que tipo de conceitos têm sua base na relação dialética analogia-e-categorização? Sem perder de vista tais indagações, recorremos mais uma vez a perspectiva sócio-histórico-dialética de Vygotsky.

A ZDP aparece aqui como instrumento-e-resultado fundamental na tarefa de compreender a formação de conceitos. Segundo Vygotsky, na ZDP a aprendizagem aparece conduzindo o desenvolvimento de uma criança, à medida que esta se torna capaz, assim como os adultos, de participar de atividades conscientemente em vez de apenas espontaneamente. As ideias, aparentemente duais, de espontâneo e volitivo presentes nas atividades das crianças (assim como nas atividades dos adultos) nos conduz a duas categorias de conceitos presentes na psicologia de Vygotsky, os conceitos espontâneos (ou ordinários) e os conceitos científicos (ou conceitos "escolares"). As referidas categorias não aparecem definidas formalmente, afinal a definição de categorias de forma rígida, que coloca os conceitos formados pelos sujeitos em suas atividades como resultado de suas interações com os diversos sistemas, nos pareceria fortemente contraditória com a posição metodológica assumida por Vygotsky, na qual "nada é uma coisa-em-si; neste sentido, nada é definido. Determina-se o que alguma coisa é por seus interrelacionamentos com outros sistemas, processos e conceitos" (NEWMAN e HOLZMAN, 2002, p.77).

No entanto, é fundamental compreender de que forma Vygotsky aponta a formação dos conceitos espontâneos e dos conceitos científicos. Na verdade, segundo ele, estes partem de pontos distintos e se encontram de forma dialética, 
evidenciando assim como a aprendizagem gera desenvolvimento na complexa interrelação desenvolvimento-aprendizagem. Fica claro também que sua posição difere das teorias e práticas tradicionais contemporâneas a ele, incluindo a psicologia do desenvolvimento de Jean Piaget.

É importante destacar que o uso de analogias em atividades didáticas é sem dúvida uma ação voluntária e planejada, ainda que o planejamento seja em certo grau inconsciente e quase que imediato. Agindo no referido contexto e pertencendo ao conjunto de atividades desenvolvidas no âmbito escolar, as analogias buscam auxiliar a formação dos conceitos científicos. No entanto, de acordo com a perspectiva aqui adotada, as analogias desempenham um papel fundamental também na formação dos conceitos ordinários, outrora chamados de conceitos espontâneos. Portanto, uma vez assumida a tentativa de se fazer a síntese proposta, encontramos aqui o diálogo apropriado à aproximação pretendda. Entender de que forma os conceitos científicos são formados e como eles se "comunicam" (se cruzam) com os conceitos ordinários ou espontâneos nos parece fundamental.

Quando mencionamos acima que, segundo Vygotsky, os conceitos espontâneos e os conceitos científicos têm origens distintas, o fizemos na intenção de dialogar com a presente perspectiva, segundo a qual as analogias desempenham um papel fundamental no pensamento humano. Destacamos que nossa distinção das outras espécies animais é a capacidade de representar a realidade, e que tal representação se inicia na linguagem (na língua). Se, por um lado, as analogias desempenham um papel primordial na formação dos conceitos ordinários, de forma não consciente e involuntária, por outro lado elas são utilizadas também em atividades volitivas, buscando o compartilhamento de significados entre os sujeitos envolvidos na comunicação. Tendo em vista tais considerações, as analogias estariam ligadas aos dois níveis de conceitos apontados na psicologia de Lev Vygotsky. Nesse sentido, é fundamental retomar as definições de conceitos espontâneos e conceitos científicos para Vygotsky.

Conceitos científicos estão inscritos num ambiente formal, sua relação com as crianças é intencional e estão inscritos num contexto cujo conhecimento é organizado em níveis hierárquicos. Pertencem a conjuntos de estudos mais gerais, 
como as ciências da vida, a matemática ou as ciências sociais. Possuem geralmente expressões verbais bem definidas, e isso faz com que as crianças tenham acesso primeiramente ao "conceito puro" para só depois relacioná-lo com o "objeto da realidade". Alguns exemplos de conceitos científicos seriam: causalidade, função, relevo, fóton. Em contrapartida, conceitos espontâneos são aqueles que as crianças apreendem ao curso da vida, sem sistematização ou intencionalidade, como no caso dos conceitos científicos. As crianças adquirem tais conceitos através de sua experiência "direta" com os objetos ou mediada pelos adultos. No entanto, nesse caso elas os empregam em situações do dia a dia, sem ter a consciência de que existe algo por trás chamado "conceito". Alguns exemplos de conceitos espontâneos seriam: mãe, primo, triângulo, dinheiro, futuro. Mesmo que possamos notar que conceitos como triângulo podem aparecer na experiência de uma criança de forma espontânea e que este reaparece num contexto escolar, ou seja, no domínio dos conceitos científicos, este ganha "ressignificação" associada ao seu uso e regida pelas relações ali presentes. O que na teoria da atividade, a fim de dar conta do que chamamos de ressignificação, vinculamos à comunidade, às regras e à divisão social do trabalho. No entanto, o que queremos destacar neste momento é o fato de que cada tipo de conceito possui uma relação diferente na experiência da criança. Ressaltamos ainda a relação dialética e não linear destes, a destacar, ao mesmo tempo que cada tipo de conceito, segundo a classificação aqui apresentada, tem origem distinta e manifesta aspectos opostos ao outro, estes também são manifestados de forma idêntica.

Como um exercício de compreensão e a fim de evidenciar o que acabamos de descrever, ou seja, as inter-relações entre os conceitos espontâneos e os conceitos científicos adquiridos pelas crianças, lançamos mão de considerações feitas por Vygotsky, a partir do trabalho experimental realizado por um de seus colaboradores, seu colega Shif, com crianças em séries iniciais da escola ${ }^{17}$. Tal experimento visa observar a capacidade de crianças nessa fase da vida escolar de perceber relações causais e explicativas (que utilizam a palavra "porque") assim como relações adversativas (que utilizam a palavra "embora"). Algumas frases envolviam conceitos espontâneos como "O homem caiu de bicicleta porque...", e

\footnotetext{
17 Utilizamos o exemplo presente em Newman e Holzman (2002). Apesar da citação constar em nossa bibliografia, foi a partir da leitura da obra dos autores supracitados que tivemos o primeiro acesso ao conjunto de experimentos ao qual o trbalho de Shif pertence.
} 
outras envolviam conceitos científicos tais como "A economia planificada é possível na URSS porque...". O que chama atenção são os resultados desse ensaio experimental. Na verdade estes são contraintuitivos, as crianças obtiveram melhor desempenho nas relações que envolviam os conceitos científicos. A diferença foi acentuada nas respostas dadas por crianças das séries iniciais, por exemplo da $2^{a}$ série, relativas às frases de relações explicativas. Segundo os resultados, 0 desempenho dessas crianças com as frases que envolviam conceitos científicos foi significativamente superior aos obtidos nas relações causais envolvendo os conceitos espontâneos. Em contrapartida, as mesmas crianças obtiveram fraco desempenho em ambos os tipos de conceitos nas relações adversativas. No entanto, crianças de séries um pouco mais avançadas, com maior nível de escolarização, tendo se apropriado de certos conceitos científicos, obtiveram desempenho melhor em ambos conjuntos de conceitos, mas ainda superior nas relações que envolviam conceitos científicos.

A interpretação de Vygotsky referente aos resultado obtidos pela experiência supracitada foi que:

(...) existe um nível mais alto de conscientização dos conceitos científicos do que dos espontâneos, e existe um desenvolvimento progressivo em pensamento científico que é acompanhado por um rápido aumento nos níveis de desempenho com conceitos ordinários. Isso indica que a acumulação de conhecimento leva diretamente a um aumento no nível de pensamento científico, que por sua vez, influencia o desenvolvimento de conceitos espontâneos. Isso demonstra o papel condutor da aprendizagem no desenvolvimento da criança escolarizada.(VYGOTSKY, 1987, p.168)

Os resultados dessas observações, realizadas com crianças em fase inicial de escolarização, parecem apontar no sentido dialético proposto por Vygotsky. Aqui percebemos a aprendizagem gerando desenvolvimento. Afinal, a compreensão de relações causais e adversativas aplicadas a conceitos científicos é estendida aos conceitos espontâneos. De acordo com Vygotsky (1987), como a atenção das crianças está sempre orientada para o objeto, elas operam de forma inconsciente com os conceitos espontâneos. Isso faz com que as crianças operem com tais conceitos em situações cotidianas de forma não-sistemática. Afinal estes foram 
gerados num contexto informal, prioritariamente de forma indutiva, e são aplicados de acordo com sua relação imediata.

Entender como essas duas "categorias" de conceitos se relacionam e como cada um incorpora à estrutura cognitiva do sujeito foi o ponto de partida da aproximação proposta entre as duas perspectivas teóricas aqui apresentadas. Por um lado, os conceitos espontâneos são adquiridos empiricamente e não sistematicamente, fazendo com que, de forma inconsciente, o sujeito, à medida que amadurece em sua experiência com "as coisas do mundo", incorpore em seu repertório de significados novos conceitos. Além disso, os conceitos outrora adquiridos ganham novos "status" de significados e sentidos. Por outro lado, os conceitos científicos são construídos volitivamente e com o auxílio de um adulto, ou um parceiro mais experiente, que, dentro de um sistema hierárquico, apresenta ao "novato" conceitos a partir de sua definição, ou seja, a partir de sua forma abstrata. Nesse sentido, permite-se à criança operar conscientemente com os conceitos. Uma vez que tais conceitos são adquiridos, estes buscam nas "coisas do mundo" a sua correspondência, e assim não são apenas os conceitos que vieram a ser apresentados que ganham espaço na estrutura cognitiva do indivíduo (como mais um conceito que vem aumentar o repertório de conceitos do indivíduo), mas antes todas as relações com esse novo conceito são ressignificadas. Para Vygotsky (1987), a aquisição de um novo conceito não é o seu fim, antes porém é o início de seu desenvolvimento enquanto tal.

É, portanto, a partir dessa perspectiva que aproximamos nossa perspectiva relativa ao uso das analogias na formação de conceitos. De um lado, associada à formação dos conceitos espontâneos, apontamos as analogias que desempenham um papel fundamental na formação de conceitos ordinários presentes no par dialético analogia-e-categorização. Estas, "analogamente" aos conceitos espontâneos, não são sistemáticas e tampouco constituem ações conscientes. Fariam parte do amplo e complexo conjunto de analogias chamadas "analogias que nos manipulam"18. Na verdade, segundo nossa perspectiva, as analogias que agem no nível da formação dos conceitos ordinários são elementos presentes na formação

${ }^{18}$ Os termos "analogias que nos manipulam", assim como "analogias que nós manipulamos" são empregados na obra de Hofstadter e Sander (2013). Ainda que não sejam usados exatamente conforme o emprego na presente tese, foi a partir da referida obra que nos apropriamos das respectivas expressões. 
dos conceitos espontâneos, ou seja, o par dialético analogia-e-categorização compõe a complexa estrutura dinâmica da ação do sujeito na formação destes conceitos. Por outro lado, as "analogias que nós manipulamos" estariam presentes em nossas ações volitivas e conscientes. No entanto, ressaltamos que o nível de consciência é também gradual, ou seja, mesmo as ações conscientes são mais ou menos conscientes, e isso implica a variação em nível tanto de elaboração quanto de planejamento. Tal variação apresenta-se dada a especificidade da atividade à qual estas estejam vinculadas, o que implicaria também, por exemplo, a variação do tempo empregado entre as etapas de elaboração e aplicação das analogias nas respectivas atividades.

Certas analogias são utilizadas nos discursos como procedimento criativo. De forma intencional, tais analogias buscam alcançar seu objetivo, a saber, o compartilhamento de sentido em contexto específico, lançando mão de comparações caricaturais. Segundo Hofstadter e Sander (2013), tais recursos consistem em atos cognitivos, não raros, aos quais recorremos quando criamos uma nova situação radicalmente diferente de certa situação inicial, ao menos em aparência, a fim de provocar no interlocutor certa reação de "espanto" e riso, a partir da qual o mesmo será (potencialmente) capaz compreender a semelhança entre as duas situações aparentemente sem nenhuma relação ou correspondência, a não ser pela improvável mas fértil relação criada através da analogia caricatural.

Como exemplo, reproduzimos uma situação descrita por dois amigos, Doug (de origem americana) e Emmanuel (francês):

Emmanuel e Doug estão tomando seu cafezinho habitual. "dois pingados", diz Doug ao garçom. Uma vez as bebidas servidas, ele adoça seu café, pega a colher sobre o pires e conta enquanto mexe: "Aqui na Europa, isso não causa a menor surpresa a ninguém o fato do café ser servido em xícaras de verdade, com pires de verdade e com colheres de verdade feitas de metal. Esta é a regra!"

"Com certeza!, diz Emmanuel. Não tem como ser diferente disso!"

"Era assim também nos EUA quando eu era estudante, disse Doug com nostalgia. Agora, isso mudou: em quase todos os lugares o café é servido em copinhos de papelão e a colher foi substituída por uma palhetinha de plástico ou de madeira, muito fina! Por que ninguém reclama? Seria... ehhh.. como se um turista viesse alugar uma canoa num lago e que no lugar de remos lhes déssemos dois longos dardos extremamente finos. Você pode imaginar a cena? Imagine mais ainda, que ninguém veja nada de mais nisso..." (HOFSTADTER e SANDER, 2013, p.383, tradução nossa). 
Este é um bom exemplo utilizado em discurso ordinário, mas que faz apelo cognitivo intencional. No primeiro momento Doug talvez não tenha conseguido "imprimir" no amigo o sentimento que faz apelo à falta de bom senso em servir café em copinhos de papelão e, sobretudo, em substituir uma colher de metal por palhetas de plástico ou de madeira. Ele buscou numa analogia caricatural o senso de absurdo da situação descrita.

Talvez estejamos sendo influenciado pelo exemplo aqui relatado na medida em que, muito provavelmente, já tenhamos vivido a experiência de sermos servidos em copinhos de plástico ou de papelão e mexido o açúcar ou mesmo o leite (no caso do pingado) com palhetinhas finas que podem remeter à analogia da canoa com dardos. É possível que isso nos remeta a um questionamento antes não levantado. Esse tipo de analogia tem seu papel cumprido na medida em que o sentimento de absurdo provocado por esta é remetido à situação inicial, ou seja, o locutor lança mão em seu discurso de uma analogia, em seguida, esta carrega explicitamente o sentido de absurdo e, por semelhança, este sentido é assimilado e recontextualizado na primeira situação.

O exemplo apresentado trata do uso de analogias em atividades de comunicação. Assim como em atividades didáticas, o locutor, neste caso particular, decide lançar mão de uma analogia no intuito de elucidar o seu "espanto". De forma geral, há uma intenção deliberada, um motivo que o leva a buscar elementos que facilitem a pretensa comunicação. Resumidamente, o que ele deseja é compartilhar os sentidos no seu discurso. É bem verdade que sua decisão surge no momento do discurso, e não previamente. Isso faz com que o intervalo de tempo entre a decisão/escolha da analogia a ser empregada e o seu uso seja menor do que no emprego de atividades com fins pedagógicos, que supostamente dispensam tempo na reflexão e no seu planejamento. Ainda assim tais atividades encontram um ponto de congruência no quesito uso consciente de analogias.

As duas categorias de analogias aqui descritas, a saber, "analogias que nos manipulam" e "analogias que nós manipulamos", guardam uma relação semelhante com a inter-relação entre os conceitos espontâneos e os conceitos científicos apontada por Vygotsky (1987). A semelhança aqui reivindicada se dá na medida em 
que destacamos, nas atividades volitivas de uso de analogias, o desencadeamento do par dialético analogia-e-categorização na estrutura cognitiva do sujeito, a fim de gerar ressignificação. Afinal, segundo o psicólogo russo, apesar de as "duas classes" de conceitos possuírem gêneses distintas, o movimento em sentidos contrários destes permite um "encontro" a partir do qual ambos são ressignificados. No entanto, como se trata aqui de um primeiro ensaio na tentativa de aproximar as duas perspectivas, buscamos elucidá-las a seguir.

As analogias-e-categorização estão presentes nas relações de formação dos conceitos espontâneos ou na resolução de problemas do dia a dia. Segundo a presente perspectiva, o par dialético desempenha um papel fundamental na formação dos conceitos espontâneos. Entretanto, o seu uso ocorre de forma deliberada e "involuntária", ou seja, sem a constante mediação da consciência. Por outro lado, as analogias empregadas em atividades didáticas são intencionais e buscam encontrar na história do sujeito elementos de semelhança que permitam acionar em sua estrutura cognitiva o que chamamos neste capítulo de motor na formação dos conceitos.

Aqui destacamos uma característica das analogias geralmente apontadas por aqueles que rejeitam o seu uso na comunicação de conceitos científicos, ou mesmo por seus defensores que sugerem prudência quanto ao seu emprego. Basear-se na história do sujeito é condição primeira do uso de analogias, uma vez que buscamos relações de semelhanças entre um novo enunciado e um outro pertencente ao "repertório" de significados do sujeito/aprendiz. $\mathrm{Na}$ verdade: "As analogias constituem o meio de aplicar as riquezas do nosso passado ao presente, sem ao qual cada um seria incapaz face ao mundo privado de senso: nosso pensamento é profundamente arraigado em nossas experiências do passado" (HOFSTADTER; SANDER 2013, p.317, tradução nossa). O termo "analogias que nos manipulam" ganha aqui um senso um pouco diferente na medida em que tal manipulação pode assumir também o sentido indesejado do que foi previamente planejado pelo seu autor. A "manipulação" aqui descrita é voltada ao nosso pouco ou nenhum controle dos resultados causados no interlocutor. Ainda que uma analogia tenha sido elaborada com a intenção de provocar relações entre o novo domínio e o já existente no repertório de experiências do sujeito, não temos a garantia de que essa conexão será estabelecida. As analogias são capazes de nos conduzir a 
interpretações ou conclusões absurdas e completamente diferentes daquelas esperadas.

(...) há consequências ainda mais sérias, porque uma simples analogia pode, ela mesmo, transformar a compreensão de certa situação e condicionar a maneira de percebê-la, de pensá-la ou de tomar decisões. O esclarecimento criado por uma analogia a respeito de determinada situação pode muitas vezes ser incrivelmente ofuscante, podendo até gerar impasses absolutos ou equívocos, quando a categoria criada para compreender a situação é inapropriada. (Ibidem, p.318, tradução nossa)

No entanto, se por um lado o uso de analogias é fragilizado devido à estreita relação destas com a história do sujeito (sendo este seu calcanhar de Aquiles), paradoxalmente, ao menos aparentemente, este ponto é também a fonte de seu enorme potencial criativo. Mesmo reconhecendo o conhecimento como produto do trabalho coletivo e histórico, entender como as analogias desencadeiam uma "avalanche" de relações do que se apresenta como novo para o sujeito, ancorado em sua história como indivíduo, nos permite pensar o funcionamento do pensamento criativo, na emergência do novo pensamento. Parece que, segundo a presente perspectiva, em certas situações, quando o pensamento é invadido por certa ideia fixa, o sujeito busca de forma incessante analogias em todos os eventos conhecidos, fazendo com que cada um destes se apresentem como "elemento" em potencial para o desenvolvimento daquilo que outrora não existira de forma estruturada enquanto conhecimento. Mesmo que tais "eventos" não sejam tão frequentes, quando ocorrem, representam momentos de "insights" que podem resultar em "descobertas" excepcionais.

Reforçamos o potencial do uso de analogias na formação de novos conceitos como contraponto aos problemas associados à referida atividade. $\mathrm{Na}$ verdade, nosso texto, baseado fundamentalmente na perspectiva apontada por Hofstadter e Sander (2013), considera que o par dialético analogia-e-categorização está presente em nossa estrutura cognitiva, funciona como motor na aquisição de significados e é mediador entre o sujeito e o mundo. O referido par dialético tem um papel fundamental desde a aquisição da linguagem da criança. Acima de tudo, nesse nível hierárquico de ação, as analogias agem num fluxo contínuo e não são mediadas 
pela consciência do indivíduo, o que foge ao controle do sujeito. Neste nível, então, as analogias teriam sua importância legitimada.

Por outro lado, o conjunto de atividades sobre as quais concentramos aqui nossos esforços representa o uso de analogias de forma deliberada, planejada e intencional. É então nesse nível hierárquico de atividades que reforçamos nossa colaboração. É em atividades volitivas que encontramos o problema supracitado, a saber, a tentativa do compartilhamento de significados, ou seja, ação coletiva baseada na história e nas complexas inter-relações do sujeito cognoscente. Explicitado o problema de que o uso consciente de analogias com o presente fim pode conduzir o sujeito a conclusões inesperadas, e sobretudo contrárias às previamente planejadas, parece-nos prudente evitá-las a todo custo. Afinal, se trabalhamos com atividades de ensino, sobretudo de ensino de ciências, não é razoável que utilizemos "ferramentas" que apresentem grande potencial de conclusões equivocadas.

Nosso caso é ainda mais particular em virtude de desejarmos pensar o papel das analogias na construção de conceitos associados à física quântica. Aqui a questão supracitada, na qual apontamos que o uso de analogias se apresenta como potencial elemento que conduz a interpretações absurdas, partindo do ponto de vista do planejamento, cresce em grau de cautela. No caso da física quântica em particular, existe um debate a partir do qual duas posturas epistemológicas são apresentadas. A primeira, com certa relação com a interpretação de Copenhague, aponta uma necessidade de se discutir os fenômenos quânticos a partir das medidas que são resultados das interações das entidades quânticas com os aparelhos de medidas. Ou seja, são representações de grandezas da física clássica. Lautesse et al. (2014) chamam tal perspectiva de "epistemologia conservadora". Esta refere-se aos objetos da física quântica pelo uso do vocabulário clássico. Já a segunda perspectiva entende que os fenômenos quânticos devem ser tratados a partir da ruptura com a física clássica e todas as relações que podem remeter aos conceitos clássicos. Esta segunda perspectiva, a qual os autores denominam "epistemologia inovadora", tem a ambição de pensar a teoria quântica por seus próprios conceitos e seus próprios termos. 
Mesmo na perspectiva da epistemologia conservadora, as questões que são levantadas pela física quântica são a priori sem relação direta com nossa realidade imediata ou com qualquer experiência presente em nosso repertório de relação com o mundo macroscópico. Entretanto, se admitimos a perspectiva da epistemologia inovadora, as questões relacionais são ainda mais problemáticas, na medida em que esta envolve afastamento inclusive de terminologia com a física clássica. Salientamos, não obstante, que, independentemente da perspectiva epistemológica adotada, na questão do uso de analogias em atividades didáticas, que visam apresentar conceitos e entidades do mundo atômico, há uma contradição intrínseca à atividade de "criar" analogias com o intuito de facilitar a compreensão de fenômenos quânticos. É então na tentativa de superar a presente contradição que o texto do presente capítulo se apresenta como reflexão.

De um lado, no nível intrapessoal, as analogias são aqui colocadas como parte do par dialético (analogia-e-categorização) representado como motor do pensamento humano. É por meio do fenômeno contínuo de categorização que as palavras, as expressões e as frases ganham sentido nas atividades do sujeito. Como descrevemos anteriormente, este processo incessante não está restrito aos conceitos espontâneos (ordinários), mas antes se estendem ao nível de conceitos mais elaborados (os conceitos científicos). Sendo assim, o uso de analogias já são presentes em nossas atividades cognitivas ainda que o desconheçamos. De alguma forma, esse processo permite o movimento proposto na inter-relação dos conceitos espontâneos e científicos, por outras palavras, ao mesmo tempo ocorrem o processo de generalização e o de refinamento das categorias mentais dos conceitos. $O$ que permite afirmar a legitimidade das analogias nas atividades de pensamento do indivíduo.

Por outro lado, no nível interpessoal, as analogias também se apresentam como elementos fundamentais no compartilhamento de significados. A despeito das questões aqui levantadas, que em princípio nos conduziriaa à decisão de evitá-las, principalmente em atividades em que o rigor conceitual se faz necessário, o que incluiria certamente, segundo algumas perspectivas, atividades didáticas no ensino de ciências, o fato de apontarmos o pensamento por analogias presente nas atividades de criação e na emergência do novo nas ciências permite-nos avançar e argumentar no sentido de superar a contradição supracitada. Vale reforçar que tal 
contradição não é atributo exclusivo das analogias, uma vez que, no ensino da física quântica, tem-se a intenção de comunicar conceitos deste domínio do conhecimento e para isso lançamos mão de alguma forma de representação, quer seja verbal, pictórica ou matemática. Quaisquer que sejam as formas de representação dos conceitos ou das entidades quânticas, essas devem ser "portadoras" de significados, dado que estes significados devem ser compartilhados entre os indivíduos envolvidos, no nosso caso professor/alunos, os mesmos devem ser negociados e construídos a partir de uma base comum. Mesmo partindo da perspectiva da epistemologia inovadora, algo comum (e anterior a essa atividade) deve mediar a comunicação entre os atores, ainda que seja apenas a linguagem.

É seguindo a lógica da comunicação e da construção de significados baseados em referências anteriores que apontamos a possibilidade do uso de analogias nas relações inter-pessoais. Não se trata de qualquer relação entre coisas ou conceitos, mas antes de uma relação de semelhança que nos permita associar os significados entre os dois domínios e nos garanta, num processo semelhante ao presente na construção de significados intra-pessoal, mediante a analogia-ecategorização, também num fluxo contínuo, estabelecer sentido ao que é novo. É justamente nesta relação analógica que os significados podem ser compartilhados. $\mathrm{Na}$ verdade, trata-se da interiorização de significados que foram a princípio construídos na relação exterior mediada pela analogia.

De forma semelhante ao que ocorre no processo de maturação das funções mentais superiores da criança, no qual é fundamental a cooperação de um parceiro mais capaz, as atividades didáticas com o uso de analogias devem ser coordenadas e orientadas pelo professor, este tendo plena consciência de seus objetivos e estando apto a negociar com os alunos os conceitos ali envolvidos. $\mathrm{Na}$ verdade, pensar no uso de analogias nas aulas de ciências tomando como aporte teórico a psicologia sócio-histórico-dialética de Vygotsky nos parece adequado e pertinente, na medida em que nos apropriamos do conceito de zona de desenvolvimento proximal. Tal apropriação não pretende tomar a ZDP como uma ferramenta metodológica, mas antes pretende-se incorporar as noções de inter-relações ali presentes e a partir daí pensar numa metodologia que as leve em conta. 
O conceito de zona de desenvolvimento proximal fortalece, segundo nossa perspectiva, a pertinência do uso de analogias em atividades didáticas. Afinal, ao lançar mão de uma analogia, o professor não age somente na relação entre o que o aluno já conhece e aquilo que desejamos que ele conheça. Antes, porém, as analogias se apresentam como instrumentos capazes de agir na relação do que o aluno é capaz de compreender com o auxílio do professor por intermédio do elemento-chave aqui apresentado, a saber, analogia-e-categorização. Isso reforça o potencial das analogias como instrumentos geradores de desenvolvimento-eaprendizagem, assim como elementos fundamentais na formação de conceitos.

Fica evidente, na aproximação pretendida entre a psicologia sócio-histórica de Vygotsky, que dentre outras questões apresenta a zona de desenvolvimento proximal, e a teoria do pensamento de Hofstadter e Sander, que destaca o potencial e a riqueza criadora das analogias, a importância dos professores na elaboração e condução das atividades didáticas que envolvem o uso de analogias. Entretanto, é fundamental destacar que as atividades didáticas que lançam mão do uso de analogias representam ações coletivas das quais participam diversos sujeitos. Tal pluralidade complexifica o conceito de zona de desenvolvimento proximal, passando de uma relação com o indivíduo para uma relação com diversos indivíduos.

Newman e Holzman (2002) apresentam um conceito de ZPD coletiva em vez de analisar a criação da ZDP "de um indivíduo". A fim de esclarecer a presente noção de ZDP coletiva, os autores lançam mão de exemplos de projetos de pesquisa fundamentados na referida concepção de ZDP que não se concentra na aprendizagem de indivíduos. O trabalho de Moll e Greenberg (1990), por exemplo, diz respeito a um projeto de pesquisa que visava examinar o compartilhamento social de conhecimento em famílias mexicanas numa comunidade no Arizona. Baseados nos resultados da pesquisa, os autores do projeto destacam:

Um elemento indispensável de nossa abordagem é criar conexões significativas entre a vida acadêmica e social por meio de atividades concretas de aprendizagem dos estudantes. Estamos convencidos de que os professores podem estabelecer, de maneira sistemática, as necessárias relações sociais fora das salas de aula que transformarão e melhorarão o que ocorre dentro das paredes da sala de aula. Estas conexões sociais ajudam professores e alunos a desenvolver sua consciência de sala de aula e usar as atividades de sala de aula para entender sua realidade social. (MOOL e GREENBERG, 1990, p.334). 
Apesar de o projeto de pesquisa aqui relatado estar inserido num contexto bastante particular, o que nos aproxima é a ideia de se construirem ZPDs coletivas. Apesar de o uso de analogias remeter à experiência individual do sujeito, trata-se de um sujeito com sua história construída com gêneses comuns aos outros indivíduos. Essa relação dialética indivíduo-e-comunidade vai nos permitir compartilhar sentidos e significados através signos apresentados, inclusive por meio de analogias.

No processo de elaboração ou de escolha de analogias visando a atividades didáticas, tendo sempre em mente a ideia das ZPDs coletivas, questões relacionadas ao grupo ao qual são destinadas não podem ser negligenciadas. Destacamos então que a unidade de análise proposta no sistema de atividades de Engeström é evocada como elemento potencial. Afinal, nossa proposta é pensar a atividade de uso de analogias em aulas de física quântica voltadas a alunos do ensino médio. Delimitando ainda mais nossa atividade, optamos por olhar aulas do referido tema ministradas em escolas públicas do estado de São Paulo. Tal precisão nos permite identificar características da comunidade, assim como das regras implícitas e explicitas ali envolvidas.

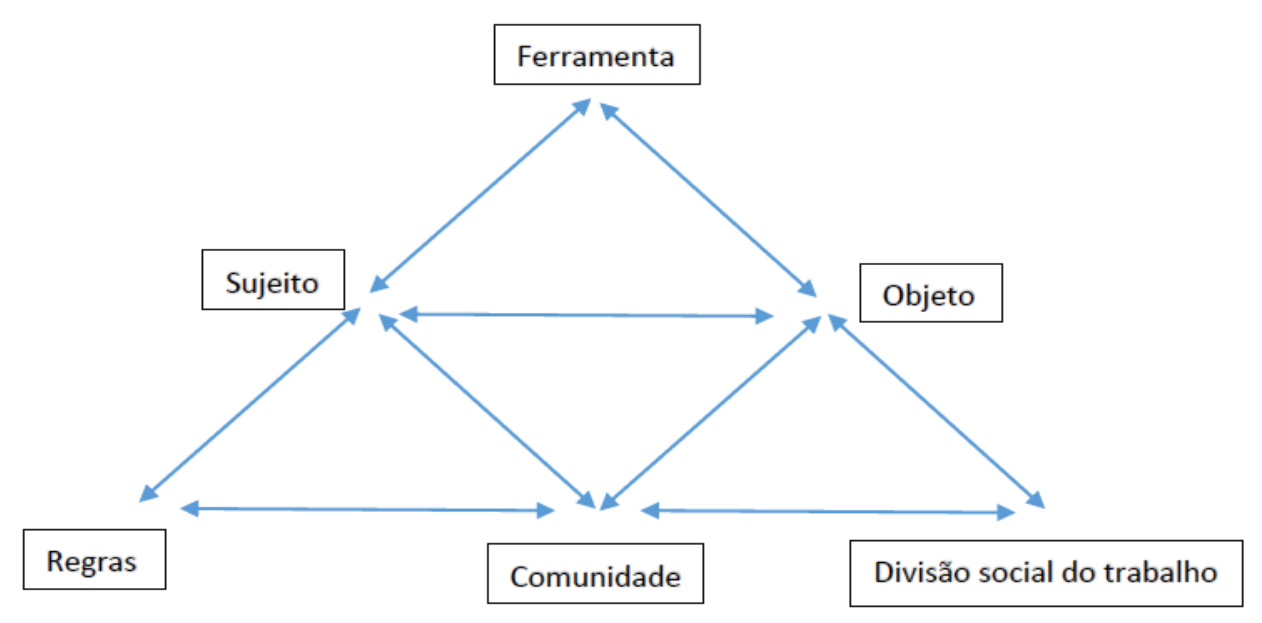

Figura 3.1 - Modelo do sistema de atividades de Engeström

Reproduzimos o modelo do sistema de atividades de Engeström a fim de facilitar a visualização daquilo que foi evocado. No entanto, por se tratar de uma teoria complexa, e por fugir aos objetivos da presente tese, o modelo do sistema de 
atividades de Engeström representado na Figura 2.1 não será explorado aqui em sua potencialidade.

Destacamos que, em atividades que incluem o uso de analogias com fins didáticos, agora numa perspectiva de ZDP coletiva, o sujeito que aparece no esquema da teoria da atividade não representa um indivíduo, mas passa a representar um coletivo. Mesmo tendo consciência da complexidade, sobretudo da pluralidade e diversidade, que consiste um dado conjunto de indivíduos, nosso foco, portanto, se dá naquilo que se apresenta como eixo comum. É, então, a partir da identificação de elementos congruentes que pautamos a elaboração e a escolha das analogias utilizadas na atividade específica. Não obstante, não se trata de definir com precisão elementos comuns ao grupo, que é diverso por constituição. Antes , salienta-se a pertinência de considerar tais elementos como potenciais colaboradores na formação dos conceitos no domínio intrapessoal.

O uso de analogias em atividades didáticas, em particular em aulas de ciências, diz respeito a ações coletivas que buscam o compartilhamento de significados de conceitos científicos. Esse compartilhamento tem sua base em conceitos outrora constituídos na estrutura cognitiva dos sujeitos participantes, e com as novas interações permitem a ressignificação do antigo, abrindo caminho para a elaboração do novo conceito. Nesse sentido, reforçamos a pertinência do uso de analogias em atividades didáticas em aulas de ciências.

\subsection{Analogias: conceitos ordinários e conceitos científicos}

O foco da presente tese está no uso de analogias em aulas de física quântica voltadas a alunos da educação básica. Reafirmamos, então, que nossa principal contribuição se dá no sentido de levantarmos a contradição (a priori) de representar as entidades do referido domínio da física e comunicar seus conceitos, na medida em que reconhecemos a falta de relação direta com nossa realidade imediata. $\mathrm{Na}$ verdade, buscam-se formas de representação compatíveis com os "objetos" da física quântica e com o nível escolar aqui proposto. 
O esforço dispensado no presente capítulo se dá na perspectiva da ampliação do domínio de atuação das analogias e, fundamentalmente, na compreensão do seu papel na formação de conceitos que não são restritos às formas mais elementares do pensamento, mas antes participam de episódios que remontam à criatividade e à intuição humana na descoberta de relações entre domínios sem semelhança aparente ou evidente. Tais episódios podem ser encontrados no vasto repertório da história do desenvolvimento do homem em suas diversas formas de representação do mundo. Em nosso caso particular, tomamos alguns exemplos do uso de analogias em atividades da ciência.

Para Hofstadter \& Sander (2013), não são poucos os exemplos de analogias presentes nas diversas áreas da Física. Elem destacam a "onipresença das analogias na Física" e afirma que estas estão presentes mesmo no cerne das grandes descobertas dos últimos séculos. Destacamos algumas, resultados de sua pesquisa:

- potencial gravitacional, análogo a uma rampa [Lagrange, Laplace, 1770];

- potencial elétrico análogo ao potencial gravitacional [Poisson, 1811];

- potencial magnético, análogo ao potencial elétrico [Maxwell, 1855];

- espaço-tempo geométrico (4-D), análogo ao espaço (3-D) [Minkowski, 1907];

- elétrons como ondas, análogos aos quanta de luz [de Broglie, 1924];

- matrizes quânticas, análogas às séries de Fourier [Heisenberg, 1925];

- ondas quânticas análogas às ondas clássicas [Schrödinger, 1926]

- comutadores quânticos, análogos aos parênteses de Poisson [Dirac, 1927];

- "isospin", análogo ao spin [Heisenberg, 1936];

- força fraca, análoga à força eletromagnética [Fermi, 1931];

- força forte, análoga à força eletromagnética [Yukawa, 1934];

- bósons vetoriais, análogos aos fótons [Yang e Mills, 1954].

Uma breve análise cronológica da lista apresentada nos permite perceber a ausência de um físico muito importante cuja contribuição marcara a Física do século XX, a saber, o físico alemão Albert Einstein. É mesmo curioso Hofstadter tê-lo 
deixado de fora de sua lista, parecendo sugerir que Einstein tenha seguido outros caminhos (talvez a lógica pura) que não a analogia no desenvolvimento de suas teorias. No entanto, vale destacar que, mais tarde, ao dedicar-se especificamente ao pensamento de Einstein, Hofstadter encontra não somente a presença de analogias no desenvolvimento das teorias "einsteinianas", como percebe no seu uso uma força quase que particular. Ao observar o desenvolvimento de suas proposições, podemos ser levados a pensar que Einstein procurava em suas associações analógicas mais do que semelhanças entre fenômenos, ele buscava uma identidade. A busca por analogias unificadoras fez de Einstein um físico destacado e abriu caminho para as novas teorias por ele apresentadas. No entanto, isso não quer dizer que Einstein as percebia como unidade desde o início, na verdade, para ele, tratava-se de analogias promissoras, mas cujas consequências eram ainda desconhecidas.

Propositalmente, buscamos exemplos do uso de analogias no desenvolvimento de teorias que tiveram seu início, fundamentalmente, no século XX, como a física quântica ${ }^{19}$ e a relatividade. Alguns exemplos, portanto, do trabalho do brilhante físico alemão são aqui apresentados. A partir destes, destacamos o papel das analogias em atividades de criação em domínios da mais elaborada complexidade. Como descreveu o grande matemático francês Henri Poincaré a respeito da criatividade científica:

Nós acreditamos, por outro lado, que eles (os cientistas) seguem passo após passo sem ter uma visão de seu objetivo que eles desejam alcançar? $\mathrm{Na}$ verdade, foi necessário que eles adivinhassem o caminho que os conduzisse a este, e por isso eles precisaram de um guia. Este guia é em princípio a analogia". (HOFSTADTER e SANDER, 2013, p. 528, tradução nossa)

A fim de reforçar a presença das analogias nas formas de pensamentos mais sofisticadas, e fundamentalmente ligadas às atividades de desenvolvimento do pensamento científico, acrescentamos à lista de analogias levantadas pelo professor de ciências cognitivas Douglas Hofstadter três exemplos de analogias presentes na elaboração de novos e revolucionários conceitos, que mudaram as bases da Física no século $X X$ :

\footnotetext{
${ }^{19}$ Ainda que alguns possam apontar o final do século XIX, com a questão da radiação do corpo negro, como o surgimento da física quântica, consideramos que a teoria quântica surge a partir da quantização da energia proposta por Einstein.
} 
- o corpo negro, análogo a um gás perfeito [Einstein, 1905];

- massa, análoga à energia [Einstein, 1905];

- gravitação, análoga à força fictícia [Einstein, 1916].

As analogias aqui apresentadas são de certa forma diferentes das presentes na lista anterior. Estas têm relações mais profundas e geralmente têm associadas a elas outras analogias. Outra característica das analogias "einsteinianas" diz respeito ao seu teor unificador, o que permite avançar e ressignificar os conceitos envolvidos. Talvez este seja o segredo dos impactos das teorias desenvolvidas por Einstein.

A primeira analogia vai culminar na teoria dos quanta luminosos e vai permitir explicar o efeito fotoelétrico, mas sobretudo vai revolucionar a Física, dando à luz um caráter corpuscular, aparentemente superado há mais de um século. No segundo exemplo, o resultado é também impactante e pode ser resumido, a partir da análise da equação $E=m \cdot c^{2}$, da seguinte maneira: “... a massa (assim como a energia) existe sob diversas formas cuja cada uma pode ser convertida em todas as outras: a massa é assim como a energia versátil e mutável" (ibidem, p. 584). A terceira analogia einsteiniana aqui apresentada diz respeito a um pequeno trecho do complexo desenvolvimento da Teoria da Relatividade Geral. Questões específicas do uso de analogias ligadas ao desenvolvimento das teoria de Einstein serão apresentadas no capítulo seguinte, onde, com o auxílio da epistemologia da ciência, buscamos elementos que permitam ampliar ainda mais nossa reflexão a respeito do papel das analogias no pensamento científico.

Buscamos no presente capítulo apresentar, de acordo com a perspectiva adotada, entender o papel das analogias na formação dos conceitos. Apontamos a presença de analogias nas diversas atividades de interação do sujeito com o mundo. Tais analogias estão presentes nas relações intrapessoais caracterizadas pelo par dialético analogia-e-categorização. Nesse nível de atuação psicológico, as analogias ocorrem sem mesmo que percebamos, ou seja, sem a mediação da consciência, e ocorrem inúmeras vezes num curto intervalo de tempo. Nossa interação com o mundo se dá, na maioria das vezes, na relação com o novo, com o desconhecido. No entanto, graças ao par dialético analogia-e-categorização, somos capazes de identificar os objetos-e-conceitos do mundo e agir a partir deles. Esse processo está 
presente desde a formação dos primeiros conceitos na vida do sujeito, em sua complexa e infinita interação na relação com conceitos ordinários.

\subsection{Algumas considerações}

Avançamos em nossa reflexão teórica e mostramos que as analogias estão também presentes nas relações interpessoais entre os sujeitos. Essa relações, diferentemente das primeiras, podem ser volitivas e planejadas. Mesmo aquelas que julgamos que foram decididas no momento da realização da atividade, nós as consideramos planejadas, ainda que em menor grau. Destacamos que as atividades didáticas que lançam mão do uso de analogias pertencem a este conjunto.

Em atividades que buscam o compartilhamento de significados, evocamos o conceito de ZDP coletiva. O objetivo é permitir, em certo grau, que ocorra o processo de analogia-e-categorização nos indivíduos envolvidos, de forma que sejam alcançados os objetivos planejados pelo sujeito que elabora a atividade analógica. Nesse sentido, julgamos fundamental partirmos da análise da atividade que leve em consideração as relações dos sujeitos envolvidos na mesma, a saber, as regras, a comunidade e a divisão social do trabalho, tendo em vista a atividade como uma ação mediada.

Como a atividade didática aqui proposta é especificamente uma atividade que tem como domínio do conhecimento a ciência, apresentamos neste capítulo alguns exemplos de desenvolvimento no pensamento científico nos quais as analogias desempenharam um papel fundamental e em alguns casos resultaram no desenvolvimento de novas e importantes teorias.

Finalmente, se as analogias estão presentes nas diversas formas de interação dos sujeitos cognoscentes, indo das formas mais rudimentares do pensamento humano e estando também presentes nas formas de pensamento mais sofisticadas nas quais incluímos teorias científicas, como a teoria quântica e a teoria da relatividade geral, não podemos negar o seu papel fundamental no pensamento humano. É bem verdade que, no campo da ciência, por exemplo, cujos conceitos têm certo grau de rigor em sua definição, sem o qual a sua compreensão é 
comprometida, algumas analogias que classificamos como "ingênuas" devem ser evitadas.

Desenvolveremos em mais detalhe a problemática das analogias na ciência no próximo capítulo. Nele, buscaremos destacar, a partir da obra de Poincaré, as caterísticas próprias das analogias neste campo do conhecimento. 
CAPÍTULO 4 


\section{ANALOGIAS E A PRODUÇÃO DA CIÊNCIA}

(...) O conceito não se opõe à realidade como um elemento estranho a ela; ele constitui, ao contrário, uma parte dessa mesma realidade, um extrato daquilo que se encontra imediatamente nela.

$$
\text { (...)O conceito é }
$$

imediatamente fornecido através da imagem concreta da qual ele faz parte(...) a aparência de valor autônomo e de independência psicológica reivindicado por ele é proveniente simplesmente do fato que nossa atenção, restrita em sua função, não pode jamais elucidar a totalidade dessa imagem e se vê obrigada a se limitar a um simples extrato. Para a análise psicológica, a consciência do conceito se reduz a consciência de uma representação ou de um elemento representativo, ligados um ao outro por associação a uma imagem verbal ou a qualquer outro signo sensível. (Cassirer, 1977,p.15 e 21) 
Seguindo a perspectiva a partir da qual refletimos a respeito do uso de analogias nas atividades de criação, o presente capítulo se apresenta como mais um elemento a partir do qual olhamos a produção da ciência e levantamos o papel das analogias nesse processo. Tentamos aqui contrapor a visão de que a analogia se constitui como uma noção vaga, flexível, polivalente e subjetiva, sendo assim aparentemente incompatível com a ciência (que de certa forma busca a objetividade), e que busca construir caminhos sem ambiguidades, através de uma dimensão intelectual voltada diretamente à racionalidade.

Como forma de organização do presente capítulo, primeiramente, apresentamos como a concepção filosófica de ciência pode rejeitar a priori ou, ao contrário, incorporar as analogias em seu processo de produção. Destacamos a perspectiva defendida por Duran-Richard (2008), na qual a autora aponta uma epistemologia que coloca os sujeitos como agentes ativos na construção da ciência e que, ao invés de "ler" as regras de uma natureza dadas a priori, elaboram as teorias a partir da negociação de significados.

No segundo momento, baseados em obras do físico, filósofo e matemático Henri Poincaré, mostramos como o raciocínio por recorrência é análogo à indução na física, e como essa analogia nos permite ascender à generalização e assim criar de leis e teoremas, sem perder o rigor matemático garantido nos processos de proposições analíticas. Ainda nesse segundo momento, apresentamos a concepção de "analogias grosseiras", presentes nas atividades quotidianas, dentre outras, mas sobretudo nestas, por não exigirem precisão nos conceitos ali envolvidos. Apresentamos também, na perspectiva de Poincaré, os dois estados de analogias presentes na Física, a saber, o primeiro que diz respeito às "analogias mecânicas", que segundo ele possuem um senso mais "fraco", por se basearem em modelos mecânicos; e o segundo estado, que seria o de "analogias matemáticas". Estas, diferentemente daquelas, experimentam relações estruturais, mais profundas, que exprimem propriedades físicas reais (Paty, 2008).

Por fim, ensaiamos uma aproximação entre as atividades de produção da ciência e de sua comunicação. Buscamos, na noção de mudança de status do senso comum apontada pelo físico e filósofo Michel Paty, a possibilidade de tornar inteligíveis alguns conceitos da FQ, e de certa forma acessíveis ao "não 
especialista". Discutimos, então, já no contexto da $F Q$, a possibilidade de inteligibilidade dos conceitos e entidades a ela relacionados. Como exemplo, apresentamos algumas discussões a respeito das interpretações da Mecânica Quântica presentes em Pessoa Jr. (2003b), e em seguida mostramos como o pensamento analógico, no senso mais profundo, foi fundamental para 0 desenvolvimento da teoria dos quanta de luz de Einstein.

\subsection{Analogias e a Produção da Ciência}

No capítulo anterior buscamos ressaltar a importância das analogias na formação de conceitos ordinários, assim como o seu papel no desenvolvimento de novas teorias científicas, como aquelas que inspiraram o físico alemão Albert Einstein no início do século XX. Iniciamos, no entanto, o presente capítulo destacando que a relação entre analogia e ciência, em princípio, pode se apresentar como incongruente. É possível, inclusive, baseado nesta "incongruência", afirmar que seria em vão tentar aproximar formas de pensamento radicalmente diferentes e até incompatíveis. Afinal, segundo algumas perspectivas, como a do filósofo francês Robert Blanché, as analogias evocam aquilo que está na ordem do senso comum ${ }^{20}$, do inócuo, enquanto o pensamento científico "segue" o rigor dedutivo. Ainda segundo esta perspectiva, as analogias remetem à noção de semelhança, sendo esta particularmente subjetiva, e seu uso no processo de desenvolvimento científico introduz noções como "incerteza" e "indeterminação", tendo estas pouca compatibilidade com a noção de ciência como um conhecimento que busca a objetivação e a universalidade. A incompatibilidade entre analogia e ciência é reforçada por Blanché ao afirmar que: "o caráter genuinamente subjetivo e incontrolável da analogia retira dela qualquer relação cognitiva”. (BLANCHÉ, 1973, p.180)

\footnotetext{
${ }^{20} \mathrm{O}$ senso comum aqui apresentado diz respeito aos conceitos e ideias culturalmente compartilhados por certo grupo mas que não têm, necessariamente, "compromisso" com qualquer rigor sistemático. Trataremos do conceito de senso comum numa perspectiva mais ampla ainda no presente capítulo. Partimos do trabalho do físico e filósofo francês Michel Paty (2003).
} 
Mesmo com todas as incompatibilidades apontadas entre os conceitos em questão, Duran-Richard (2008) ressalta que analogia e ciência estão presentes "lado a lado" em contextos de comunicação da ciência, mais precisamente em atividades de divulgação científica, e fundamentalmente quando temos a tarefa de comunicar conceitos científicos sem lançar mão da linguagem matemática ou de uma conceitualização muito específica, que não seja de fácil acesso ao público alvo.

\begin{abstract}
A analogia pretende "elucidar", ora substituindo o registro da percepção ao da explicação, ora transferindo os termos de uma teorização já elaborada ao de um outro domínio. No entanto, mesmo em termos de "divulgação" no qual este tipo de apresentação é qualificado, é bastante reveladora a desvalorização que a acompanha: ela procede de uma mudança de registro julgada inadequada voltada às exigências lógico-dedutivas do discurso científico. (DURAND-RICHARD, 2008, p.2, tradução nossa)
\end{abstract}

As atividades didáticas, quer sejam associadas às práticas dos professores ou relativas a atividades propostas nos livros e manuais escolares, pertencem ao conjunto de atividades supracitadas como de divulgação científica, na perspectiva de ter como objetivo a comunicação de conceitos científicos com restrições a elementos de representação da mesma. Por isso, é comum encontrarmos analogias como elementos mediadores no conjunto de atividades destinadas às aulas de ciências. Um exemplo, que pode ser encontrado em diversos livros didáticos de física, diz respeito à apresentação do sistema dinâmico de aceleração de uma partícula de massa $\left(m_{0}\right)$ e carga elétrica puntual $\left(q_{0}\right)$ que é abandonada $\left(v_{0}=0\right)$ no interior de um campo elétrico constante $(\vec{E})$. Ao se propor a análise de sua velocidade $v(t)$, encontramos geralmente a analogia com o sistema dinâmico da queda de um corpo $\left(m_{0}\right)$, sob ação exclusiva do campo gravitacional $(\vec{g})$, e que é generalizado a categoria do movimento de partículas com aceleração constante.

$$
v(t)=\frac{q \cdot E}{m} \cdot t \quad \Rightarrow v(t)=g \cdot t \quad \Rightarrow v(t)=a \cdot t
$$


Este tipo de analogia se enquadra na categoria das analogias unificadoras ${ }^{21}$, uma vez que a relação encontrada entre os dois sistemas físicos, por ora distintos, é estabelecida e guarda entre si uma relação de semelhança não apenas de aparência, mas antes de estrutura.

Mesmo que, para os físicos e matemáticos "incrédulos", o que acabamos de apresentar não seja uma analogia, mas dois problemas que se apoiam no conceito matemático específico, nesse caso específico no conceito de derivada, a possibilidade de submeter ao mesmo formalismo matemático dois fenômenos distintos nos parece a posteriori, de certa forma, razoável e, por muitas vezes, até esperado. No entanto, como veremos mais adiante, exemplos como a identificação entre um fenômeno termodinâmico e um fenômeno eletromagnético não seria algo "esperado", e mesmo assim a referida "analogia" constituiu o desenvolvimento da teoria dos quanta de luz de Einstein. O que ressaltamos aqui, a despeito de qualquer negação do exemplo da carga elétrica acelerada em uma região que contém um campo elétrico constante, é que as semelhanças encontradas entre domínios distintos da ciência não são dadas a priori, ao contrário, muitas vezes tal semelhança precisa ser construída numa perspectiva analógica.

Se por um lado se rejeita por incongruência a presença da analogia na ciência já estabelecida (o que chamaríamos de "ciência normal" na perspectiva Thomas Kuhn), por outro lado não são poucos os exemplos na história da ciência em que a analogia se apresenta no momento da elaboração de novos conceitos ${ }^{22}$. Ainda sob a perspectiva de rejeição e negação da possibilidade de uma relação importante entre analogia e ciência, admite-se até a existência de analogias no processo de desenvolvimento de uma teoria, entretanto, estas desempenhariam um papel heurístico sendo logo em seguida dispensadas, a fim de não comprometer a construção de uma estrutura teórica sólida.

\footnotetext{
${ }^{21}$ Este tipo de analogia encontramos geralmente no pensamento de Einstein. No capítulo anterior apontamos três das quais são reveladoras e transformadoras no sentido de aceder ao novo conhecimento, novo este que ainda estaria em seu processo de desenvolvimento. Em contraste a este tipo, encontramos outras analogias que revelam apenas semelhanças entre os fenômenos sem, portanto, conduzir à unificação.

${ }_{22}$ Citamos no capítulo anterior três exemplos de analogias presentes no desenvolvimentos de novas teorias ligados ao pensamento de Albert Einstein, a saber, o corpo negro, análogo a um gás perfeito; massa, análoga a energia e gravitação, análoga à força fictícia.
} 
Na verdade, a concepção de ciência é fundamental na aceitação ou rejeição das analogias em seu processo de desenvolvimento. Se reforçamos o teor subjetivo e ambíguo das analogias, e partirmos de uma concepção de ciência "platônica", as incompatibilidades e as incongruências são acentuadas.

\begin{abstract}
Afirmar que a ciência é um conhecimento exato pressupõe a existência de categorias conceituais invariantes e estáveis, em um mundo considerado como natural, pré-existente, onde o sujeito não intervém senão na aplicação dos métodos, os mais adequados, a sua decodificação. Esse mundo é também considerado como independente do conhecimento, e o sujeito como independente do mundo cujo discurso científico é destinado a permitir sua leitura. [...] esta imagem ficcionista da ciência tal como vemos nas teorias já estabelecidas, guarda apenas sua vontade de enunciar sua verdade inequívoca que, por ser racional, não compartilha menos com a verdade revelada a mesma reivindicação de transparência absoluta, que possa abolir ao mesmo tempo a contingência e a função simbólica de representação (DURAND-RICHARD, p.3, tradução nossa).
\end{abstract}

A partir da presente perspectiva, o uso de analogias associadas à ciência conduz exatamente ao oposto do que se espera de uma construção baseada em princípios sólidos e inequívocos. Um discurso lógico de uma filosofia que é baseada no discurso científico que se reduz à sintaxe e à semântica, reforçada pelo positivismo lógico ${ }^{23}$, parece "fugir" a qualquer elemento de subjetividade e busca construir uma linguagem perfeita a fim de corrigir as imperfeições da língua natural.

Por outro lado, já no século XIX, métodos probabilistas foram inseridos na análise de sistemas físicos, trazendo novas reflexões a respeito do determinismo e da possibilidade de previsibilidade e o papel da probabilidade nesse contexto (J. C. Maxwell, P. S. Laplace, S. Poisson, J. Fourier, C.F. Gauss). Durante o referido século, ocorre também o início da matematização das ciências sociais e biológicas (F. Galton, F. Edgeworth, K. Pearson, U. Yule, R. Fisher, J. Neyman). A abordagem estatística, que fora solidamente desenvolvida, era acompanhada de uma filosofia que inseria na relação do conhecimento do mundo variáveis como desvio, incerteza,

\footnotetext{
${ }^{23}$ Remetemos ao positivismo lógico, que data do início do século $\mathrm{XX}$ associado ao Circulo de Viena, que propõe uma filosofia da ciência que busca, dentre outras questões, demarcar o que deve ser considerado científico do não científico.
} 
probabilidade, sem que esta descrição perdesse de vista a possibilidade de se fazer inferências a respeito do sistema em questão. A partir da presente perspectiva, 0 acaso e o determinismo não são incompatíveis.

Neste sentido, Laplace menciona em sua obra "Essai philosophique sur les probabilités" que uma molécula do ar ou de um vapor descreve uma curva assim como um planeta descreve sua órbita, a única diferença entre elas diz respeito à nossa ignorância.

\begin{abstract}
A probabilidade é relativa em parte a esta ignorância, em parte ao nosso conhecimento. Nós sabemos que em três ou em um número maior de eventos, um só deve acontecer; mas nada leva a crer que um deles deva ocorrer em detrimento dos demais. Neste estado de indecisão, torna-se impossível inferir com precisão a respeito deste acontecimento. No entanto, é provável que um desses eventos tomado intencionalmente, não ocorra, porque nós encontramos vários casos igualmente possíveis que excluem sua existência, enquanto somente um lhe é favorável.

A teoria das probabilidades consiste em reduzir todos os eventos do mesmo tipo, a um certo número de casos igualmente possíveis, ou seja, assim o quanto sejamos indecisos a respeito de sua existência, e determinar o número de casos favoráveis ao evento a respeito do qual buscamos a probabilidade. A razão deste número em relação ao de todos os casos possíveis, é a medida desta probabilidade que é na verdade uma fração cujo numerador é o número de casos favoráveis, e cujo denominador é o número de todos os casos possíveis. (LAPLACE, P.S., 2009, p.7)
\end{abstract}

Segundo Durand-Richard (2008), uma teoria científica que porta um caráter exato, lógico-dedutivo só será efetiva uma vez que sejam definidas as suas condições específicas de pertinência. "Mais que refletir a essência ou a natureza dos fenômenos, ela (a teoria científica) nos faz compreender a metodologia utilizada para apreendê-los" (DURAND-RICHARD, 2008, p.4, tradução nossa).

No entanto, uma epistemologia baseada em princípios de uma ciência empirista, que visa apreender os fenômenos de uma natureza que apresenta sua "estrutura teórica" existente a priori, negligencia a participação de elementos como a hermenêutica na elaboração do discurso científico ou a própria sociologia da ciência como fatores constitutivos do processo de estruturação teórica. Tal postura epistemológica tende verdadeiramente a recusar qualquer elemento de ordem não objetiva, como é o caso, em princípio, das analogias. 
Esta, porém, não se constitui a única, ou a mais segura, forma de ação do homem no mundo. Como destaca Duran-Richard, "nesse sentido, a universalidade da ciência aparece muito mais como ambição que como dado imprescindível: ela não existe a priori, mas se constitui em si mesma no interior de um jogo de constante tensão e troca entre diferentes esferas culturais, quer sejam elas acadêmicas ou práticas, locais ou transnacionais." (idem). A análise dos enunciados das teorias científicas já estabelecidas não revela as referidas tensões e trocas. De fato, a fim de perceber o dinamismo, assim como a dimensão de historicidade, das teorias científicas a partir de seus enunciados, é necessário recorrer aos momentos nos quais a ciência aparece como um duplo processo de projeção e confrontação. É então, a partir de uma postura epistemológica que coloca os sujeitos enquanto indivíduos, a sociedade enquanto grupo histórico-cultural, e suas regras (incluindo a divisão social do trabalho), como elementos constitutivos das teorias científica, que a negociação de significados aparece como elemento pertinente, e o recurso à analogia pode ser plenamente aceito e reconhecido. Neste sentido, o que outrora seria considerado como ponto fraco ou "obstáculo epistemológico", no senso de Bachelard $^{24}$, a eliminar, na perspectiva aqui adotada, aponta que a polissemia das palavras se apresenta mais como riqueza a ser explorada, e sua capacidade dinâmica de relacionar 0 novo com 0 antigo nos parece fundamental no entendimento do papel das analogias no processo de estruturação de teorias científicas. Na verdade, a partir dessa perspectiva, as teorias científicas ganham um status de representações compartilhadas, o que vai ao encontro de nossos objetivos, fundamentalmente o de olhar a possibilidade do recurso do uso de analogias no compartilhamento de significados.

\subsection{Analogias Matemáticas Segundo Henri Poincaré}

Uma vez que percebemos que em dada perspectiva epistemológica da ciência, a despeito da não consensualidade, é possível conciliar analogia e ciência, buscamos agora, em certo grau, a possibilidade de categorização desse vasto $\mathrm{e}$ complexo conjunto que constitui as analogias. A ideia de se pensar em categorias

\footnotetext{
${ }^{24}$ Bachelard, G. , A formação do espírito científico, 2011. p. 48
} 
surge na medida em que percebemos, nas obras do filósofo da ciência francês Henri Poincaré, duas grandes categorias de analogias, a saber, as "analogias grosseiras", provenientes do pensamento primitivo, e as "analogias matemáticas", que estariam ligadas às formas de pensamentos mais elaboradas, como os pensamentos matemático e científico. Mesmo que sejamos tentados a relacionar a "analogia matemática" proposta por Poincaré àquela ligada a palavra grega $\alpha v \alpha \lambda$ o $1 \alpha$ (proporção matemática), em função do nome dado a esta categoria, as "analogias matemáticas" segundo Poincaré não se limitam à simples relação entre números ou grandezas, mas antes mantêm uma relação estrutural entre os dois domínios envolvidos no processo analógico.

Partimos, então, de questões que são levantadas no início da obra de Henri Poincaré "La Science et L'hypothèse", de 1902, na qual o filósofo francês levanta a discussão a respeito da natureza do raciocínio matemático. Já no início dessa reflexão, surge uma contradição, aparentemente insolúvel. Se, por um lado, a ciência matemática é dedutiva apenas em aparência, de onde vem o perfeito rigor reivindicado por tal ciência? De outro, se todas as suas proposições podem ser consideradas internas e seguem as regras e o rigor da lógica formal, como a matemática não é reduzida a um grande jogo tautológico? A partir da presente contradição, buscamos entender como sua lógica pode elucidar o conceito de analogia matemática aqui proposto.

Para Poincaré, o raciocínio matemático, puramente analítico, não se constitui uma demonstração. Antes, este se apresenta como uma verificação.

A verificação se diferencia precisamente da verdadeira demonstração porque ela é estéril. Ela é estéril porque a conclusão é apenas a tradução das premissas em uma outra linguagem. A verdadeira demonstração é, ao contrário, fecunda porque a conclusão the é, em dado sentido, mais geral que as premissas. (POINCARÉ, 1992, p.20, tradução nossa)

A partir de algumas considerações, pretendemos apresentar em que perspectiva Poincaré propõe certa aproximação entre a epistemologia matemática e a epistemologia física. Ele propõe a existência de relação analógica entre os processos de generalização na Matemática e na Física. Tal perspectiva é construída 
a partir de seu conceito de demonstração por recorrência. Para Poincaré, essa não é uma tarefa simples e não se trata de uma demonstração qualquer:

"Nós devemos excluir de início a geometria onde a questão se complica com problemas árduos relativos ao papel dos postulados, à natureza e à origem da noção de espaço. Por razões semelhantes não podemos nos direcionar à analise infinitesimal. É necessário então buscar o pensamento matemático ao qual ele se mantém puro, ou seja na aritmética." (POINCARÉ, 1992, p.21, tradução nossa)

Ele ainda destaca que é no início da aritmética que encontraremos o que procuramos, afinal é nas demonstrações dos teoremas mais elementares que evidenciaremos a demonstração por recorrência, visto que em teorias dos números mais elaboradas as noções matemáticas mais primitivas já foram exaustivamente exploradas.

A fim de demonstrar regras de adição e de multiplicação, podemos utilizar a demonstração por recorrência. Ao estabelecer de início um teorema para $n=1$, podemos mostrar, a seguir, que se ele é verdadeiro para (n-1), ele será também verdadeiro para $n$, logo concluímos que ele é verdadeiro para todos os números inteiros. Isto nos permite "avançar" da aritmética à álgebra. Partimos de verificações analíticas, singulares (particulares), a demonstrações sintéticas, gerais (universais). Então o que há de essencial no raciocínio por recorrência é que ele consegue condensar em uma única fórmula uma infinidade de silogismos. No entanto, é importante destacar que a verificação analítica permanece em cada passo do desenvolvimento, é aí então que reside o rigor de cada caso particular. Ao mesmo tempo, o desenvolvimento da matemática é garantido pela demonstração por recorrência, afinal, como foi levantado anteriormente, se a matemática fosse pautada exclusivamente na lógica formal analítica, esta não passaria de um grande conjunto de silogismos. Estamos, portanto, no curso de resolver a contradição apontada no início do presente tópico, e de perceber como a epistemologia poincareana explica a coexistência do rigor matemático e de seu desenvolvimento.

Lançamos mão de uma analogia a fim de demonstrar de forma simples o raciocínio por recorrência. Tomemos a imagem de uma sequência infinita de dominós e imaginemos que estes são dispostos na vertical e que as distâncias que os separam sejam iguais e previamente determinadas, ao longo de sua distribuição. 
De forma a aplicar o raciocínio por recorrência, é preciso que esta sequência de dominós atenda às duas condições a fim de que possamos afirmar que qualquer peça do dominó $D_{n}$ vai cair:

1. O dominó $\mathrm{D}_{0}$ deve cair;

2. Qualquer que seja o dominó $D_{p}$, se este cai o dominó que o sucede $D_{p+1}$ também deve cair.

Para concluirmos uma sequência de quedas das peças de dominó, é necessário que as duas condições acima sejam satisfeitas. Sendo assim, saímos de uma situação observacional limitada (a primeira peça $D_{0}$ cai, isso implica na queda da segunda peça $D_{1}$, o que implica na queda da terceira $D_{2}, \ldots$ ), ligada à experiência, e passamos a uma situação geral, na qual afirmamos que, dadas certas condições, qualquer peça $D_{n}$ cai. $O$ raciocínio por recorrência nos leva à indução matemática.

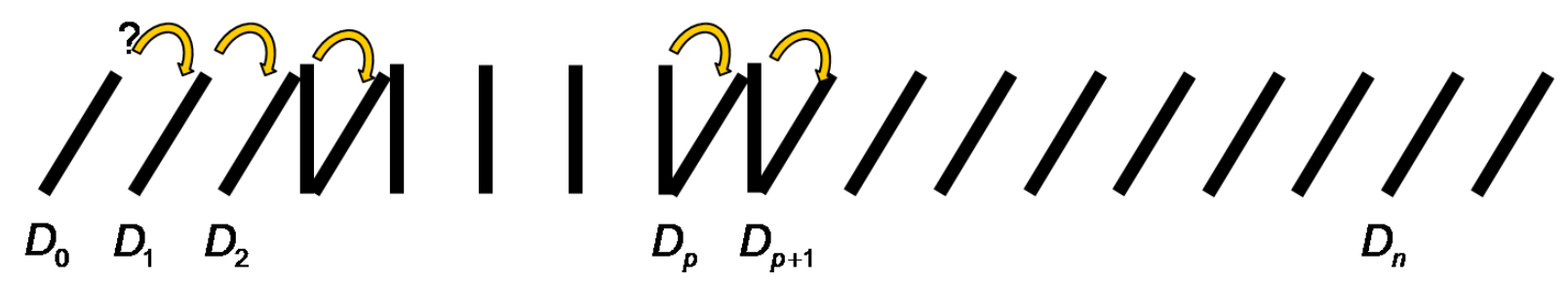

Figura 4.1 - Esquema de sequência de peças de dominó

Um exemplo simples do raciocínio por recorrência pode ser a verificação da validade da expressão que permite encontrar a soma dos primeiros números naturais diferentes de zero:

$$
S_{n}=1+2+3+\cdots+n=\frac{n(n+1)}{2}
$$


Usando o raciocínio por recorrência, a fórmula deve inicialmente ser válida para $S_{1}$. Temos então $S_{1}=\frac{1(1+1)}{2}=1$. Em seguida podemos provar que se a fórmula é válida para $n-1$ ela será válida para qualquer valor $n$.

Para $n-1$, temos:

$$
S_{n-1}=\frac{(n-1) \cdot(n-1+1)}{2}=\frac{(n-1) \cdot n}{2}
$$

Como $S_{n}=S_{n-1}+n$, temos:

$$
S_{n}=\frac{(n-1) \cdot n}{2}+n=\frac{n^{2}-n+2 n}{2}=\frac{n^{2}+n}{2}
$$

Logo:

$$
S_{n}=\frac{n \cdot(n+1)}{2}
$$

Segundo Poincaré, é graças ao raciocínio por recorrência que temos condições de passar do finito ao infinito. $\mathrm{Na}$ verdade, a ideia de infinito em matemática tem um papel preponderante, e sem tal ideia não poderíamos "aceder" ao que denominamos como ciência, pois estaríamos presos a casos particulares sem a possibilidade de generalização. No entanto, destacamos que este tipo de raciocínio não pode surgir da experiência somente, afinal a experiência nos impõe uma limitação em sua análise, a saber, ainda que a experiência possa "nos apontar" uniformidades dentro de um conjunto maior ou menor de fenômenos, esse conjunto será sempre finito, o que nos permite aplicar as "regras de uniformidade" sempre dentro de um conjunto limitado, caracterizando assim casos particulares. Se 
desejamos construir "regras gerais" ( Leis, teoremas, princípios, ...), estas devem ser generalizadas a fim de que possamos pensar na elaboração da ciência.

Apesar de mencionarmos que o raciocínio por recorrência "conduz" à indução matemática, é importante destacar a diferença entre os dois processos. Poincaré afirma que, assim como a experiência não pode legitimar o raciocínio por recorrência, a indução tampouco pode. A indução tem o mesmo título que toda lei física que está baseada em observações cujo numero é grande o suficiente, mas que assim mesmo é limitado. Logo, quer seja em Matemática ou em Física, a indução, por partir de experiências, e por se tratar de um pensamento analítico, não pode legitimar o raciocínio por recorrência porque, segundo Poincaré, este se refere ao julgamento sintético a priori.

Poincaré destaca que há uma analogia notável entre os processos habituais de indução, mas que há uma diferença essencial entre elas. " A indução aplicada à Física é sempre incerta, porque ela se baseia na crença da existência de uma ordem geral no Universo, ordem esta que está fora de nós. A indução matemática, ou seja, a demonstração por recorrência, se impõe ao contrário, necessariamente, porque ela é apenas a afirmação de uma propriedade do pensamento em si mesmo." (POINCARÉ, 1992, p.31, tradução nossa)

O pensamento de Poincaré, que descrevemos até o presente momento, é concernente à epistemologia matemática. Entretanto, é a partir da analogia entre a demonstração por recorrência e a indução na Física, na perspectiva poincarreana, que pretendemos apresentar uma epistemologia da ciência de uma forma geral e não apenas limitada à matemática. Mesmo reconhecendo as diferenças entre os dois processos, Poincaré destaca que, em matemática, busca-se sempre a generalização em detrimento da particularização, o que ocorre também na Física. "Sem dúvida o raciocínio matemático por recorrência e o raciocínio físico indutivo são baseados em fundamentos diferentes, mas seu caminho é paralelo, eles vão no mesmo senso, ou seja do particular ao geral" (idem). A "transposição epistemológica" do domínio da matemática à física se dá no sentido que compreendemos, no senso de Poincaré, a analogia entre o raciocínio por recorrência e o processo de indução. Avançamos então no sentido de afirmar que a analogia, de acordo com a perspectiva poincareana, permite o processo de 
generalização, quer seja na criação de uma lei física assim como no caso de uma lei matemática.

Poincaré vê na relação entre a matemática e as ciências físicas uma "relação de dupla colaboração". Poderíamos incluir a astronomia no conjunto aqui denominado por ciências físicas, no entanto, o filósofo e matemático francês concebe a esta última um status de contribuição privilegiado. Segundo Poincaré, foi a astronomia que nos ensinou que há leis na natureza.

Os caldeus, os primeiros que olharam o céu com alguma atenção, bem viram que aquela quantidade de pontos luminosos não era uma multidão confusa, errando ao acaso, mas antes um exército disciplinado. Sem dúvida, as regras dessa disciplina Ihes escapavam, mas o espetáculo harmonioso da noite estrelada bastava para lhes dar a impressão de regularidade, e isso já era muito. Aliás, Hiparco, Ptolomeu, Copérnico e Kepler discerniram essas regras, é inútil relembrar que foi Newton que enunciou a mais antiga, a mais precisa, a mais simples, a mais geral de todas as leis naturais.(POINCARÉ, 1995, p.103)

Entretanto, é nessa relação de dupla colaboração entre a matemática e as ciências físicas que vamos encontrar as analogias de nosso interesse. Como destacamos anteriormente, Poincaré propõe uma primeira classificação de analogias na qual ele busca apontar as "analogias grosseiras" como não pertencentes às atividades de desenvolvimento da ciência. Segundo ele, "o homem primitivo só conhece as analogias grosseiras, aquelas que impressionam os sentidos" (ibdem, p.93), e portanto são inadequadas à construção do conhecimento científico. A segunda categoria de analogias, as "analogias matemáticas", pertenceriam ao grupo de analogias presentes no domínio da física ${ }^{25}$, portanto, as analogias na física estariam classificadas em "analogias mecânicas" e "analogias matemáticas". Para Poincaré, as relações importantes nas analogias de fato, aquelas que servem ao pensamento científico, são as de natureza estrutural. Segundo ele, são elas responsáveis por fazer emergir as semelhanças mais profundas, aquelas que estão escondidas na aparente diferença.

\footnotetext{
${ }^{25}$ Aqui nosso foco é o desenvolvimento das teorias físicas, visto que este é nosso enfoque assim como foi a abordagem de Poincaré na qual os exemplos por ele analisados pertencem ao domínio da física.
} 
O primeiro estado de analogias presentes na física, conforme já mencionamos, diz respeito às "analogias mecânicas". Estas, diferentemente das "analogias grosseiras", superam as frágeis relações de aparência, apresentam relações de estrutura, mas estão apoiadas em modelos da mecânica. Paty (2008) chama a atenção para as concepções mecanicistas assumidas fundamentalmente pelos físicos do século XIX, e apresenta uma possível classificação de tais concepções de acordo com o filósofo Abel Rey. Segundo Rey (1907), são três as escolas relacionadas às concepções mecanicistas supracitadas: a primeira, denominada "conceitual" ou "energética"; a segunda, que, baseada na intuição empírica, lança mão de "esquemas mecânicos" com fins de representação, sem, no entanto, atribuir a estes valor ontológico concernente à realidade física, denominada "escola crítica", na qual poderíamos encaixar o filósofo e matemático francês Henri Poincaré; e a terceira, esta sim considerada como "escola mecanicista", na qual tiveram grande destaque físicos como William Thomson e em certa medida James Clerk Maxwell.

Como afirma Paty, apesar de Abel Rey não discursar em termos do papel das analogias na formação do pensamento científico, este último faz uma distinção entre as três escolas aqui mencionadas, em sua relação com os elementos figurativos tomados da mecânica, a fim de representar o movimento:

Nas teorias físicas, a escola conceitual ou energética não admite jamais - a escola crítica admite como acessório - a escola mecanicista admite sempre e de uma forma essencial, elementos figurativos, tomados da representação do movimento. (REY, 1907,p.48, tradução nossa)

Conforme destacado acima, as duas últimas escolas assumem em sua epistemologia a utilização de elementos figurativos, o que chamaremos de forma aproximativa de "analogias mecânicas". Paty (2008) destaca que, para William Thomson, compreender em física seria na verdade ser capaz de construir um modelo mecânico correspondente. Se primeiramente a analogia remete à elaboração de um modelo mecânico, esta pode ser seguida de "outra analogia mais profunda como aquela entre a propagação de calor e os fenômenos elétricos sugeridos pelo mesmo Thomson a partir de 1842". Ainda no nível das "analogias mecânicas", identificamos, nos resumos das aulas de Eletricidade e Óptica 
ministradas na Universidade Sorbonne entre 1888 e 1890 por Poincaré, exemplos de uso do referido recurso. O epistemólogo francês apresenta a Teoria eletromagnética da luz partindo da ideia de que o éter e o fluido de Maxwell no fundo desempenham o mesmo papel. Poincaré destaca, por exemplo, que a impressão causada por um feixe luminoso em nossa retina é na realidade resultado da oscilação periódica do campo eletromagnético.

Uma das consequências mais importantes desta teoria [ teoria proposta por Maxwell para explicar o Eletromagnetismo e a indução], [...] é a identidade de propriedades essenciais do éter segundo Fresnel, que transmite as radiações luminosas, e do fluido que Maxwell supõe presidir às ações eletromagnéticas. Bem como permite observar este último, esta identidade de propriedades é uma confirmação de um fluido que serve de veículo à energia. (POINCARÉ, 1901, §175)

Preencher o espaço com um novo meio toda vez que devemos explicar um novo fenômeno não seria assim um bom proceder filosófico; ao contrario, se, tendo chegado independentemente, pelo estudo de dois ramos diferentes da ciência, à hipótese de um meio, as propriedades que devemos atribuir a esse meio para perceber que afinal fenômenos eletromagnéticos se apresentam da mesma natureza que aqueles aos quais devemos atribuir ao éter luminoso para explicar os fenômenos da luz, as razões que temos de acreditar na existência de um mesmo meio serão seriamente confirmadas." (MAXWELL, apud POINCARÉ, 1901 §175)

Mesmo reconhecendo que tais analogias ditas "figurativas" não estejam no mesmo estágio das analogias no senso mais forte, de relação estrutural mais profunda, como as "analogias matemáticas", as "analogias mecânicas" como as supracitadas, encontram-se classificadas por Poincaré como pertencentes ao conjunto de analogias presentes na formação do "verdadeiro" pensamento científico. Diferentemente da sua postura diante das "analogias grosseiras", ele admite que tais analogias, as "analogias mecânicas" (figurativas) podem servir se base, ou seja de ponto de partida, para as analogias "mais profundas, estruturais, matemáticas, que exprimem as propriedades físicas reais." ${ }^{26}$

\footnotetext{
${ }^{26}$ Essa passagem corresponde, na historia da física, àquela de uma mecânica de forças centrais (a mecânica newtoniana) a uma física de princípios, que é analítica : a física matemática no sentindo em que ele entendende, lagrangiana e hamiltoniana. (PATY, 2008, p.177)
} 
Percebemos certa herança dessas "analogias mecânicas" em algumas práticas de professores, nos livros didáticos, assim como em trabalhos que versam a respeito do uso de analogias em aulas de física. Encontramos, na obra "La théorie de Maxwell et les oscillations hertzienne", de Poincaré, alguns exemplos aos quais nos referimos como possível herança percebida em nossas práticas didáticas atuais. Nesta obra, podemos encontrar analogias como a relação entre o equilíbrio eletrostático entre dois condutores e o equilíbrio hidrostático entre dois recipientes contendo água e interligados por um tubo; encontramos também a relação entre a resistência de um fio metálico com o atrito no interior de um tubo que interliga os reservatórios, como o do exemplo anterior; e a comparação da auto-indução elétrica como um tipo de inércia ${ }^{27}$.

Mesmo assim, o filósofo e matemático francês não se priva de destacar que tais formas analógicas de explicação, que buscam paralelismos entre as leis da eletrodinâmica, como os princípios da dinâmica, não podem ser conclusivas na medida em que estes se constituem modelos particulares. Poincaré se questiona se não seria em vão, ou perda de tempo, empenhar-se na busca por uma explicação mecânica completa para os fenômenos elétricos.

Se ela [a escolha por um modelo particular da dinâmica] portasse apenas uma solução, a possessão desta única solução, que seria a verdade, seria pagar caro demais. Mas se ela não é assim: chegaríamos sem dúvida a criar um mecanismo de imitação mais ou menos perfeito dos fenômenos eletrostáticos e eletrodinâmicos. Mas se somos capazes de imaginar um, podemos imaginar uma infinidades de outros. Além disso, não parece que qualquer dentre eles se impõe até aqui à nossa escolha por simplicidade. Portanto, não percebemos com clareza porque um dentre eles nos faria, melhor que os outros, penetrar o segredo da natureza. (POINCARÉ, 1899, p.5, tradução nossa)

Para ele, as descrições particulares dos modelos mecânicos foram importantes para a elaboração da teoria do eletromagnetismo. Tais relações com os modelos mecânicos estavam presentes nos primeiros trabalhos de Maxwell e serviram de base para o que Paty (2008) chama de indução (para o pensamento), e

27 Em nossa comparação, a auto-indução se explica facilmente. Parece que para colocar a eletricidade em movimento temos que superar uma resistência contra-eletromotriz, mas que uma vez iniciado o movimento, ele tende a se manter. A auto-indução é portanto um tipo de inércia. (POINCARÉ, 1899, p.11, tradução nossa) 
graças à "física matemática", na forma da mecânica analítica, foi possível explorar de forma profunda, encontrar as relações estruturais da realidade física, e não se limitar aos casos particulares outrora percebidos por meio das "analogias mecânicas". De fato, na elaboração de uma teoria física, no senso de Poincaré, as analogias "figurativas" têm a sua importância mas não se esgotam em si mesmas. A fim de que estas desempenhem seu verdadeiro e pertinente papel, devem ultrapassar os casos particulares e conduzir, assim, às analogias mais profundas, a saber, as "analogias matemáticas".

Para Poincaré, a função da "analogia matemática" é conduzir ao processo de generalização, pois é graças à forma matemática que relações profundas escondidas nas aparentes divergências podem emergir. Enquanto as "analogias mecânicas" permitem um paralelismo particular, as "analogias matemáticas" garantem, por uma extensão criadora, passar do particular ao geral.

Poincaré (1995) levanta uma questão por demais pertinente: "Mas como generalizar?", afinal são diversas as formas que poderíamos propor a fim de passar de experiências particulares à generalização. No entanto, revisitando a discussão apresentada anteriormente, é baseado no processo de recorrência que sugerimos que a generalização provém da analogia, mas não se trata aqui da analogia ao senso das "analogias grosseiras". Afinal, como destaca Poincaré, "quem nos ensinou a reconhecer as analogias verdadeiras e profundas, aquelas que os olhos não veem, e que a razão não adivinha? $\mathrm{O}$ espírito matemático, que desdenha a matéria, para só se ater à forma pura. Foi ele que nos ensinou a chamar pelo mesmo nome seres que só se diferem pela matéria [...]." (POINCARÉ, 1995, p.92)

Tomemos, então, o exemplo das ondas sonoras. Utilizamos a mesma palavra para nos referir a outros fenômenos, como as ondas que se propagam na superfície de uma piscina, ou relacionados às ondas eletromagnéticas. Mesmo que identifiquemos que as ondas sonoras são longitudinais, enquanto ondas que se propagam na água são transversais, utilizamos a mesma palavra porque ambas podem ser descritas pelo mesmo formalismo matemático, o que chamamos de equação de onda. Então afirmamos que o termo "onda", por analogia, generaliza uma propriedade comum a um conjunto de experiências físicas. A equação de onda generaliza uma propriedade matemática comum. 
Finalmente, a noção de "analogias matemáticas" permite à física se apropriar do formalismo matemático na busca da exatidão, da precisão e do rigor os quais não podem ser adquiridos por meio das experiências, ausentes nas propriedades físicas destas obtidas. Portanto, as analogias se constituem o único meio pelo qual o raciocínio por recorrência pode transpor as etapas da criação de leis matemáticas e, assim, alcançar a formulação de leis físicas e com isso a construção do conhecimento científico.

Antecipamos uma discussão que será retomada no próximo capítulo, a fim de destacar que tentamos aqui fazer uma breve síntese do papel das analogias na construção das teorias físicas. No entanto, lembramos que, na presente tese, buscamos contribuir com o repertório de trabalhos que procuram entender a importância do uso de analogias em atividades de ensino. Nesse sentido, destacamos que o grau de rigor apresentado por Poincaré não corresponde ao nosso, visto que é evidente que as atividades didáticas diferem das atividades de produção da ciência. No entanto, mesmo tendo ciência de tais distinções, lançamos mão no presente capítulo da perspectiva epistemológica de Henri Poincaré, e tentamos certa aproximação com nosso objetivo, na medida em que compartilhamos com este o domínio ao qual nos dedicamos, a saber, a física. Dito isso, não vimos nas "analogias mecânicas" somente uma ferramenta para se alcançar o grau de generalização das "analogias matemáticas".

$\mathrm{Na}$ verdade, como nosso maior interesse é refletir a respeito do uso de analogias em atividades didáticas voltadas a aulas de física quântica, direcionadas a alunos da educação básica (talvez alunos do terceiro ano do ensino médio), nossas questões são bem particulares. Para Paty (2003), trata-se de um domínio da física cujos conceitos não possuem relação direta com o mundo macroscópico, e com isso "distante" dos fenômenos da física clássica, física esta "vivenciada" e estudada até então; e trata-se também de um domínio cujo formalismo matemático, em princípio, não corresponde ao nível educacional em questão. Portanto, essas duas particularidades aparecem na relação entre as duas categorias de analogias pertencentes à física, na perspectiva poincareana. Ou seja, de um lado as "analogias mecânicas" buscam, como elementos figurativos, modelos mecânicos, em princípio incompatíveis com a física quântica; por outro lado, as "analogias 
matemáticas" garantem uma relação de estrutura mais profunda, mas, em nosso caso particular, essas estruturas podem fugir ao "repertório" de nossos alunos.

É então, na tentativa de "resolver" a contradição do uso de analogias no domínio da física quântica, voltada ao referido segmento educacional, que buscamos na concepção de mudança de "status" do senso comum, apresentada por Paty (2003), a possibilidade de apontá-las como pertinentes em nosso contexto, ainda que não seja este o objetivo da presente tese. Tais discussões reaparecem nas considerações finais da presente tese.

\subsection{A Ciência em seu desenvolvimento e sua comunicação}

Buscamos de certa forma compreender a relação entre a produção da ciência e sua comunicação. Destacamos, portanto, que há, em princípio, dois níveis de comunicação daquilo que é/foi desenvolvido no campo da ciência. O primeiro diz respeito ao caráter social de todo conhecimento humano, estando neste incluído o conhecimento científico. Além do aspecto histórico e social do desenvolvimento da ciência, destacamos aqui o seu caráter social. Em todas as épocas, mas sobretudo nas eras Moderna e Contemporânea, a consolidação de uma teoria passa pela comunicação entre pares. Isso significa que, mesmo que uma teoria científica seja desenvolvida "individualmente", esta deve ser compreendida por outros sujeitos que compõem a comunidade científica. Um novo conhecimento é validado desde que este esteja, de certa forma, inserido no conjunto de conhecimentos até então produzidos, mesmo que venha de encontro aos demais. Este nível de comunicação ocorre entre especialistas daquele domínio da ciência ou de domínios afins. O segundo nível de comunicação ocorre entre especialistas, ou um representante do mesmo ${ }^{28}$, e leigos. Qualquer atividade de divulgação da ciência lança mão do referido nível de comunicação. As atividades dos professores de ciências também se enquadram no segundo nível de comunicação. Mesmo estes, os professores, não

\footnotetext{
${ }^{28} \mathrm{Na}$ medida em que entendemos a pluralidade de meios de divulgação científica, percebemos que grande parte destes não tem diretamente a presença do especialista, ou seja, do cientista, mas antes este é representado por um sujeito responsável pela comunicação dos conceitos ali envolvidos. No teatro e no cinema esse papel é desempenhado pelos atores, nos museus são os monitores que representam o especialista.
} 
sendo na maioria das vezes os responsáveis diretos pela produção da ciência, são eles os seus comunicadores.

Vale, no entanto, destacar que a produção da ciência e a comunicação desta a alunos nos diversos níveis do ensino representam atividades distintas.

Para Chevallard (1991), a relação didática coloca o saber entre o professor (aquele que ensina) e o aluno (aquele que aprende). Especificamente nas atividades didáticas, o autor francês destaca o saber como "saber ensinado". Já o conhecimento produzido nas atividades do cientista e do matemático, por exemplo, é por ele denominado "saber sábio". Portanto, trata-se de conteúdos de conhecimentos distintos, transformados pelo processo da transposição didática. "Um conteúdo de saber tendo sido designado como saber a ensinar é submetido por conseguinte a um conjunto de transformações adaptativas que vão torná-lo apto a ocupar lugar entre os objetos de ensino. O "trabalho" que faz de um objeto de saber a ensinar um objeto de ensino é chamado de transposição didática”. (CHEVALLARD, 1991, p.39)

Mesmo em concordância com o fato de que os "dois saberes" supracitados se constituem como saberes distintos, nossa perspectiva se aproxima mais da ideia de recontextualização. Os discursos, os textos e as representações em cada contexto são distintos, entretanto as atividades didáticas representam mais do que uma transposição como descrita por Chevallard, são antes constituídas de novos atores, novas regras sociais, e fundamentalmente possuem fins distintos. Como destacamos anteriormente, segundo Leontiev (1978), toda atividade tem em sua condição primeira uma necessidade, esta, portanto, encontra sua determinação no objeto, e é este que se torna motivo da atividade, ou seja o que a estimula ${ }^{29}$.

(...) na perspectiva da recontextualização, o foco é estudar a transferência dos textos entre diferentes contextos de produção e reprodução, mediada pelas relações de poder e pela regulação do discurso de ordem social: há aqui a produção de um discurso com características de discurso recontextualizador, 0 discurso pedagógico, sendo que o discurso regulatório se sobrepõe ao instrucional.

\footnotetext{
${ }^{29}$ No caso dos professores, o significado do seu trabalho é formado pela finalidade da ação de ensinar, isto é, pelo seu objetivo, e pelo conteúdo concreto efetivado através das operações realizadas conscientemente pelo professor, considerando as condições reais, objetivas na condução do processo de apropriação do conhecimento do aluno. (BASSO, 1994, p. 27)
} 
Desse modo, uma das principais diferenças entre a transposição didática e a recontextualização, a meu ver, está na compreensão do papel da "ordem social" na transformação do conhecimento científico e na produção do saber a ser ensinado e do discurso pedagógico. (MARANDINO, 2004, p.104)

Não sendo o nosso objetivo principal o de confrontar o conceito de transposição didática com o de recontextualização, pretendemos aqui reforçar as diferenças entre as atividades de produção do conhecimento e as atividades voltadas ao ensino. No entanto, ainda que representem atividades distintas, no caso específico das ciências, os conceitos envolvidos nas duas atividades são comuns, mesmo que ganhem sentidos diferentes nos diferentes contextos. É então a partir dessa perspectiva que buscamos elementos que sejam comuns aos dois distintos contextos, de forma que sejam possíveis algumas contribuições visando ao ensino.

\subsubsection{Um novo "status" do senso comum}

Uma vez que constatamos a comunicação, entre pares, dos conceitos e das entidades nos diversos campos da ciência (mesmo no domínio da física quântica), propomos uma análise das "ferramentas" de comunicação, assim como dos processos de aproximação do que se deseja comunicar como novo conhecimento. Nossa tentativa está baseada, principalmente, nas reflexões do físico e filósofo francês Michel Paty. Em seu trabalho "A ciência e as idas e voltas do senso comum", Paty (2003) aponta questões relacionadas ao status do senso comum e discute conceitos como o de racionalidade e inteligibilidade. Ainda que o ensino não seja sua preocupação, julgamos pertinentes as contribuições do trabalho, que discute a possibilidade de comunicação de conceitos da Física Quântica a não especialistas. Partimos então de uma aparente contradição, a partir da qual: "Não podemos conceber a compreensão ou a comunicação sem fazer referência ao senso comum, que é uma espécie de terreno fértil para nosso pensamento e nossas ações. Porém, por outro lado, não existe possibilidade de aparecimento de novos conhecimentos de uma certa importância, sem ultrapassar o senso comum e, portanto, sem romper com ele." (PATY, 2003, p.9)

Para Paty (2003): "o senso comum é uma disposição geral de todos os seres humanos para se adaptar às circunstâncias da existência e da vida ordinária. (PATY, 
2003, p.10). Ele ainda destaca que: 'Na expressão 'senso comum', a palavra 'senso' se refere a uma espécie de síntese instintiva (mas também intuitiva) imediata, enquanto o termo 'comum' indica o caráter ordinário, difundido, provavelmente generalizado, dessa faculdade" (idem).

O referido artigo trata a noção de senso comum com o cuidado da terminologia, assim como evocando o seu sentido polissêmico. Senso comum pode estar relacionado à opinião comum, construída historicamente na concepção de uma determinada cultura. Pode, nesse sentido, estar ligado à ideia de senso compartilhado por certo grupo cultural e que the permite julgar e tomar decisões. Como é também destacado por Paty (2003), pode ser entendido como "bom senso", entendido como razão de acordo com a afirmação de René Descartes no Discurso do Método: "A capacidade de bem julgar e de distinguir o verdadeiro do falso, que é prioritariamente o que denominamos 'bom senso' ou razão, é naturalmente igual em todos os homens" (Descartes, 1996, p.2).

Se para Descartes a expressão "senso comum" foi tomada como base para nossos julgamentos racionais, em contrapartida, fundamentalmente na segunda metade do séc. XIX e no séc. XX, esta é tida como as concepções equivocadas que constituiriam, inclusive, obstáculos aos conceitos e ao pensamento científico vigente.

A mudança de status do senso comum pode ser percebida ao longo da história. No entanto, esta foi conquistada à medida que fomos nos integrando a novas atividades e que nossa relação com a natureza nos revelou dimensões outrora distantes e não incorporadas às atividades vigentes. Poincaré (1995) aponta para o desenvolvimento da astronomia como algo que tenha nos preparado à compreensão, e mesmo à percepção, dos "grandes números". Conceber valores como a distância entre o Sol e a Terra em quilômetros nos prepara para o futuro no qual lidamos com o infinitamente grande, mas também com o infinitamente pequeno. Algo que hoje pode ser ensinado na escola como o comprimento de onda da luz azul, ou o número de Avogadro, e de alguma forma ser compreensível a alunos na faixa etária de 15 a 17 anos, pode ter sido inconcebível em dado momento histórico ${ }^{30}$.

\footnotetext{
${ }^{30}$ Ainda que tal proposição possa ser encarada como anacrônica, o que destacamos nesse parágrafo é como o desenvolvimento da ciência desempenha, ao longo da história, um papel de força motriz na mudança de status do senso comum.
} 
Tentemos retroceder e imaginar o que pensaria um grego a quem fôssemos dizer que a luz vermelha vibra quatrocentos milhões de milhões de vezes por segundo. Sem dúvida alguma, uma tal asserção the parecia pura loucura, e ele jamais se rebaixaria ao ponto de verificá-la. Hoje, uma hipótese não nos parecerá mais absurda porque nos obriga a imaginar objetos muito maiores ou muito menores do que aqueles que nossos sentidos são capazes de nos mostrar, e não compreendemos mais esses escrúpulos que tolhiam nossos predecessores e os impediam de descobrir certas verdades simplesmente porque as temiam. Mas por quê? Porque vimos o céu crescer, e crescer incessantemente; porque sabemos que o Sol está a 150 milhões de quilômetros da Terra, e que as distâncias das estrelas mais próximas são centenas de milhares de vezes maiores ainda. Habituados a contemplar o infinitamente grande, tornamo-nos aptos a compreender o infinitamente pequeno. Graças a educação que recebeu, nossa imaginação assim como o olho da águia, que não é ofuscado pelo Sol pode olhar de frente a verdade. (POINCARÉ, 1995, p.106, grifos nossos]

A concepção de senso comum nos interessa na medida em que pensamos o uso de analogias em atividades didáticas, no nosso caso particular voltadas ao ensino de física quântica, e tentamos estabelecer relações entre um conhecimento que é de apropriação do estudante com um novo conhecimento. Se percebemos que na produção do conhecimento científico lançamos mão daquilo que consideramos "senso comum" para avançar no desenvolvimento do novo conhecimento e, sobretudo, se identificamos esse processo no desenvolvimento do que chamaremos de Física Moderna e Contemporânea (nesse caso as bases da teoria da relatividade restrita e geral, assim como da física quântica), podemos nos apropriar das questões histórico-epistemológicas presentes e, a partir dessa perspectiva, desenvolvermos instrumentos que nos auxiliem em nosso problema de pesquisa, o uso de analogias em aulas de física quântica.

Um exemplo da reformulação do "senso comum", que nos remete ao desenvolvimento de conceitos da física do século $X X$, é a experiência de pensamento dos gêmeos de Langevin. Esta parece buscar a nova compreensão do sentido físico dos conceitos de espaço e tempo relativísticos.

Vejamos, então, um relato resumido da experiência de pensamento proposta pelo físico francês Paul Langevin na Conferência de Solvay realizada em Bruxelas, em 1911: 
Um viajante do espaço se despede de seu irmão gêmeo e se afasta do planeta Terra, onde deixara seu irmão, com velocidade muito próxima da velocidade da luz. Este mantém comunicação com a Terra via troca de sinais eletromagnéticos. Supondo que a velocidade do viajante tenha se mantido no intervalo inferior a um vigésimo de milésimo da velocidade da luz, e que ele retorne a Terra ao final de dois anos de seu tempo de relógio (desconsiderando a inversão do movimento ao cabo do primeiro semestre, considerando que esta tenha sido muito rápida, resultado da interação com o campo gravitacional de uma estrela), é provável que ele se espante ao encontrar seu "velho" planeta envelhecido de dois séculos. Apresentamos a seguir a explicação detalhada descrita por Langevin para o presente fato e, sobretudo, a questão a respeito da troca do referencial para o irmão que em nosso planeta permaneceu, não gerar o efeito inverso, o que caracterizaria o "paradoxo dos gêmeos". Na verdade, ele responde por que o efeito de dilatação do tempo não é simétrico.

\begin{abstract}
Durante a viagem de ida, como eles se afastam um do outro, os sinais levariam muito tempo para chegar até eles: "Cada um deles verá o outro viver duzentas vezes mais lentamente do que normalmente ", e o viajante, durante o primeiro ano, só receberá os sinais dos dois primeiros dias terrestres. Além do mais, esses sinais serão deformados pelo efeito Doppler-Fizeau: o viajante os receberá com um comprimento de onda duzentas vezes mais longo que os emitidos pela Terra nesses dois dias. Na volta, ocorreria o inverso: os sinais recebidos pelo cosmonauta teriam um comprimento de onda duzentas vezes mais curto que os emitidos da Terra, e "cada um deles verá o outro viver uma vida particularmente acelerada (...) e o explorador, no ano que durará seu retorno, verá a Terra realizar os gestos de dois séculos". No total, o viajante terá visto "a Terra se afastar e se aproximar dele num espaço de tempo igual, do seu ponto de vista, a um ano, enquanto que a Terra (...) vê o viajante dela se distanciar num espaço de dois séculos e voltar em dois dias, isto é, em um tempo quarenta mil vezes mais curto". (A dissimetria entre os dois espaços de tempo, o da Terra e o do viajante, deve-se ao fato de que o viajante foi submetido a uma inversão de direção, provocada por um movimento acelerado, que passa a considerar um referencial privilegiado) (LANGEVIN, apud, PATY, 2003).
\end{abstract}

Essa descrição da experiência de pensamento de Langevin mostra que, a partir da teoria da relatividade restrita de Einstein, os conceitos de espaço e tempo não são meras abstrações matemáticas, antes, porém, estes conceitos têm 
aplicações e sentidos físicos do ponto de vista dos fenômenos. Na verdade, esses conceitos ganham aí nova significação. Como destaca Paty (ibidem): " Os novos conceitos de espaço e de tempo eram tão racionais e naturais quanto os antigos (e o eram ainda mais, pois se adaptavam melhor ao conjunto dos fenômenos físicos) e se conciliavam igualmente com aqueles do senso comum - um senso comum renovado."

A mudança de "status" do senso comum, concebendo o caráter "natural" aos conceitos de espaço e de tempo, pode nos auxiliar na tarefa de comunicar a um público não especialista a teoria da relatividade restrita. No que diz respeito à teoria da relatividade restrita e geral, destacamos um filme lançado em 2014 cujo titulo é "Interestelar"31. Não discutimos aqui as intenções dos produtores do referido filme, porém destacamos a possibilidade de tratar dos conceitos de espaço e de tempo, num filme voltado a um público "leigo" ${ }^{32}$, numa trama de ficção-científica que traz consequências semelhantes à experiência de pensamento proposta no início do século XX por Langevin.

Portanto, se temos a intenção de superar a contradição apontada por nós no início da tese, no sentido de representar os conceitos e/ou as entidades da física quântica as quais não possuem relação com nossa realidade sensível, julgamos fundamental buscar a construção do que aqui nomeamos como "mudança do status do senso comum". Destacamos, contudo, que tal mudança está presente ao longo do desenvolvimento histórico da ciência (talvez por isso Michel Paty tenha intitulado o seu trabalho de: "A ciência a as idas e vindas do senso comum").

Por exemplo, ao trabalharmos o conceito de inércia de Galileu com alunos da educação básica, buscamos contrapor, através de experimentos reais ou de pensamento, o senso comum a respeito da continuidade do movimento. Este é também um "movimento" de ampliação do conceito de inércia, dando-lhe um "status" que, assim como na experiência de Langevin, se adapte aos "novos"

\footnotetext{
${ }^{31}$ Buracos negros, buracos de minhocas, viagens no tempo e dilatação temporal são alguns fenômenos físicos que foram abordados no filme Interestelar. No entanto, não se coloca aqui se os temas foram abordados de forma que o público em geral compreendesse os "novos" conceitos de espaço e de tempo.

32 É verdade que as intenções e os motivos da realização de um filme são distintos daqueles cuja finalidade é o ensino. No entanto, nosso destaque ao referido filme se dá na medida em que vislumbramos a possibilidade de construção, em certo grau, de uma racionalidade apoiada no "senso comum".
} 
fenômenos apresentados. Entretanto, vale ressaltar que, de acordo com a perspectiva adotada na presente tese, os conceitos outrora construídos (quer sejam ordinários ou científicos, na conotação aqui adotada) não são esquecidos ou substituídos pelos "novos", mas antes mantêm-se na estrutura cognitiva do indivíduo no constante "movimento" de objetivação e generalização.

\subsubsection{O desafio da Física Quântica}

Nossa relação sensível encontra dupla barreira quando nos voltamos a sistemas quânticos, a saber, a relativa às dimensões e a relativa ao grande número de elementos. Afinal, nosso sentido visual alcança, com auxílio de microscópio, a ordem de $10^{-6} \mathrm{~m}$, enquanto nos sistemas quânticos trabalhamos na ordem $10^{-10} \mathrm{~m}$ (átomo) e $10^{-15} \mathrm{~m}$ (núcleo). Já a dificuldade associada a grandes quantidades é evidenciada no número de Avogadro, $\mathrm{N}=6,02 \times 10^{23}$, associado a "pequenas" quantidades, por exemplo, à molécula-grama ( $32 \mathrm{~g}$ no caso do Oxigênio).

Além destas, destacamos algumas dificuldades de ordem epistemológica na comunicação do conhecimento desenvolvido, ao se tratar do domínio da física quântica. Esse é um desafio que apresenta suas peculiaridades, afinal, como destaca Paty (2003):

A prática da divulgação científica é mais difícil e delicada no que diz respeito à física quântica, pois esta é uma área que escapa às representações habituais. Sua relação com o mundo familiar dos objetos e dos fenômenos clássicos é necessariamente remota e indireta".

A descrição do campo quântico em termos simples e segundo conceitos usuais, ou pelo menos clássicos, que corresponderiam ao senso comum, parece então impossível à primeira vista. Toda tentativa de utilização de analogias clássicas tenderia, neste caso, ao fracasso. Ela não esclareceria nem o senso comum, nem a razão (o julgamento racional). (PATY, 2003, p.16-17)

Como já destacamos anteriormente, ao pensarmos em ações didáticas que visam à compreensão de conceitos quânticos, devemos empenhar esforços particulares devido à peculiaridade de nosso objeto de conhecimento. Tais conceitos escapam de nossas representações habituais, afinal as relações até então 
constituídas são as dos fenômenos clássicos, e estes não possuem com aqueles relação familiar ou direta.

No entanto, na tentativa de superar a contradição de tornar inteligível um domínio do conhecimento que não apresenta relação direta com nossa realidade sensível, partimos da ideia de fazer um levantamento a priori de todas as possíveis barreiras conceituais, como as já apresentadas aqui (pequenas dimensões, grandes números, não-localidade etc). Qualquer aproximação, quer seja analógica ou não, que não leve em consideração as referidas barreiras, corre sérios riscos de não atingir os objetivos de fazer inteligíveis os conceitos da física quântica, ao contrário, pode reforçar ainda mais concepções equivocadas a respeito destes.

Ainda no mesmo artigo, Paty levanta um questionamento que vai ao encontro do interesse de nossa pesquisa. A saber, até que ponto os conceitos da Física Quântica também podem ser compreendidos, em princípio, pelo "homem comum"? Destacamos o texto abaixo no intuito de inferirmos algumas questões.

As grandezas quânticas são a função de estado e as variáveis dinâmicas (chamadas"observáveis", embora elas só o sejam indiretamente, através das quantidades clássicas).

A função de estado é, matematicamente, um "vetor de espaço de Hilbert", as variáveis dinâmicas são os "operadores" (de diferenciação, ou matrizes) agindo sobre a função de estado. As leis da física quântica são equações escritas com essas entidades, "equações de valores próprios", cujas soluções fornecem o espectro dos valores possíveis dessas grandezas, correspondendo às obtidas através de observação. A diferença entre a fase de descrição teórica e a de observação consiste no fato de que a segunda nos fornece separada e consecutivamente cada um dos estados possíveis $\left(\Psi_{1}, \Psi_{2}, \Psi_{3}, \ldots\right)$, enquanto a primeira indica globalmente o conjunto desses estados "superpostos" (trata-se do "princípio de superposição"). Com efeito, a mais geral função de estado é uma superposição linear de soluções possíveis $\left(\Psi=a_{1} \Psi_{1}+a_{2} \Psi_{2}+\right.$ $\left.\mathrm{a}_{3} \Psi_{3}+\cdots\right)$. Os estados observados na aparelhagem correspondem a cada um dos elementos da superposição $\left(\Psi_{\mathrm{i}}\right)$ afetado por uma probabilidade fornecida pelo seu módulo quadrado $\left(\mathrm{P}_{\mathrm{i}}=\left|\Psi_{\mathrm{i}}\right|^{2}\right)$. (PATY, 2003, p.18).

O não especialista, ao ler o fragmento acima, tem a impressão de se tratar realmente de algo incompreensível, ao menos para o seu "senso comum". É a partir dessa incompreensão inicial que propomos uma ampliação da racionalidade e uma reformulação do "senso comum". Baseamo-nos no que chamamos de percurso 
histórico "traçado" na dimensão epistemológica. a fim de nos apropriarmos de alguns constructos que apontem para a inteligibilidade dos conceitos quânticos.

Nosso apelo à compreensão dos referidos conceitos pelo "homem comum" se dá na medida emque a referida categoria, aqui adotada, inclui também os sujeitos aos quais dedicamos nossa reflexão, a saber, o conjunto de alunos da educação básica. Temos, portanto, o propósito de ampliar o repertório racional dos indivíduos na busca de um novo "status" de senso comum, "status" este que possibilite a comunicação inteligível dos conceitos, a priori sem relação direta com a realidade sensível, que são estes ligados à Física Quântica.

Nosso tempo histórico goza de certa vantagem por conhecermos 0 desenvolvimento da teoria quântica desde o início do século $X X$ até os nossos dias. A vantagem aqui levantada está relacionada ao nosso interesse de pesquisa, 0 ensino de física quântica voltado a alunos da educação básica, uma vez que o percurso histórico aqui sugerido visa ampliar o que chamamos de senso comum e garantir significados às representações ligadas ao referido domínio da física. Entretanto, ressaltamos que lançar mão da história da ciência deve ser mais que apresentar episódios da ciência como sequência de fatos que levaram de forma causal "simples" ao desenvolvimento da teoria quântica. Sobretudo, desejamos lançar mão desse percurso histórico a fim de estabelecer e negociar os significados dos "conceitos/entidades" que emergem dessa reflexão.

Diversos manuais didáticos partem do problema da radiação do corpo negro a fim de evidenciar que as teorias físicas então vigentes não davam conta de descrever o fenômeno observado. Estes parecem traçar uma linha cronológica de eventos que vão resultar na apresentação da quantização de Planck, no efeito fotoelétrico e na discussão da natureza da luz. Alguns livros didáticos chegam também a apresentar o princípio da Incerteza de Heisenberg.

Assim como em diversas propostas, presentes inclusive nos manuais de ensino, entendemos que recorrer a fatos históricos que evidenciam limitações de uma teoria física vigente à época ao tentar descrever um fenômeno reforça a ideia de uma ciência em construção, na qual deixamos de ser meros expectadores e passamos a ser agentes nessa construção. Segundo Matthews (1995), a utilização da história e filosofia da ciência em atividades de ensino pode representar um elemento facilitador para a formação de alunos reflexivos que tenham a 
compreensão de ciência como parte da construção humana e, portanto, um legado da humanidade.

Partimos, mais uma vez, do princípio de que o ensino deve promover desenvolvimento psíquico. Segundo Vygotsky (1991), "O ensino seria totalmente desnecessário se pudesse utilizar apenas o que já está maduro no desenvolvimento, se ele mesmo não fosse fonte de desenvolvimento e surgimento do novo" (ibid., 2001, p. 334). Para isso lançamos mão das interpretações da mecânica quântica, a partir das quais buscamos a construção da inteligibilidade dos conceitos ali envolvidos.

O conhecimento racional, teórico, do domínio quântico que escapa aos sentidos e ao senso comum é, portanto, possível e sua comunicação pelo ensino beneficia-se doravante de uma longa e rica experiência. Mas qual é, neste caso, o estatuto do senso comum? Seria tentador aqui estabelecer uma distinção radical entre uma comunicação dirigida ao público, que se tornaria praticamente impossível devido à incapacidade do senso comum de aceder a esse domínio abstrato, e uma outra, reservada aos especialistas, unicamente fundada sobre o "formalismo matemático" da teoria quântica e sobre o savoir-faire (ou know-how) experimental, o único capaz de recuperar o sentido físico.

Entretanto, pode-se considerar artificial uma tal solução, pois os especialistas da física quântica não são feitos de uma matéria diferente da do "homem da rua" que supostamente se interessaria pelos quanta. Ora, os físicos também experimentam a necessidade de compreender "intuitivamente" e de modo sintético o que eles abordam tecnicamente, através do formalismo matemático e das experiências realizadas. Nisso consiste toda a questão da "interpretação" da física quântica, principalmente da sua forma mais "simples", a mecânica quântica, com seu aparelho teórico abstrato e suas experiências, aparentemente paradoxais. (PATY, 2003, p.19)

Tomando como base tais considerações, buscamos elementos no percurso histórico da epistemologia da física do século $X X$ a fim de analisar as tentativas de tornar inteligíveis as "novas" questões tratadas no campo da física quântica.

Nosso problema de pesquisa se reforça ao tentar resolver a contradição acima descrita. Nossa contribuição inicial se dá no sentido de corroborar com a literatura especializada na área de ensino de física, que aponta como positiva e, sobretudo, necessária a inserção de tópicos da física do século XX, incluindo 
obviamente a física quântica, nos currículos da educação básica ${ }^{33}$. Os contrários a essa iniciativa, incluo majoritariamente os físicos e os professores universitários, geralmente alegam a falta do formalismo matemático, que não está acessível no nível educacional supracitado. Não é nosso objetivo, por ora, discutir a importância da abordagem tampouco o potencial motivador do referido tema. Antes, baseados na epistemologia da ciência, fundamentalmente no que propomos anteriormente, numa redefinição do senso comum e numa ampliação do conceito de racionalidade, pretendemos discutir a possibilidade da inteligibilidade dos conceitos e fenômenos da física quântica (significação de um fenômeno quântico) a um público não especialista.

Como destaca Paty (ibid), em função de sua natureza abstrata e sem relação direta com a realidade sensível, a compreensão da teoria quântica encontrou diversos problemas. Conceitos como posição $(x)$, velocidade $(v)$, momento linear $(p)$, a energia ( $E$ ) etc., que descrevem os sistemas físicos clássicos e aparecem nos enunciados das leis físicas (mecânica, gravitação, eletromagnetismo, termodinâmica, etc.), relacionando-as através de equações diferenciais, não podem ser assim descritos nos sistemas quânticos. Se por um lado as grandezas quânticas não são estas da física clássica, e portanto não podem ser assim representadas, por outro lado, mesmo que as grandezas quânticas sejam "grandezas abstratas" (função de estado e as variáveis dinâmicas, ou "observáveis"), é por meio de medidas via instrumentos clássicos que temos acesso aos objetos da física quântica (fótons, elétrons, radiações). É então que surge mais uma contradição: "Esses fenômenos chegam ao nosso conhecimento através de instrumentos clássicos, ao mesmo tempo escapando à descrição clássica."

Com todas as questões problemáticas apontadas na física do início do século $\mathrm{XX}$, ressaltamos que os físicos, desde o início do desenvolvimento da teoria quântica, manipulavam, sem muitos problemas, o formalismo matemático correspondente a essa teoria. No entanto, a fim de propor uma inteligibilidade às questões relacionadas à física quântica, iniciou-se 0 debate relativo às interpretações da Mecânica Quântica (MQ).

\footnotetext{
${ }_{33}$ Jones (1991); Aubrecht, (1999); Gil e Solbes, (1993); Fischler e Lichfeldt, (1992); Lawrence, (1996); Pospiech, (1999) e (2000); Veit et all, (1987); Stannard, (1990); Terrazan, (1992); Ostermann e Moreira, (2001); Greca (2001); Lobato e Greca (2005).
} 
Vemos em alguns trabalhos um esforço nesse sentido. Alguns exemplos são os dois volumes do livro "Conceitos de Física Quântica", de Osvaldo Pessoa Jr. (PESSOA, 2003), que lança mão das interpretações da Teoria Quântica (TQ) a fim de obter a inteligibilidade dos fenômenos a esta associados. $O$ referido trabalho chega a apontar a possibilidade de compreensão, até certo ponto, a um grupo de pessoas que não tenham familiaridade com a $M Q$, como alunos de Filosofia, Ensino de Ciências e História da Ciência, no entanto, todos em nível de pós-graduação. Seu livro foi concebido como resultado de uma década de cursos de fundamentos conceituais da física quântica ministrados nos Institutos de Física da Universidade de São Paulo e da Universidade Federal da Bahia.

Os livros supracitados têm como público alvo alunos que já tenham passado pela graduação, ainda que em áreas que não estejam diretamente ligadas à Física. Mesmo assim, trata-se de alunos com certo grau de maturidade que thes permite acompanhar, mesmo com certa dificuldade técnica, as discussões ali propostas. No primeiro volume, o autor recupera de forma simples e acessível conceitos da física clássica, como os conceitos de onda e de partícula, o que permite ao leitor perceber o que ele ali denomina de "A contradição entre Onda e Partícula" ${ }^{34}$. De fato, é preciso elucidar o problema "irreconciliável" entre os conceitos de onda e partícula, o que seria percebido de forma simples por sujeitos que compreendam as definições dos dois conceitos relatados. Contudo, o "homem comum" aceitaria sem nenhum espanto aparente a apresentação de entes físicos que se manifestam ora como onda, ora como partícula. Tal fato reforça a necessidade de se explicitar as contradições "aparentes" entre os dois conceitos. Identificamos, portanto, um movimento já na ampliação da racionalidade dos sujeitos ouvintes assim como na incorporação por estes de um novo "status" de senso comum (conforme a fórmula de Langevin: "O concreto é o abstrato tornado familiar pelo uso") ${ }^{35}$.

Apesar de reconhecermos as diferenças entre a referida obra e a presente tese, lançamos mão da abordagem do tema (Teoria Quântica) proposta por Pessoa Jr (2003), a fim de mostrar a possibilidade de tornar inteligíveis conceitos da Física

\footnotetext{
${ }^{34}$ Segundo Pessoa (2003), poderíamos começar um curso de Física Quântica destacando as diferenças entre esta e a Física Clássica, dentre as quais destacamos: a relação entre contínuo e discreto; o papel que a probabilidade desempenha num mundo essencialmente "indeterminista"; o Princípio da Incerteza; o princípio quântico da superposição; a questão da não-localidade; a dualidade onda-partícula, dentre outras questões. No entanto, o autor decide partir da dualidade onda-partícula.

${ }^{35}$ Descrição da fórmula de Langevin segundo Paty (2003).
} 
Quântica, sendo que esta pesquisa busca pensar no papel das analogias na comunicação e no ensino da Física Quântica. Entretanto, nossa perspectiva é de, antes, buscar certa ampliação da racionalidade dos alunos, mudando assim o "status" do senso comum entre eles partilhado, de forma a criar a possibilidade de fazer relações analógicas. Julgamos, portanto, fundamental a busca por essa ampliação, a fim de evitar associações "frágeis" entre a realidade sensível imediata e os fenômenos quânticos. É, portanto, nesse sentido que levantamos alguns elementos presentes na obra "Conceitos de Física Quântica - Volume 1".

A fim de que a contradição onda-partícula seja realmente percebida pelos estudantes como tal, busca-se, por meio de revisão, ou mesmo de apresentação, fundamentar os fenômenos importantes que serão usados nas discussões presentes na "nova" teoria. É fundamental perceber que, em determinados casos associados à mecânica clássica, os elementos do senso comum já estão presentes, pois, diversas vezes, os fenômenos que são apresentados constituem atividades semelhantes àquelas com as quais os estudantes, ao menos uma vez, já se depararam. Tal configuração e contexto da comunicação permitem a existência de um análogo que esteja ligado à sua experiência pregressa.

Mais uma vez trazemos à tona a discussão a respeito do conceito clássico de inércia. Nesse caso, o professor dispõe de um considerável repertório que permite o diálogo com os alunos, a fim de explorar o referido conceito a partir do senso comum associado ao fenômeno em questão. Situações como um trem que freia ao se aproximar de uma estação e a "impulsão" no sentido do movimento experimentada pelos passageiros no interior de um dos vagões, ou o número de um artista que puxa uma toalha de mesa sobre a qual é colocado um aparelho de jantar completo, e estes objetos permanecem "inertes", são exemplos de eventos aos quais os professores podem recorrer a fim de contrapor o senso comum ligado ao conceito de inércia segundo Galileu Galilei (séc. XVII).

Em contrapartida, em outros contextos e domínios da ciência, os elementos do senso comum não estão nem ao menos presentes no repertório de experiências conhecidas pelos estudantes $^{36}$. De fato, alguns domínios da física requerem, antes de mais nada, o primeiro contato com os elementos pertencentes aos fenômenos

\footnotetext{
${ }^{36}$ Vale destacar que, fundamentalmente no século XXI, com o acesso às informações via internet, é extremamente imprecisa a delimitação de fenômenos que já foram "vivenciados" pelos estudantes (Nosso caso, em particular, toma como amostra o conjunto de estudantes na faixa etária entre 15 e 18 anos). Ainda assim, julgamos pertinentes as observações aqui pontuadas.
} 
que serão então apresentados. Tal apresentação se constitui, a nosso ver, como construção de novos "status" do senso comum, e o seu uso assim o reforça.

Nesse sentido, a fim de constituir os fenômenos corpuscular e ondulatório como fenômenos irreconciliáveis, se faz necessária a referida construção. De forma clara, Pessoa Jr. (2003) apresenta os conceitos de onda e de partícula e, propositalmente, enfatiza a contradição lógica de admitir que algo seja ao mesmo tempo onda e partícula.

Para a Física Clássica, uma partícula pode ser imaginada como uma bolinha bem pequena que se locomove pelo espaço, e que em condições normais não se divide. Além dessa indivisibilidade, uma partícula clássica também se caracteriza por estar sempre em uma posição bem definida, e com uma velocidade precisa. Com o passar do tempo, uma partícula descreve uma trajetória bem definida, que pode ser concebida como uma curva no espaço.

Uma onda, por outro lado, é concebida pela Física Clássica como uma excitação que se propaga em um meio, como a superfície da água, e que tem a característica de se espalhar no espaço. O que se propaga com a onda é a energia, que se identifica com o movimento oscilatório das partículas do meio. Como esse movimento das partículas pode ser tão tênue quanto se queira, podemos dizer que as ondas não possuem a característica de serem indivisíveis, mas que são continuas, pelo menos em teoria. Além disso, as ondas circulares na superfície d'água claramente não descrevem uma "trajetória", do tipo definido para partículas. Elas são espalhadas no espaço, sem se localizarem em um ponto bem definido. Além de serem contínuas e espalhadas, as ondas exibem uma série de fenômenos típicos, como a interferência.

Dizer simplesmente que "uma coisa (sem partes) é (ao mesmo tempo) partícula e onda" é uma contradição lógica. Por isso implicaria que essa coisa é indivisível e divisível (contínua), que ela segue uma trajetória e não segue (é espalhada). Não podemos admitir uma contradição nos fundamentos de uma teoria física (apesar de este ponto ser passível de discussão). (PESSOA JR., 2003, p.2)

Após "deflagrar" a presente contradição lógica (ao menos no sentido clássico dos conceitos de onda e partícula), seu próximo passo consiste em apresentar resultados experimentais que parecem dar aos objetos quânticos (elétron, fóton, etc.) características ora de onda ora de partícula. No entanto, na mesma perspectiva da ampliação da racionalidade e na mudança do "status" do senso comum, é essencial que os estudantes em questão percebam, através de fenômenos físicos, características que definam, sem nenhuma dúvida, a que categoria pertence 0 objeto físico em questão. Por isso, o autor apresenta o conceito de superposição de 
ondas e o fenômeno de interferência, sem o conhecimento dos quais as discussões que se seguem tornar-se-iam sem sentido.

O encontro de pulsos que se propagam em uma corda clássica resulta numa configuração que depende das condições relativas entre os pulsos originais. $\mathrm{Na}$ verdade o pulso resultante dessa interação tem uma amplitude correspondente à soma das amplitudes dos pulsos originais. Este é o princípio da superposição concernente à física ondulatória clássica que poderia ser assim enunciado: quando várias ondas passam por um mesmo ponto, a amplitude resultante é a soma das amplitudes componentes. Sendo duas ondas periódicas com o mesmo comprimento de onda $\lambda$, cuja direção e sentido de propagação sejam coincidentes, a superposição pode ser construtiva se essas encontram-se em concordância de fase, ou destrutiva se houver um deslocamento de $\lambda / 2$ entre elas.

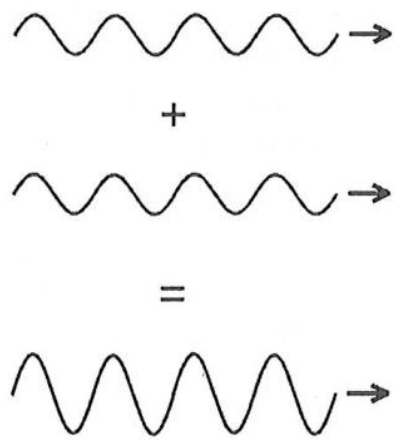

(a)

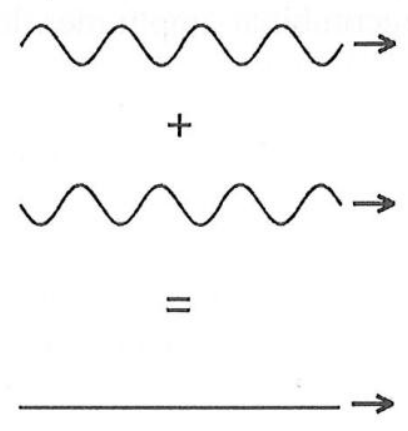

(b)

Figura 4.2 - Superposição de ondas: (a) construtiva (ondas em fase); (b) destrutiva (ondas fora de fase). ( PESSOA, 2006, p.7)

Uma vez compreendido o fenômeno de superposição de ondas, o fenômeno de interferência torna-se em seguida também compreensível. Para isso, é apresentado um esquema do experimento de dupla fenda realizado pelo físico inglês Thomas Young no início do século XIX. No entanto, foi necessário aguardar o início do século XX para que Geoffrey Taylor realizasse o referido experimento com fontes de luz extremamente tênues, a fim de que chegasse apenas um fóton a cada instante. 

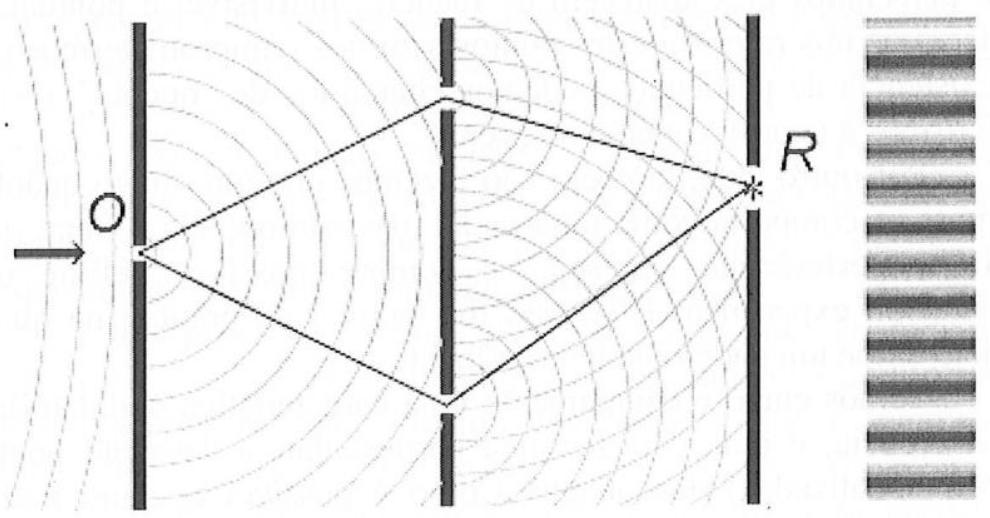

Figura 4.3 - Experimento de dupla fenda para a luz. (PESSOA, 2006, p.3)

O padrão de claros e escuros obtidos no terceiro anteparo, chamado de franjas de interferência, ocorre devido às múltiplas superposições entre as ondas "geradas" através das duas fendas. Contudo, destaca-se que tal padrão de interferência ocorre mesmo na experiência de 1909 realizada por Taylor com uma fonte de luz tênue, a partir da qual é necessário esperar determinado intervalo de tempo, a fim de que o padrão de interferência se forme. É, no entanto, a partir da década de 1950 que o experimento é também realizado com elétrons, e, semelhantemente, o que ocorre com fótons unitários ocorre também com elétrons, ou seja, ao acompanharmos a formação do padrão de interferência em telas fosforescentes, percebemos tal padrão sendo formado ponto a ponto. Esta, contudo, é ainda caracterizada como versão fraca da dualidade onda-partícula. "Para qualquer objeto microscópico, pode-se realizar um experimento tipicamente ondulatório (como um de interferência), mas a detecção sempre se dá através de uma troca pontual de uma pacote mínimo de energia". (PESSOA JR., 2003, p.3)
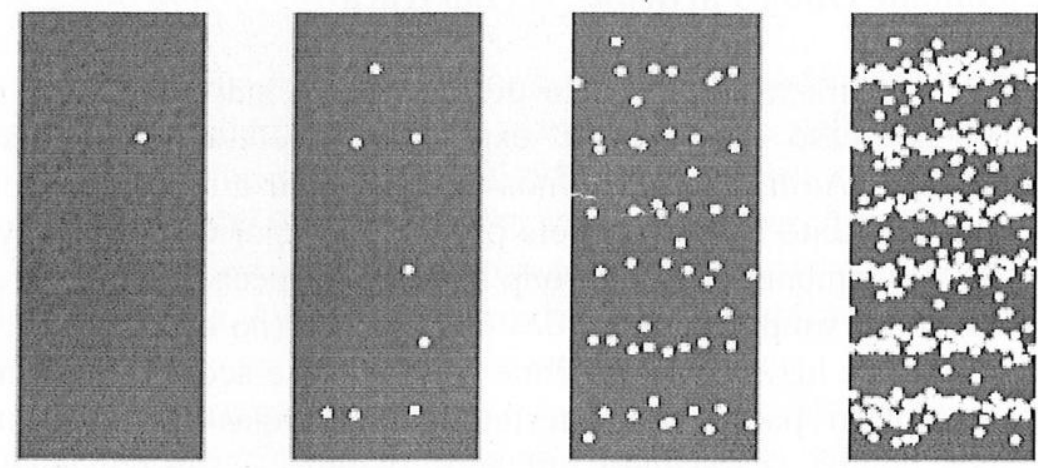

Figura 4.4 - Formação paulatina do padrão de interferência.(PESSOA, 2006, p.4) 
Destacamos o percurso do autor na construção da inteligibilidade dos conceitos associados à Física Quântica. Pessoa Jr. (2003) decide desde o início o caminho de apresentação de tais conceitos. Segundo o autor, a dualidade ondapartícula está presente desde os primórdios do desenvolvimento da Teoria Quântica. No entanto, como destacamos anteriormente, a dualidade onda-partícula pode não apresentar nenhum "desconforto" para alunos que não tenham tanta familiaridade com tais conceitos. Portanto, a ideia de propor inicialmente a incompatibilidade entre os dois conceitos se apresenta como essencial. Vale, contudo, destacar que a simples apresentação das características de fenômenos ondulatórios e corpusculares pode ainda ser insuficiente para que os ouvintes percebam, da forma que desejamos, tamanho problema que a física enfrentara ao se deparar com experimentos com "partículas" que se manifestavam em determinadas condições como ondas (difração de elétrons), assim como experimentos com a luz que eram explicados como se esta fosse partícula (efeito fotoelétrico). Nesse sentido, o autor propõe causar um "espanto" lógico a partir do qual os alunos tendem a rejeitar uma conciliação imediata entre os dois conceitos.

É portanto a partir e baseado nesse percurso que apontamos a necessidade de criar uma nova estrutura de ordem cognitiva que permita "avançar" na busca por um novo "status" de senso comum. Sobretudo, reforçamos o que indicamos como a possibilidade de tornar inteligível os conceitos da Física Quântica.

Uma vez que alguns fenômenos ondulatórios começam a fazer sentido, através do uso, para os alunos, Pessoa Jr.(ibid) agrega elementos que, por um lado, avançam na complexidade dos fenômenos, e assim se aproxima das discussões que se seguem, por outro lado, reforça as "novas percepções" presentes no novo "status" do senso comum que ainda se encontra em fase de consolidação.

Um experimento simples, no qual um feixe de laser de intensidade $I_{0}$ incide num espelho semi-refletor $S$ e o divide em dois feixes de mesma intensidade $I^{\prime}$, onde $I^{\prime}=I_{0} / 2$, é a seguir apresentado: 


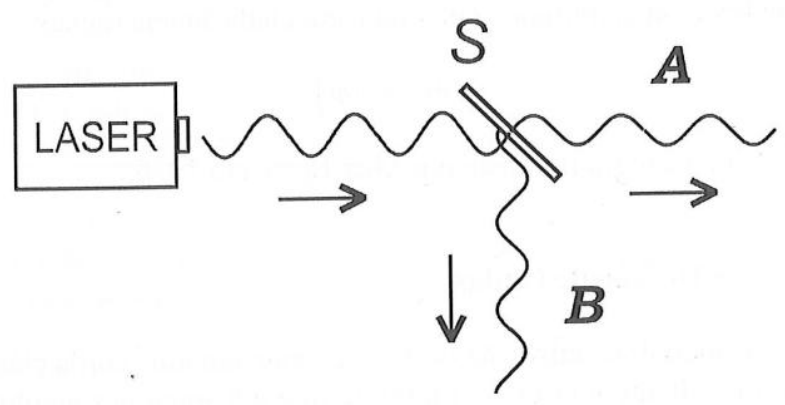

Figura 4.5 - Feixe emitido por uma fonte laser é dividido em duas partes A e B de igual amplitude.( PESSOA, 2006, p.8)

Vale destacar também a necessidade de se explicitar que, mesmo para ondas clássicas, a relação entre a intensidade / de uma onda (energia por unidade de tempo e de área) é proporcional ao quadrado da amplitude $\psi$.

$$
I \propto \psi^{2}
$$

Sendo assim, não é difícil mostrar que: como $I^{\prime}=I_{0} / 2$, sendo $\psi^{\prime}$ a amplitude final de cada componente, $\psi^{\prime}=\psi_{0} / \sqrt{2}$ e não a metade de $\psi_{0}$ (amplitude da onda original).

Mais uma vez, então, somos confrontados com uma aparente contradição, afinal, se voltarmos a combinar os dois feixes divididos pelo espelho semirrefletor com superposição construtiva, teríamos: $\psi_{0} / \sqrt{2}+\psi_{0} / \sqrt{2}=\sqrt{2} \cdot \psi_{0}$. Tal resultado é "absurdo", pois, ao calcularmos a intensidade do feixe resultante, encontraríamos 2. $I_{0}$, ou seja, uma intensidade maior que a inicial.

Percebamos, portanto, que a construção do novo "status" do senso comum se apresenta no sentido de "fazer surgir" contradições que antes não seriam percebidas como tais, se baseadas em níveis mais ordinários do pensamento. No entanto, as referidas contradições não são criadas pelo simples "capricho" de apresentar a ciência como algo espetacular, antes o presente esforço se dá a fim que os estudantes, não habituados com as questões do domínio da ciência em questão, se 
apropriem do conhecimento ora apresentado, e percebam as contradições conceituais inerentes à análise dos fenômenos físicos envolvidos.

A fim de resolver mais essa contradição, propõe-se o experimento de MachZehnder, a partir do qual os alunos podem perceber que a superposição proposta anteriormente não é possível. Inicialmente, trata-se de um experimento ainda no nível clássico, no qual se incide apenas um "trem de onda". O Interferômetro é composto por uma fonte de luz (LASER), dois espelhos semirrefletores $\left(S_{1}\right.$ e $\left.S_{2}\right)$, dois espelhos planos $\left(E_{1}\right.$ e $E_{2}$ ), e dois detectores. $O$ esquema abaixo (fig. 3.4) ilustra de forma simplificada o arranjo experimental. Fica, então, simples para o aluno perceber que são necessárias algumas "manobras" a fim de recombinarmos as ondas que foram outrora divididas pelo espelho semirrefletor $\mathrm{S}_{1}$.

Antes de seguir na análise do que ocorre nos detectores do arranjo experimental, é necessário discutir o que ocorre com o "trem de onda" ao passar através dos espelhos semirrefletores. Na verdade, considera-se aqui que, a cada passagem por um espelho semirrefletor, a parte que é refletida sofre um avanço de $\lambda / 4$ em relação à parte que o atravessa ${ }^{37}$.

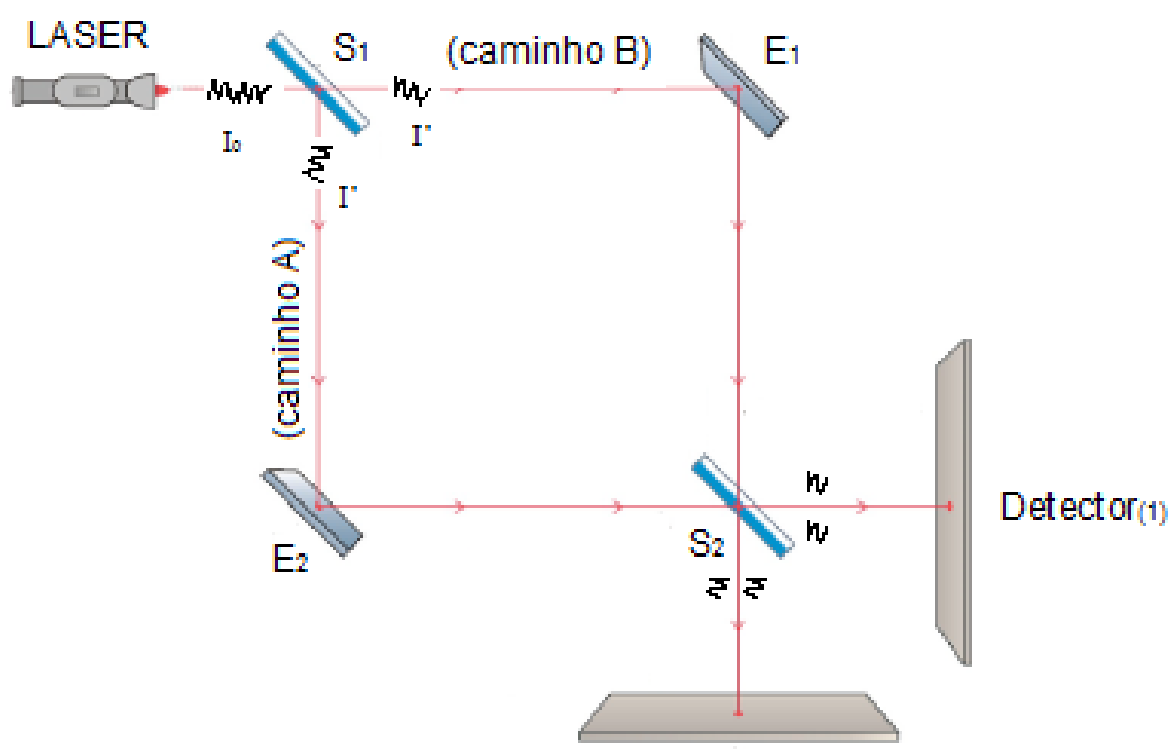

Detector $(2)$

Figura 4.6 - Esquema do interferômetro de Mach-Zehnder.

\footnotetext{
${ }^{37} \mathrm{Na}$ verdade o que ocorre é um retardo da parte que atravessa o espelho semirrefletor. No entanto, não há diferença de considerar o avanço da parte refletida ou do retardo da parte refratada. $O$ retardo de $N / 4$ é válido para espelhos semirrefletores que não absorvem a luz e que são simétricos (ZEILINGER, 1981, p. 882-3).
} 
Baseados nas presentes considerações, cabe agora seguir cada componente da onda que segue respectivamente os caminhos $A$ e $B$, recombiná-los e em seguida discutir o que ocorre em cada detector.

É possível que os alunos, ainda influenciados pelo senso comum "ordinário", sejam levados a inferir que cada detector medirá $50 \%$ do feixe (inclusive, o esquema do interferômetro parece induzir a essa conclusão precipitada). É então a partir da análise de cada fração do feixe que eles podem chegar à conclusão, contra-intuitiva, de que, se as distâncias percorridas pelas "frações" do feixe inicial são iguais e sob algumas condições particulares do arranjo experimental, 100\% do feixe inicial incide no anteparo 1 e $0 \%$ no anteparo 2 .

Tal conclusão pode em princípio parecer ilógica ao "homem comum". Entretanto, apontamos que um novo "status" do senso comum encontra-se em fase de desenvolvimento, de modo que os sujeitos envolvidos no processo se apropriam cada vez mais dos signos e dos significados dos conceitos ali envolvidos. Não será agora complicado para o aluno concluir que é necessário verificar que tipo de superposição ocorre a cada par de $1 / 4$ do feixe inicial que "se aproxima" dos anteparos. Uma vez que o faça, ele percebe que, para o par que se aproxima do detector (anteparo) 1, a superposição é construtiva, enquanto que, para o par que se aproxima do detector (anteparo) 2, a superposição é destrutiva. Isso justifica 100\% do feixe inicial incidir no anteparo 1 e $0 \%$ no anteparo 2 e, ao contrário de ser "estranho", torna-se um resultado esperado.

Toda discussão apresentada até o momento está ainda centrada em fenômenos clássicos. Mesmo assim, reforçamos a perspectiva aqui adotada de se criarem novas estruturas do pensamento, a fim de que estas sirvam como referência aos conceitos da Física Quântica que a priori não se relacionam diretemente com nossa realidade.

Apesar de a dualidade onda-partícula ter surgido anteriormente em nossas considerações, em concordância com Pessoa Jr. (2003), esta foi, no entanto, apresentada em sua versão "fraca". O que se segue, portanto, é a apresentação do experimento de Mach-Zehnder para fótons únicos, a partir do qual se pretende estabelecer o que o autor denomina de versão "forte" da dualidade onda-partícula. 
Propõe-se, então, um arranjo experimental a partir do qual seja possível a preparação do estado monofotônico. O experimento que foi realizado pela primeira vez na Île de France, em Orsay, permite a análise de um fóton apenas. Ou seja, ao invés de um "trem de ondas", analisa-se um fóton num arranjo experimental semelhante ao anterior. Os resultados, contudo, são os mesmos obtidos no caso do interferômetro clássico, ou seja, o fóton sempre é detectado em $D_{1}$ e jamais em $D_{2}$.

O nível de complexidade é cada vez maior, e as contradições só podem ser percebidas, tais como ocorreram no processo histórico do desenvolvimento da Mecânica Quântica, se os sujeitos envolvidos no processo de comunicação aqui proposto dipuserem de uma estrutura de pensamento adequada. Não se trata portanto de dar apenas aos estudantes "ferramentas" teóricas e matemáticas que sejam por eles utilizadas como pré-requisitos para compreensão de uma teoria. Não se nega, entretanto, a importância dessas "ferramentas", sobretudo, soma-se a elas a necessidade de se pensar em formas de pensar que favoreçam a compreensão dos conceitos que serão apresentados aos estudantes. A proposta em questão, apesar do seu caráter geral, é feita no contexto da presente tese, na qual buscamos compreender o papel das analogias nas atividades didáticas planejadas por professores voltadas às aulas de física quântica no ensino médio. Vale destacar que buscamos, desde o início, colaborar no sentido de resolver as contradições existentes nas ações de representação dos conceitos quânticos. Ainda de acordo com a perspectiva aqui adotada, lançamos mão de determinadas experiências realizadas no desenvolvimento da Teoria Quântica que buscam certa inteligibilidade dos fenômenos. O que realmente nos interessa é a possibilidade de, por meio de analogias, aceder aos conceitos e às "entidades" desse domínio da Física.

Voltemos então ao interferômetro e analisemos as questões que surgem ao utilizarmos um fóton por vez. 


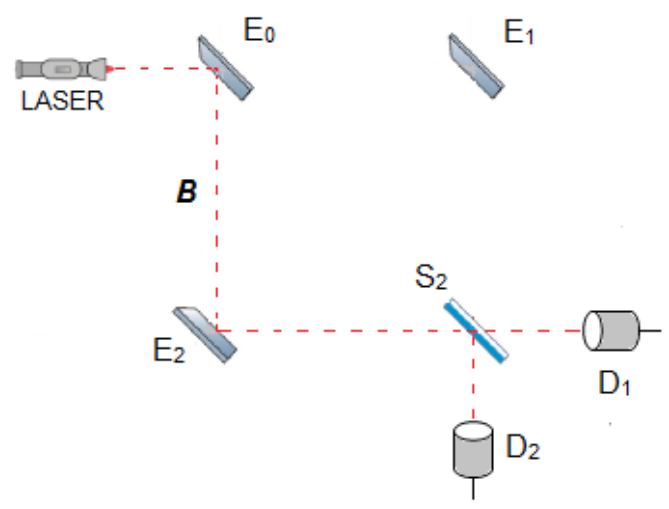

(a)

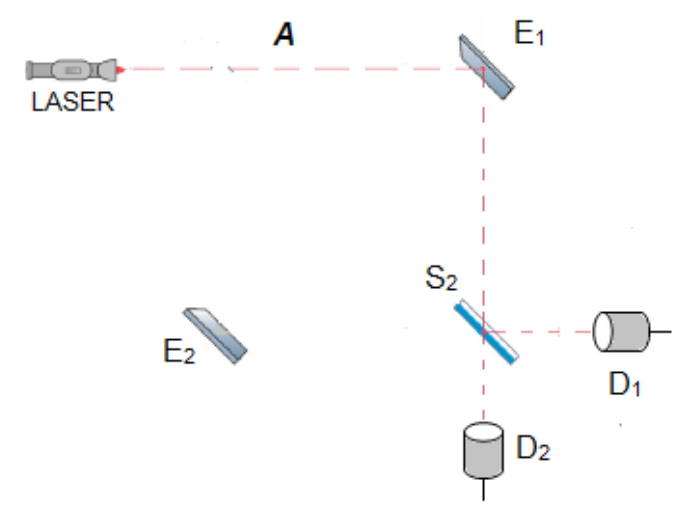

(b)

Figura 4.7 - Versões do interferômetro de Mach-Zehnder nos quais seria possível determinar a trajetória do fóton emitido pela fonte LASER: (a) o espelho semirrefletor $S_{1}$ é substituído pelo espelho de reflexão total $\mathrm{E}_{0}$; (b) o espelho semirrefletor $\mathrm{S}_{1}$ é removido.

A fim de explicitar o que aqui chamamos de versão "forte" da dualidade ondapartícula, vamos explorar o "caráter corpuscular" do fóton. Podemos imaginar que, para o esquema do interferômetro representado acima, não é difícil inferir a trajetória do fóton até ser detectada por um dos detectores aqui representados. No entanto, ao tentarmos fazer isso nos deparamos com algo mais uma vez contra-intuitivo, a saber, a falsa afirmação de que o fóton está em $\boldsymbol{A}$ ou em $\boldsymbol{B}$ ! Isso pode ser constatado através da seguinte suposição:

Vamos supor que o fóton se encontra em A e não em B. Isso pode ser realizado experimentalmente retirando-se o espelho semi-refletor $\mathrm{S}_{1}$ de seu lugar (fig. 3.5b) Nesse caso, o fóton incide em $\mathrm{S}_{2}$, e pode ser detectado ou em $D_{1}\left(50 \%\right.$ de probabilidade) ou em $D_{2}(50 \%)$, não ocorrendo nenhuma interferência de componentes. Se supusermos que o fóton inicialmente rumou por $B$, e não por $A$ (realizado pela substituição de $S_{1}$ por um espelho de reflexão total, fig. 3.5b), também teríamos $50 \%$ de detectá-lo em $\mathrm{D}_{2}$.

Agora, se o fóton estivesse em $\mathrm{A}$ ou em $\mathrm{B}$, continuaríamos a ter uma probabilidade de $50 \%$ de detectar o fóton em $D_{2}$. Isso segue a própria definição do conectivo lógico "ou": se em A é $50 \%$ e em B é $50 \%$, então em "A ou em B" tem que ser $50 \%$. No entanto vimos (...) a probabilidade de o fóton atingir $D_{2}$ não é $50 \%$, é $0 \%$ ! Logo é falsa a afirmação de que o fóton está em A ou em B! (PESSOA JR., 2003, p.12)

Vale mais uma vez destacar que a presente tese não tem como objetivo primeiro o de propor uma sequência didática para o referido tema. Antes, porém, lançamos mão, como exemplo, da abordagem apresentada por Pessoa Jr., uma vez que o autor tenta estabelecer comunicação dos conceitos quânticos a um público de 
não especialistas. Ressaltamos que nosso foco se dá na possibilidade de, a partir de tal abordagem (bem conduzida, ao nosso ver), tornar inteligíveis os fenômenos quânticos que fogem às representações diretas e mesmo se apresenta de forma "estranha" aos conceitos clássicos construídos e utilizados pela ciência até o início do século $X X$.

A busca por essa inteligibilidade nos parece razoável ao espírito humano, uma vez que, como destaca Paty (2003), tal "ambição" pela inteligibilidade é comum tanto ao especialista quanto ao não especialista. Vislumbramos, portanto, nas interpretações da Mecânica Quântica, movimentos de sujeitos que se propõem a enxergar certa "realidade" que está por trás dos fenômenos quânticos ou mesmo ressaltar a relação entre o "observador" e o "observado" . Tais questões, apesar de presentes em alguns domínio da Física Clássica, adquirem um novo sentido no domínio quântico e podem contribuir com reflexões a respeito da maneira pela qual o sujeito se vê no mundo e através dela ${ }^{38}$.

Tendo como base as considerações acima, julgamos pertinentes tomar os resultados do interferômetro de Mach-Zehnder, na montagem monofotônica, e inserir algumas interpretações dadas ao presente fenômeno.

(1) Interpretação Ondulatória. Talvez o fóton passa a se dividir simetricamente em dois "meio-fótons" no primeiro espelho semirefletor $S_{1}$. Em outras palavras, teríamos um pacote de onda que se dividiria em duas partes em $\mathrm{S}_{1}$, e estes se recombinariam em $\mathrm{S}_{2}$, conforme prevê a Física Ondulatória Clássica. O problema seria explicar por que em outros experimentos nunca detectamos meio-fótons.

(2) Interpretação Corpuscular. Conforme vimos acima, não dá pra supor que o fóton segue um dos caminhos e nada vai pelo outro. Qualquer visão corpuscular tem extrema dificuldade em explicar fenômenos ondulatórios. Uma saída possível, porém, seria argumentar que a lógica ao nível quântico é do tipo "nãoclássica". Se o conectivo "ou" fosse definido de maneira diferente, o raciocínio poderia ser invalidado.

(3) Interpretação Dualista Realista. Talvez o objeto quântico se divida em duas partes: o fóton e a sua onda associada. Assim mesmo, o fóton de fato seguiria uma trajetória, por $A$ ou por $B$, mas simultaneamente sua onda associada se dividiria em duas partes iguais, uma rumando por A e outra por B. A partícula seria um

\footnotetext{
${ }^{38}$ Tal discussão aparece nas considerações finais da presente tese no intuito de contribuir com trabalhos que apontam a importância da inserção de tópicos da Física do século XX nos currículos da educação básica.
} 
"surfista" que só pode navegar onde há ondas. Como as ondas se cancelam próximas ao detector $D_{2}$, o fóton é obrigado a surfar para $\mathrm{D}_{1}$.

(4) Interpretação da Complementaridade. Um fenômeno pode ser ondulatório ou corpuscular, nunca os dois ao mesmo tempo. $\mathrm{O}$ experimento examinado é um fenômeno ondulatório, e portanto não tem sentido perguntar onde está o fóton. (IBID, p.13)

A fim de mostrar que, dependendo do arranjo experimental, o fenômeno pode ser considerado como corpuscular ou ondulatório, esquematizamos abaixo 0 experimento de anticorrelação (fig.3.6a), assim como o interferômetro de MachZehnder com a ausência do espelho semirrefletor $S_{2}$.

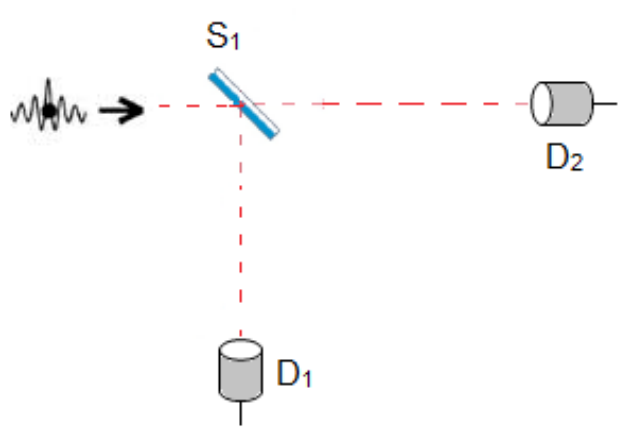

(a)

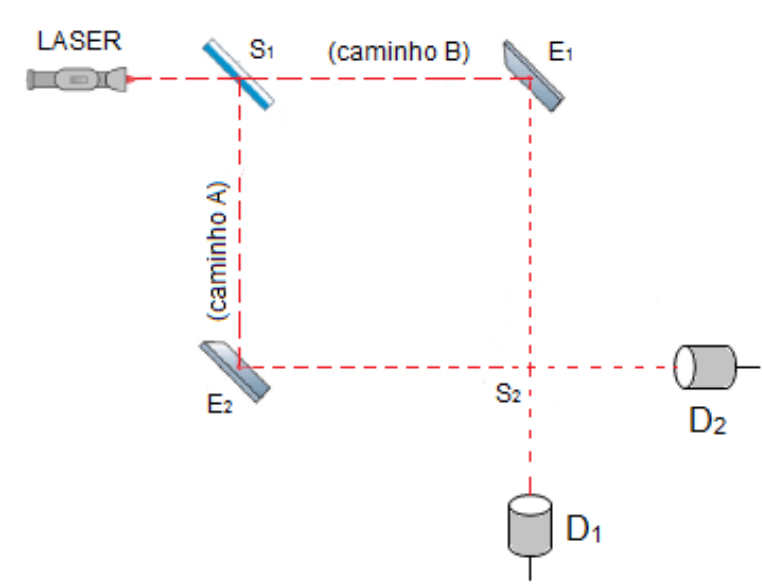

(b)

Figura 4.8 - Esquemas para o "fenômeno ondulatório": (a) experimento de correlação; (b) fenômeno corpuscular obtido a partir do interferômetro de MachZehnder.

Diferentemente do arranjo experimental representado na figura 4.4, o novo arranjo (assim como no experimento de anticorrelação) nos permite inferir com certeza a trajetória seguida pelo fóton após sua deteção em $D_{1}$ ou em $D_{2}$. É então a partir de tal possibilidade que aparece a versão "forte" da dualidade onda-partícula. Como destaca Pessoa Jr. (2003), uma vez realizado um experimento, é notável que as observações e medições revelem características de um fenômeno corpuscular ou 
de um fenômeno ondulatório, nunca os dois ao mesmo tempo. De acordo com o autor, poderíamos assim enunciar a versão "forte" da dualidade onda-partícula:

Um sistema quântico ou exibe aspectos corpusculares(seguindo trajetórias bem definidas), ou aspectos ondulatórios (como a formação de um padrão de interferência), dependendo do arranjo experimental, mas nunca ambos ao mesmo tempo.

Apesar de este enunciado não expressar as palavras de Niels Bohr, remete bem à interpretação da complementaridade assumida pelo físico Dinamarquês. Esta também é conhecida como a Interpretação de Copenhague. Para Bohr, os dois tipos de manifestações presentes nos experimentos realizados com objetos quânticos são excludentes e demonstram uma limitação fundamental de nossa linguagem na tentativa de representar o mundo. Segundo ele, nossa linguagem é adequada para representar os objetos e as relações do nosso mundo macroscópico, porém não conseguimos representar o mundo quântico de forma unitária, necessitamos de descrições que sejam complementares.

Para 0 arranjo experimental no qual o fóton se manifesta de forma corpuscular, é possível também analisá-lo de acordo com cada uma das interpretações aqui apresentadas. É bem verdade que, para certos arranjos, algumas interpretações parecem inferir propriedades e entidades a fim de dar conta de explicar o fenômeno em questão (como as "ondas vazias" e as "variáveis ocultas), mesmo assim, tais inferências não trazem nenhuma consequência observacional indesejável.

A partir das discussões levantadas até o momento, a obra apresenta os conceitos de superposição dos estados quânticos, discutindo assim as interpretações desses estados. Na sequência o autor sugere uma abordagem intuitiva do espaço de Hilbert e apresenta a noção de observáveis. O Princípio da Incerteza e o problema da medição também são tópicos abordados pelo livro. O autor lança mão do experimento de Stern- Gerlach a fim de discutir outras questões relacionadas à Mecânica Quântica, sempre recorrendo a algumas de suas 
interpretações. O texto avança tanto quanto na abordagem dos fenômenos quânticos, mas de forma "inevitável" também em complexidade. Apesar de objetivar a comunicação dos conceitos quânticos a não especialistas, o autor lança mão da linguagem matemática pouco familiar a sujeitos com formação que não seja em ciências exatas ${ }^{39}$.

Lançamos mão, de forma simplificada, da abordagem dos conceitos de Física Quântica proposta por Pessoa Jr. (2003), uma vez que identificamos na obra citada objetivos que se aproximavam do nosso, a saber, a possibilidade de tornar inteligíveis tais conceitos ao "homem comum". Apesar de vislumbrarmos certa potencialidade na forma com a qual os conceitos quânticos são ali apresentados, e de fato com algumas adaptações necessárias por se tratar de contextos distintos (cursos ministrados a alunos de pós-graduação e aulas para alunos da educação básica), reforçamos nossa perspectiva, que não busca aqui apresentar uma proposta didática apara o ensino de física quântica, antes, porém, a análise aqui proposta busca entender a referida abordagem como uma possibilidade de se desenvolver um novo "status" do senso comum, baseado no qual podemos comunicar os conceitos desse domínio da física.

No entanto, vale ressaltar que a criação de um novo "status" do senso comum não ocorre necessariamente antes da comunicação dos conceitos que são pretendidos, tal processo pode ocorrer simultaneamente. Nesse sentido, nossa perspectiva se diferencia daquelas que apontam para necessidade de se pensar em elementos a priori que se comportam como pré-requisitos ou base teórica, sobre a qual o novo conhecimento se apoia.

\footnotetext{
${ }^{39}$ Em nossa análise lançar mão da «linguagem » matemática como: auto-estados; auto valores; operadores auto-adjuntos; Hamiltonianos; produtos tensoriais, se dá no sentido de não perder o "rigor" do formalismo e assim abranger os detalhes técnicos/conceituais, de forma a permitir a um leitor que possui tais "ferramentas" uma leitura mais completa. A leitura descontextualizada do livro pode levar a interpretações equivocadas assim como à total incompreensão. No entanto, como exaluno da disciplina Fundamentos da Mecânica Quântica (2012-1) do programa de pós-graduação Interunidades em Ensino de Ciências, minhas impressões enquanto tal e minha análise a posteriori sugerem que, com as conduções do professor e a partir das questões ali levantadas, é possível promover reflexões a respeito da realidade física, da observação do mundo, dentre outras, pautados nos paradigmas da Mecânica Quântica.
} 


\subsubsection{Analogia e os Quanta de luz}

Como apresentamos no capítulo anterior, a perspectiva adotada na presente tese busca entender o papel das analogias na formação dos conceitos. Entendemos, portanto, que as analogias estão presentes na formação dos conceitos ordinários assim como na formação de conceitos mais complexos. As analogias desempenham um papel fundamental na relação intrapessoal do sujeito e também nas relações interpessoais, sendo a primeira involuntária e constante. Já a ação das analogias no segundo nível hierárquico, no qual se enquadram as atividades didáticas, ocorre de forma planejada e volitiva. É então a partir dessa perspectiva que propomos a possibilidade de criar, junto aos sujeitos envolvidos no processo de comunicação, o que é apontado por Paty (2003) como novos "status" para o senso comum. Vale lembrar que entendemos as analogias como elementos fundamentais no processo do pensamento humano, e que estas estabelecem relações profundas com a estrutura cognitiva, mais especificamente com o processo de categorização, na busca por novas estruturas de pensamento.

A fim de reforçar a perspectiva adotada na presente tese, retomamos (agora de forma mais detalhada) uma das analogias apontadas no capítulo anterior. Tal analogia (o corpo negro, análogo a um gás perfeito) está ligada a conceitos fundamentais da Física Quântica. Numa perspectiva do uso de analogias na comunicação de conceitos da Física Quântica, apresentamos a analogia proposta por Hofstadter e Sander (2013) para elucidar o pensamento analógico de Einstein.

No final do século XIX, um grande problema confrontava os resultados experimentais do espectro do "corpo negro" com as previsões das teorias físicas vigentes nessa época. A teoria ondulatória da luz ganhara há pouco sua sólida estrutura teórica por meio das equações de Maxwell, desenvolvidas e agrupadas como tal na segunda metade do século XIX. Na verdade, a luz pertence a um conjunto de radiações eletromagnéticas cuja evolução temporal pode ser descrita pelas quatro equações propostas pelo físico escocês. A teoria das ondas eletromagnéticas correspondia aos resultados experimentais de Thomas Young, da Inglaterra, assim como aos de Augustin Fresnel, da França, e seriam de forma brilhante confirmada em 1887 por Heinrich Hertz, na Alemanha. No entanto, restava 
misteriosa a questão do espectro do "corpo negro" em cujo âmago estão as ondas eletromagnéticas.

Antes de entrar nas reflexões e no pensamento analógico de Einstein, recorremos à analogia proposta pelos autores Hofstadter e Sander (ibid). Como na idealização do "corpo negro", que pode ser considerado como uma cavidade oca cujas paredes são mantidas a determinada temperatura, no interior da qual ondas eletromagnéticas refletem e se cruzam, como no interior de uma piscina com água que fora perturbada em função da queda de um objeto em seu interior. Segundo os autores, esta analogia entre a piscina e o "corpo negro" é esclarecedora na medida em que podemos analisar o que ocorre quando jogamos objetos dentro da piscina ${ }^{40}$. Diferentes objetos, de diferentes massas geram na piscina ondas com diferentes amplitudes e diferentes comprimentos de onda. As ondas geradas são em seguida refletidas nas paredes da piscina. Uma vez proposta a situação análoga, levantamos algumas questões que induzem e reforçam a semelhança entre as duas situações aqui descritas: "Qual será o comprimento de onda predominante em função da massa do objeto lançado?" Dada a massa de um objeto e um certo comprimento de onda, em que proporção este comprimento de onda contribui com a energia contida nas oscilações na superfície da água?" Uma vez levantadas tais questões, não é difícil imaginar que, a cada objeto lançado, há certo comprimento de onda que prevalece e que os comprimentos de ondas mais curtos e os mais longos são mais raramente suscitados pela queda do objeto. É possível então, a partir desses dados, representar graficamente algo que poderíamos denominar como o "espectro de ondas na superfície da piscina".

Como destacamos no capítulo 1, toda atividade baseada no uso de analogias com fins didáticos deve ser planejada a fim de que as semelhanças e as diferenças entre o análogo e o alvo sejam conhecidas pelo agente comunicador da atividade. Nesse sentido é importante destacar que a semelhança entre os dois fenômenos parece assim evidente, na medida em que propomos também para o fenômeno de objetos lançados na piscina um gráfico de distribuição de comprimentos de ondas geradas em sua superfície. Por outro lado, vale destacar a diferença relacionada aos meios de propagação das ondas nos dois contextos experimentais. Ao contrário do

\footnotetext{
${ }^{40}$ A fim de simplificar a analogia proposta, consideramos que todos os objetos não sejam lançados mas antes sejam abandonados de uma mesma altura (ainda que utilizemos os verbo lançar, jogar ou atirar).
} 
que ocorre na piscina, que conta com um meio físico (a água), no caso do "corpo negro", as ondas são entidades sem matéria, são campos elétricos e magnéticos que oscilam no espaço tempo, que se propagam numa direção ortogonal a estes, e que têm a capacidade de transferir energia a partículas portadoras de carga elétrica. $\mathrm{Na}$ analogia proposta, a temperatura corresponde à massa do objeto lançado na piscina e que provoca ondas em sua superfície. No caso do "corpo negro", quanto maior é a temperatura, maior é também a energia contida na cavidade, mais curto é o comprimento de onda dominante. No caso da piscina, quanto maior a massa, maior também será a energia contida nas oscilações. No entanto, ao contrário do "corpo negro", maior também será o comprimento de onda dominante. A despeito das diferenças entre os dois "domínios" dos fenômenos aqui apresentados, tal analogia pretende apresentar o espectro do "corpo negro" de forma mais "táctil", e será retomada adiante.

Eram de conhecimento dos físicos da época os fenômenos da radiação do "corpo negro". A partir dos dados experimentais, eles haviam determinado o gráfico de espectro (forma de sino). No entanto, não havia uma previsão teórica que desse conta de tais observações. De acordo com as previsões do eletromagnetismo clássico, um "corpo negro" ideal em equilíbrio térmico deve emitir uma certa quantidade de energia em cada frequência. Ao se calcular a quantidade total de energia emitida, observava-se que, para comprimentos de onda maiores, a teoria clássica concordava com a observação experimental, mas, para comprimentos de ondas menores, de acordo com a mesma teoria, a intensidade da radiação emitida tendia para o infinito, que não concordava com os experimentos.

Ainda no século XIX, o físico austríaco Wilhelm Wien, na busca por uma fórmula que se ajustasse ao espectro do "corpo negro", entre os anos 1894-1896, encontrou na distribuição de Maxwell e Boltzmann, que descreve o espectro do gás perfeito, certa semelhança que Ihe permitiu propor sua fórmula, descrevendo assim a emissão de radiação do "corpo negro", em concordância com as observações, em regiões do espectro das quais a teoria clássica não dava conta. Mas é precisamente em 1900 que o físico alemão Max Planck propõe uma fórmula que descreve bem, para cada temperatura, o espectro do "corpo negro". No entanto, de forma "enigmática", e de certa forma arbitrária, Planck apresenta uma estranha propriedade dos átomos a respeito da qual suas energias de oscilação estão de 
certa forma restritas a determinados valores. Tal restrição seria dada a partir de uma constante universal "h", futuramente chamada de constante de Planck $(h=$ $\left.6,62 \times 10^{-34} \mathrm{~m}^{2} \cdot \mathrm{kg} / \mathrm{s}\right)$.

Entramos então no século XX com questões "perturbadoras", questões essas que apresentavam resultados experimentais que não eram previstos pelas teorias físicas até então. Apesar da fórmula proposta por Planck, que dava conta de descrever com precisão o "misterioso" espectro do corpo negro, a teoria dos quanta de energia parecia fortemente arbitrária e deixava os físicos da época ainda com a sensação de falta de certa compreensão do fenômeno em questão. Destacamos aqui, mais uma vez, a busca por certo grau de inteligibilidade nas proposições da ciência. Mesmo com a solução do "conflito" entre as teorias vigentes e as observações experimentais, a teoria planckiana dos quanta de energia não parecia suficientemente "inteligível", mesmo esta sendo adequada à descrição do espectro do corpo negro.

É a partir dessa falta de compreensão mais profunda do fenômeno em questão que o brilhante físico alemão Albert Einstein, em 1905, apresenta sua grandiosa contribuição. Como destacamos anteriormente, Wien, no final do século XIX, já havia recorrido à fórmula de Maxwell e Boltzmann para o gás perfeito, o que apontava certa semelhança entre os dois domínios da Física. Segundo os físicos, um gás contido num recipiente era constituído por um número muito grande de partículas que se chocavam com as paredes desse recipiente e entre si; segundo eles, o gás no interior do recipiente possuía também um espectro que variava de acordo com a sua temperatura. No entanto, nos parece que Einstein tenha percebido (ou apostado) uma relação mais profunda do que aquela percebida por seu compatriota Wilhelm Wien. Na verdade, Einstein parece ter realmente apostado na analogia do gás perfeito para descrever o fenômeno da radiação do corpo negro (e não apenas na semelhança algébrica entre os respectivos espectros).

$\mathrm{Na}$ tentativa de tornar mais familiar a ideia de Maxwell e Boltzmann, Hofstadter e Sander (2013) propõem uma analogia que é também, por vezes, usada por professores do ensino médio ao apresentar o modelo mecânico de um gás perfeito. Tomemos o exemplo de uma mesa de bilhar sem atrito, sobre a qual muitas bolas iniciam o seu movimento a partir de uma tacada inicial e se chocam 
continuamente nas paredes da mesa assim como entre si. Mesmo sendo um exemplo a partir do qual os alunos conseguem imaginar a situação proposta, algumas inferências, não tão familiares, são necessárias a fim de que seja possível o que está sendo proposto. Como já destacamos anteriormente, não pode haver atrito entre a mesa e as bolas, e os choques que ocorrem devem ser perfeitamente elásticos. Uma vez respeitadas as condições, dada a energia inicial do sistema, qual será a velocidade "dominante" - a mais frequente - das bolas que se movem sobre a mesa? Ou, se pudermos estender a análise, qual seria então a distribuição de velocidades dessas bolas numa dada situação particular? Ainda que pareça complicado responder à segunda questão, é sim possível chegarmos a um resultado de distribuição de velocidades. De forma analógica, podemos determinar a distribuição de energia cinética de um gás perfeito de forma precisa, uma vez que conheçamos a sua temperatura (é o que chamamos de distribuição de "MaxwellBoltzmann").

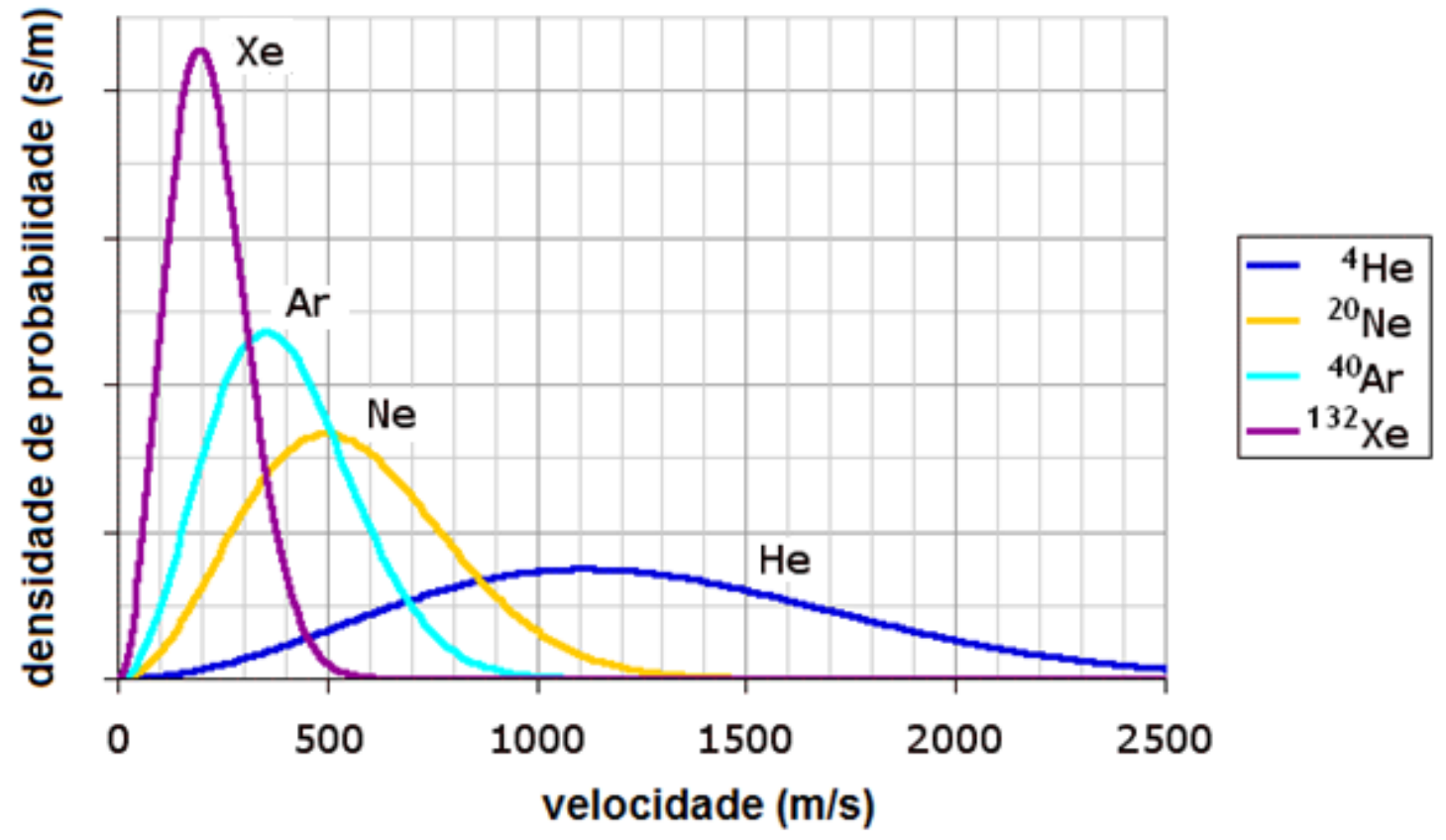

Figura 4.9 - Densidades de probabilidade da velocidade das moléculas de quatro gases nobres a $25{ }^{\circ} \mathrm{C}$. O pico de cada gráfico indica a velocidade dominante em cada gás na referida temperatura. 
A partir da análise dos dois sistemas físicos distintos - o corpo negro e o gás perfeito -, a intuição de Einstein percebe semelhanças profundas. No entanto, se retomarmos as analogias aqui apresentadas: das bolas lançadas numa piscina (corpo negro); das bolas em movimento numa mesa de bilhar (gás perfeito), dificilmente encontraremos semelhanças que não sejam, em princípio, superficiais. Talvez esta tenha sido a razão pela qual os físicos da época não tenham levado tão a sério a proposta de Einstein dos quanta de energia. No entanto, ele "enxergou" a "fraca" relação entre os dois fenômenos diferentemente, por isso Einstein escrevera em seu primeiro artigo de 1905 que ele havia notado uma surpreendente semelhança matemática entre as duas expressões na distribuição de energia para os dois sistemas.

Hofstadter e Sander (2013) destacam que, alguns meses antes de sua proposta analógica aqui descrita, Einstein havia já, com sucesso, proposto uma analogia entre um gás perfeito e um outro sistema físico, a saber, a análise microscópica de partículas coloidais no interior de um líquido, o que mostrava um movimento aleatório que estaria ligado ao movimento das partículas moleculares invisíveis (algo análogo a uma grande quantidade de mosquitos que se chocam aleatoriamente contra pequenas lâmpadas penduradas no teto por fios leves e finos), o que daria origem ao que foi chamado de "movimento browniano". Os autores supõem que Einstein possa ter partido de duas fontes de inspiração até chegar à sua analogia entre o corpo negro e o gás perfeito: a semelhança entre as fórmulas e sua analogia do movimento browniano.

Einstein toma como base os princípios da Termodinâmica, domínio da Física que ele considerava como mais fundamental e confiável. Ele vai utilizar a fórmula da entropia para cada um dos sistemas (radiação do corpo negro e o gás perfeito), a fim de tornar as duas expressões o mais próximas possível. Habilmente Einstein chega a um resultado cuja diferença entre as duas expressões fica reduzida a um simples expoente. Tal semelhança entre as duas expressões revela uma relação ainda mais profunda do que aquela prevista por Wien.

$\mathrm{Na}$ expressão da entropia do sistema correspondente ao gás perfeito, o expoente continha " $\aleph$ ", que representa o número de moléculas contidas no gás, enquanto na fórmula da entropia do corpo negro o que aparecia no lugar de " $\mathrm{"} \mathrm{era} \mathrm{a}$ 
expressão " $E / h . v$ ", que correponde, assim como "N", a um número puro. Afinal "E" corresponde a um valor de energia assim como " $h . v "$ ", mesmo que corresponda a um valor ínfimo, trata-se também de energia. Resumidamente, o que acabamos de apresentar foi a aproximação de dois sistemas físicos completamente diferentes (ao menos até aquele momento) de forma a diferenciá-los apenas por dois números puros, a saber, o número inteiro " $\aleph$ " e a expressão " $E / h . v$ ".

É a partir de sua forma unificadora de ver os fenômenos que sua analogia ganha significado. Einstein lança uma hipótese, quase inadmissível, indo mesmo de encontro às ideias outrora estabelecidas, propondo uma semelhança estrutural entre os dois sistemas físicos completamentes distintos, afinal o gás perfeito era descrito como um sistema corpuscular e obedecia às leis da mecânica corpuscular, enquanto o problema da radiação do corpo negro se enquadrava "sem dúvida" no conjunto de sistemas eletromagnéticos, e por isso deveria seguir as leis previstas nas sólidas equações de Maxwell. O jovem físico alemão ousa propor que as ondas eletromagnéticas emitidas por um corpo negro são compostas por pequenas quantidades discretas de energia, de forma análoga a " $\aleph$ ". Tal ideia concebia que 0 que podemos chamar de "particulas de radiação eletromagnética" possuía pacotes de energia cujos valores seriam dados por $h . v$, que seria o valor mínimo associado à frequência $v$. Tais "particulas de radiação eletromagnética" foram chamadas por Einstein de "quanta luminoso", o que conhecemos hoje como "fótons".

A ideia proposta por Einstein é tão revolucionária que serão necessários quase 20 anos até que ela seja admitida como tal. Afinal, não era de se esperar que uma teoria que apresentasse características corpusculares às ondas eletromagnéticas fosse aceita, uma vez que o debate sobre a natureza da luz havia sido superado há mais de um século. As experiências de Thomas Young na Inglaterra, os resultados encontrados por Augustin Fresnel na França, assim como as experiências do alemão Heinrich Hertz pareciam não deixar dúvidas quanto à natureza ondulatória da luz. Não era então razoável atribuir características corpusculares às ondas eletromagnéticas.

É só então após a experiência realizada em 1923 por Arthur Holley Compton, que mostra que uma onda eletromagnética, ao se aproximar de uma partícula carregada ( como o elétron de um átomo), transfere parte de sua energia cinética e 
troca com esta momento linear, como ocorre no choque entre duas partícula e não como preveem as equações de Maxwell, justamente como previa a teoria dos "quanta de luz" proposta por Einstein em seu primeiro artigo de 1905. Podemos dizer que "oficialmente" é nesse momento que a luz "recupera" seu "status corpuscular".

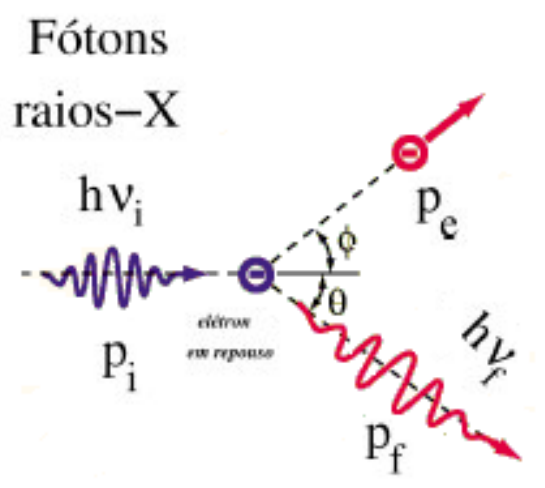

Figura 4.10 - Efeito Compton

Apesar de Einstein ter recebido o prêmio Nobel em 1921 pela "descoberta da lei do efeito fotoelétrico", não consideramos ser essa a sua maior contribuição, mesmo que vinculada ao primeiro de seus artigos de 1905. Na verdade, curiosamente, muitos físicos e professores de física parecem sugerir que o objetivo principal do referido artigo seria explicar o efeito fotoelétrico, mas não foi esse o caso. Segundo Hofstadter e Sander,

[...] o efeito fotoelétrico era, em 1905, tão recente que não havia dados suficientes de forma a caracterizá-lo como um fenômeno a ser explicado. Assim, o artigo de Einstein, longe de ter proposto a explicação de um célebre mistério, fornecia uma previsão portanto sobre um efeito pouco conhecido e pouco explorado, propondo então um teste experimental; tudo isso, portanto, ocupava apenas duas páginas da conclusão[...]". (HOFSTADTER e SANDER, 2013, p.557, tradução nossa)

Assim, acabamos de descrever, de forma resumida, o desenvolvimento da teoria dos quanta de Einstein com destaque ao seu pensamento analógico. Escolhemos o referido exemplo, presente na história da ciência do século $X X$, basicamente por dois motivos, primeiramente por se tratar do desenvolvimento da teoria dos quanta de luz, tópico fundamental na elaboração da teoria quântica, e em 
segundo lugar por se tratar de um cientista que possuía uma capacidade extraordinária de perceber e buscar o que há de essencial numa situação física. Como descrevemos anteriormente, outros físicos, como o físico alemão Wilhelm Wien, perceberam certa semelhança entre os fenômenos físicos do corpo negro e de um gás perfeito, no entanto a semelhança percebida por Einstein, e consequentemente a analogia traçada, era mais profunda que a de seu compatriota. Sua capacidade de estabelecer analogias "profundas" fez com que ele avançasse e desvendasse alguns mistérios da natureza.

No capítulo anterior, buscamos enfatizar o papel das analogias na formação dos conceitos em nossa estrutura cognitiva. Buscamos mostrar de que forma as analogias, dentro do par dialético analogia-categorização, desempenham um papel fundamental no desenvolvimento do sujeito, em cada uma das dimensões destacadas na perspectiva histórico-dialética, a saber, ontogêneses de sociogêneses e microgêneses. Entretanto, neste capítulo nosso foco se deu nas formas de pensamento mais elaboradas, dentre as quais nos concentramos no desenvolvimento do pensamento científico. Reforçando nossa preocupação de comunicar conceitos do domínio da Física Quântica, lançamos mão do exemplo dos "quanta de luz" proposto por Albert Einstein que, segundo nossa análise, se constitui em um dos mais impactantes e brilhantes exemplos da "fertilidade" do pensamento analógico. 


\section{CAPÍTULO 5}




\section{O USO DE ANALOGIAS E METÁFORAS NAS AULAS DE CIÊNCIAS}

Analogia e pensamento
analógico são essenciais tanto ao
trabalho quanto ao pensar
cientificamente. Algumas precauções
deveriam ser observadas quando
explicamos ou desenvolvemos uma
analogia: a analogia deve ser
interessante e familiar, e os atributos
compartilhados assim como os não
compartilhados necessitam ser
negociados com os estudantes.
Analogias são poderosas ferramentas
do pensamento que ajudam cientistas
assim como permitem as pessoas
obter sentido em situações do
quotidiano. No entanto, analogias
podem ser "espadas de dois gumes".
Sempre destaque com seus alunos os
limites da analogia em questão,
mostre a eles onde elas deixam de
funcionar. (Allan G. Harrison, 2008,
p.21)


Como forma de organização desse capítulo, primeiramente, apresentamos algumas definições de analogias e metáforas segundo trabalhos da área de ensino de ciências e de que forma estas têm se apresentado como elementos relevantes às discussões na referida área. Para isso, lançamos mão de alguns exemplos que elucidam determinadas posições a respeito da diferenciação entre os dois termos. Os artigos aqui utilizados sugerem o papel de cada um, analogia e metáfora, especificamente no ensino de ciências.

Em um segundo momento, discutimos as vantagens assim como alguns cuidados no uso de analogias e metáforas em atividades didáticas (sempre voltadas ao ensino de ciências). Para isso, mais uma vez, tomamos como base de nossas reflexões os trabalhos da área do ensino de ciências.

Em um terceiro momento, na tentativa de apresentar um exemplo de tipologia no uso de analogias em ações didáticas, ainda dentro do contexto do uso de analogias em atividades no ensino de ciências, apresentamos sistematicamente algumas categorias de analogias sugeridas no trabalho de Curtis e Reigeluth (1984). Inicialmente apresentamos três categorias gerais (formas) relativas ao uso de analogias. São elas: em formato de teste; apresentação oral; formato textual. Em seguida, apresentamos as categorias referentes ao formato textual presentes no artigo supracitado. Tais categorias reaparecem no capítulo $6 \mathrm{com}$ os devidos cuidados de recontextualização e sobretudo inseridas diretamente em nosso objeto de análise.

Por fim, visando explicitar nossa preocupação com a formação de professores a partir da presente ótica, retomamos o trabalho de Glynn et al. (1994) e apresentamos o trabalho de Venville (2008), intitulado "The Focus-Action-Reflection (FAR) Guide - Science Teaching Analogies". Pretendemos destacar como o planejamento do uso de analogias pode contribuir com o estabelecimento de ações docentes cada vez mais conscientes. No entanto, a respeito do uso de analogias como representações mediadoras, percebemos a necessidade de introduzir a concepção teórica adotada na presente tese. Para isso, o presente capítulo finaliza com a apresentação de alguns construtos da teoria da atividade de Leontiev na perspectiva de atividades mediadas por analogias. 


\subsection{Distinção entre Analogia e Metáfora}

Por vezes, no uso comum, as palavras analogia e metáfora são empregadas tendo significados muito parecidos. No entanto, levantamos elementos que mostram características diferentes. Concentramo-nos, inicialmente, nas definições encontradas em trabalhos vinculados à literatura especializada em Ensino de Ciências. Dessa forma, pretendemos apontar como tais termos têm sido tratados na referida área e de que forma tais definições são relevantes para a pesquisa.

Para definirmos o conceito de analogia tomaremos dois pontos de referência, o primeiro que será o sujeito particular (fonte), e o segundo, o sujeito particular (alvo). Diferentemente de métodos como a indução e dedução, nas quais uma das premissas ou conclusão é geral, a analogia está associada a um processo cognitivo que "parte" de um particular a outro particular.

Para BOZELLI e NARDI (2005), há distinção entre analogia e metáfora. Para os autores, analogia é uma comparação explícita e elaborada enquanto a metáfora é uma comparação implícita. RIGOLON e OBARA (2011), além de concordar com a diferenciação entre analogia e metáfora supracitada, diferenciam também a relevância e importância do uso de cada uma delas em atividades de ensino de ciências.

Segundo YERRICK et al. (2003), as analogias desempenham um papel fundamental na construção individual e coletiva do conhecimento científico, estas são colocadas a desempenhar um papel central no processo de desenvolvimento conceitual. Como tal, as analogias são postas como ferramentas indispensáveis no processo de aquisição de um novo conceito. Afinal, são elas que servem de "ponte" que une o domínio do conhecido ao domínio do que se deseja conhecer.

Alguns trabalhos apontam positivamente para o uso de analogias, com certo rigor metodológico, no entanto, desaconselham o uso de metáforas. Para Rigolon e Obara (2011), já existe uma metodologia do uso de analogias desenvolvida por Glynn et al. (1994), o Teaching With Analogies model (TWA), cuja forma estruturada visa a minimizar o reforço e/ou aparecimento de concepções alternativas. No entanto, no modelo TWA, não há opções "seguras" para o uso de metáforas, que 
são analogias condensadas, e não garantem apresentação de uma relação, de forma clara e explícita, entre os domínios estudados. Para os autores, esta questão é de tal importância que propõem um levantamento das concepções a respeito da compreensão dos significados dos conceitos de analogia e metáfora, tomando como seu espaço amostral de investigação uma turma do quarto ano de licenciatura em Biologia que cursava o disciplina Prática de Ensino II. De acordo com os autores:

[...] a pesquisa teve como objetivo geral investigar o conhecimento e o uso de analogias e metáforas como recurso pedagógico por licenciandos de Biologia em aulas regenciais para o Ensino Fundamental. Para tanto, dispôs-se a: investigar o grau de conhecimento desses licenciandos e o uso de analogias e metáforas, antes da intervenção pedagógica; elaborar e aplicar uma intervenção pedagógica para os licenciandos sobre analogias como recurso didático; e verificar as possíveis mudanças conceituais e procedimentais dos licenciandos sobre o uso de analogias, apos a realização da intervenção (RIGOLON e OBARA, 2011. p. 485).

Destacamos a importância dada pelos autores à diferenciação dos conceitos que incluem em sua pesquisa itens que levam a avaliar o número de professores em formação inicial que utilizam de forma indistinguível os conceitos de analogia e metáfora. Entretanto, como o interesse maior dos autores, assim como no nosso, foi o uso destas em atividades de ensino, destacamos que, na referida intervenção investigativa, os autores não se detêm na classificação dos conceitos, mas sobretudo se preocupam com a utilização de analogias e metáforas como ferramentas pedagógicas, salientando, porém, que o uso de metáforas deve ser evitado em aulas de ciências, devido ao grau de subjetividade e de generalidade associado a estas.

AUBUSSON et al. (2006) salienta que, a partir de meados do século XX, os filósofos têm aceitado que metáforas e analogias permeiam todo discurso e que são fundamentais para o desenvolvimento do pensamento humano. Portanto, da mesma maneira as metáforas e as analogias se apresentam com grande potencial no processo cognitivo. Diferentemente dos autores citados anteriormente, AUBUSSON et al. (ibid.) apontam as metáforas não apenas como uma figura de linguagem ou um fenômeno linguístico, mas como princípios fundamentais do pensamento e ação. No entanto, as analogias são mais específicas do que as metáforas, e, apesar de sua ampla utilização nos processos de comunicação cotidiana e de raciocínio, sua 
utilização em atividades de ensino é muitas vezes problemática, pois o uso de analogias específicas tende a ser feito sem a negociação necessária com os alunos.

Por apresentar um caráter mais subjetivo, alguns trabalhos na área de Ensino de Ciências têm levantado algumas preocupações quanto ao uso de metáforas em atividades de ensino. Por outro lado, o uso de analogias nas aulas de Ciências são mais presentes na literatura da área, fundamentalmente nas publicações nacionais, visto que a TWA tem sido apontada como uma ferramenta metodológica de grande potencial.

Apesar do esforço de alguns trabalhos no sentido de classificar de forma diferenciada o uso de analogias e o uso de metáforas em aulas de Ciências, outros autores, como NIEBERT et al. (2012), defendem a utilização de analogias e metáforas como ferramenta de ensino, sem fazer distinção entre os dois conceitos. Para NIEBERT et al. (ibid.), não somente em atividades de ensino, mas também o pensar e compreender a ciência sem metáforas e analogias não é possível. Ainda segundo os autores, uma análise no ensino de Ciências mostra que muitas vezes a utilização de metáforas e analogias não são vistas como ações intencionais dos professores. Uma de suas análises, que foi o levantamento de 199 metáforas e analogias em atividades de ensino, tendo como base uma análise metafórica, aponta que não basta apenas fazer uma conexão com os aspectos da vida cotidiana para comunicar ciência frutuosamente. Para NIEBERT et al. (IBID), metáforas e analogias com grande potencial como ferramentas pedagógicas precisam de fontes incorporadas. Estas fontes incorporadas são experiências cotidianas interpretadas. Aqui os autores chamam a atenção para a diferença entre aspectos da vida cotidiana e experiências cotidianas interpretadas.

Não esperamos ter esgotado as discussões a respeito da diferenciação entre os conceitos de analogia e metáfora, tampouco suas potencialidades de uso como ferramentas de ensino. Ao contrário, apresentamos nesse tópico elementos que serão de suma importância para a compreensão de nossa contribuição com os repertórios do uso de representações no ensino de Física.

Concluímos nossas breves considerações iniciais a respeito do tema, destacando que o uso de metáforas e analogias em atividade de ensino aparece em uma variedade de formas na literatura de educação científica. A analogia pode ser distinguida da metáfora, de certa forma, na seguinte perspectiva: em analogia 
podemos dizer que um particular A é como um particular B, enquanto, em metáfora, diríamos que um particular A é dito um particular B.

Ao longo de nosso trabalho, abordaremos tanto o uso de analogias como também o uso de metáforas utilizadas nas aulas de Física Quântica para alunos do Ensino Médio.

\subsection{Algumas Vantagens e desvantagens}

À medida que entendemos que o processo de relacionar conceitos através de analogias é uma parte básica do pensamento humano, uma analogia pode ser entendida como uma comparação baseada em semelhanças estruturais entre dois domínios de conhecimento diferentes, um familiar e outro não familiar. Muitos trabalhos têm reforçado a potencialidade dessa ferramenta no ensino e aprendizagem de Ciências (e.g. DUIT, 1991; GLYNN, 1991; HARRISON e TREAGUST, 2006), fundamentalmente de conceitos com maior grau de complexidade. No entanto, há trabalhos que apontam problemas em sua utilização (e.g. DUARTE, 2005; BROWN e CLEMENT, 1989).

Trata-se de uma primeira contradição relacionada ao uso de analogias e metáforas em atividades de ensino: ao mesmo tempo que essa ferramenta parece ser inerente às atividades relacionadas à aquisição de novos conceitos, há grande possibilidade de que esses conceitos sejam "carregados" de concepções errôneas não pertencentes aos mesmos. Na tentativa de superação da presente contradição, procuramos levantar e explicitar as vantagens e as desvantagens do uso da ferramenta em questão.

Partimos da consideração de que o uso de analogias em atividades de ensino pode trazer elementos que potencializem a compreensão de conceitos novos apresentados aos alunos. Tendo em vista tal consideração, apontamos que o propósito do uso de analogias em aulas de ciências é aproximar do aluno um novo objeto de estudo, por meio da comparação com um domínio de origem familiar. A expectativa é que sejam relacionadas por semelhança as propriedades do domínio de origem com o domínio de destino. 
Vamos tomar como exemplo o uso da analogia do sistema solar, ao se apresentar um dos modelos atômicos e, assim, dizer que o átomo "é como se fosse um sistema solar". Tal analogia tenta aproximar a estrutura abstrata, invisível, inacessível e presumidamente menos familiar, que é a estrutura atômica, das atividades que os alunos já aprenderam, comparando com o domínio mais concreto, e, mesmo que o sistema solar tenha sido apresentado a eles já em sua versão didatizada envolvendo atividades escolares ${ }^{41}$, e familiar de corpos celestes em movimento. Semelhanças estruturais seriam que os elétrons correspondem aos planetas, que orbitam em torno do Sol, que corresponde ao núcleo atômico, havendo um grande espaço vazio que os separa.

O argumento aqui apresentado parece, em princípio, ser suficiente para investirmos no ensino sob a presente perspectiva. No entanto, a falta de consenso apontado na literatura especializada da área não é sem importância. De fato, mais que uma falta de consenso, encontramos inúmeros trabalhos que destacam os cuidados que devem ser tomados ao lançar mão do uso de analogias como ferramentas voltadas para as atividades de ensino.

Com respeito ao exemplo supracitado, as analogias são semelhantes aos modelos científicos utilizados para representar os fenômenos. Estes só respondem por certos aspectos de um fenômeno do mundo físico, assim como no exemplo do sistema solar, como um análogo da estrutura atômica não fornece explicações suficientes para explicar o átomo sob o ponto de vista da física quântica.

A seguir, com o intuito de trazer elementos de ações práticas que permitam melhor visualização do que tentamos aqui explicitar, tomamos um exemplo retirado do livro Metaphor and Analogy in Science Education, editado por AUBUSSON et al. (2006), no qual aparece um relato de experiência de uma professora chamada Sally, referente a uma de suas turmas do $9^{\circ}$ ano (grade-9), correspondente ao nosso $9^{\circ}$ ano do Ensino Fundamental (HARRISON e DE JONG, 2004). O presente caso diz respeito ao conteúdo de circuito simples no qual a professora utiliza o exemplo de uma lanterna, a fim de explicar as relações entre as grandezas relevantes num

\footnotetext{
${ }^{41}$ Chamamos a atenção para as atividades escolares considerando que estas nem sempre têm as mesmas relações de "realidade" que as atividades outras de sua experiência com o mundo, nas quais os alunos constroem seus significados. Diferenciaremos no capítulo 3 o que Vygotsky chama de conceito espontâneo de conceito científico.
} 
circuito simples composto de geradores, interruptor, fios e resistências (lâmpadas). As figuras abaixo correspondem a modelos representativos de uma lanterna.
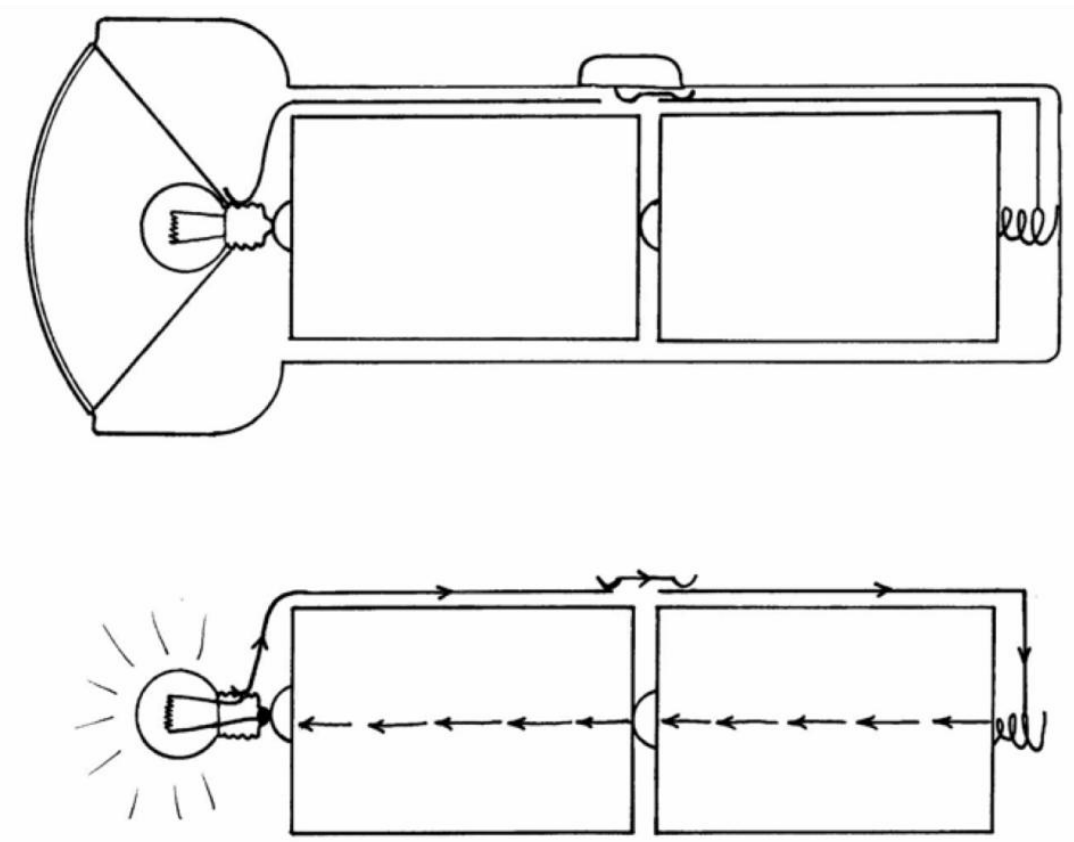

Figura 5.1 - Circuito simples de uma lanterna (HARRISON, 2008)

No entanto, a professora percebeu que muitos alunos haviam integrado às suas conclusões a respeito do tema a noção de que a corrente elétrica ia se esvaindo à medida que passava na lâmpada da lanterna, e por isso, com o passar do tempo, a "luz da lanterna" ficava mais fraca.

Com o intuito de vencer essa concepção não desejada na formação dos conceitos relacionados aos circuitos elétricos simples, a professora decidiu lançar mão do uso de uma analogia e assim superar esse conceito alternativo gerado ao longo das atividades anteriores. Para tentar explicar a ideia da conservação da corrente elétrica num circuito simples, como o caso da lanterna, ela lançou mão de uma analogia chamada por DUPIN e JOHSUA (1989) de analogia do trem contínuo, representada na Figura 5.2. 


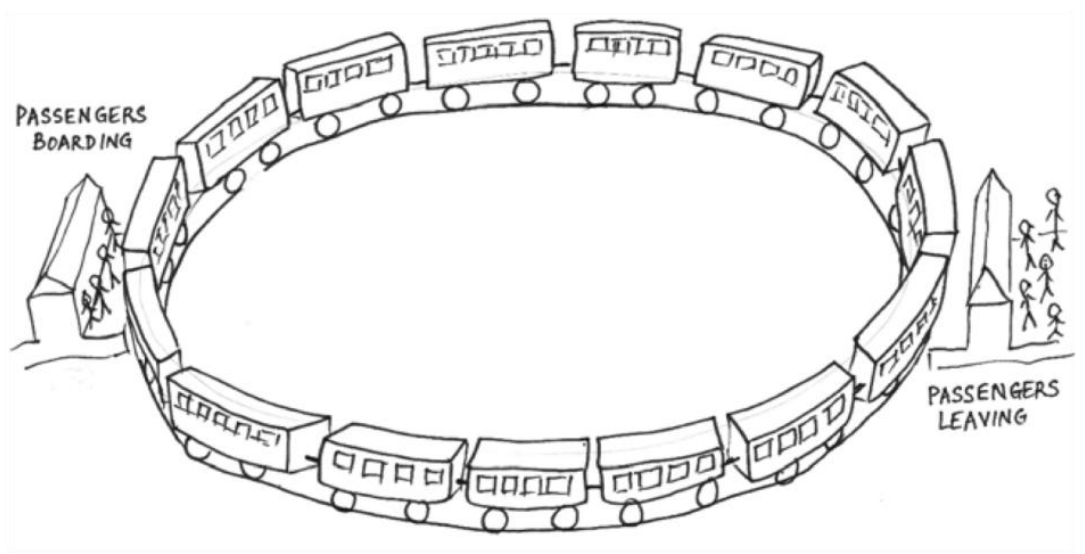

Figura 5.2 - Analogia do trem contínuo (HARRISON, 2008)

Nessa analogia o trem representa a corrente elétrica enquanto os passageiros representam a energia. $O$ trem contínuo está em constante movimento e leva passageiros de uma estação a outra. Os passageiros embarcam numa estação (que representa a bateria) e são "deixados" na outra estação (representada pela lâmpada). Essa alegoria mostra que o trem permanece estruturalmente inalterado, no entanto, os passageiros entram e saem da composição ferroviária. $O$ intuito era que os alunos percebessem que o que "fica" na lâmpada da lanterna não é a corrente elétrica, mas sim a energia que ela transporta.

No entanto, Sally percebeu que o uso dessa analogia trouxe outras concepções indesejadas como a de que a corrente elétrica para o referido circuito tem velocidade variável, afinal, segundo os seus alunos, como os passageiros poderiam descer na estação se o trem não parasse? Ou como eles embarcariam com o trem em movimento? Como Sally era uma professora muito atenta e perspicaz, percebeu algumas das concepções indesejadas. No entanto, ao invés de trazer tais concepções ao nível de discussão com os alunos a fim de mostrar os limites de uma analogia, a professora desistiu do uso da referida analogia. Apesar de "ter funcionado" em outros contextos e com outros professores, a professora julgou negativo em sua prática o uso da analogia do trem contínuo para apresentar as relações entre as grandezas presentes nos circuito elétricos simples. A analogia foi abortada, e a professora explicou a seus alunos o que estava acontecendo de 
errado com a analogia e reverteu para uma explicação clássica da diferença entre a corrente elétrica e energia.

A análise desse relato evidencia que o uso de analogias pode apresentar elementos positivos e negativos e, por isso, a escolha de analogias voltadas para atividades de ensino deve seguir alguns critérios a fim de evitar as concepções indesejadas. De fato, há um cuidado, em especial, no uso de analogias, afinal a identificação e a correlação de atributos entre a fonte da analogia e o alvo é idiossincrática e corroborada, nesse movimento, pela experiência pessoal. Assim, os alunos muitas vezes constroem as relações analógicas bem diferentes daquelas pretendidas pelo professor. Levando em consideração as presentes colocações, levantamos, propositadamente, as "desvantagens" no uso de analogias nas aulas de Ciências.

Segundo ZOOK (1991), ainda que as analogias elaboradas pelos professores sejam de fácil acesso aos alunos, o que representa um ponto positivo, afinal partir de um domínio familiar para os alunos é potencializar a sua compreensão, a tensão estabelecida se dá na medida em que tal aproximação não resulte na correlação planejada pelo professor (o que ocorreu no exemplo acima, de Sally com seus alunos). Por outro lado, se propomos que os alunos criem suas próprias analogias, eles encontram dificuldades, mas, quando conseguem criá-las, a correlação parece mais evidente. Segundo AUBUSSON (2006), são raras as situações em que alunos criam suas próprias analogias. No entanto, quando isso ocorre, a correlação entre o domínio de origem e o alvo se torna mais fácil. Sobretudo é raro para os estudantes gerar analogias apropriadas que não levem a concepções alternativas.

Com o intuito de fazer um levantamento a respeito de situações que os alunos consideram familiares, SILVA et al. (2005) realizaram uma pesquisa com 143 alunos da $3^{\mathrm{a}}$ série de 04 escolas de Ensino Médio da região de Santa Maria /RS. Segundo os autores, procurou-se determinar em que medida os alunos consideravam como familiares diferentes situacões análogas que Ihes foram apresentadas e quais as suas justificativas.

A figura 5 mostra uma tabela construída pelos autores baseada em atividades didáticas centradas em analogias, como parte do acervo do projeto de pesquisa denominado Linguagem e Formação de Conceitos: Implicações para o Ensino de 
Ciências Naturais, ligado ao Núcleo de Educação em Ciências da Universidade Federal de Santa Maria (UFSM) ${ }^{42}$.

Quadro 5.1 - Conjunto de atividades didáticas baseadas em analogias (Silva et al., 2005)

\begin{tabular}{|c|c|c|c|c|c|}
\hline \multirow{2}{*}{$\begin{array}{l}\text { Número } \\
\text { de } \\
\text { Ordem }\end{array}$} & \multirow[b]{2}{*}{ Situações Análogas } & \multicolumn{2}{|c|}{ Familiar } & \multicolumn{2}{|c|}{ Não Familiar } \\
\hline & & $\begin{array}{l}\text { Quanti } \\
\text { dade }\end{array}$ & $\%$ & $\begin{array}{l}\text { Quanti } \\
\text { dade }\end{array}$ & $\%$ \\
\hline 01 & Um circuito hidráulico & 84 & 59 & 59 & 41 \\
\hline 02 & O funcionamento de vasos comunicantes & 43 & 30 & 100 & 70 \\
\hline 03 & $\begin{array}{l}\text { O fluxo de pessoas num corredor de } \\
\text { shopping center }\end{array}$ & 126 & 88 & 17 & 12 \\
\hline 04 & $\begin{array}{l}\text { A modificação da trajetória de duas rodas } \\
\text { presas a um eixo ao mudarem de terreno }\end{array}$ & 80 & 56 & 63 & 44 \\
\hline 05 & $\begin{array}{c}\text { A passagem de parte de um feixe de } \\
\text { bastões (palitos de fósforo) incidindo numa } \\
\text { grelha (peneira de fendas) }\end{array}$ & 72 & 50 & 71 & 50 \\
\hline 06 & $\begin{array}{l}\text { A energia potencial de um sistema } \\
\text { mecânico (sistema corpo-mola) }\end{array}$ & 55 & 38 & 88 & 62 \\
\hline 07 & $\begin{array}{l}\text { O cheiro emanado de um vidro de perfume } \\
\text { aberto }\end{array}$ & 132 & 92 & 11 & 08 \\
\hline 08 & O fluxo de água em um cano & 123 & 86 & 20 & 14 \\
\hline
\end{tabular}

\footnotetext{
${ }^{42} \mathrm{O}$ Anexo 1 traz as referências de origem das atividades didáticas apresentadas na figura 5.
} 


\begin{tabular}{|c|c|c|c|c|c|}
\hline 09 & Uma máquina fotográfica & 122 & 85 & 21 & 15 \\
\hline 10 & O sistema planetário & 107 & 75 & 36 & 25 \\
\hline 11 & Um pudim de ameixas ou passas & 63 & 44 & 80 & 56 \\
\hline 12 & Uma cebola cortada ao meio & 124 & 87 & 19 & 13 \\
\hline 13 & Água escoando por um ralo & 118 & 82 & 25 & 18 \\
\hline 14 & Uma Malha ou um sistema ferroviário & 69 & 48 & 74 & 52 \\
\hline 15 & O sistema circulatório humano & 112 & 78 & 31 & 22 \\
\hline 16 & A intensidade da força gravitacional & 72 & 50 & 71 & 50 \\
\hline 17 & O campo gravitacional da terra & 62 & 43 & 81 & 57 \\
\hline 18 & Livros alocados em uma estante & 111 & 78 & 32 & 22 \\
\hline 19 & Energia potencial gravitacional & 57 & 40 & 86 & 60 \\
\hline 20 & Alunos em uma sala se aula & 123 & 86 & 20 & 14 \\
\hline
\end{tabular}

Esse levantamento é pertinente e torna-se fundamental na medida em que entendemos, conforme aponta DAGHER (1995), que o uso de analogias em atividades de ensino pode se apresentar como uma ferramenta com grande potencialidade do ponto de vista didático sob certas condições, uma das quais é a seleção de análogos que sejam realmente do conhecimento dos alunos.

Uma das colaborações do trabalho de SILVA et al. (IBID) é trazer a reflexão a respeito do que consideramos familiar aos alunos. $O$ conceito de familiaridade ganha aqui uma visão além do senso comum. Para os autores, o professor não pode considerar a priori uma situação análoga como plenamente conhecida dos alunos, ainda que esta faça parte do cotidiano deles. 
Aparecem na referida pesquisa situações nas quais os alunos, mesmo assinalando como familiares as situações/conceitos, evidenciavam a confusão conceitual presente na interpretação. Esse fato reforça a "vigilância" quanto às escolhas e uso de analogias em atividade de ensino, e particularmente, em nosso caso, no ensino de ciências.

Destacamos dessa pesquisa fragmentos das respostas de alguns alunos referentes à familiaridade de um circuito hidráulico. Segundo a pesquisa, $41 \%$ dos alunos assinalaram como não familiar a situação supracitada. Algumas justificativas dos $59 \%$ que consideraram familiar a situação de um circuito hidráulico apresentaram conceitos equivocados a respeito do domínio de origem, o que será remetido ao alvo. SILVA et al. (2005) apresentam algumas respostas de alunos,

\footnotetext{
"Uma hidrelétrica, a água faz gerar energia elétrica (com o impacto d'água)". (J.D)

"Um sistema de direção hidráulica de carros e pelo prefixo hidro deve ser algo com água". (M.M)

"Imagino que seja o ciclo por onde passa a água em uma usina hidráulica". (C.C) (SILVA et al., 2005, p.4)
}

No entanto, dentro do mesmo grupo de alunos, $86 \%$ deles respondem como familiar quando a situação apresentada é o fluxo de água em uma cano. Tal fato parece evidenciar que os alunos não veem correspondência entre o sistema hidráulico e o fluxo de água em um cano.

Dentre os resultados da pesquisa, destacamos as considerações a respeito das situações que apresentaram maiores índices percentuais de familiaridade. Identificamos um ponto de convergência entre estas, que é estarem relacionadas com o cotidiano dos alunos. Nós diríamos que a familiaridade se dá quando as situações apresentadas pelos professores são identificadas pelos alunos como episódios comuns a atividades nas quais eles já se inseriram em sua história pregressa.

$\mathrm{Na}$ tentativa de sintetizar o presente tópico, destacamos alguns pontos referentes às potencialidades do uso de analogias no ensino de ciências, em contraste com as dificuldades/problemas. De acordo com DUARTE (2005), algumas 
potencialidades usadas para defender a utilização de analogias no ensino de ciências são as seguintes:

1. Levam à ativação do raciocínio analógico , organizam a percepcão, desenvolvem capacidades cognitivas como a criatividade

e a tomada de decisões;

2. Tornam o conhecimento científico mais inteligível e plausível , facilitando a compreensão e visualizaçã o de conceitos abstratos, podendo promover o interesse dos alunos;

3. Constituem um instrumento poderoso e eficaz no processo de facilitar a evolução ou a mudança conceitual;

4. Permitem percepcionar, de uma forma mais evidente, eventuais concepções alternativas;

5. Podem ser usadas para avaliar o conhecimento e a compreensão dos alunos. (DUARTE, 2005, p.12)

No entanto, ainda que concordemos com as proposições aqui apresentadas, destacamos a dificuldade de verificar efetivamente se tais proposições são respondidas positivamente em um dado contexto especifico. Por outro lado, são apontadas algumas dificuldades /problemas que se colocam à utilização de analogias no ensino das ciências e que podemos resumir aos seguintes aspectos:

1. A analogia pode ser interpretada como o conceito em estudo, ou dela serem apenas retidos os detalhes mais evidentes e apelativos, sem se chegar a atingir o que se pretendia;

2. Pode não ocorrer um raciocínio analógico que leve à compreensão da analogia;

3. A analogia pode não ser reconhecid a como tal, não ficando explícita a sua utilidade;

4. Os alunos podem centrar-se nos aspectos positivos da analogia e desvalorizar as suas limitações. (DUARTE, 2005, p.12)

Tendo em vista as considerações acima, a fim de evitar correlações, indesejadas e potencializar a aprendizagem, identificamos que o uso de analogias deve ser resultado de planejamento criterioso. Apontamos que a eficiência deve-se, dentre outros aspectos, ao grau de familiaridade dos alunos com os domínios de 
origem relacionados com os análogos utilizados, e esta familiaridade está ligada à experiência cotidiana dos aluno. Isso significa que a utilização de certa analogia que tenha alcançado resultados positivos numa atividade didática, em certo contexto, não pode ser pensada como eficiente em qualquer situação generalizada.

\subsection{Potencializando o uso de analogias em atividades de Ensino.}

Como apresentamos em nosso estudo bibliográfico, há uma preocupação com o uso de analogias e/ou metáforas no ensino de ciências, caracterizada pelo volume de produção de artigos relacionados ao referido tema nos últimos 20 anos. Além disso, partimos da concepção pela qual o uso de analogias juntamente com o processo de categorização são fundamentos básicos do pensamento humano, dando a estes um status central no processo cognitivo. Sendo assim, reconhecemos que o uso de analogias é parte presente nas aulas de ciências, e isso justifica o cuidado e a necessidade de compreendermos os processos envolvidos nesta atividade.

\subsubsection{Classificação das analogias quanto à forma}

A fim de superar algumas dificuldades vinculadas ao uso de analogias nas aulas de ciências, propomos, de acordo com a literatura especializada na área, fazer uma classificação das analogias presentes em trabalhos que visam a atividades de ensino. Propomos fazer uma classificação das analogias tendo como base 0 trabalho de CURTIS e REIGELUTH (1984), intitulado The Use of Analogies in Written Text. Apesar de se tratar de uma pesquisa realizada há quase 30 anos, quando comparada a sistematizações quanto ao uso de analogias nas aulas de ciências mais recentes, julgamo-la pertinente para as reflexões propostas em nossa pesquisa. Além disso, ainda que o referido trabalho tenha se baseado em analogias presentes em livros didáticos, destacamos que a classificação por eles proposta vem ao encontro de um dos objetivos de nossa pesquisa, a saber, colaborar com a formação do professor-autor consciente de suas ações em sala de aula, mais 
especificamente do uso de analogias. Afinal, conforme explicitaremos no presente capítulo, as categorias apresentadas pelos autores permitem, em certo grau, trazer ao nível de consciência as relações propostas nas analogias utilizadas. $\mathrm{O}$ argumento aqui apresentado é reforçado na afirmação de Glynn (2007), na qual ela salienta que professores geralmente fazem uso de analogias em suas aulas de forma automática e inconsciente.

A classificação aqui apresentada se dá na forma como as analogias se apresentam nas atividades de ensino. A primeira forma com que uma analogia pode ser apresentada, segundo CURTIS e REIGELUTH (ibid.), é em formato de teste. Tal utilização é do tipo:

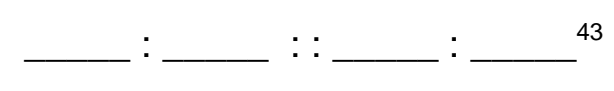

Nesse formato, o uso de analogias demanda do aluno o reconhecimento da estrutura do análogo (origem) e uma transferência para o alvo (destino). Nesse caso, por se tratar da estrutura de um teste, os dois primeiros são fornecidos para o aluno descobrir/reconhecer a relação entre eles. A terceira lacuna também é dada pelo professor, e o aluno deve preencher a quarta tomando como base a relação entre as duas primeiras. Busca-se a verificação do reconhecimento ou não da semelhança entre o análogo e o alvo. Um exemplo de um teste analógico seria:

mosca : voa : : baleia :

(a) grande ; (b) mamífero; (c) nada; (d) preta

No primeiro par de palavras (mosca, voa), estão relacionados um animal e seu modo de locomoção e, portanto, o segundo par deve compartilhar uma relação (análoga) similar. Portanto, a resposta correta é (c) nada. No entanto, se

\footnotetext{
43 As quatro lacunas apresentadas na estrutura representativa visam à relação por correspondência/semelhança. A segunda lacuna está relacionada à primeira, da mesma forma que a quarta se relaciona à terceira.
} 
mantivéssemos os animais (mosca e baleia) e a relação fosse diferente, a resposta também seria diferente. Como no caso:

mosca : pequena : : baleia :

(a) grande ; (b) mamífero; (c) nada; (d) preta

Como agora o primeiro par de palavras (mosca, pequena) relaciona um animal ao seu tamanho, o segundo par deve compartilhar novamente uma relação (análoga) similar. Dessa vez, a resposta correta é (a) grande.

A segunda forma de se apresentar uma analogia é oralmente. Portanto, chamamos de analogia oral as que utilizamos num contexto menos formal, o que pode incluir a comunicação oral. Aqui, as analogias são usadas para explicar e elucidar questões num contexto onde prevaleça o discurso. Esta forma de uso das analogias está muito presente nas práticas dos professores ao tentar explicar, por exemplo, um tópico novo abstrato ou de difícil compreensão. Inclusive estas podem assumir inumeráveis formatos, dependendo do contexto e da capacidade de ser compreendida. Uma das vantagens deste formato é a possibilidade de receber um feedback. Tal fato permite a reutilização da analogia para esclarecer ou até buscar outra.

A terceira e última forma que apresentamos é a analogia textual. Esta é diferente da oral por não permitir feedback. Por não contar com essa "ferramenta", deve antecipar qualquer imprecisão ou incompatibilidade que possa confrontar a experiência ou a "capacidade de compreensão do aluno" ${ }^{44}$, fornecendo uma explicação clara tanto quanto possível na sua apresentação.

Esta também se diferencia da analogia em forma de teste por pretender estrategicamente aproximar dos alunos temas geralmente de maior abstração ou de maior complexidade. Trata-se de uma ação intencional na busca de melhorar a

\footnotetext{
${ }^{44}$ Colocamos a "capacidade de compreensão do aluno" entre aspas por estar de acordo com nosso referencial sócio-histórico de que essa capacidade não é dada a priori mas construída através da privação das experiências e do acesso às atividades que lhe garantem o desenvolvimento. Para Leontiev (1967) "[...] a criança não possui "aptidões preparadas de antemão" para realizar essas tarefas, como, por exemplo, falar um determinado idioma ou perceber relações ge ométricas. $A$ formação dessas aptidões acontece em consonância com o processo de apropriação , ou seja, de domínio, pelo indivíduo, do patrimônio cultural criado pela humanidade ao longo do processo histórico.(Leontiev apud Duarte, 2007, p.54 )
} 
compreensão cognitiva do aluno, quando um conteúdo mais complexo the é apresentado. As ações associadas às analogias textuais não buscam, em princípio, determinar o nível geral do aluno no sentido de avaliar sua capacidade analógica.

\subsubsection{Algumas categorias das analogias textuais}

Partirmos de categorias que surgiram como resultado de um estudo descritivo no qual se propôs fazer uma análise de 216 analogias retiradas de 26 livros didáticos do Ensino Fundamental e Médio ${ }^{45}$. Neste trabalho foram identificadas as analogias e organizadas em diversas categorias, que foram, então, sintetizadas em um sistema de classificação. Apesar de o referido trabalho ter se desenvolvido a partir de um conjunto de analogias textuais, nossa pesquisa tenta apontar que algumas das categorias aqui descritas podem ser generalizadas para a forma oral, apresentando-se, assim, como elemento de potencial colaboração para as reflexões do professor quanto ao uso e às escolhas de analogias em suas ações didáticas.

\subsubsection{Relação}

A primeira categoria das analogias que apresentamos é a de relação. Existem duas principais formas de relação analógica em que o análogo e o alvo podem partilhar. A primeira delas ocorre quando estes se assemelham por aparência física geral ou têm a mesma forma de construção. Esta é a que denominamos de relação estrutural. Um exemplo de uma analogia com um relacionamento estrutural é " Cada célula da cebola é algo como um quarto. Ele tem um 'chão' e um 'teto', bem como quatro 'paredes' "(Smith and Lawrence apud Curtis, 1984, p.103).

Outro tipo de relação analógica é a que compara o funcionamento do análogo com o do alvo. Essa relação foi denominada relação funcional. São exemplos de relação funcional analogias vinculadas aos mecanismos de homeostase: feedback, o

${ }^{45}$ Curtis R. V. , \& Reigeluth C. M. (1984). The Use of Analogies in Written Text. Instructional Science 13 99-117. 
feedback negativo é a reação pela qual o sistema responde de modo a reverter a direção da mudança, dando a entender que manter estáveis as variáveis permite a manutenção da homeostase. A termorregulação é outro exemplo de feedback negativo. Uma analogia de relação funcional bastante utilizada é correlacionar o funcionamento de um termostato à termorregulação. Quando a temperatura do interior de um refrigerador atinge o valor programado, um sinal desliga a geladeira, de forma análoga, quando a temperatura corporal sobe, ou desce, receptores na pele e no hipotálamo sentem a alteração, desencadeando uma ordem no cérebro que dá início a uma reação no sentido de gerar ou libertar calor, conforme seja o caso.

Um terceiro tipo de relação analógica seria a combinação entre a relação estrutural e a relação funcional. Para melhor exemplificar tal relação "tomamos emprestado" mais um exemplo relacionado ao ensino de Biologia:

A célula pode ser comparada, de maneira bem simples, com uma fábrica. Através das portas da fábrica, chega o material que será usado para a fabricação de seus produtos, esse processo requer o emprego de energia e funcionários devidamente preparados para sua função específica. Contudo, para que haja um bom funcionamento da fábrica, é necessário um corpo administrativo, responsável por organizar o trabalho de cada funcionário e pelo contato com o mundo exterior.

Tudo isso ocorre no interior da fábrica, que é delimitada por seus muros. De maneira semelhante encontraremos a vida celular. Delimitada por uma membrana (membrana plasmática), responsável por separar o conteúdo interno da célula do meio externo, encontraremos os organóides (espécie de funcionários com atividades específicas), e o núcleo, que funciona como o corpo administrativo, mantendo o bom funcionamento da célula e administrando o contato com o meio exterior. 


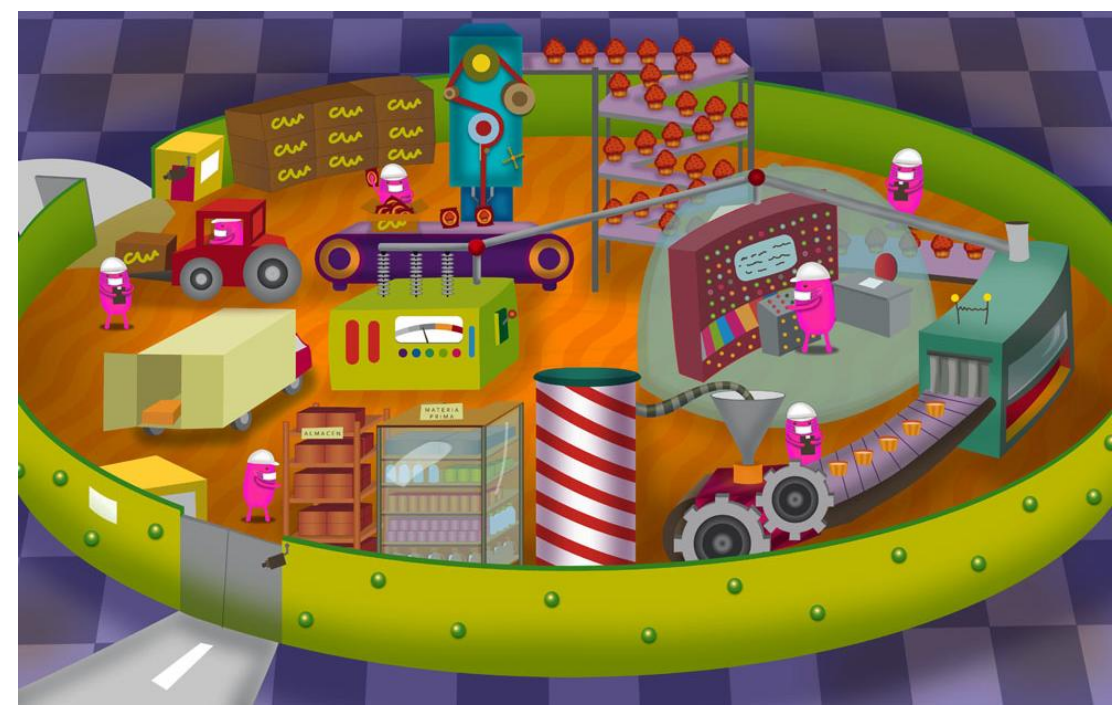

Figura 5.3 - Uma célula animal como uma fábrica.

\subsubsection{Formato de Apresentação}

Quanto à apresentação, há duas categorias nas quais classificamos as analogias. A primeira tem o formato de analogia escrita ou verbal. Neste formato, a apresentação das analogias é feita exclusivamente com o uso de palavras. Ainda que isso remeta ao aluno qualquer representação mental de ordem pictórica, esse formato permite que a construção se dê associada com a experiência de cada indivíduo, o que provavelmente irá resultar em representações distintas e particulares.

O outro formato aqui apresentado é o pictórico-verbal. Neste outro, a analogia escrita é forçada por uma ou algumas imagens. Aqui a representação pictórica não fica a cargo dos alunos, antes é propositalmente apresentada, evitando assim uma maior "dispersão" da forma pictórica do análogo, que foi previamente pensada e planejada. Essas imagens podem ser apresentadas em forma de desenho ou fotografia. Nas ações didáticas do professor, encontramos ambos os formatos de apresentação, no entanto, percebemos em nossa análise de caso ${ }^{46}$ que o primeiro formato (escrito ou verbal) é mais comum em suas práticas. Nesse caso, destaca-se quase que exclusivamente o formato verbal.

\footnotetext{
${ }^{46}$ Aulas de dois professores do Ensino Médio foram videografadas e fizemos uma análise do uso de analogias nas aulas de Física Quântica. Esta análise será apresentada no capítulo 5.
} 
No formato pictórico-verbal, as analogias fornecem uma visualização direta, enquanto analogias verbais requerem que essa representação visual seja desenvolvida pelos alunos.

\subsubsection{Estado}

A categoria aqui apresentada trata do estado de uma analogia. Quanto ao estado, uma analogia pode ser de conteúdo concreto ou abstrato. Na verdade, os estados podem ser apresentados em três combinações possíveis, a saber, concreto/concreto - onde o análogo e 0 alvo são de natureza concreta, abstrato/abstrato - onde 0 análogo e 0 alvo são de natureza abstrata, e concreto/abstrato - onde o análogo é de natureza concreta e o alvo é de natureza abstrata $^{47}$.

Segundo CURTIS e REIGELUTH (1984), como o uso de analogias em aulas de ciências busca se apresentar como ponte entre o domínio de conhecimento familiar e o domínio desconhecido, entre o simples e o complexo e abstrato, já era previsto que a maioria das analogias encontradas fossem de estado concreto/abstrato, assim como se esperava que seria mais raro encontrar casos de analogias de estados concreto/ concreto e abstrato/abstrato.

\subsubsection{Posição}

Em relação à sua posição, um análogo pode se apresentar em diferentes momentos da ação didática pretendida. $\mathrm{O}$ análogo poder ser apresentado, no início da ação didática como introdução de um novo tópico a ser aprendido, durante ou ao final da atividade de ensino. Quando apresentada no início da ação didática, a analogia será categorizada como organizador prévio. Como tal, este pode se apresentar como um "pano de fundo" fornecendo informações necessárias para o

\footnotetext{
${ }^{47}$ Apesar de a combinação abstrato/concreto ser possível, na qual o análogo é de natureza abstrata e o alvo de natureza concreta, a pesquisa na qual nos baseamos para apresentar as presentes categorias não encontrou, dentre as 216 analogias analisadas, nenhuma analogia de estado abstrato/concreto. Tal fato já era de se esperar, afinal o uso de analogias em atividades de ensino tem por objetivo auxiliar na explicação de conteúdos natureza abstrata ou complexa.
} 
aprendizado do novo conceito, desconhecido (HAYES e TIERNEY,1980). Além disso, a analogia como organizador prévio permite que o aluno retome a relação analógica em vários momentos da ação didática.

Nessa perspectiva, outra forma de posicionar a analogia é apresentá-la em algum momento durante a ação didática. Isso pode ocorrer num ponto qualquer em que o conteúdo seja mais abstrato ou mais complexo. A categoria da analogia nesse contexto é a de ativador incorporado. Nessa posição a analogia não só permite o esclarecimento de informações precedentes, mas também pode conduzir de forma satisfatória o aprendizado do novo conceito.

Por último, a analogia pode ser usada no momento final da ação didática. Sendo assim, esta age como uma síntese, um "fechamento" do conteúdo que foi previamente apresentado e, assim, apresenta-se como conclusão e/ou como preparação da ação didática seguinte.

\subsubsection{Nível de elaboração}

Quanto ao nível de elaboração, o mais básico é denominado analogia simples. Uma analogia simples deve ser composta basicamente por três elementos, a saber, o tópico (alvo ou destino), o análogo e um conector do tipo "é como" ou "pode ser comparado a". Segundo CURTIS e REIGELUTH (ibid), esse tipo de analogia não aparece com frequência nos livros didáticos porque tais analogias exigem dos alunos compreender as relações envolvidas entre o análogo e 0 alvo, incluindo suas semelhanças e diferenças. Ainda segundo os autores, esse tipo de analogia deve ser usado em tópicos em que as relações entre o análogo e alvo sejam óbvias com pouca, ou nenhuma dificuldade.

Um exemplo utilizado no referido trabalho é "A medula espinhal é como uma cabo extenso que se estende para baixo através das vértebras ocas" (BRANLEY, PELIA e URBANO apud CURTIS, 1984, p.110). 


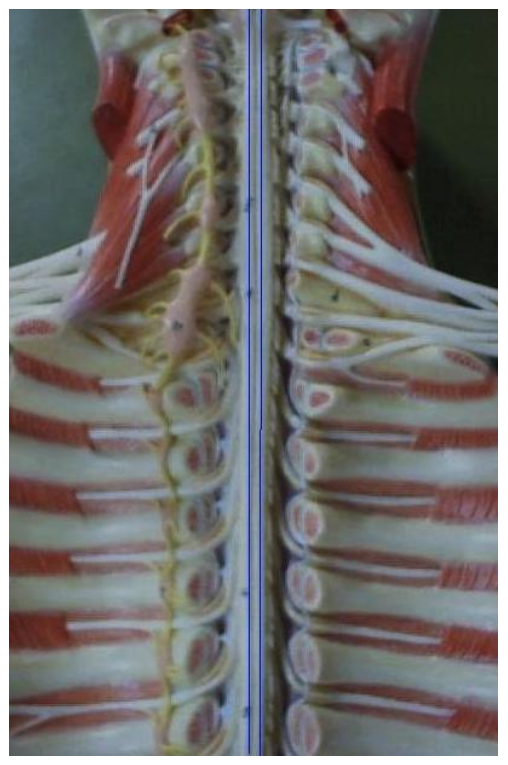

Figura 5.4 - Medula Espinhal.

Uma analogia simples pode ser enriquecida na medida em que as relações entre o análogo e o tópico são explicitadas. Além disso, numa analogia enriquecida são evidenciadas as suas limitações. Há diversos graus de fundamentos e limitações nas analogias, sendo assim são destacadas as relações analógicas presentes para potencializar a compreensão do tópico que se apresenta como novo conteúdo. Tendo em vista as ponderações dos autores e ressaltando nosso objetivo final de pesquisa, a saber, o professor em ação, esperamos que esse tipo de elaboração esteja presente em grande parte das ações didáticas que envolvam o uso de analogias. Sobretudo, diferentemente dos livros didáticos, as aulas dos professores permitem intervenções sincrônicas.

Num nível mais elaborado de enriquecimento das analogias, encontramos diferentes fundamentos (motivos) de único análogo para ensinar um único tópico, ou vários análogos com seus respectivos fundamentos e limitações a fim de ensinar também um único tópico. Este nível de elaboração analógica é denominada analogia estendida. O esquema de cada um dos três níveis de elaboração é representado na Figura 5.5. 

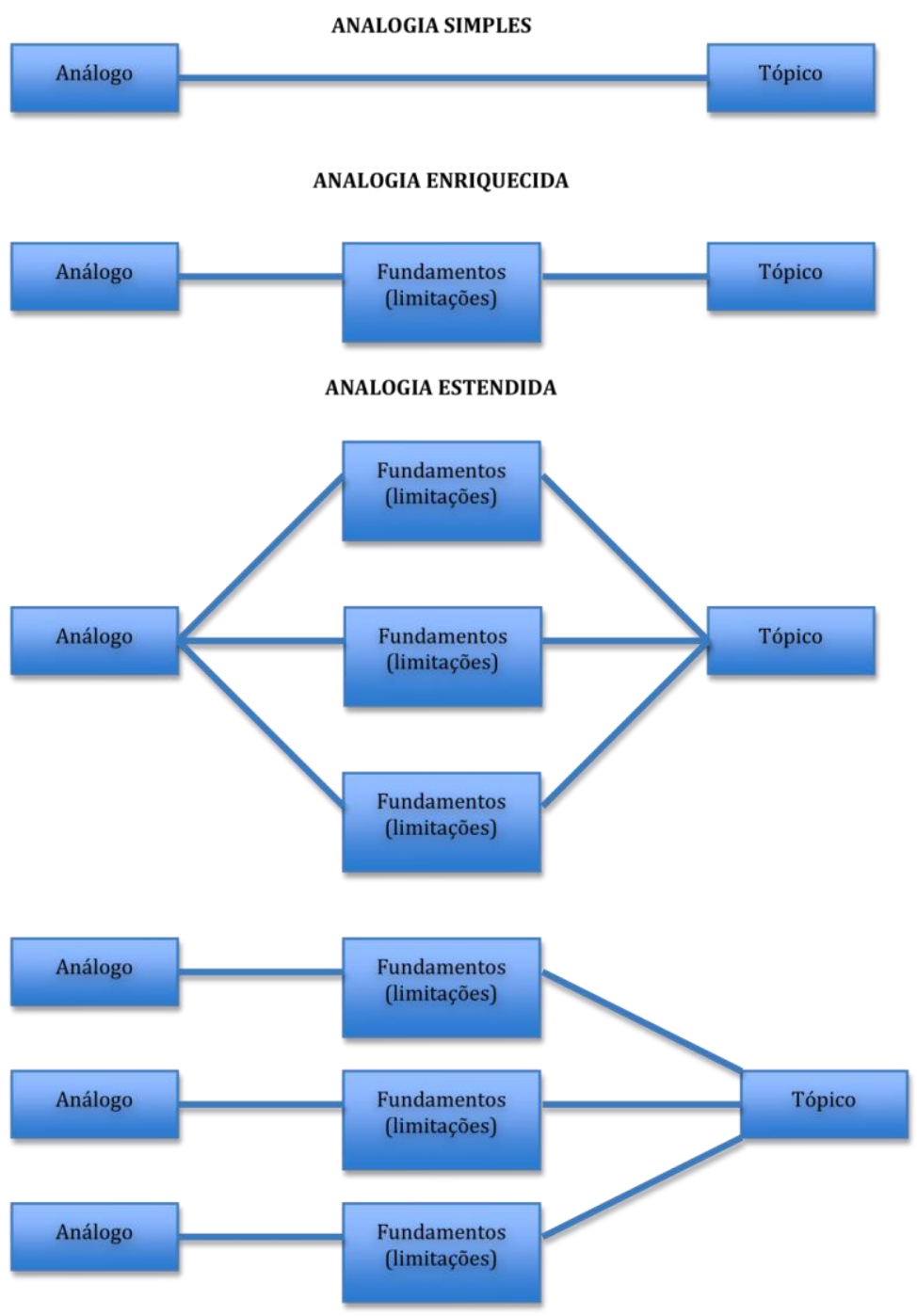

Figura 5.5 - Três níveis de elaboração de analogias.

\subsubsection{Orientação prévia}

A última categoria que apresentamos identifica e classifica a presença de prévia orientação dos elementos, estrutura e funcionamento dos análogos, assim como das estratégias presentes na relação entre o análogo e o tópico. As subcategorias aqui levantadas são: quanto à explicação ligada ao análogo; quanto à explicitação das estratégias cognitivas; quanto à explicação ligada ao análogo e explicitação das estratégias cognitivas; ausência de ambas. 
Como já apresentamos, baseados na literatura especializada da área dos últimos 20 anos, o uso de analogias em atividades de ensino tem sido apontado como uma estratégia de grande potencial na aprendizagem de conceitos em ciências, onde a analogia se coloca como uma ponte entre o conhecimento familiar e um domínio desconhecido. No entanto, como destaca Curtis e Reigeluth :

Supõe-se frequentemente, principalmente por autores de livros didáticos, que 0 aluno conhece 0 análogo a ser utilizado e a estratégia cognitiva do pensamento analógico. Isso pode explicar por que, das 216 analogias, 106 (49\%) não faz nenhuma tentativa de descrever o análogo e / ou estratégia cognitiva antes de apresentar o tema. Esta suposição de conhecimento do aluno antes, no entanto, pode estar incorreta. (CURTIS e REIGELUTH , 1984, p.112)

\subsection{Ações conscientes no uso de analogias em aulas de ciências.}

No presente capítulo, nossa análise está concentrada no uso de analogias em atividades didáticas em aulas de ciências. Até o presente momento, apresentamos as concepções de analogias e metáforas adotadas historicamente nos trabalhos na área de ensino de ciências; ponderamos, numa relação vantagens e desvantagens, o uso de analogias em aulas de ciências; e, em seguida, na tentativa de melhor compreender o conjunto de analogias assim como o seu uso didático, apresentamos algumas categorias. Mesmo que a discussão sobre o planejamento de tal atividades já tenha sido iniciada, julgamos que, até então, nossa abordagem teve um caráter sobretudo normativo.

No presente tópico, ressaltamos a importância de incorporar discussões a respeito do planejamento docente referente ao uso de analogias nas aulas dos professores de ciências. Pretendemos destacar que tais reflexões deveriam fazer parte da formação inicial dos professores. De acordo com VENVILLE (2008), como a maioria dos professores de ciências não tem em sua formação inicial questões relativas ao uso de analogias, é de se esperar que o uso de analogias em aulas de ciências não seja tão presente, ao menos de maneira planejada e sistematizada. $\mathrm{Na}$ perspectiva do autor, observações apontam para sistematização e elaboração de um modelo pedagógico visando à apresentação mais efetiva de analogias em aulas de ciências. Ainda segundo o autor, tal modelo poderia ser usado na formação inicial 
assim como na formação continuada, a partir da qual os professores lançariam mão de analogias segundo suas preferências.

\subsubsection{Uma perspectiva reflexiva}

Apresentamos algumas questões a respeito do uso de analogias em aulas de ciências com uma perspectiva reflexiva. Na verdade, a perspectiva reflexiva aqui proposta é comprometida com a contribuição na formação de ações conscientes por parte dos professores, neste caso, agentes de escolha e uso de analogias em atividades didáticas. Concentramo-nos basicamente em dois trabalhos encontrados na revisão bibliográfica. O primeiro, o artigo de Glynn (1991) intitulado "Explaining science concepts: A teaching-with-analogies model (TWA)" e o segundo, o trabalho de Venville (2008) intitulado "The Focus-Action-Reflection (FAR) Guide - Science Teaching Analogies". As escolhas dos referidos artigos foram baseadas fundamentalmente em dois critérios, a saber, a pertinência do trabalho, tendo em vista sua citação em diversos outros trabalhos relacionados ao presente tema, e a convergência com o objetivo supracitado.

Pretendemos, através de alguns exemplos, reforçar a ideia do uso de analogias em aulas de ciências como uma ação potencial na explicação de temas com certo grau de abstração, e que são relativamente distantes das atividades regulares dos alunos, e destacar a importância de uma ação planejada e orientada. Buscamos, para isso, contribuições nos trabalhos acima destacados, os quais apontam modelos que podem auxiliar o professor.

\subsubsection{Teaching -With-Analogies model}

Rigolon e Obara (2011) apresentam o "TWA model" desenvolvido por Glynn (1991) e apontam certa estrutura que dá ao uso de analogias no ensino de Ciências um status de ferramenta com forte potencial. $\mathrm{Na}$ intenção de reforçar a pertinência do referido tema, Glynn (ibid) estabelece seis passos que, de forma ideal, podem ser levados em consideração ao se ensinar com analogias: 1) Introduzir o assunto alvo; 
2) Sugerir o análogo ; 3) Identificar as características relevantes do análogo ; 4) Mapear similaridades entre análogo e alvo ; 5) Estabelecer as diferenças entre os dois domínios; 6) Esboçar conclusões.

Os autores reiteram a relevância da utilização de analogias como ferramenta auxiliar ao professor, reforçando que, mediante uma metodologia própria, tal uso permite um redimensionamento na compreensão do papel da memória no processo de assimilação de novos conceitos, tendo em vista que no processo analógico vínculos de reflexão e busca por elementos de semelhança podem minimizar a atividade de memorização do aluno.

Reforçando a necessidade de sistematizar o uso de analogias com fins didáticos, destacamos a observação feita por Glynn (ibid) na qual afirma que geralmente os professores e autores de livros didáticos não têm consciência das possíveis relações que surgem ao lançarem mão de analogias na tentativa de apresentar um novo tópico ou explicá-lo, eles as usam de forma automática. Ao contrário desta postura "espontânea" assumida por parte dos autores de analogias, queremos destacar que é imprescindível trazer essas atividades ao nível da consciência de seus atores, a fim de extrairmos o que há de melhor dessa ferramenta com grande potencial de uso.

A fim de explicitar a importância dos passos sugeridos por Glynn, apresentamos um exemplo de uso de analogias no qual destacamos, na ação do professor, cada um dos itens sugeridos. Trata-se de um diálogo fictício entre uma professora, Miss Davis, de ciências do seventh grade ( $7^{\circ}$ ano do ensino fundamental - média de idade dos alunos entre 12 e 13 anos) e seu aluno, John:

John: Professora, estou preocupado com a próxima prova de ciências.

Miss Davis: Ah, me fale o que está te deixando inseguro?

John: São essas coisas de eletricidade e circuitos elétricos no nosso livro.

Miss Davis: Eletricidade pode ser uma unidade complicada, tudo bem. Você leu o capítulo com atenção?

$\mathrm{J}$ : Com certeza, professora. Aliás, várias vezes. A leitura é difícil. Todos esses termos novos me confundem.

$M D$ : Me diga alguns dos termos que o deixaram confuso. 
J: Eu creio que sei o que é um "circuito", mas não estou certo quanto ao significado de "voltagem" a "resistência".

$M D$ : Quais foram os outros termos ou ideias relacionadas a eletricidade que você já leu?

J: Humm, Eu li sobre "fios", "baterias" e "interruptores".

$M D$ : Isso, esses são partes importantes de um circuito elétrico. Você parece lembrar todas as principais ideias de sua leitura. Você poderia colocar essas ideias juntas e me explicar como funciona um circuito elétrico?

J: Ah, não. Este é o problema. Eu não consigo imaginar como essas coisas de eletricidade funcionam.

$M D$ : Bem, não desanime, John. Você aprendeu bastante coisa a partir do texto.Deixe-me ver se posso te ajudar colocando esses elementos juntos, então você vai compreender como funciona um circuito elétrico. Talvez uma analogia possa ajudar. Você se lembra quando você e sua turma montaram um aquário na aula?

\section{J: Com certeza!}

$M D$ : E você conseguiria me explicar como a água do aquário circulava?

$\mathrm{J}$ : Nesse caso é fácil, diferente das coisas de eletricidade. Quando você explicou como a água circulava eu podia na verdade ver a bomba e o filtro.

$M D$ : Exatamente! Bem, agora eu ajudá-lo a "ver" como o circuito elétrico funciona através da comparação com a circulação da água no aquário. Olhe para o aquário da sala enquanto eu descrevo outra vez como a água flui através dos tubos. Uma corrente é esboçada através de um tubo a partir do aquário por meio de uma bomba que controla a pressão. A água então flui através de um filtro, que reduz 0 fluxo e retém as impurezas. Finalmente, a água retorna para o aquário através de um tubo. Você lembra e entende, John?

$\mathrm{J}$ : Sim, professora.

$M D$ : Excelente. Agora pense a respeito da seguinte questão: $O$ que corresponde a água no circuito elétrico? Ou seja, O que flui no circuito elétrico?

$\mathrm{J}$ : A eletricidade.

MD: Exatamente! Muito bom. Agora, a água é levada do aquário até o filtro e depois de volta ao aquário através de tubos de plástico. O que esses tubos de plástico correspondem num circuito elétrico?

$\mathrm{J}$ : Os fios de metal. 
$M D$ : Está correto mais uma vez. Agora, no aquário, a bomba gera a pressão responsável por mover a água através dos tubos. Num circuito elétrico, o que gera "pressão" responsável pelo movimento da eletricidade através do circuito?

\section{$\mathrm{J}$ : Seria a bateria?}

$M D$ : Isso, na verdade, a bateria ou um gerador qualquer. Agora, passemos a uma questão mais difícil. Como uma bomba, a bateria produz um tipo de "pressão elétrica". Qual é o nome correto dessa "pressão elétrica"?

$\mathrm{J}$ : Eu aposto que é a voltagem.

$M D$ : e eu aposto que você está certo! Agora sim uma questão complicada. Colocamos um tipo de algodão no filtro do aquário a fim de limpar a água. Isso também tem o efeito de diminuir a quantidade de água que flui através dos tubos num dado intervalo de tempo. Do mesmo modo, num circuito elétrico, o uso de metais maus condutores nos fios podem reduzir o fluxo de eletricidade num dado intervalo de tempo. Num circuito elétrico, como você chama essa propriedade que reduz o fluxo de eletricidade?

J: Resistência!

MD: Correto, John, eu acho que você entendeu. Resumindo, vamos listar no quadro as características do nosso "circuito aquático" que correspondem ao circuito elétrico (Fig. 5.6). Agora, John, com base nessas características, me explique como funciona um circuito elétrico.

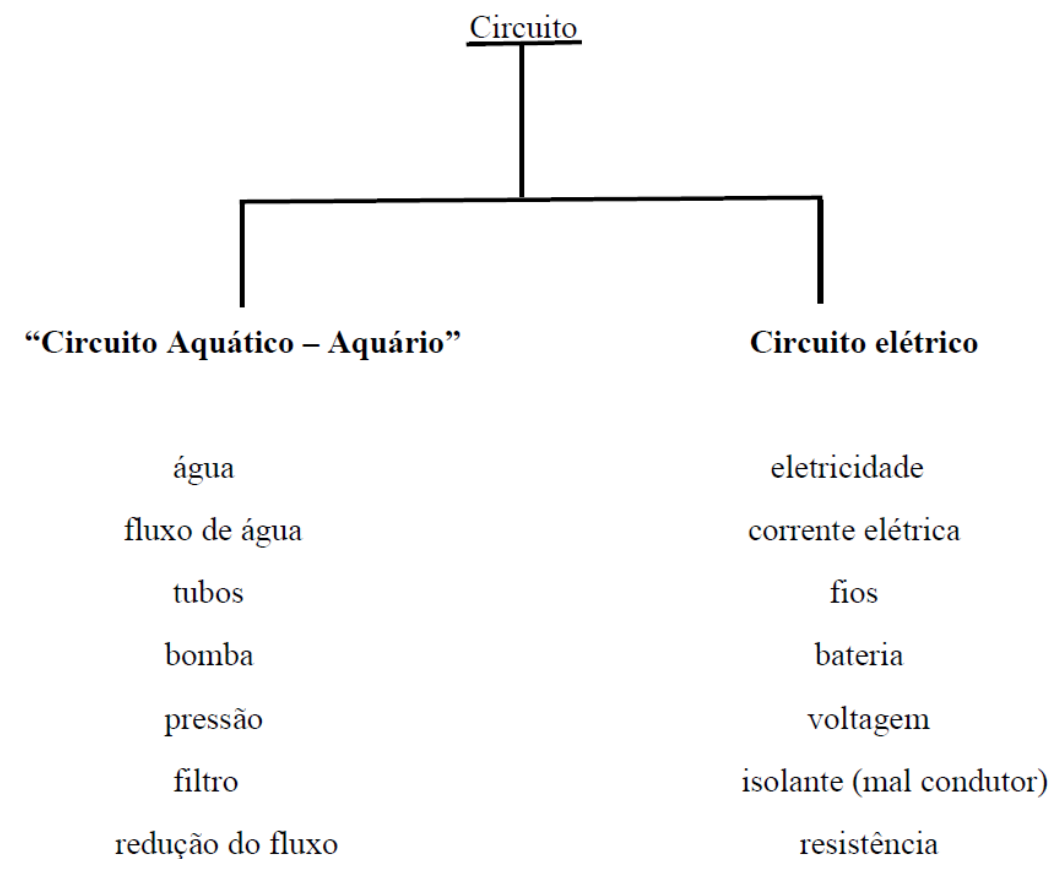

Figura 5.6 - Esquema (1) feito no quadro 
J: Ok, eu vou tentar. Um circuito elétrico é um fio contínuo através do qual a eletricidade pode fluir. Para que haja fluxo de eletricidade, é necessária uma fonte de voltagem, ou seja uma bateria. A quantidade de eletricidade que flui através do circuito num dado intervalo de tempo depende da resistência apresentada no material que constitui o fio. Que tal? Eu acho que consegui entender esse misterioso negócio do circuito elétrico.

$M D$ : Bem impressionante, mas ainda não acabamos. Eu ainda tenho algumas questões complicadas.

$\mathrm{J}$ : Ok, professora, pode mandar.

MD: Olhe o esquema de um circuito elétrico (Fig. 5.7); ele é parecido com o que você tem no seu livro.O circuito possui uma lâmpada e uma bateria carregada. O que aconteceria com o fluxo de eletricidade caso se cortasse o fio e se separassem suas extremidades? Teríamos um resultado diferente, se cortamos o fio antes ou depois da lâmpada?

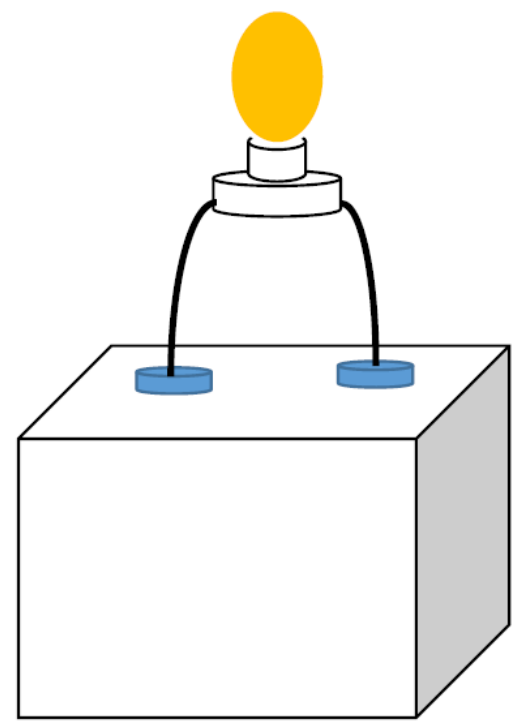

Figura 5.7 - Esquema (2) feito no quadro 
J: Esta é realmente uma questão complicada. Hummm, deixe-me usar a analogia do circuito aquático do aquário. Se eu corto o tubo que leva a água de volta pro aquário, a água continua a fluir, mas provavelmente será derramada no chão. Por outro lado, se eu corto o tubo que conduz a água do aquário justo no nível acima do nível da água, então o fluxo de água é interrompido. Agora eu vou aplicar a analogia ao seu circuito. Se eu corto o fio antes da lâmpada, então a eletricidade deve fluir mas sai do fio. Se eu corto o fio atrás da lâmpada, então a eletricidade para de fluir. Estou certo?

$M D$ : Não, você não está, apesar de seu raciocínio ser muito bom. Quando você corta ou interrompe um circuito elétrico em qualquer ponto do circuito, o fluxo elétrico cessa em todas as partes do circuito. Esta é a função de um interruptor elétrico, a propósito; ele interrompe o circuito, fazendo cessar o fluxo de eletricidade.

J: Mas por que não está certo, professora? Eu usei a analogia.

MD: Porque, John, nenhuma analogia é perfeita. Analogias nos ajudam a compreender certos aspectos de um novo conceito, mas em certo ponto toda analogia não funciona.

J: Se as analogias podem nos conduzir às vezes a conclusões erradas, então eu acho que não deveríamos usá-las.

$M D$ : Mas, John, seria como "jogar fora o bebê junto com água da banheira" se você me permite usar outra "analogia". Analogias podem ser de grande ajuda para mim quando eu explico um novo conceito e para você quando você tenta entendê-lo. O segredo é usar analogias cautelosamente, mantendo sempre em mente suas limitações e as ideias errôneas que surgem quando uma analogia é levada longe demais. Com uso cauteloso, analogias podem muito nos auxiliar, John, assim como elas ajudaram muitos cientistas famosos como você leu no seu livro didático.

J: Que cientistas?

MD: Ah, Astrônomos como Johannes Kepler, que pensou na analogia entre o movimento dos planetas e o funcionamento de um relógio. Cito também Físicos como Joseph Priestley, que sugeriu a lei da força elétrica elaborando uma analogia a partir da lei da força gravitacional.

J: Ah, sim, eu me lembro desses nomes. Eles usaram analogias, ahm?

MD: Com certeza. Analogias são importantes ferramentas do pensamento. Elas podem ajudar a saltar entre velhas ideias que já conhecemos e novas ideias que estamos tentando aprender. 
J: A Ciência é a única área na qual podemos usar analogias?

MD: Você pode usar analogias em todas as áreas, John. Elas são ferramentas com grande potencial na compreensão de conceitos assim como na solução de novos problemas. Mas mantenha em mente suas limitações.

$\mathrm{J}$ : Pode deixar, professora. Muito obrigado. Agora não estou mais preocupado com a prova.

Como se trata de um diálogo fictício não devemos nos ater a suas particularidades. Poderíamos destacar, como exemplo de uma possível mudança de foco, fazer uma análise crítica das respostas bem elaboradas dadas pelo aluno, John. No entanto, o que o autor pretende destacar ao apresentar o referido diálogo, é a postura consciente da professora ao propor uma analogia na tentativa de permitir a seu aluno entender os novos conceitos ligados à eletricidade. Nota-se que Miss Davis usa como análogo algo que ela tem certeza ser do conhecimento do aluno. Afinal o aquário foi construído pelos alunos em sala de aula, como sugere o diálogo. Não se sabe se a atividade de montagem de um aquário foi conduzida de forma a ser usada como análogo na relação futura com circuitos elétricos. No entanto, destacamos que tal postura pode ser presente no planejamento de atividades de professores à medida que os mesmos incorporem reflexões a respeito do uso de analogias. Uma vez que os professores são atentos às possíveis utilizações de determinadas analogias na apresentação de conteúdos específicos, atividades precedentes podem auxiliar na convergência de significados socialmente compartilhados.

Mesmo sem tomar os itens presentes no trabalho de GLYNN (1991) como passos que devem ser necessariamente seguidos, sugerimos que estes sejam levados em consideração. Tal sugestão se deve ao fato de percebê-los em ações conscientes no uso de analogias em atividades didáticas. No exemplo supracitado, conseguimos identificá-los com certa facilidade:

1) Introduzir o assunto alvo: Neste caso o assunto alvo já havia sido apresentado em algum momento em sala de aula. No entanto, este foi recuperado numa situação de preocupação do aluno. Especificamente a proximidade de uma prova sobre $O$ assunto. $O$ assunto-alvo, circuitos elétricos, foi invocado no início do diálogo. (J: Professora, estou 
preocupado com a próxima prova de ciências; $M D$ : Ah, me fale o que está te deixando inseguro?; J: São essas coisas de eletricidade e circuitos elétricos no nosso livro.)

2) Sugerir o análogo : Mediante o pedido de ajuda do aluno, a professora sugere uma analogia na tentativa de elucidar os novos conceitos. (...Talvez uma analogia possa ajudar. Você se lembra quando você e sua turma montaram um aquário na aula?)

3) Identificar as características rel evantes do análogo : Ao trazer à memória do aluno a atividade de montagem de um aquário em sala de aula, a professora destaca os elementos e características relevantes na analogia proposta. ( MD: ... Olhe para o aquário da sala enquanto eu descrevo outra vez como a água flui através dos tubos. Uma corrente é esboçada através de um tubo a partir do aquário por meio de uma bomba que controla a pressão. A água então flui através de um filtro, que reduz o fluxo e retém as impurezas. Finalmente, a água retorna para o aquário através de um tubo. Você lembra e entende, John?)

4) Mapear similaridades entre análogo e alvo: $A$ professora faz isso ao longo do diálogo. No entanto isso fica claro quando ela desenha no quadro um esquema, no qual ficam explicitas as relações de similaridades entre elementos do análogo e do alvo. (MD: ... Resumindo, vamos listar no quadro as características do nosso "circuito aquático" que correspondem ao circuito elétrico (Fig. 1.9). )

5) Estabelecer as diferenças entre os dois domínios: No presente ensaio, a professora demonstra consciência no uso da analogia proposta. Parte dela, a professora, uma pergunta que suscita uma diferença entre os domínios. (MD: Olhe o esquema de um circuito elétrico (Fig. 1.10); ele é parecido com o que você tem no seu livro. $O$ circuito possui uma lâmpada e uma bateria carregada. O que aconteceria com o fluxo de eletricidade se corta o fio e separa suas extremidades? Teríamos um resultado diferente 
se cortamos o fio antes ou depois da lâmpada?) Após a comparação entre os dois domínios feita pelo o aluno, que o levou a interpretações equivocadas a respeito de conceitos relacionados aos circuitos elétricos ( $\mathrm{J}$ : Esta é realmente uma questão complicada. Hummm, deixe-me usar a analogia do circuito aquático do aquário. Se eu corto o tubo que leva a água de volta pro aquário, a água continua a fluir, mas provavelmente será derramada no chão. Por outro lado, se eu corto o tubo que conduz a água do aquário justo no nível acima do nível da água, então o fluxo de água é interrompido. Agora eu vou aplicar a analogia ao seu circuito. Se eu corto o fio antes da lâmpada, então a eletricidade deve fluir mas sai do fio. Se eu corto o fio atrás da lâmpada, então a eletricidade para de fluir. Estou certo?), a professora destaca diferenças entre os domínios. (MD: Não, você não está, apesar de seu raciocínio ser muito bom. Quando você corta ou interrompe um circuito elétrico em qualquer ponto do circuito, $o$ fluxo elétrico cessa em todas as partes do circuito. Esta é a função de um interruptor elétrico, a propósito; ele interrompe o circuito, fazendo cessar o fluxo de eletricidade.)

6) Esboçar conclusões: No caso apresentado, a professora esboça conclusões de ordem geral. Ela tenta discutir com o aluno que, apesar das diferenças existentes entre os dois domínios, o uso de analogias a fim de apresentar novos conceitos se apresenta como uma ferramenta de grande potencial. No entanto, é necessária a vigilância e 0 destaque às diferenças entre os domínios apresentados, a fim de que concepções indesejadas sejam evitadas. (MD: ...Analogias são importantes ferramentas do pensamento. Elas podem ajudar a saltar entre velhas ideias que já conhecemos e novas ideias que estamos tentando aprender. Você pode usar analogias em todas as áreas, John. Elas são ferramentas com grande potencial na compreensão de conceitos assim como na solução de novos problemas. Mas mantenha em mente suas limitações.).

\subsubsection{Uso de analogias como elemento na formação de professores}

Como já vimos, o TWA model se apresenta como uma forma de sistematização do uso de analogias em aulas de ciências. Este modelo sugere, por meio de seus seis passos, um processo progressivo e temporal no uso dessa 
"ferramenta didática". Como também destacamos anteriormente, tais orientações não são restritas aos professores, mas antes são aplicáveis também aos autores de analogias presentes nos livros didáticos.

No entanto, apesar de destacarmos que tais orientações vão ao encontro da preocupação em tornar as ações dos professores, relacionadas às atividades de uso de analogias, mais conscientes, reduzindo o grau de alienação dos sujeitos envolvidos na atividade, julgamos pertinente destacar que tais reflexões não devem ser restritas ao momento da elaboração ou da utilização das analogias. Neste tópico, vamos insistir na proposta de incorporar o tema "o uso de analogias em atividades didáticas" na formação inicial e continuada dos professores.

Inicialmente, a fim de explicitar a presente perspectiva, apresentamos o trabalho de VENVILLE (2008), no qual o professor é visto como "elemento" fundamental no desenvolvimento e avaliação de um método efetivo do uso de analogias. Nosso apelo à incorporação do tema como elemento presente nos cursos de formação de professores é reforçado pela perspectiva assumida na qual se entende que analogias participam efetivamente do nosso processo cognitivo. Esta perspectiva será detalhadamente explicada no capítulo 2 da presente tese.

\subsubsection{Focus-Action-Reflection (FAR) Guide: (Foco-Ação-Reflexão) - Um Guia para o uso de analogias em aulas de Ciências}

Ainda na perspectiva de incorporar discussões a respeito do uso de analogias nas aulas de ciências, e baseados nos trabalhos publicados na área de Ensino de Física, apresentamos o FAR guide que, de forma similar a outros artigos afins, sugere uma metodologia voltada ao uso de analogias em atividades didáticas.

No trabalho de Venville (ibid), os professores foram envolvidos no desenvolvimento do modelo proposto por ela. A professora australiana explica que sua pesquisa foi baseada em observações de práticas de professores que datam de no mínimo 10 anos.

A primeira fase da pesquisa contou com um levantamento minucioso da literatura especializada, a fim de identificar possíveis modelos que apontassem 
sistematizações quanto ao uso de analogias em sala de aula. Os modelos foram julgados quanto à sua eficácia na prática dos professores participantes da pesquisa. A eficácia dos modelos foi avaliada a partir de observações de sua aplicação em sala de aula, assim como foi também baseada em dados tomados em entrevistas com os professores e com alunos após as aulas. As observações dos professores, assim como a compreensão dos alunos a respeito dos conceitos abordados, foram avaliados. Apesar de não explicitar em seu artigo, por se tratar de uma pesquisa a posteriori do TWA model, avaliamos que este modelo esteve sob o seu escrutínio.

Segundo a autora, a pesquisa visava desenvolver um modelo que levasse os professores a pensar no uso de analogias antes, durante e após as aulas. Nesse sentido, aspectos como Foco, Ação e Reflexão foram as bases para o desenvolvimento de um guia de uso de analogias em atividades didáticas que acaba recebendo o nome dos referidos aspectos (FAR guide for teaching with analogies).

Professores foram envolvidos não apenas na avaliação de modelos já existentes, antes eles foram considerados e ouvidos em todo o processo do modelo, a saber, no desenvolvimento e na avaliação do mesmo. O FAR guide foi apresentado em diversos workshops em escolas locais, em congressos nacionais e internacionais. Além de apresentar o modelo, o que se pretendeu foi a avaliação do mesmo feita por diferentes professores. A seguir, na tentativa de elucidar o presente modelo, apresentaremos um exemplo prático na tentativa de mostrar seu processo cíclico de avaliação e validação.

Este modelo vem ao encontro de nossa preocupação quanto ao uso de analogias em aulas de ciências e destaca a participação dos professores não somente na atividade do uso da analogia, mas sobretudo o coloca como agente e autor dessa complexa atividade. Consideramos que a principal colaboração do presente artigo é a de apelar para a inclusão de reflexões a respeito do uso de analogias em sala de aula, na formação inicial e continuada dos professores. 


\subsection{Foco, Ação e Reflexão}

Como destaca a autora, o FAR guide se apresenta como uma proposta que visa contribuir com os professores na tentativa de maximizar os benefícios e minimizar os problemas que podem surgir no uso de analogias. A fim de melhor compreender cada fase do presente método, propomos a seguir detalhá-lo:

a. Foco - este passo pode ser identificado como similar aos passos inicias do TWA model. No entanto, identificamos o foco como um processo mais amplo que sugere ao professor colocar em questão o uso de analogias como processo de aproximação entre dois "objetos" ou conceitos. O professor parte das dificuldades encontradas pelos alunos e professores, referentes ao conceito em questão. Usando sempre a mesma nomenclatura (análogo e alvo), nesta fase o professor identifica as dificuldades e características do conceito (alvo), reflete quanto ao seu grau de abstração, decide o(s) análogos com possíveis potenciais de contribuições, e os avalia quanto à familiaridade dos estudantes.

Vale ressaltar que questões relativas ao "geral" e ao particular ganham espaço nesta fase do processo. Como salientamos anteriormente, o presente método teve como base professores em suas práticas reais e levou em consideração observações dessas práticas, assim como o relato dos agentes envolvidos nas atividades, os alunos e professores. Por isso, mesmo destacando os cuidados ao tentar fazer, em qualquer grau, generalizações, visto que cada atividade é única devido aos diferentes contexto, as diferentes ferramentas e aos diferentes sujeitos nela envolvidos, é possível identificar similaridades no conjunto de experiências particulares que servem de base para pensarmos nossas ações especificas.

No que tange à escolha de análogos, o quesito "ser familiar" parecenos bastante subjetivo. Visto que a experiência de cada indivíduo, presente em sua história, carrega consigo o complexo processo de formação de significados, e dada nossa condição limitada, nunca 
temos acesso a esse processo em toda sua integralidade. No entanto, há questões relativas à cultura, ao tempo histórico, às formas de produção e à linguagem que podem apresentar elementos de significação compartilhados. A partir dessa perspectiva, reforçamos a importância de experiências acumuladas nos presente campo como elementos essências à contribuição de práticas particulares de professores.

b. Ação - Apesar de sermos levados a pensar que, na etapa descrita anteriormente, o Foco, todo trabalho se concentra no planejamento das atividades, ou seja, sempre antecede a ação didática, é possível que este se estenda aos momentos iniciais da aula. Isso vai depender das circunstâncias, no entanto isso não dispensa 0 trabalho de planejamento na etapa do focos. Ao contrário, tal atividade prévia nos parece essencial, sem a qual voltamos ao uso improvisado.

A etapa denominada como ação parece estar relacionada ao período no qual as analogias são usadas com o fim didático. Esta etapa depende diretamente da etapa precedente, mas não se reduz a mesma. Nela acontecem as negociações dos significados que serão compartilhados com os alunos. Aqui é sugerida a construção de relações explícitas, entre as características do análogo e as características do alvo. Nesta etapa também devem ser explicitadas as diferenças entre $o$ alvo e $o$ análogo, destacando as aproximações de formas ou conceituais que são indesejadas. Neste momento o professor deve deixar claro que o análogo não deve ser entendido como substituição do alvo. Mostra-se "onde" a analogia deixa de funcionar.

c. Reflexão - De forma similar à primeira, na etapa da Reflexão parece haver uma sugestão de que esta acontece num momento bem estabelecido no processo do método sugerido, neste caso subsequente à etapa da Ação. No entanto, esta etapa que destaca fundamentalmente as conclusões e aponta para futuras correções, 
tem espaço durante atividade. No momento da utilização de certa analogia, o professor pode se dar conta, na interação particular com aquele grupo, que algumas modificações devem ser encaminhadas. Existem questões que serão evidenciadas durante a aula, e estas devem ser registradas durante a atividade, enquanto outras surgirão como resultado de reflexões provenientes de seus apontamentos pósatividade.

As três etapas do FAR guide têm por objetivo orientar as atividades de uso de analogias. Este método se apresenta como uma alternativa de sistematização no uso de analogias em aulas de ciências. O esquema da figura abaixo representa uma síntese das três etapas:

Quadro 5.2 - Síntese das etapas do FAR guide

\section{Foco}

Conceito

... é difícil, não familiar ou abstrato?

Alunos Quais são as concepções dos alunos a respeito do conceito apresentado?

Análogo

Qual é o grau de familiaridade dos alunos com o(s) análogo(s) que serão utilizados?

\section{Ação}

Resultado desejado

Discussão das características do análogo e do conceito científico. Estabelecer possíveis relações entre eles.

Resultado indesejado Apresentação e discussão a respeito das relações indesejadas entre análogo e alvo. 


\section{Reflexão}

Conclusões

A analogia utilizada foi clara e útil, ou foi confusa? $A$ atividade analógica permitiu alcançar os resultados esperados?

Modificações e melhorias

A partir das reflexões e dos resultados identificamos mudanças e melhorias que devem ser feitas antes da próxima utilização?

No item anterior, usamos como exemplo um diálogo fictício entre uma professora de ciências e um aluno. O aluno apresentava dificuldades em compreender conceitos relacionados a um circuito elétrico simples de corrente contínua. O menino solicitou ajuda da professora, que utilizou a analogia do funcionamento de um aquário construído pelos alunos seguindo os passos do TWA model. A fim de mostrar como a estrutura metodológica do FAR guide se manifesta numa atividade prática, utilizamos um exemplo contido no livro "Using Analogies in Middle and Secondary Science Classrooms", no qual a analogia de um trem hipotético foi utilizada como recurso na tentativa de tornar compreensíveis os conceitos relacionados ao mesmo tema, a saber, circuitos elétricos simples.

A ideia de que a corrente elétrica diminui à medida que ela atravessa o circuito, e com isso chega menor ao retornar à bateria, é uma concepção muito comum por parte dos alunos. Tasker \& Osborne (1985) afirmam ter encontrado um percentual de cerca $40 \%$ dentre alunos de 10 a 16 anos de idade com essa concepção. Na tentativa de superar esta ideia equivocada relacionada ao conceito de corrente elétrica em circuitos simples, propõe-se o uso da analogia supracitada.

Reproduzimos mais uma vez a Figura 5.2, pois esta retrata o análogo utilizado na análise em questão. A figura foi reapresentada aqui para recuperar visualmente, de forma prática ao leitor, e a fim de facilitar a leitura do quadro exposto a seguir. 


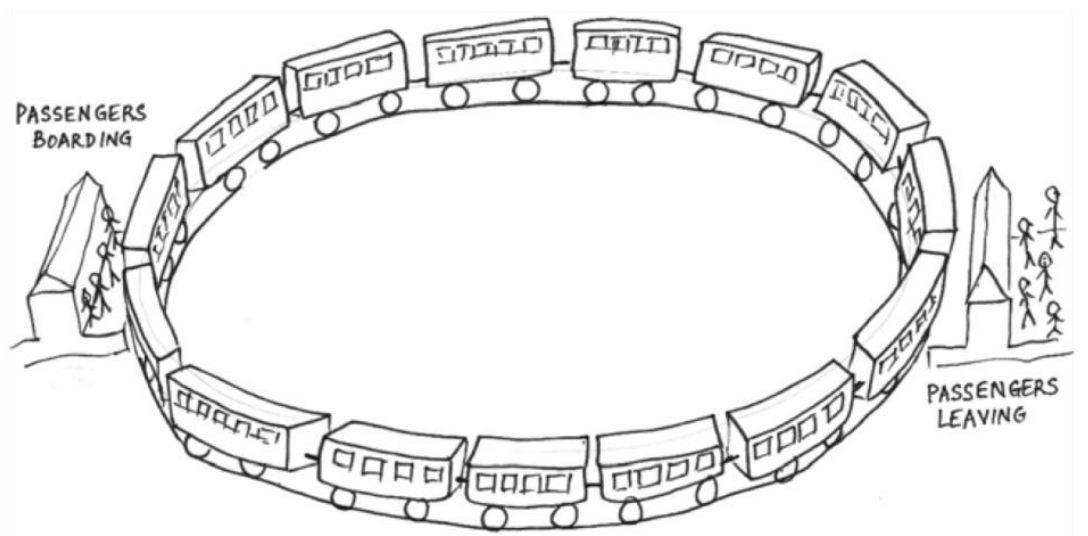

Figura 5.2 - Analogia do trem contínuo

Quadro 5.3 - Quadro análogo x alvo (analogia do trem contínuo)

\begin{tabular}{|c|c|c|c|c|}
\hline $\begin{array}{c}\text { Grandezas } \\
\text { e/ou }\end{array}$ & $\begin{array}{c}\text { Corrente } \\
\text { elétrica }\end{array}$ & Energia elétrica & Gerador (Pilha & Lâmpada \\
elementos de & & & & \\
um circuito & & & & \\
simples & & & & \\
\hline Analogia do & Vagões do trem & Pessoas que & Estação onde & Estação onde \\
\hline Trem contínuo & & embarcam no & as pessoas & as pessoas \\
\hline
\end{tabular}

Uma vez estruturada a prévia simplificada das possíveis relações entre análogos e alvos, vamos apresentar um ensaio do $\boldsymbol{F A R}$ guide, também em formato de quadro, aplicado aos conceitos envolvidos num circuito elétrico simples. 
Quadro 5.4 - Etapa Foco (analogia do trem contínuo)

\section{A analogia do trem contínuo aplicada à conservação da corrente elétrica num}

\section{circuito simples em série.}

\begin{tabular}{|c|c|c|}
\hline \multirow{3}{*}{ Foco } & Conceito & $\begin{array}{l}\text { Só há corrente elétrica em circuitos } \\
\text { elétricos fechados. A energia elétrica } \\
\text { num circuito é consumida (mais } \\
\text { precisamente convertida em outra } \\
\text { forma de energia), mas a corrente } \\
\text { elétrica é conservada. É preciso } \\
\text { lembrar que o conceito de energia } \\
\text { não é trivial. Não é evidente que este } \\
\text { conceito seja facilmente } \\
\text { compreendido no modelo. }\end{array}$ \\
\hline & Alunos & $\begin{array}{l}\text { Alunos acreditam que a corrente } \\
\text { elétrica é consumida ao longo do } \\
\text { circuito. Para muitos isso se justifica } \\
\text { na medida em que percebemos que } \\
\text { as pilhas têm um tempo útil limitado e } \\
\text { que as lanternas brilham menos com } \\
\text { o tempo. } \\
\text { Alguns alunos acreditam que a } \\
\text { corrente elétrica sai da bateria, passa } \\
\text { pela lâmpada e o excedente volta à } \\
\text { bateria. } \\
\text { Trens de brinquedo são geralmente } \\
\text { conhecido pelas crianças. }\end{array}$ \\
\hline & Análogo & $\begin{array}{l}\text { Um trem contínuo transporta pessoas } \\
\text { (energia) de uma estação a outra. As } \\
\text { pessoas embarcam e desembarcam } \\
\text { do trem, mas o trem é o mesmo (não } \\
\text { é "consumido"). }\end{array}$ \\
\hline
\end{tabular}


Quadro 5.5 - Etapa Ação (analogia do trem contínuo)

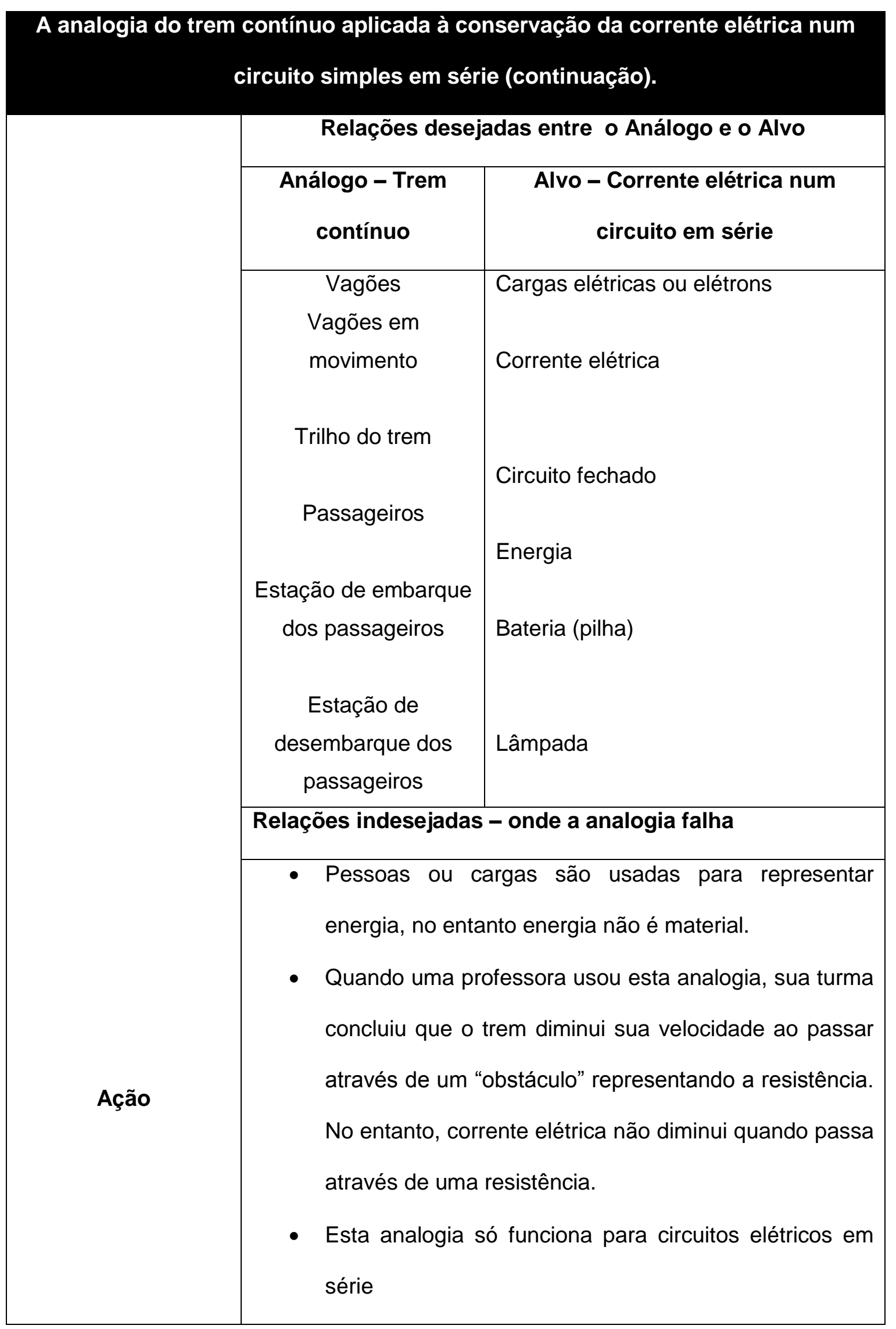


Quadro 5.6 - Etapa Reflexão (analogia do trem contínuo)

\begin{tabular}{l} 
A analogia do trem contínuo aplicada à conservação da corrente elétrica num \\
circuito simples em série (continuação). \\
\begin{tabular}{|l|l|l|}
\hline \multirow{2}{*}{ Reflexão } & Conclusão & $\begin{array}{l}\text { Minha análise das relações } \\
\text { desejadas entre Análogo e Alvo } \\
\text { foram apropriadas e coerentes? } \\
\text { Devo retomar a mesma analogia } \\
\text { ou devo reelaborá-la a fim de } \\
\end{array}$ \\
\cline { 2 - 3 } & Modificações e melhorias & Tendo detectado problemas no \\
& uso da analogia do trem contínuo, \\
& eu poderia utilizar outras analogias \\
& complementares?
\end{tabular} \\
\hline
\end{tabular}

Nosso objetivo, ao apresentar o exemplo esquematizado acima, é mostrar que, apesar das diferenças e especificidade de cada ação didática, existem elementos que podem se aproximar de outras práticas, em outros contextos. $\mathrm{Na}$ verdade, queremos apontar que elementos de atividades de certos contextos particulares podem ser compartilhados, ou ao menos podem servir como referência, ao pensarmos em atividades didáticas com o uso de analogias. Mesmo que sejam, e geralmente serão, necessárias adaptações dos análogos em função da familiaridade dos alunos, aspectos como relações desejadas e relações indesejadas apontadas em exemplos anteriores servem de reflexões a priori. Ter uma espécie de "lista" de relações indesejadas em experiências anteriores dá ao professor a vantagem de conhecer possíveis caminhos que devem ser evitados, ou mesmo trazer à discussão com os alunos na tentativa de mostrá-los em que aspectos a analogia falha. Destacamos também, como aspecto positivo da presente metodologia, a possibilidade de tornar explícita a função de uma analogia. Quando apontamos aqui a função das analogias, estamos nos referindo sempre às atividades de ensino. 


\subsection{Alguma considerações.}

Neste capítulo tentamos dar um panorama geral a respeito do tema "O USO DE ANALOGIAS NAS AULAS DE CIÊNCIAS". Aqui propomos levantar inicialmente, segundo alguns autores, a diferença entre analogia e metáfora. Nosso intuito aqui não foi esgotar as discussões a respeito da estrutura de cada uma delas assim como dos elementos que as distinguem. Antes, desejamos apontar que em alguns trabalhos ambas são tratadas como elementos com potencial de estabelecer vínculos entre 0 que é familiar com o que é desconhecido e, assim, contribuir com a aprendizagem ${ }^{48}$ de novos conceitos. Em nossa pesquisa não fizemos uma distinção rigorosa entre os dois conceitos apresentados, mas antes lançamos mão da análise de ambos, no sentido de olhar para nosso problema de pesquisa, o uso de representações no ensino de Física Quântica. No entanto, destacamos que, dentre o universo das representações, nosso foco está no uso das analogias nas ações didáticas.

Um levantamento prévio de trabalhos que lançam mão do uso de analogias em aulas de ciências associado às reflexões presentes na introdução reforça a pertinência do tema, assim como traz elementos relevantes à nossa pesquisa. $O$ trabalho de Curtis e Reigeluth (1984) permitiu-nos levantar um conjunto de seis categorias, combinadas com 18 subcategorias, de analogias presentes na apresentação de conceitos de Ciências. Tal levantamento se prestará, ainda que dentro de uma transposição de contexto ${ }^{49}$, como possível elemento metodológico. A descrição metodológica será melhor apresentada no capítulo 6 .

Retomamos aqui o destaque dado à importância de pesquisas que se orientem a partir da prática de professores. Reconhecidas as particularidades contextuais, julgamos positivas iniciativas que buscam a construção de um repertório de analogias com os respectivos resultados, tanto de potencialidades quanto de dificuldades encontradas. Este repertório já existe em certo grau, como o apontado em Harrison e Coll (2008) e pode servir de base para professores que pretendem

\footnotetext{
${ }^{48} \mathrm{O}$ foco da presente pesquisa é no ensino, tendo em vista que nossa maior contribuição visa à formação do professor. No entanto, as ações didáticas aqui investigadas não têm outro objetivo senão a aprendizagem dos alunos. Por isso, ainda que nosso enfoque seja dado no uso de analogias em atividades de ensino, e que a ação do professor se constitua o nosso objeto empírico de investigação, a aprendizagem aparece diversas vezes em nossa análise e, fundamentalmente, em nossos referenciais teóricos.

${ }^{49}$ Termo utilizado aqui para apontar que as categorias aqui apresentadas foram criadas a partir da análise de analogias presentes em livros didáticos. Nossa pesquisa pretende olhar, segundo essas categorias, para as analogias utilizadas pelos professores em sua atividade docente em sala de aula.
} 
lançar mão do uso de analogias em suas aulas de ciências de forma sistemática. No entanto, os autores reuniram trabalhos ligados à prática de professores australianos. É, então, provável que os análogos usados, as analogias a estes vinculadas, as potencialidades e as falhas tenham um "status" de significação que difere em contextos semelhantes aos nossos. É por isso que endossamos a importância da incorporação dessas reflexões na formação inicial e continuada de nossos professores.

O FAR guide foi apresentado como uma metodologia de grande potencial na formação inicial e continuada de professores. Atividade vinculadas ao uso de analogias em aulas de ciências podem estar apoiadas nas reflexões apontadas pela presente metodologia. No entanto, destacamos que este guia carece de uma reflexão teórica que traga elementos que estejam além das impressões imediatas tiradas da observação. O FAR guide apresenta suas três etapas sem incluir em suas considerações de que forma cada uma delas contribui para o aprendizado dos conceitos de ciências por ela sugeridos, falta-lhe a concepção de aprendizagem adotada.

Gostaríamos de apresentar um ensaio com as experiências provenientes do rico trabalho de Venville (2008). No entanto, nossa decisão de não fazê-lo é baseada fundamentalmente em dois motivos, a saber, primeiramente por se tratar de um trabalho que desviaria o foco da presente tese, e em segundo lugar dada sua impossibilidade, visto que não dispomos de elementos essenciais como as regras, características detalhadas das comunidades envolvidas e os critérios estabelecidos na divisão social do trabalho.

Os desdobramentos das discussões aqui levantadas reaparecem nas perspectivas futuras provenientes da presente pesquisa. 
CAPÍTULO 6 


\section{METODOLOGIA}

(...) O cientista não estuda a natureza porque ela é útil; ele a estuda porque encontra nela prazer, e ele sente prazer porque ela é bela (...) Não falo aqui, evidentemente, desta beleza que atinge os sentidos, da beleza de qualidades e de aparência; não que eu a despreze, longe disso, mas ela não tem nada a ver com a ciência; eu quero falar dessa beleza mais íntima que vem da ordem harmoniosa das partes, e que uma inteligência pura pode aceder."

“(...) É então a busca dessa beleza especial, o senso de harmonia do mundo, que nos faz escolher os fatos mais claros a contribuir com esta harmonia, a mesma que o artista escolhe, dentre os traços de seu modelo, esses que completam o retrato o concede o caráter, a vida. "(Poincaré, 2012, p.4) 
Neste capítulo pretendemos apresentar a metodologia que usaremos na análise empírica de episódios selecionados de aulas do Ensino Médio. Recorremos às reflexões teóricas levantadas nos capítulos anteriores, a partir das quais fundamentamos tanto nossa unidade de análise quanto as categorias.

De nossa apresentação metodológica, destacaremos inicialmente as características da pesquisa realizada, em seguida, apontaremos as características do contexto empírico e, finalmente, apresentamos a estrutura e nossa unidade de análise. De posse dessa estrutura, pretendemos avaliar os episódios selecionados a partir do registro em vídeo de aulas de física - temas relacionados à física quântica em escolas do ensino médio.

\subsection{Características da pesquisa realizada}

Como método de pesquisa, foi utilizada a pesquisa qualitativa, uma vez que nossa base de dados é construída a partir das interpretações de falas, gestos e demais ações dos professores em sala de aula. Lüdke e André (1986) destacam cinco características básicas ao apresentarem abordagens qualitativas:

1. A pesquisa qualitativa tem o ambiente natural como sua fonte direta de dados e o pesquisador como seu principal instrumento; 2. Os dados coletados são predominantemente descritivos; 3 . A preocupação com o processo é muito maior do que com o produto; 4. O "significado" que as pessoas dão às coisas e à sua vida são focos de atenção especial pelo pesquisador; 5 . A análise dos dados tende a seguir um processo indutivo. (p.11-13)

Nosso ensaio empírico se enquadra na maioria dos itens supracitados. No entanto, como destaca Carvalho (2006), apontamos para a própria câmera de vídeo como elemento que compartilha com o pesquisador o papel de principal instrumento. É a partir da coleta de imagens pela câmera que pautaremos nossa análise. Ademais, olhamos com ressalva o processo indutivo destacado no último item, afinal, o propósito de nosso ensaio não é fazer generalizações, mas antes olhar, no contexto empírico delimitado, como professores podem lançar mão do uso de 
analogias como ferramenta didática em sua prática de sala de aula, fundamentalmente, como o fazem quando o tema das aulas está ligado ao domínio da física quântica. Ainda assim, reconhecemos que o presente estudo de caso tem também por objetivo pensar em ações em diferentes contextos, o que daria a este processo certo grau indutivo.

Nossa reflexão teórica nos permite um olhar particular, a partir do qual organizamos nossos dados. Como afirma Gonçalves (1997) são "as hipóteses pensadas e estruturadas anteriormente que orientam o nosso olhar sobre o objeto investigado. Nossos conhecimentos prévios, nossos referenciais teóricos e, principalmente, nossa visão de mundo, definem o que queremos ou podemos observar" (p.107). Partimos, portanto, das três dimensões, a partir das quais olhamos as analogias: como ferramenta didática; como componente do par dialético analogia-categorização (elemento fundamental na estrutura cognitiva do indivíduo); como instrumento de generalização na construção do conhecimento científico. Como o interesse da pesquisa está centrado no uso de analogias como "ferramenta de comunicação" de conceitos relacionados à física quântica, as escolhas dos episódios que serão analisados "emergem" do discurso, do enunciado, das falas dos professores. Por isso, nosso olhar é focalizado no professor, sobretudo no que ele fala, mas também em possíveis representações pictóricas, gráficas ou algébricas.

\subsection{Contexto empírico}

Os dados que construímos e discutimos aqui relacionam-se a videogravações de aulas de física cujos temas pertencem ao domínio da física quântica. As referidas aulas foram ministradas por professores que, outrora, participaram de cursos de formação continuada realizada na Faculdade de Educação da Universidade de São Paulo (FEUSP), em parceria com a Secretaria de Educação do Estado de São Paulo. Os cursos oferecidos pela FEUSP foram realizados em duas etapas, a saber, a primeira consistia na construção em conjunto ${ }^{50}$ de sequências didáticas voltadas a temas da física moderna e contemporânea (relatividade restrita, física quântica e

\footnotetext{
${ }^{50}$ Conjunto este constituído por professores e pesquisadores da Universidade de São Paulo, alunos do programa de pós-graduação em educação e em ensino de ciências, e professores da rede estadual de educação de São Paulo.
} 
física de partículas), e a segunda etapa estava relacionada à aplicação das sequências nas respectivas turmas.

O fato de compartilharmos interesse de pesquisa com os colegas de grupo, coordenado pelo professor Elio Ricardo, bem como pontos de vista teóricos e metodológicos com relação à ação do professor, nos permitiu compartilhar as aulas videografadas, dentre as quais algumas estão presentes na tese de Shinomiya (2013). Destacamos que tais perspectivas comuns, que apontavam como foco a ação do professor, podem ser evidenciadas pelo direcionamento da câmera. $\mathrm{Na}$ verdade, por se tratar de registros de vídeo com potencialidade de uso em diferentes pesquisas, mas que tinham em comum ou a ação dos professores, ou as relações discursivas entre os alunos, a maioria das aulas foram filmadas com duas câmeras, das quais uma tinha como foco o professor e a outra focalizava ora o conjunto total dos alunos, ora grupos específicos, de acordo com as atividades desenvolvidas.

Como base de tomada de nossos dados, lançamos mão, inicialmente, do conjunto de aulas videografadas cujo foco era o professor. Na verdade, contamos com um conjunto de aulas das quais algumas foram registradas por colegas da referida equipe de pesquisa da USP, enquanto outras só foram possíveis devido ao engajamento dos próprios professores, que se comprometeram em realizar as filmagens de suas próprias aulas e compartilhá-las com o nosso grupo de pesquisa.

Dado que buscamos investigar a ação de professores em sua prática didática, mas sobretudo em aulas sobre temas relacionados à física quântica, a escolha dos professores participantes da pesquisa se deu basicamente sob dois critérios: o primeiro ligado à oportunidade, afinal, como indicamos anteriormente, estes pertenciam ao grupo de docentes participantes de cursos de formação continuada oferecidos pala FEUSP e tinham contato direto com nosso grupo de pesquisa; já o segundo critério diz respeito aos temas trabalhados nas aulas. Uma vez que nossa investigação busca olhar o uso de analogias em aulas de física quântica, nos restringimos a aulas de professores ligadas ao tema.

Para a realização de nosso ensaio empírico, lançamos mão de um conjunto de oito aulas (Apêndice A) de quatro professores. Os docentes participantes de nossa pesquisa são licenciados em física e lecionam em escolas da rede pública estadual de São Paulo, assim como na rede privada. Dois dentre eles, na época da gravação 
de suas aulas, eram alunos do programa de pós-graduação Interunidades em Ensino de Ciências da Universidade de São Paulo, tendo assim o perfil de professor pesquisador.

Os dados referem-se ao conjunto de aulas cujos temas estavam ligado à física quântica. Mais especificamente, para a avaliação do ensaio empírico, nossos dados foram construídos a partir das aulas sobre Modelos Atômicos; Efeito Fotoelétrico; e sobre a Natureza da Luz (a partir do interferômetro de Mach-Zehnder). As referidas aulas forma ministradas durante os anos de 2011 e 2012.

\subsection{Estrutura e unidade de análise}

Destacamos aqui que se exige do pesquisador um cauteloso trabalho metodológico para transformar as aulas videografadas em dados. Como ressalta Carvalho (2006), "temos que ter consciência de que as gravações não são os dados de uma pesquisa, muito pelo contrário, como a aula é um fenômeno bastante complexo, uma mesma gravação, pode servir para estudar mais de um problema tendo por base mais de um referencial teórico" (p.32).

Buscamos em nossa análise teórica entender as analogias nas três dimensões aqui apresentadas. Tal análise visa superar a contradição inicial no uso de analogias em atividades didáticas voltadas a temas de física quântica, uma vez que, se entendemos (de forma simplificada) que as analogias relacionam o "novo" a conceitos pertencentes ao repertório da estrutura cognitiva do sujeito, e se partimos da concepção de que os conceitos da física quântica não possuem relação com a realidade sensível imediata, a referida contradição está constituída. Esta, então, nos parece apontar uma impossibilidade, ou ao menos sugerir que o uso de analogias é inadequado a atividades didáticas voltadas ao referido domínio da física.

As dimensões aqui analisadas surgem exatamente das relações presentes nas especificidades da atividade em questão. Primeiramente, trata-se de uma atividade de ensino, que busca compartilhar conceitos com os alunos, logo julgamos pertinente entender o papel das analogias na formação de conceitos na estrutura cognitiva do sujeito. É então a partir dessa perspectiva que o par dialético analogiacategorização tem um papel fundamental na concepção de analogia aqui adotada. Em seguida, como se trata de uma área específica do conhecimento - a ciência - e 
sobretudo, como se trata de um domínio particular da ciência - a física quântica -, buscamos na epistemologia da ciência entender qual é o papel das analogias na elaboração do conhecimento científico. Por último, a analogia como ferramenta didática deve ser entendida como qualquer atividade de ensino e com isso deve estar presente nos diversos momentos relativos a uma ação didática, a saber, no planejamento da atividade, na aplicação da atividade e na avaliação. De fato, as analogias devem ser entendidas e "praticadas" como uma ferramenta didática de grande potencial, mas, para que as tenhamos como tal, é necessário incorporá-las de forma sistemática às ações conscientes do professor, e não apenas como "recurso linguístico esporádico que surge apenas no momento da ação do professor em sala de aula. "Se analogias devem ser utilizadas de forma eficaz pelos professores de ciências, uma estratégia cuidadosamente planejada é necessária, esta destinada a fazer as analogias relevantes para o maior número de alunos possíveis".(VENVILLE, 2008, p.24)

Destacamos que as diferentes perspectivas teóricas não se constituem apenas como uma ferramenta de análise dos dados empíricos, antes porém a estrutura analítica emerge dos episódios. Na verdade, é na leitura metodológica que a síntese proposta é possível. Por isso, apesar de chamarmos a pesquisa empírica de ensaio experimental, este se constitui elemento fundamental na elaboração da unidade de análise, assim como no reforço da síntese teórica. De fato, a perspectiva de nossa pesquisa teórica parte sempre de ações reais do homem no mundo, da mesma forma, como apontamos anteriormente, que os conceitos surgem na história do sujeito devido à ação constante do par dialético analogia-categorização, e esta é proveniente de sua ação no mundo. A presente perspectiva enfoca "os indivíduos reais, a sua ação e as suas condições materiais de vida , tanto as que encontraram, como as que produziram pela sua própria ação" ( ENGELS e MARX, 2007 [1845], p. 17). Desta forma, destacamos que as características da pesquisa teórica influenciam e são influenciadas no, e pelo, olhar de nosso ensaio.

\subsubsection{A estrutura de análise}

A partir da síntese das três dimensões de uso das analogias, elaboramos uma estrutura de análise que será usada em nosso ensaio empírico. Como resultado, 
organizamos a análise dos dados em três grupos de categorias, a saber, o nível da analogia; seu formato de apresentação; e a indicação de ações prévias. Na verdade, cada grupo de categorias representa um "momento" da ação analógica de acordo com a perspectiva adotada. Uma vez que a referida ação está inserida no conjunto de ações didáticas, esta busca, no mecanismo cognitivo do par dialético analogiacategorização, permitir os movimentos ascendente e descendente característicos da estruturação dos conceitos. Tais movimentos geram ao mesmo tempo os processos de objetivação e generalização dos conceitos, como discutimos no capítulo 2.

\subsubsection{Níveis de analogias usadas em atividades didáticas no ensino de física}

A escolha dos níveis de classificação das analogias tem origem nas categorias presentes nas obras de Poincaré. Sobretudo, é o conceito de analogia matemática na perspectiva do filósofo e matemático francês que nos permitiu criar a "nova" categoria, também nomeada de "analogia matemática", com o olhar voltado para ações didáticas, especificamente em aulas de física quântica.

Apesar de encontrarmos no trabalho de Curtis e Reigeluth (1984), assim como em outros trabalhos neste inspirado [GLYNN et al. (1994); VENVILLE (2008)], categorias que classificam os análogos quanto à sua natureza (concreta ou abstrata), ao seu domínio (pertencente ou não ao domínio da física) e ao nível de relação (estrutural ou funcional), apontamos para o caráter inovador das categorias elaboradas na presente tese. Primeiramente, destacamos que, enquanto as categorias elaboradas por Curtis e Reigeluth (idem) são destinadas a analogias presentes em livros didáticos de ciências, nossas categorias tratam das analogias presentes nas ações didáticas dos professores. Desta forma, ao invés de considerarmos separadamente os elementos que constituem a analogia proposta e o momento de seu uso, nossa perspectiva olha para a atividade analógica. Por isso os níveis das analogias são os mesmo tempo sintéticos e abrangentes. Neles identificamos as características que são relevantes na ação didática, assim como agregamos ao conjunto as "analogias matemáticas", que em nossa análise se constituem fundamentais e adequadas à construção dos conceitos do domínio da física quântica. 
Como resultado da síntese fundamentalmente entre as dimensões didática e epistemológica, apresentamos no Quadro 6.1 nossa interpretação das características de cada nível de analogia presente (ou com potencialidade de estar presente) em ações didáticas inseridas no contexto do ensino de física quântica.

Quadro 6.1- Características que orientam a análise metodológica da categoria "nível"

\section{Nível da Analogia}

Figurativa

Mecânica

Matemática
Analogias que apresentam semelhanças de forma. Nesse nível as semelhanças apontadas na analogia são sobretudo de aparência. Não há aqui um compromisso com as estruturas do análogo e do alvo.

Nesse nível de elaboração as analogias possuem relações mais aprofundadas. Ainda que por vezes se recorra à semelhança de aparência, esta se dá sobretudo na relação estrutural entre os dois domínios.

São analogias que buscam semelhanças estruturais, mas diferentemente das analogias mecânicas, estas não são baseadas em eventos particulares, ao contrário, estão no sentido da generalização.

A seguir apresentamos, na Figura 6.1, dois subníveis presentes nas relações entre os domínios das analogias. Trata-se, na verdade, da relação de forma ou de aparência presente nas analogias figurativas, e da relação de estrutura, esta característica de analogias mais comprometidas com os conteúdos dos domínios envolvidos na analogia.

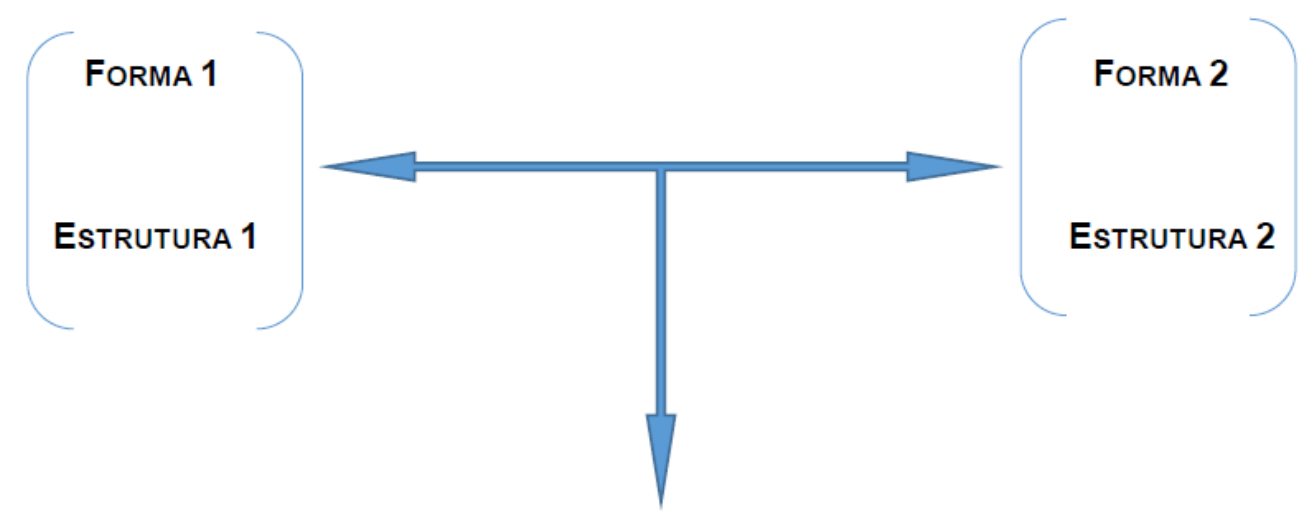

RECONHECIMENTO DE SEMELHANÇAS

Figura 6.1 - Níveis de analogias. 
No Quadro 6.2, apresentamos de que forma o reconhecimento de semelhanças entre os dois domínios pode se apresentar na atividade de uso de uma analogia. Nas analogias figurativas, as relações presentes estão sobretudo no nível mais "frágil" de comparações e reconhecimentos das semelhanças. Estas guardam entre si uma evidente semelhança que é aparente, no entanto, sua "força" está em simplesmente tornar familiar o que é apresentado como novo. Apesar de toda a sua fragilidade, não nos colocamos contrários ao seu uso, afinal não julgamos desprezíveis ações didáticas que buscam tornar familiar o conteúdo apresentado em sala de aula. Entretanto, o uso deliberado de analogias figurativas, sobretudo sem levar em consideração suas limitações, provavelmente não atinge os objetivos do ensino de compartilhar os conceitos pertencentes à área de conhecimento em questão.

Quadro 6.2 - Relações entre os domínios em cada nível de analogia

1. ANALOGIas Figurativas RECONHECIMENTO DA FORMA 2 COMO CASO PARTICULAR
DA FORMA 1

2. ANALOGIAS MECÂNICAS

\ RECONHECIMENTO DA ESTRUTURA 2 COMO CASO PARTICULAR DA ESTRUTURA 1

A mesma estrutura (MATEMÁtica) é APLicável a DIFERENTES DOMÍNIOS. ESTA ESTRUTURA É INSPIRADA NA ESTRUTURA 1 MAS QUE NÃO SE RESUME A ELA (NÃO SE CONSTITUI COMO CASO PARTICULAR).

3. ANALOGIAS MATEMÁTICAS

Nova estrutura (MATEMática) QUe reúne as SEMELHANÇAS ENTRE AS DUAS ESTRUTURAS. 
Já no segundo nível de analogias, as analogias mecânicas propiciam relações estruturais entre os dois domínios que as constituem. É possível detectar também nesse nível semelhanças de aparência ou forma, no entanto estas servem apenas como introdução a semelhanças mais "profundas". Um exemplo clássico de analogia mecânica presente no domínio da física é analogia que busca relação de semelhança entre um circuito elétrico e um sistema hidráulico (semelhante em forma). Neste o fluxo de água é análogo à corrente elétrica (que pode aqui ganhar um status de fluxo de cargas), a resistência elétrica é comparada ao atrito entre a água e as paredes internas do cano. Por meio desta, busca-se entender os conceitos vinculados a um circuito elétrico, identificando as semelhanças estruturais e de funcionamento associadas ao sistema hidráulico. Poincaré (1899) vai destacar que nos trabalhos de Maxwell encontramos potenciais exemplos de analogias mecânicas. Na tentativa de apresentar o conceito de correntes de deslocamento que atravessam um dielétrico, e diferenciá-las de correntes ordinárias de condução que atravessam condutores, o físico alemão associa às primeiras o conceito de resistência elástica (como a presente nas molas), e às segundas o conceito de resistência viscosa (como a presente na situação física de um corpo que se movimenta no interior de um líquido). Como destaca Poincaré (ibidem), apesar de as analogias mecânicas serem consideradas figurativas e de tratarem ainda de casos particulares, estas apresentam um grande potencial na compreensão de novos fenômenos.

As analogias matemáticas são apresentadas em um nível de relações estruturais mais avançado que as analogias mecânicas, pois as primeiras buscam na estrutura matemática a possibilidade de generalização. Destacamos em princípio dois resultados de comparações estruturais provenientes das analogias matemáticas. $O$ primeiro reconhece, na estrutura matemática que descreve 0 fenômeno já conhecido semelhanças aplicáveis ao novo fenômeno. Um exemplo seria o conceito matemático de fluxo que pode ser aplicado em diferentes contextos físicos como na hidrodinâmica, na termodinâmica e no eletromagnetismo. Ainda que persista a relação figurativa do fluxo real de certo fluido, é sua estrutura matemática que aqui destacamos. Mais claramente, a função potencial de Laplace $\Delta \mathrm{V}=\frac{d^{2} V}{\mathrm{dx}}+$ 
$\frac{d^{2} V}{d y}+\frac{d^{2} V}{d z}$, que é aplicável à mecânica dos fluidos, ao eletromagnetismo e a termodinâmica.

No segundo caso, a estrutura matemática de relação emerge da semelhança estrutural existente entre os dois domínios. Normalmente aí reside o processo de criação.

\subsubsection{Quanto ao formato de apresentação}

A categoria formato de apresentação está presente nos trabalho de Curtis e Reigeluth (1984) e de Queiroz (2000). Segundo os referidos trabalhos, são duas as classificações para o presente critério, a saber, a verbal e a pictórico-verbal. No entanto, como destacamos em diversas partes do nosso texto, a presente tese se propõe pensar em analogias inseridas em atividades de ensino de física quântica, particularmente olhamos para as ações dos professores. Dado a dinâmica do contexto empírico de nossa pesquisa, e a especificidade do domínio da física a partir do qual pautamos nossa investigação, criamos o formato verbal-representativo que, ao nosso ver, engloba as características do formato pictórico-verbal e aumenta sua amplitude. Na verdade, foi a partir de nossos dados que percebemos a possibilidade de o professor recorrer a diversas formas representativas a fim de reforçar sua narrativa. Nas categorias anteriores, o formato pictórico-verbal proposto por Curtis e Reigeluth (idem) está restrito a representações pictóricas (figuras e imagens), enquanto no formato verbal-representativo podemos incluir outras formas de reforçar a narrativa presente na apresentação da analogia.

Um dos episódios analisados na presente tese mostra a ação de um professor que recorre a uma encenação da qual os alunos participam. O referido professor busca demonstrar semelhanças entre o movimento em espiral de bolas de gude sobre um lençol esticado pelos alunos, contendo em seu centro uma bola de ferro capaz de deformá-lo, e o colapso dos elétrons com o núcleo no modelo clássico proposto por Rutherford. Apresentamos no Quadro 6.3 três sequências retiradas do episódio relativo à aula supracitada. 
Quadro 6.3 - Episódio 02 (MAT -02-11032011-06) $)^{51}$

\begin{tabular}{|c|c|c|c|}
\hline S. & No. Do turno (Sujeito) Transcrição & Ações no turno & Identificação de elementos da analogia. \\
\hline \multirow[t]{2}{*}{1} & $\begin{array}{l}\text { 1(P) Eu preciso de platéia, e eu preciso } \\
\text { de auxiliares ... deixa eu pegar um cara } \\
\text { bem forte pra me ajudar. }\end{array}$ & $\begin{array}{l}\text { O professor caminha até o final da sala } \\
\text { a fim de pegar o material que será } \\
\text { usado na encenação. }\end{array}$ & \\
\hline & 2( $\left(A_{1}\right)$ Vai lá Will! & & \\
\hline \multirow[t]{5}{*}{2} & $\begin{array}{l}3(\mathrm{P}) \text { O Nosso núcelo do átomo é um } \\
\text { pouquinho pesado }\end{array}$ & $\begin{array}{l}\text { O professor empresta a bola de ferro a } \\
\text { aum aluno que a segura. Em seguida ele } \\
\text { a faz passar aos demais colegas. }\end{array}$ & A bola de ferro é o análogo do núcleo \\
\hline & $\begin{array}{l}4\left(\mathrm{~A}_{1}\right) \text { Cara, o moleque está quase } \\
\text { caindo (risos). }\end{array}$ & & \\
\hline & $\begin{array}{l}5(\mathrm{P}) \text { é um pouquinho pesado o nosso } \\
\text { núcleo? }\end{array}$ & & \\
\hline & $6\left(\mathrm{~A}_{2}\right) \mathrm{O}$ que é isso? & & \\
\hline & 7(P) O núcleo do nosso átomo & & $\begin{array}{l}\text { Reforço da analogia (bola de ferro como } \\
\text { análogo do núcleo) }\end{array}$ \\
\hline 3 & $\begin{array}{l}\text { 8(P) Isso aqui va simular o nosso } \\
\text { campo eletrônico, a núvem onde o } \\
\text { elétron está }\end{array}$ & O professor destaca o lençol. & $\begin{array}{l}\text { O lençol é o análogo do que ele chama de } \\
\text { espaço eletrônico. }\end{array}$ \\
\hline
\end{tabular}

Finalmente, a partir das categorias de analogias apontadas por Poincaré, inserimos um novo formato de apresentação de analogias, a saber, o matemático representativo. Diferentemente do formato anterior, que surgiu da elaboração e análise dos dados, este se apresenta como resultado de nossa análise teórica (quadro 6.4). Na verdade, uma vez que identificamos, na dimensão epistemológica, uma "classe" de analogias denominada "analogia matemática", julgamos possível uma relação analógica que leve em conta não semelhanças de forma ou figurativas, mas sobretudo aquelas mais "profundas", estruturais e "generalizantes" 52.

\footnotetext{
${ }^{51}$ A fim de elucidar o presente código alfa-numérico, apresentaremos na seção 5.4 um quadro relativo à identificação de um episódio.

${ }^{52}$ A palavra "generalizante" é aqui aplicada no senso de Poincaré. Como destaca Paty (2008), sob a perspectiva poincareana, a função da analogia é conduzir à generalização, e isso é aplicável tanto à matemática, quanto à física.
} 
Quadro 6.4- Características que orientam a análise metodológica da categoria "formato de apresentação".

\section{Formato de Apresentação}

Verbal

A analogia é apresentada pelo uso exclusivo de palavras (textual ou verbal) numa perspectiva narrativa de fatos.

Verbal-Representativo

Semelhante ao formato verbal, esta categoria reúne ações de ordem narrativa. No entanto, no intuito de enfatizar a narrativa, esta é reforçada por representações pictóricas, ou até mesmo de encenação.

MatemáticoRepresentativo
Neste formato, o professor geralmente recorre a estruturas matemáticas (geométricas ou algébricas), a partir das quais ele destaca um tipo de semelhança estrutural sem compromisso ontológico entre as entidades físicas representadas.

\subsubsection{Inclusão das atividades didáticas de uso de analogias no planejamento}

De acordo com nosso levantamento bibliométrico, o tema uso de analogias em aulas de ciências como ferramenta didática está presente de forma relevante no conjunto de trabalhos (dissertações, teses e artigos) da área especializada nos últimos 25 anos. Não encontramos muitos trabalhos que reprovassem categoricamente o seu uso, na verdade o que encontramos são orientações e "forma de uso".

Apontamos, portanto, o conjunto de trabalhos presentes em Harrison e Coll (2008), intitulados "Using Analogies in Middle and Secondary Science Classrooms", e destacamos o trabalho de Venville (ibidem), cujo título é "The Focus-ActionReflection (FAR) Guide- Science Teaching Analogies".

Como ressaltamos no capítulo 5 , o referido trabalho reforça a ideia da necessidade de sistematizar $\mathrm{o}$ uso de analogias em atividades didáticas. O pensamento central do trabalho de Venville é o do uso de analogias em três momentos didáticos, a saber, anterior à ação (planejamento - "Focus"); durante a ação (na aula- "Action"); e posterior à ação (avaliação- "Reflection"). No entanto, a presente categoria visa classificar ações didáticas no momento da aula, mas que podem apresentar indícios de ações prévias. 
Além do trabalho supracitado, a ideia de alteração do status do senso comum presente em Paty (2003) foi fundamental na elaboração da presente categoria, assim como na de seus itens. As especificidades inerentes ao domínio da física quântica reforçam a necessidade de integrar o uso de analogias voltadas ao ensino de seus conceitos às atividades de planejamento do professor, mas sobretudo de buscar, através de ações prévias, mudanças no status de senso comum dos alunos. $\mathrm{Na}$ verdade, é pelo processo de categorização-e-analogia que "elevamos" o status dos conceitos já pertencentes à estrutura cognitiva do sujeito a níveis que se alternam entre a generalização e a objetivação. Apesar de aqui tratarmos de conceitos cada vez mais abstratos e complexos, como: discreto x contínuo; quanta; fótons; colapso; observáveis; dualidade onda-partícula, a referida alternância se dá de forma similar à de situações ordinárias. No exemplo do pequeno Vicente, no qual a criança se apropriava do conceito $<$ mamãe $>>$, percebemos que o referido conceito ganhava amplitude à medida em que novos "elementos/objetos" do mundo se incorporavam a esta categoria (movimento de generalização), mas ao mesmo tempo ganhava refinamento, à medida que ele conseguia, em seu uso, diferenciar os elementos dessa nova ampla categoria (movimento de objetivação).

Foi então, baseados em nossas reflexões teóricas, assim como por meio da construção de nossos dados, que identificamos três itens pertencentes à categoria "Indicações de Ações Prévias".

Para classificação dos episódios, utilizamos basicamente dois parâmetros. 0 primeiro diz respeito ao acesso a aulas anteriores e ligadas ao tema da aula analisada, já o segundo diz respeito à ação do turno em questão. Buscamos na própria narrativa do professor elementos de conexão que fizessem menção a abordagens prévias, tais como "vocês lembram o que discutimos...", ou "... conforme vimos na aula passada...". Na verdade, foi o cruzamento dos dois parâmetros que nos permitiu classificar os episódios. O Quadro 6.5 apresenta os três níveis da categoria "Ações Prévias". 
Quadro 6.5- Características que orientam a análise metodológica da categoria "Ações Prévias"

\begin{tabular}{ll}
\hline \hline \multicolumn{1}{c}{ Indicações de Ações Prévias } \\
\\
\hline Ausência & $\begin{array}{l}\text { A analogia conta apenas com a percepção imediata dos alunos, } \\
\text { sem qualquer relação com os conceitos que estão sendo } \\
\text { apresentados. Os alunos são "pegos de surpresa" com a } \\
\text { mudança na narrativa. }\end{array}$
\end{tabular}

Sincrônica à ação de uso A analogia é precedida por uma breve apresentação, a fim de preparar os alunos para a mudança de domínio que se segue.

Anterior à ação de uso Percebem-se aqui ações prévias intencionais, em momentos anteriores à ação presente, que buscaram estabelecer um novo status de senso comum.

Tentamos olhar, por meio da presente categoria, se os professores, cujas aulas sobre temas da física quântica analisamos, incluíram as analogias, das quais eles lançaram mão, em seu planejamento didático, e se sim, em que nível. Vale destacar que estas aulas são resultado do curso de formação continuada de professores, realizado na USP, e voltado à implementação de temas de física moderna no ensino médio. Na verdade, como descrevemos no contexto empírico, as atividades foram desenvolvidas no curso e aplicadas pelos professores em suas respectivas turmas do ensino médio.

\subsubsection{A unidade de análise}

Buscamos um aspecto metodológico que venha permitir a análise do que denominamos "episódios de ensino". Na verdade, antes mesmo da análise, é necessária a seleção dos referidos episódios, ou seja, os "momentos extraídos de uma aula, onde fica evidente o que queremos investigar" (CARVALHO, 2006). Particularmente, na presente pesquisa, tais momentos nos parecem evidentes uma vez que queremos investigar o uso de analogias nas aulas registradas. Mesmo assim, baseados no trabalho de Martins (2006), e fortemente influenciados pela estrutura de construção de mapas de eventos de Araújo Neto (2009), buscamos 
organizar nossos dados em mapas que classificam os eventos em três categorias: 1quanto à classificação funcional do evento ou natureza do evento: 2- quanto aos tópicos abordados; e quanto aos recursos utilizados pelos professores.

Cada aula reúne uma sequência de eventos $(\mathrm{N})$, e estes podem ser de quatro naturezas, a saber, organizativa, explicativa, participativa e introdutória. Constam nos mapas a duração de cada evento, a sua natureza, o tópico ao qual este faz referência, os recursos utilizados pelo professor, assim como uma descrição detalhada do evento. Buscamos, assim, elaborar um quadro geral que nos permitisse, baseados nas categorias aqui apresentadas, extrair com mais facilidade os referidos episódios de ensino. A Figura 5.2 representa um fragmento de uma aula com os três primeiros eventos. Os mapas de eventos completos se encontram no apêndice $A$.

\begin{tabular}{|c|c|c|c|c|c|c|}
\hline \\
\hline $\mathbf{N}$ & Inicio & Fim & Natureza do ev ento & Tópico & Recursos & Descrição detalhada \\
\hline 1 & $00: 00$ & $01: 56$ & $\begin{array}{l}\text { (O) Iniciando a aula. Professor } \\
\text { explica a presença da camera e } \\
\text { fala sobre o projeto FM no ensino } \\
\text { médio. }\end{array}$ & & & $\begin{array}{l}\text { profess or pass a algumas orient ações a respeitodas tarefas pass adas } \\
\text { para casa. }\end{array}$ \\
\hline 2 & $01: 56$ & $04: 29$ & $\begin{array}{l}\text { (E) Introdução ao estudo de fisica } \\
\text { moderna. }\end{array}$ & (DOP) & (V) (T) & $\begin{array}{l}\text { O professor destaca a natureza dual da luz. Com a intenção de } \\
\text { envolver os alunos nas discussões que se seguem, o professor } \\
\text { simvla uma situação de furto de um pedaço de chocolate. A partie } \\
\text { da presente sitvação, os convida a pensar como a fisica pode ser } \\
\text { útil na resolvção do referido caso. }\end{array}$ \\
\hline 3 & $04: 29$ & $06: 03$ & $\begin{array}{l}\text { (Introdutório) Video produzido } \\
\text { pelos alunos. }\end{array}$ & & (P) & $\begin{array}{l}\text { O professor apresenta uma edição de um video denominado "CSI- } \\
\text { LICEU", que conta com o profess or como um dos atores, dentre o } \\
\text { elenco da série original. O video causa risos e parece atingir seu } \\
\text { objetivo. }\end{array}$ \\
\hline
\end{tabular}

Figura 6.2. Fragmento do mapa de eventos relativo à aula 02

Os mapas de eventos se apresentaram como elementos de organização das aulas videografadas. Dessa forma, os registros em vídeo puderam ser convertidos em dados e conseguimos criar os episódios de ensino, a partir dos quais realizamos nosso ensaio empírico.

Assim como Araújo Neto (ibidem), não fazemos distinção entre dois eventos organizativos a menos que estes sejam alternados por um evento de outra natureza. Como no exemplo da Figura 6.2, no qual dois "eventos" organizativos são seguidos, o professor inicia a aula relembrando as tarefas anteriores, passadas para casa, e em seguida explica a presença da câmera na sala de aula. Eventos explicativos 
foram delimitados essencialmente pela mudança do tema abordado. Os eventos participativos são delimitados entre a orientação do professor para realização de uma tarefa em sala de aula pelos alunos, seja individual ou em grupo. Já eventos de natureza introdutória visa caracterizar ações do professor que não estejam ligadas diretamente ao tema da aula, mas que buscam inserir os alunos nas questões que se seguem. O Quadro 6.6 representa os quatro tipos de natureza de eventos aqui sugeridos.

Quadro 6.6- Características do item "natureza do evento" para o mapa de eventos.

\begin{tabular}{ll}
\hline Natureza do evento & \\
\hline \hline Organizativo (O) & $\begin{array}{l}\text { Destina-se à organização das atividades da aula, pedido de silêncio, } \\
\text { anúncios e outras intervenções voltadas ao início da aula ou de uma nova } \\
\text { atividade. }\end{array}$ \\
Explicativo (E) & $\begin{array}{l}\text { Destina-se à produção de um enunciado sobre um conceito ou objeto, } \\
\text { estabelecendo relações entre eles. } \\
\text { As dúvidas levantadas pelos alunos e as referidas explicações. }\end{array}$ \\
Participativo (P) & $\begin{array}{l}\text { Destina-se a atividades realizadas pelos alunos sob a coordenação do } \\
\text { professor (exercícios, trabalho em grupo, experimentos, etc.). }\end{array}$ \\
Introdutório (I) & $\begin{array}{l}\text { Destina-se a atividades de introdução a um turno. Geralmente são ações } \\
\text { sem compromisso direto com os conceitos físicos abordados. Evento que } \\
\text { busca o envolvimento dos alunos na aula que se segue (vídeos, histórias, } \\
\text { etc.). }\end{array}$
\end{tabular}

Julgamos essencial incluir em nosso mapa de conceitos um quadro descritivo dos tópicos abordados pelos professores em suas aulas. $\mathrm{Na}$ verdade, como apontamos anteriormente, do conjunto de aulas por nós analisados, foram selecionadas aquelas que apresentavam temas ligados à física quântica. A partir de nossa leitura, destacamos no Quadro 6.7 quatro tópicos que julgamos pertinentes à construção dos episódios. 
Quadro 6.7- Características do item "tópicos" para o mapa de eventos

\begin{tabular}{ll}
\hline \hline Tópicos & Explicação do modelo de Bohr empregando a física \\
Quantização da energia (QE) & $\begin{array}{l}\text { clássica e a hipótese quântica de Planck. Faz-se uma } \\
\text { relação entre contínuo e discreto, buscando, assim, } \\
\text { evidenciar uma nova característica do mundo } \\
\text { subatômico. }\end{array}$ \\
Características dos modelos (CM) & $\begin{array}{l}\text { Apresentação de alguns modelos atômicos } \\
\text { destacando suas características, e quais as questões } \\
\text { inerentes a esses que mostravam sua } \\
\text { incompatibilidade com a natureza da matéria e suas } \\
\text { contradições com os experimentos até então } \\
\text { conhecidos. } \\
\text { Dualidades onda-partícula (DOP) } \\
\text { Apresentação de alguns experimentos que "dão" à luz } \\
\text { ora características corpusculares ora características } \\
\text { ondulatórias (interferômetro de Mach-Zehnder). }\end{array}$ \\
& $\begin{array}{l}\text { Apresentação do efeito fotoelétrico. Evidenciar que, } \\
\text { contrariamente ao que prevê a teoria clássica, a } \\
\text { energia dos elétrons ejetados não muda com a } \\
\text { intensidade da luz incidente, e sim com a frequência. }\end{array}$
\end{tabular}

Dentre os temas abordados pelos professores em sala de aula, destacamos aqueles que aparecem como "elementos" de difícil representação, assim como questões relevantes à compreensão dos novos conceitos advindos da física quântica. É então a partir da elucidação dos referidos tópicos, que conseguimos melhor construir nossos episódios.

Durante as ações dos professores, identificamos na construção dos mapas de eventos os recursos por eles utilizados. A construção deste quadro se deu à medida que cada um desses recursos se apresentou como potencial representativo dos elementos de comunicação presentes na narrativa. Ainda que os eventos sejam de diversas naturezas, conforme representado no Quadro 5.6, nosso interesse maior se deu à medida que detectamos ações representativas analógicas. Afinal, nosso dados são construídos a partir do material empírico, mas sobretudo são guiados por nosso interesse de pesquisa orientado por nossos referenciais teóricos. "Os dados 
são, portanto, construídos na interação entre investigador e os cenários - teórico e empírico - da pesquisa e não existem de forma independente do observador nem podem ser objetivamente acessados e descritos." (MARTINS, 2006, p. 300). Foram então identificados cinco modos de recursos na elaboração dos mapas de eventos, os quais listamos de forma detalhada no Quadro 6.8.

Quadro 6.8- Características do item "recursos" para o mapa de eventos

\section{Recursos}

Verbal (V)

Gráfico Pictórico (P)

Gestual (G)

Material ( $\mathrm{T})$

Gráfico Matemático (M)
Esta categoria é atribuída quando o professor recorre a narrativas comparativas que suscitam analogias. Geralmente o professor interage com a turma de forma a incluir uma situação particular na narrativa.

Esta categoria é atribuída quando o professor utiliza o quadro ou outro meio de suporte gráfico (escrita) na tentativa de reforçar um enunciado. O recurso gráfico pictórico inclui diversos meios (quadro, slide, filme, animação, etc.).

Quando o professor lança mão de gestos, a fim de representar um elemento o qual deseja comunicar. Não foram incluídos nesta categoria gestos que representam ênfase no discurso ou qualquer tipo de indicação como posição, sentido, etc.

Por vezes os professores lançam mão de um meio material como suporte em dada atividade, assim como elemento representativo no processo analógico.

Consideramos que o recurso gráfico matemático é utilizado quando o professor recorre a relações estruturais de comparação. Por vezes o professor lança mão de estruturas matemáticas (equações, fórmulas, etc.) a fim de buscar ali semelhanças entre dois domínios distintos.

A presente pesquisa tem como objetivo focalizar as analogias usadas na tentativa de representação de conceitos ligados à física quântica. Para isso, além do discurso do professor, destacam-se em sua narrativa os recursos usados, assim como o conteúdo por ele abordado em cada ação analógica. Esta, portanto, se constitui nossa base para construção dos mapas de eventos. No entanto, como destaca Martins (2006): "Nem o mapa nem a transcrição descrevem de forma objetiva e completa a sequência de eventos registrados na aula, mas eles 
certamente destacam quais eventos são significativos com relação aos nossos interesses específicos." (p.311).

\subsection{Recorte de episódios para análise}

Como destacamos na seção anterior, o mapa de eventos se apresenta como uma primeira ação na busca por transformar nossas aulas videografadas em dados. Como destaca Araújo Neto (2009): "Um evento é uma macroestrutura que comporta diversas situações, pode envolver um único conteúdo curricular, mas abraçar diferentes tópicos e colocar em uso diversas ferramentas." (p.129). Apesar dessa primeira ação se constituir fundamental no processo descrito, é necessário o segundo momento de ação na construção dos dados.

A partir de nosso mapa de eventos, que nos fornece um panorama geral, construído com base em nosso interesse de pesquisa, propomos o recorte dos eventos que se constituirão nos episódios específicos, objetos de nossa análise. Como nosso foco se dá em ações analógicas, especificamente voltadas a temas de física quântica, o principal critério na construção dos episódios de ensino trata de reconhecer, no primeiro momento, eventos nos quais tais ações ocorrem. Tendo em vista as especificidades de nossos episódios, descartamos eventos que não sejam de natureza explicativa ${ }^{53}$, ligados aos conceitos em questão. De fato, o presente critério nos permite selecionar um conjunto de eventos com considerável grau de objetividade. Por isso reforçamos a importância do cuidado na construção do mapa de eventos, pois a partir deste, e de acordo com os critérios escolhidos em sua elaboração, construímos nossos episódios com mais ou menos dificuldade.

O Figura 6.3 corresponde a um fragmento da aula 04, na qual podemos identificar dois eventos que são caracterizados como de natureza "híbrida". Sinalizamos também, nos mapas, com um asterisco $\left({ }^{*}\right)$, eventos que contêm analogias e por isso serão utilizados na construção de episódios.

\footnotetext{
${ }^{53}$ Alguns eventos foram carcaterizados como tendo uma natureza "híbrida" devido à presença de carcaterísticas distintas dentro de uma mesma atividade. Decidimos atribuir o presente "status" a certos eventos, quando a alternância da natureza se deu várias vezes em curtos intervalos de tempo.
} 


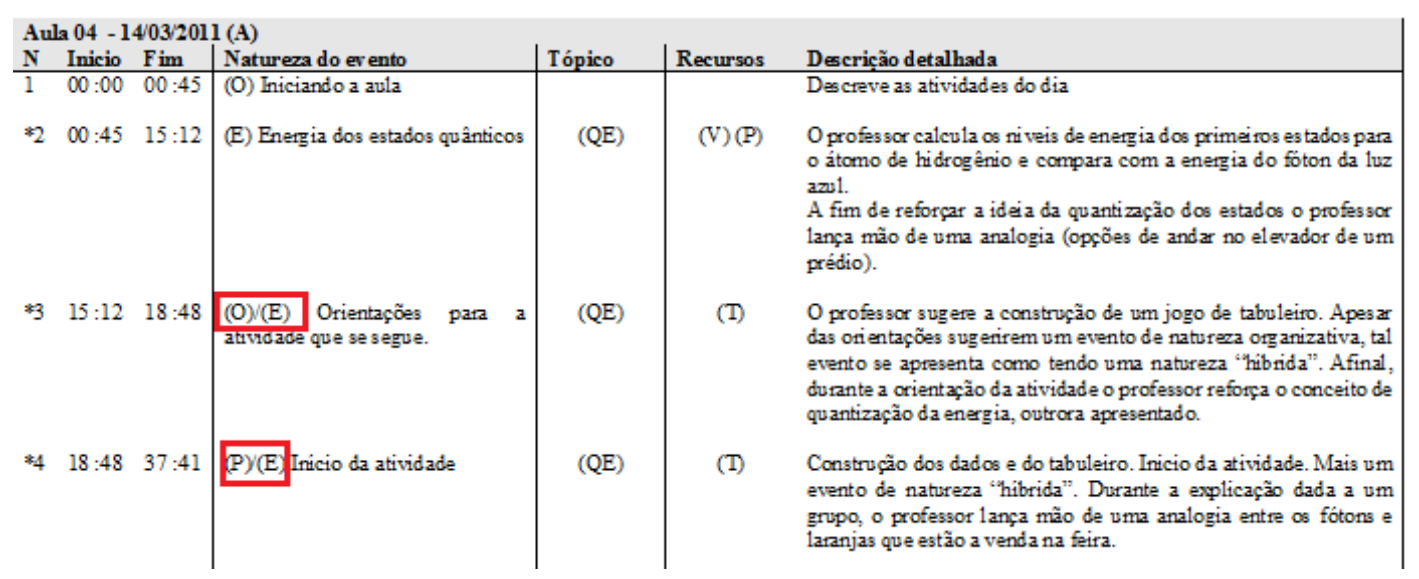

Figura 6.3. Fragmento do mapa de eventos relativo à aula 04

Destacamos também que foi essencial explicitar os tópicos presentes em cada evento, visto que isso tornou possível buscar elementos de representação analógica associados ao conteúdo ali trabalhado. Em nosso ensaio empírico, geralmente os conceitos que "suscitavam" o uso de analogias na busca do compartilhamento de significados com os alunos, a priori, estavam concentrados em dois conceitos, a saber, o conceito de quantização da energia (associado ao modelo atômico de Bohr, e associado ao efeito fotoelétrico); e o da dualidade onda-partícula. Ainda baseados nos trabalhos de Martins (2006) e de Araújo Neto (2009), apresentamos o Quadro 6.9 como padronização da identificação de nossos episódios.

Quadro 6.9- Padrão de identificação dos episódios

\begin{tabular}{ll}
\hline \hline $\begin{array}{l}\text { Identificação do } \\
\text { episódio }\end{array}$ & TTT- NN-DDMMAAAA- EE \\
\hline \hline TTT & $\begin{array}{l}\text { Tema da aula: } \\
\text { MAT }=\text { Modelos Atômicos } \\
\text { EFE }=\text { Efeito fotoelétrico } \\
\text { NDL }=\text { Natureza da Luz }\end{array}$ \\
& Numero da Aula \\
NN & $\begin{array}{l}\text { Data da aula: } \\
\text { DD = Dia } \\
\text { DDMMAAAA }\end{array}$ \\
& AAAA = Ano \\
& Número do evento correspondente ao referido episódio \\
\end{tabular}


Apesar de as características aparecerem no Quadro 6.9 na vertical, as descrições estão dispostas em uma única linha, na parte superior da apresentação de cada episódio. O quadro correspondente conta com quatro colunas, a saber, a sequência de turnos de fala; a numeração dos turnos, com o sujeito e a respectiva transcrição; a correspondente ação de turno; e a identificação de elementos da analogia usada. Apresentamos, na Figura 6.4, uma sequência relativa ao episódio 02, cujo tema é modelos atômicos.

Episódio 02 (MAT -02-11032011-06) - Instabilidade do átomo de Rutherford

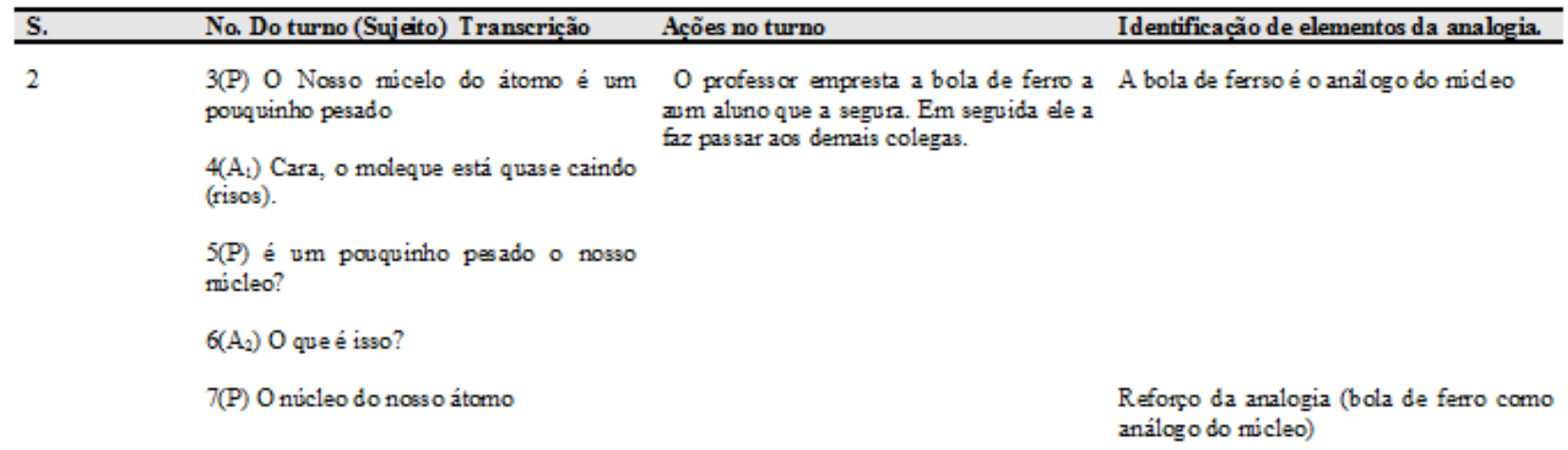

Figura 6.4 - Fragmento do quadro relativo ao episódio 02

A numeração dos turnos é sequenciada e a identificação dos sujeitos é dada por (P), quando o sujeito da fala for o professor, e por (A) quando o sujeito da fala for um aluno. Usamos, no entanto, os índices numéricos quando o sujeito da fala for um aluno, a fim de diferenciá-lo quando necessário $\left(A_{1}, A_{2}, \ldots\right)$, ou $n$, caso o sujeito da fala seja um grupo de alunos $\left(A_{n}\right)$. Na ação de turno, relatam-se aspectos que julgamos relevantes na descrição do contexto do referido turno. Já na última coluna, baseados em nossa reflexão relativa à dimensão didática do uso de analogias, identificamos os elementos envolvidos na analogia utilizada na respectiva sequência.

Finalmente, a partir de nossa estrutura teórico-metodológica, propomos o ensaio empírico como resultado da presente pesquisa. Tentamos, neste capítulo, elucidar a construção de nossa ferramenta metodológica, que busca, a partir do estudo de caso, trazer elementos de contribuição para as práticas didáticas de uso de analogias. Mais especificamente, pretendemos analisar como nossa síntese 
teórica a respeito do referido tema pode ser utilizada em ações práticas do uso de analogias em aulas de física quântica voltadas a alunos do ensino médio. 
CAPÍTULO 7 


\section{ESTUDO DE CASO}

Há um problema capital, ainda desconhecido, que é a necessidade de promover um conhecimento capaz de abordar problemas globais e fundamentais a partir dos quais trataremos dos conhecimentos locais e parciais.

A supremacia de um conhecimento fragmentado em disciplinas geralmente nos incapacita de trabalhar com as relações entre as partes a as totalidades. Esta deve ceder lugar a um modo de conhecimento capaz de se apropriar de seus objetos em seus contextos, suas complexidades, seus conjuntos.

Todo conhecimento traz consigo o risco do erro e da ilusão. $A$ educação deve encarar este problema de duas faces do conhecimento.

(Edgar Morin, 200,p.12 e 17) 
Buscamos, na presente tese, pensar no uso de analogias em atividades didáticas relacionadas à física quântica. Baseados em nossos referenciais teóricos, e a partir do registro em vídeo de aulas de temas associados ao referido domínio da física, construímos mapas de eventos, do interior dos quais selecionamos os episódios que serão analisados no presente capítulo. A partir das categorias apresentadas anteriormente, pretendemos construir um conjunto de dados que nos permita olhar para atividades de uso de analogias em aulas de física quântica voltadas a turmas do ensino médio.

Do conjunto de oito aulas que geraram nossos mapas de eventos, destacamos oito episódios a partir dos quais propomos nosso estudo de caso. Consideramos como critério de seleção dos episódios situações explicativas de conceitos ligados à física quântica nas quais os professores lançavam mão de analogias. Na verdade, não foi difícil identificar tais situações, na medida em que estas eram caracterizadas pela mudança "súbita" de tema na narrativa. Mesmo em situações nas quais a analogia não foi anunciada como tal, foi possível identificar, no respectivo turno, que se tratava de uma situação de uso da referida ferramenta representativa. Foram também identificadas, na introdução de um turno que trataria de uma analogia, algumas expressões como: "É como se você pensasse assim (...)"; "Por exemplo, (...)"; "Pessoal, vamos pensar (...)", no entanto, apesar de termos nessas expressões um elemento indicativo, nem sempre assim ocorreu. Algumas mudanças de turnos que resultaram na narrativa de uma situação analógica aparecem como uma ruptura na narrativa anterior, fundamentalmente porque o novo turno tratava de um tema em princípio sem nenhuma relação com o que estava sendo apresentado anteriormente. Destacamos, na Figura 7.1, um fragmento do episódio 05, que representa um exemplo de mudança brusca na narrativa do professor ao introduzir um novo turno. 


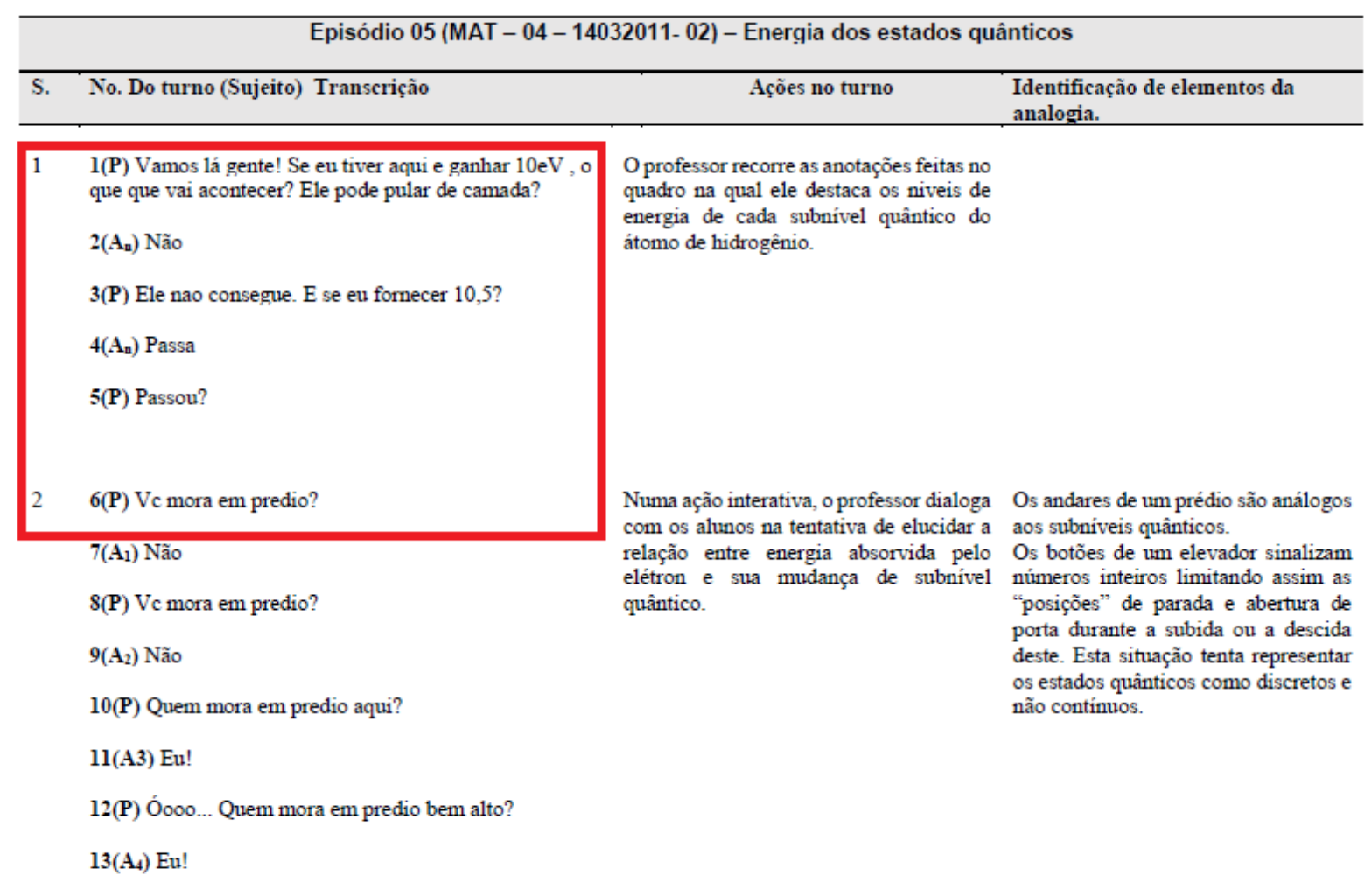

Figura 7.1 - Fragmento do episódio 05 (MAT - 04 - 14032011 - 02)

Os temas abordados nos episódios selecionados são: a quantização da energia (tanto no modelo atômico de Bohr, como na explicação do efeito fotoelétrico); o comportamento corpuscular da luz (presente na explicação do efeito fotoelétrico); e a dualidade onda-partícula (apresentada nas interpretações da mecânica quântica através do interferômetro de Mach-Zehnder).

Foi então que, mediante os dados construídos a partir das aulas de quatro professores do ensino médio, propusemos um ensaio empírico (aqui denominado estudo de caso), tendo por base as categorias que foram resultado de nosso estudo teórico nas três dimensões tratadas em capítulos anteriores.

Por meio de nossas categorias, buscamos classificar os episódios selecionados. Nosso ensaio empírico visou fundamentalmente perceber de que forma as analogias podem aparecer nas ações dos professores quando estes têm por função comunicar conceitos associados à física quântica. A seguir, selecionamos o episódio 03 (EFE - 03 - 14032011 - 05), a fim de demonstrar como os três conjuntos de categorias propostos na presente tese podem nos dar um 
panorama geral de classificação das atividades analógicas presentes no conjunto de eventos aqui apresentados.

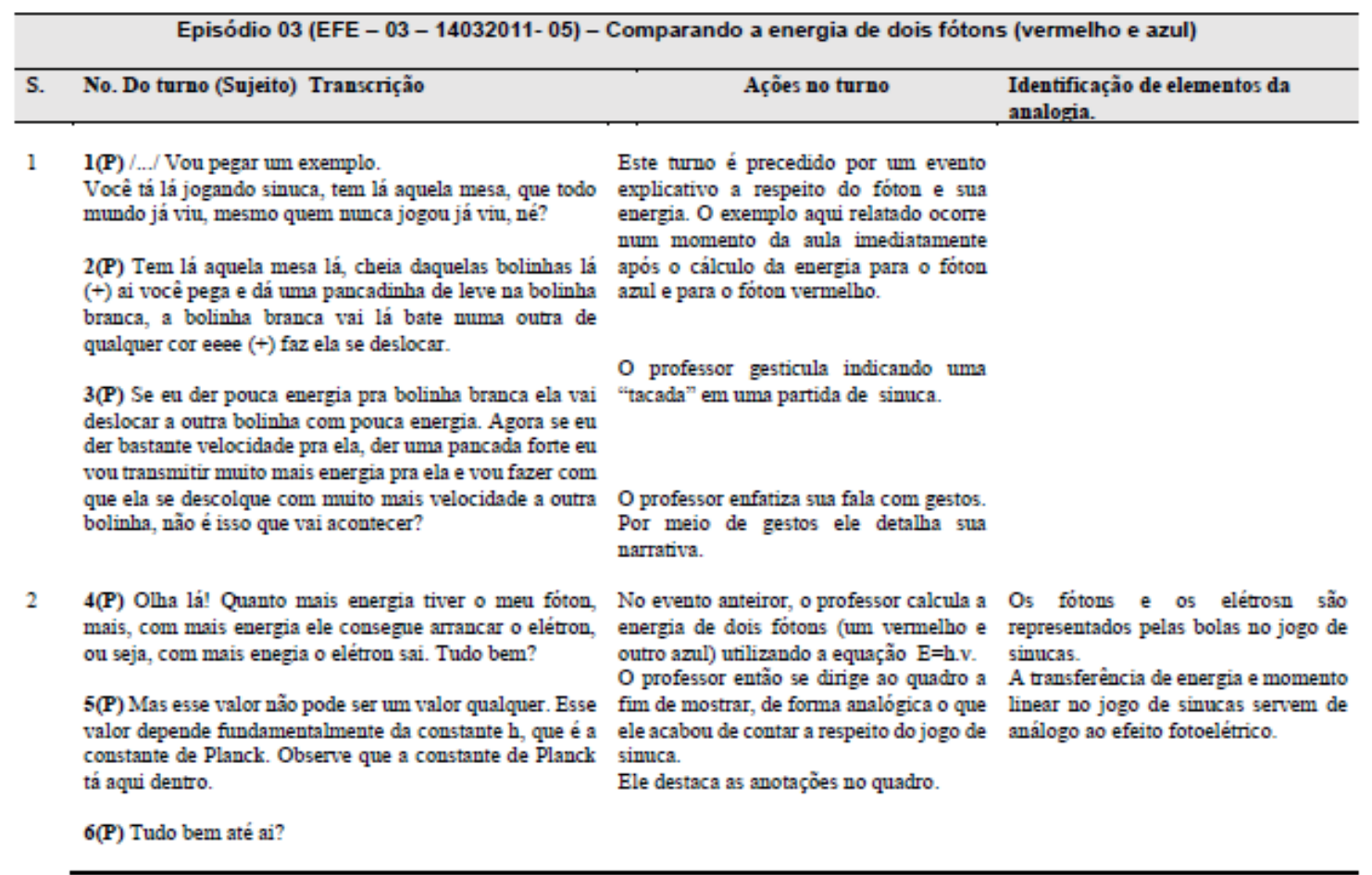

Figura 7.2 - Episódio 03 (EFE - 03 - 14032011 - 05)

O episódio em questão está inserido no contexto de uma aula de física cujo tema central é o efeito fotoelétrico (EFE). Na referida aula, o professor buscava apresentar o referido fenômeno físico a partir do modelo corpuscular da luz, este tendo sido já apresentado e discutido em aulas anteriores. As duas sequências de turnos apresentam ações exclusivas do professor que buscam reforçar a compreensão do EFE como um fenômeno corpuscular. Para isso o professor lança mão de uma analogia a partir da qual ele propõe a semelhança entre os dois fenômenos, a saber, a transferência de momento linear envolvida em uma jogada de certa partida de sinuca, e aquela dada na interação entre a luz (fótons) e a placa de dado material (elétrons).

Quanto ao nível, a descrição da ação analógica feita no parágrafo anterior nos permite classificar a analogia inserida na referida atividade como "Mecânica". A semelhança destacada pelo professor não se atém a características da forma dos 
objetos ali envolvidos, mesmo que possamos ser levados a pensar nos fótons e elétrons como as bolas de sinuca. Antes, porém, a ênfase é dada à relação transferência de momento linear presente no jogo de sinuca e generalizada para o EFE.

Já no formato de apresentação, as ações descritas nos turnos indicam o formato "Verbal-Representativo", uma vez que acompanhamos a narrativa do professor seguida do reforço com ferramentas pictóricas presentes no quadro. Vale ressaltar que algumas anotações no quadro eram correspondentes aos cálculos das energias de dois fótons, um vermelho e outro azul, o que poderia sugerir, em princípio, o uso do formato "Matemático-Representativo". No entanto, como descrevemos no Quadro 5.4, "neste formato, o professor geralmente recorre a estruturas matemáticas (geométricas ou algébricas) a partir das quais ele destaca um tipo de semelhança estrutural sem compromisso ontológico entre as entidades físicas representadas", o que não esteve presente na atividade do episódio 03.

Por último, analisamos o presente episódio a fim de avaliar as indicações de ações prévias. Como destacamos anteriormente, tal conjunto de categorias tem por objetivo investigar o compromisso didático dos professores na elaboração e planejamento de atividades pautadas em analogias que buscam o compartilhamento de significados com os alunos, particularmente em aulas de física quântica. Nossa intenção se estende á medida que tomamos como base teórica o movimento apontado por Paty (2003) como mudança do status do senso comum.

No presente episódio, a analogia é introduzida como "um exemplo". Geralmente, quando um turno é assim iniciado, trata-se de ação analógica com certo grau de planejamento. Na verdade, este não é o único elemento discursivo que pode nos sugerir ações prévias. No entanto, este se apresenta como indicativo que vai nos conduzir a atenção no decorrer da narrativa a outros elementos que possam apontar a existência de tais ações, assim como sugerir em que nível estas ocorreram. Destacamos, no entanto, que, apesar de certa subjetividade inerente a este conjunto de categorias, os objetivos de tal classificação não são guiados pelo rigor na determinação dos limites entre as categorias. Sobretudo, nosso trabalho de categorização foi de fato auxiliado, à medida que tivemos acesso às aulas que antecederam aquelas utilizadas na construção dos episódios analisados. 
Apesar de encontrarmos indícios de ações prévias, a analogia utilizada exigiu dos alunos apenas conhecimentos "ordinários". Mesmo tendo destacado que a relação de semelhança entre os dois dominós apresentados (análogo e alvo) não é baseada na forma e sim na "estrutura de funcionamento" de ambos, os elementos discursivos utilizados pelo professor estão no nível do senso comum.

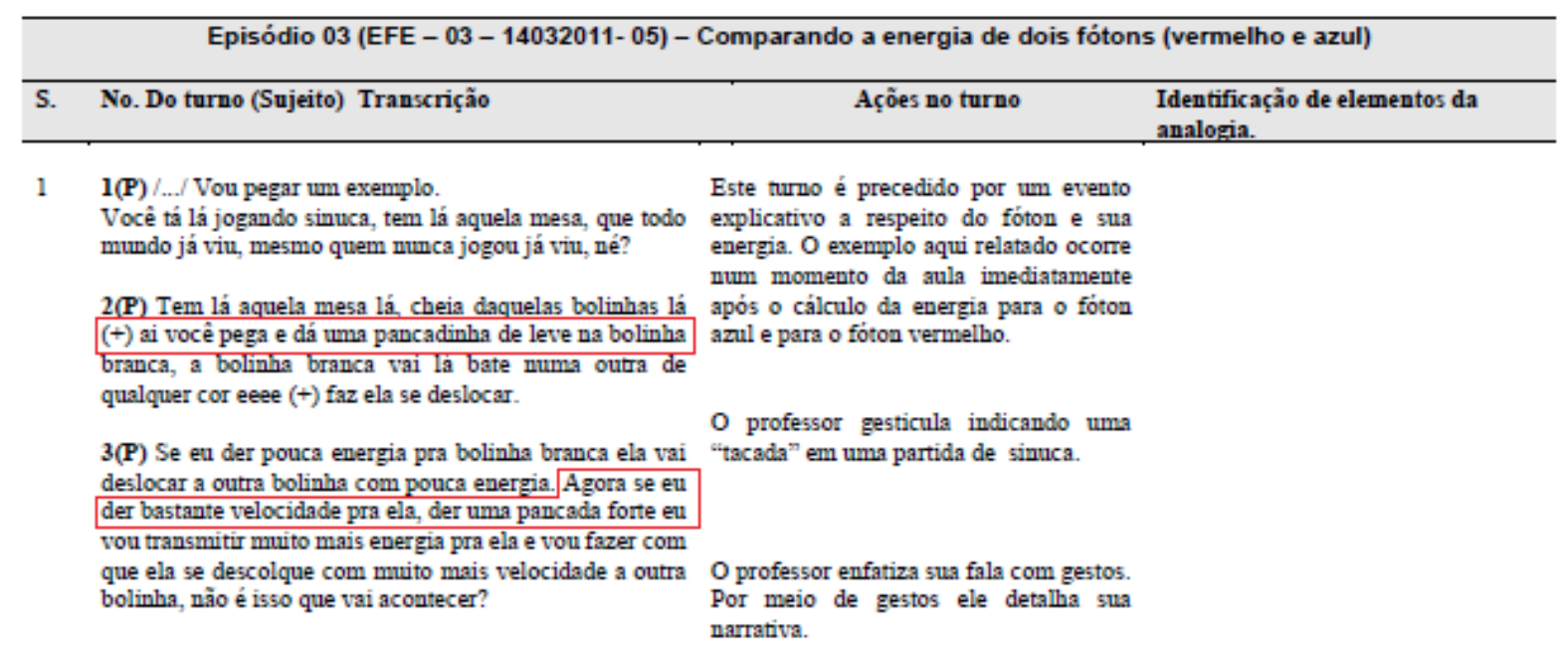

Figura 7.3 - Fragmento do episódio 03

Destacamos na Figura 7.3 elementos na narrativa do professor que mostram a falta de certo rigor com os conceitos físicos envolvidos. Entretanto, nossa observação não coloca em questão a adequação da aplicação dos termos, mas indica que as ações prévias relacionadas à atividade em questão são classificadas como "Sincrônicas à ação de uso", pois, mesmo estando presentes no planejamento do professor (podendo ser esse formal ou não), os elementos da analogia presente no referido episódio são considerados ordinários, na medida em que não fazem menção a uma estrutura didática anterior, mas sim recorrem a elementos de atividades também ordinárias da possível experiência pregressa dos alunos.

Como resultado do panorama geral aqui proposto, apresentamos no Quadro 7.1 as atribuições categoriais, para o episódio 03 , nos três conjuntos de categorias, 
a saber, do nível da analogia, do formato de apresentação, e indicações de ações prévias.

Quadro 7.1 - Classificação em categorias do episódio 03

\begin{tabular}{lll}
\hline \hline & Episódio 03 - EFE - Analogia do jogo de sinuca \\
\hline \hline Nível da analogia & Mecânica & $\begin{array}{l}\text { Relação estrutural particular entre } \\
\text { o análogo e o alvo. }\end{array}$ \\
Formato de apresentação & Verbal-Representativo & $\begin{array}{l}\text { Narrativa reforçada com } \\
\text { esquemas pictóricos do quadro. }\end{array}$ \\
Indicações de ações prévias & Sincrônica à ação de uso & $\begin{array}{l}\text { Ação prevista e baseada na } \\
\text { experiência ordinária dos alunos. }\end{array}$ \\
\hline
\end{tabular}

Apesar de sugerirmos, ao final, a construção de quadros semelhantes a cada episódio analisado em nosso ensaio, o desenvolvimento do presente capítulo se dará a partir da análise dos episódios dentro de cada um dos três conjuntos de categorias. Ou seja, a fim de explorarmos detalhadamente cada grupo categorial, todo nosso material empírico será inicialmente analisado sob a perspectiva do "Nível da analogia", em seguida quanto ao "Formato de apresentação" e por último quanto às “Indicações de ações prévias”.

\subsection{As analogias em nível de elaboração}

Identificamos, através de nossa revisão bibliográfica, que pensar na possibilidade de "tipificar" analogias inseridas em atividades didáticas não é novidade. No entanto, na tentativa de colaborar com pesquisas anteriores, e baseados em nossas reflexões teóricas a respeito do papel das analogias nos campos da psicologia cognitiva e da epistemologia da ciência, lançamos mão das categorias elaboradas na presente tese a fim de olhar para um conjunto de aulas voltadas a temas de física quântica, e discutir a incidência de dado nível de analogia nas ações dos professores. Partimos, então, de nossos dados a fim de construir a categorização proposta.

O episódio 01 [ (MAT - 01 - 01042011- 05) - Física Quântica, o que é?] está inserido na aula cujo tema é modelos atômicos. Os turnos retratados no referido 
episódio destacam a intenção do professor de apresentar o caráter discreto presente no modelo atômico de Bohr. Na tentativa de reforçar tal conceito, ele lança mão de uma analogia.

A analogia aqui proposta tem relação de semelhança de forma, uma vez que o professor compara os níveis atômicos de energia aos degraus de uma escada. $\mathrm{Na}$ verdade, o que o professor deseja destacar está ligado à semelhança entre os domínios quanto à noção de descontinuidade. Assim como alguém, ao subir ou descer uma escada, apoia o seu pé em um degrau, e nunca entre dois degraus, os elétrons segundo o modelo de Bohr também só podem ocupar determinados níveis de energia (calculados para cada átomo específico), e não podem assumir valores de energia intermediários. Nisso, então, reside a relação de semelhança da referida analogia.

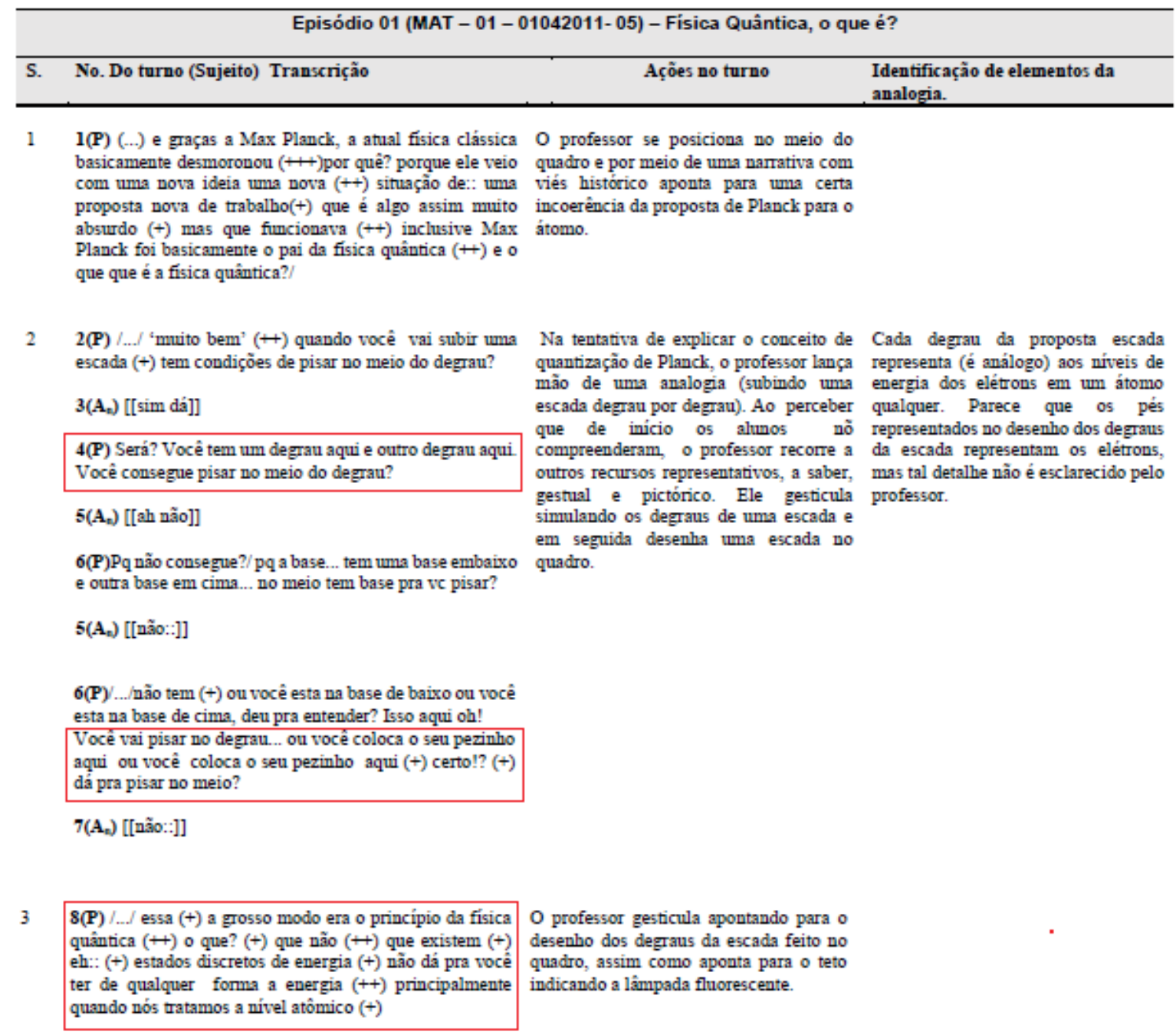

Figura 7.4 - Fragmento do episódio 01 
Destacamos na Figura 7.4 elementos da narrativa do professor que mostram que a semelhança proposta entre o análogo e o alvo é de forma, sendo assim a analogia presente no episódio 01 pertence à categoria "Figurativa".

No episódio 02 [(MAT - 02 - 11032011- 05) - Instabilidade do átomo de Rutherford], o professor lança mão de um formato particular para apresentar um conjunto de elementos de analogia. Com o auxílio de um lençol, uma bola de ferro e pequenas esferas (bolinhas de gude), ele conta com a ajuda dos alunos a fim de promover um tipo de "teatro-animação". Apesar de cada objeto mencionado representar um elemento do átomo de Rutherford, tal relação de forma não parece estar ligada ao principal objetivo da atividade proposta pelo professor. Na verdade, é através da relação dinâmica entre os objetos (bolinhas girando sobre a superfície do lençol, que é deformado pela presença da bola de ferro colocada em seu centro) que a principal analogia ganha sentido. Na figura 7.5, apresentamos um fragmento do episódio 02 que destaca as primeiras relações de semelhança, as quais seriam classificadas como "Figurativas".

\begin{tabular}{|c|c|c|c|}
\hline \multicolumn{4}{|c|}{ Episódio 02 (MAT - 02 - 11032011- 05) - Instabilidade do átomo de Rutherford } \\
\hline S. & No. Do turno (Sujeito) Transcrição & Ações no turno & Identificação de elementos da analogia. \\
\hline 1 & $\begin{array}{l}\text { 1(P) Eu preciso de platéia, e eu preciso de } \\
\text { auxiliares ... deixa eu pegar um cara bem } \\
\text { forte pra me ajudar. }\end{array}$ & \multirow[t]{2}{*}{$\begin{array}{l}\text { O professor caminha até o final da sala a } \\
\text { fim de pegar o material que será usado na } \\
\text { encenação. }\end{array}$} & \\
\hline & 2(A $\left.A_{1}\right)$ Vai lá Will! & & \\
\hline \multirow[t]{4}{*}{2} & $\begin{array}{l}\text { 3(P) O Nosso núcelo do átomo é um } \\
\text { pouquinho pesado }\end{array}$ & \multirow{4}{*}{$\begin{array}{l}\text { O professor empresta a bola de ferro a } \\
\text { aum alumo que a segura. Em seguida ele a } \\
\text { faz passar aos demais colegas. }\end{array}$} & A bola de ferro é o análogo do núcleo. \\
\hline & $\begin{array}{l}4\left(A_{1}\right) \text { Cara, o moleque está quase caindo } \\
\text { (risos). }\end{array}$ & & \\
\hline & $\begin{array}{l}5(\mathrm{P}) \text { é um pouquinho pesado o nosso } \\
\text { núcleo? } \\
6\left(\mathrm{~A}_{2}\right) \text { O que é isso? }\end{array}$ & & \\
\hline & 7(P) O núcleo do nosso átomo & & $\begin{array}{l}\text { Reforço da analogia (bola de ferro como } \\
\text { análogo do núcleo). }\end{array}$ \\
\hline 3 & $\begin{array}{l}\text { 8(P) Isso aqui va simular o nosso campo } \\
\text { eletrônico, a núvem onde o elétron está. }\end{array}$ & O professor destaca o lençol. & $\begin{array}{l}\text { O lençol é o análogo do que o professor } \\
\text { chama de campo eletrônico. }\end{array}$ \\
\hline
\end{tabular}

Figura 7.5 - Fragmento (a) do episódio 02 
No entanto, como destacamos, tal relação de aparência entre os dois domínios não corresponde à finalidade da presente atividade analógica. É preciso avançar nas sequências de turnos deste episódio a fim de encontrar na narrativa do professor relações que ele busca na tentativa de elucidar as questões por ele planejadas, a saber, problemas ligados ao modelo atômico de Rutherford associados aos conhecimentos vigentes da mecânica e do eletromagnetismo clássicos.

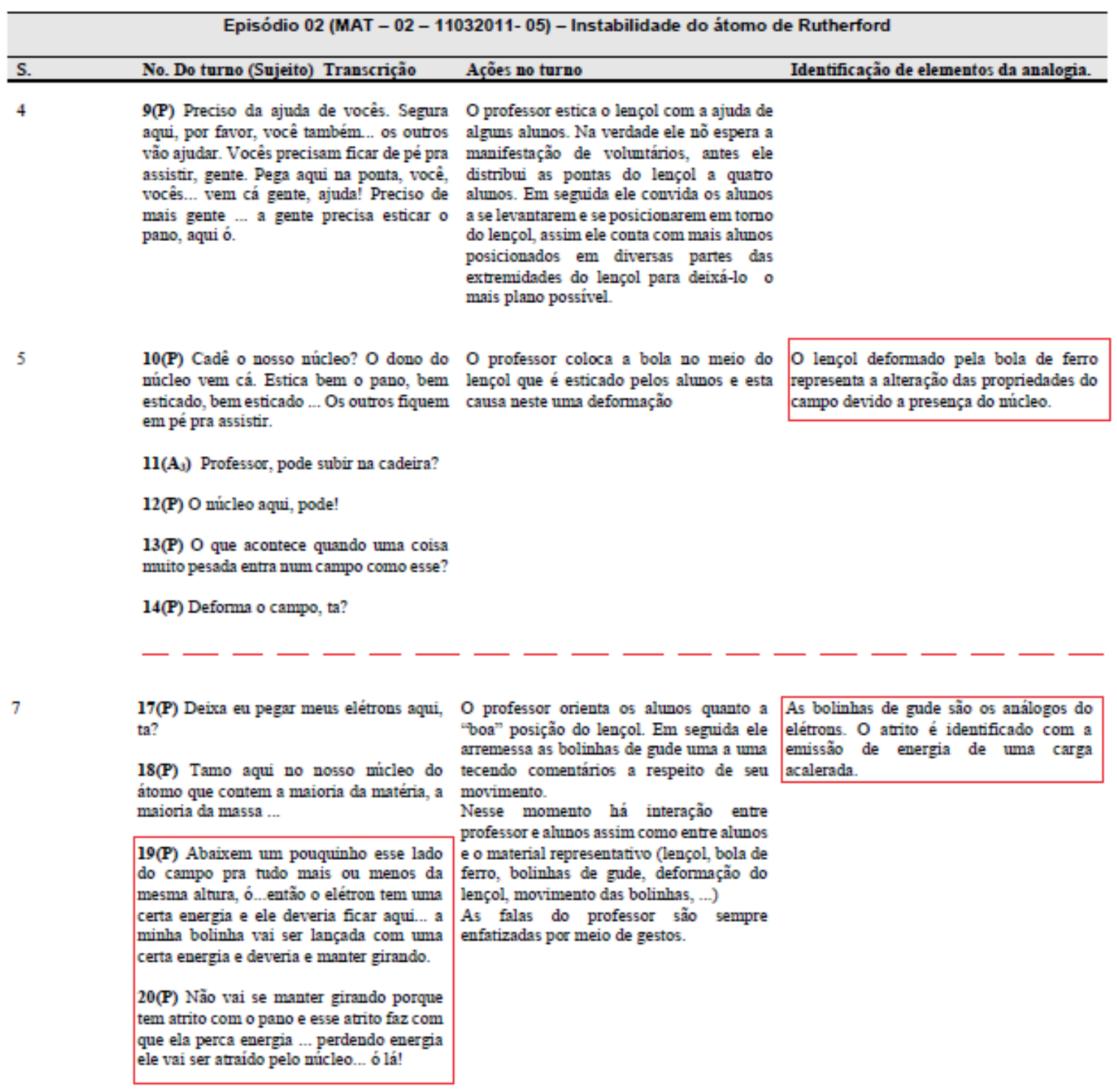

Figura 7.6 - Fragmento (b) do episódio 02 
A partir da análise do fragmento apresentado na Figura 7.6, percebemos relações de semelhança entre 0 análogo e 0 alvo que diferem das analogias grosseiras ou figurativas. Reforçamos que, ainda que existam semelhanças de forma entre os entes da ação analógica, estas não representam o objetivo da atividade em si. Nesse sentido, ao olharmos a atividade como um todo, a analogia inserida no referido evento é classificada como "Mecânica".

Assim como no episódio 02, o episódio 04 [(EFE - 03 - 14032011- 06) Quantização da energia no efeito fotoelétrico] conta com a participação dos alunos. O professor propõe a construção de um jogo de tabuleiro a partir do qual ele busca semelhanças entre a dinâmica do jogo e a quantização da energia.

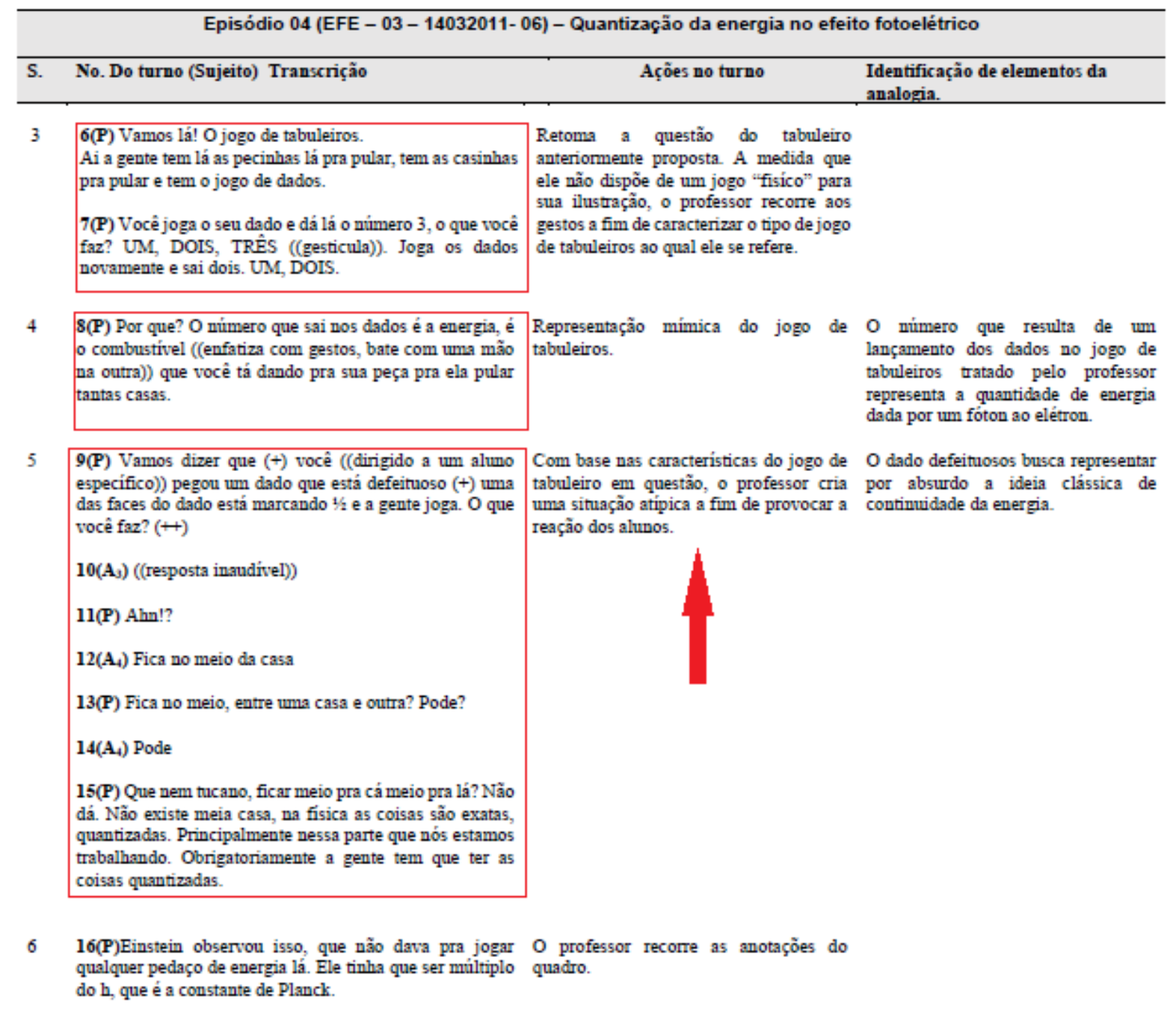

Figura 7.7 - Fragmento (a) do episódio 04 
Destacamos na Figura 7.7 trechos da narrativa do professor que indicam sua intenção didática. Ele sugere, inclusive, a possibilidade do uso de dados que contenham em suas faces números não inteiros, o que corresponde, numa situação atípica, aos jogos de tabuleiros tradicionais. Na verdade, se avançarmos nos turnos do episódio em questão, percebemos outras duas ações analógicas que buscam reforçar esta primeira.

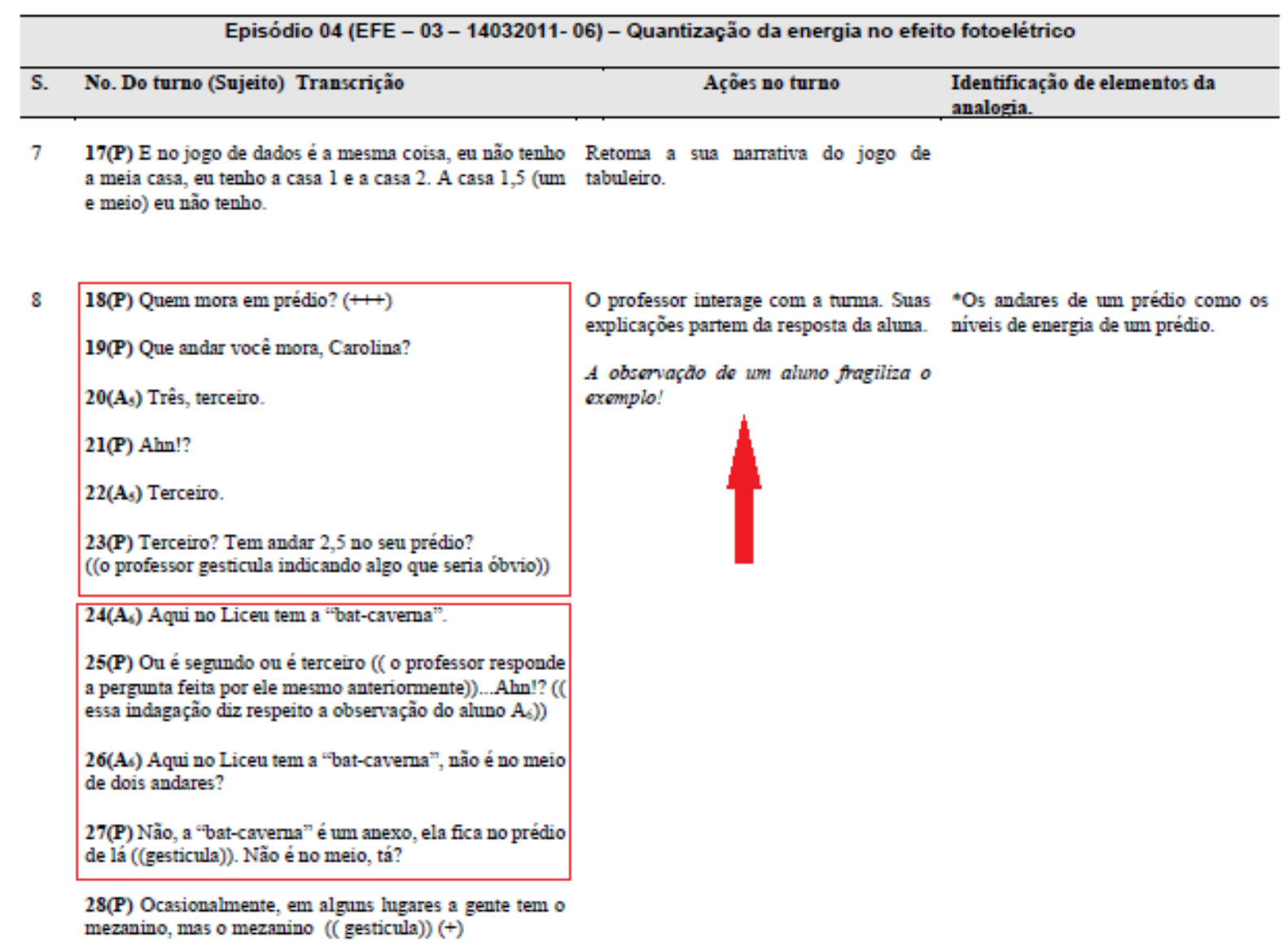

Figura 7.8 - Fragmento (b) do episódio 04

Apresentamos na Figura 7.8 outro fragmento do episódio 04, no qual destacamos trechos da narrativa do professor nos quais ele recorre a outra analogia a fim de reforçar a primeira. No entanto, parece que um contra-exemplo apontado por uma aluna fragiliza a analogia dos níveis de energia quânticos com os andares de um prédio, pois a referida aluna identifica, na estrutura do prédio de seu colégio, um "estágio" intermediário entre dois andares (a "bat-caverna"). 


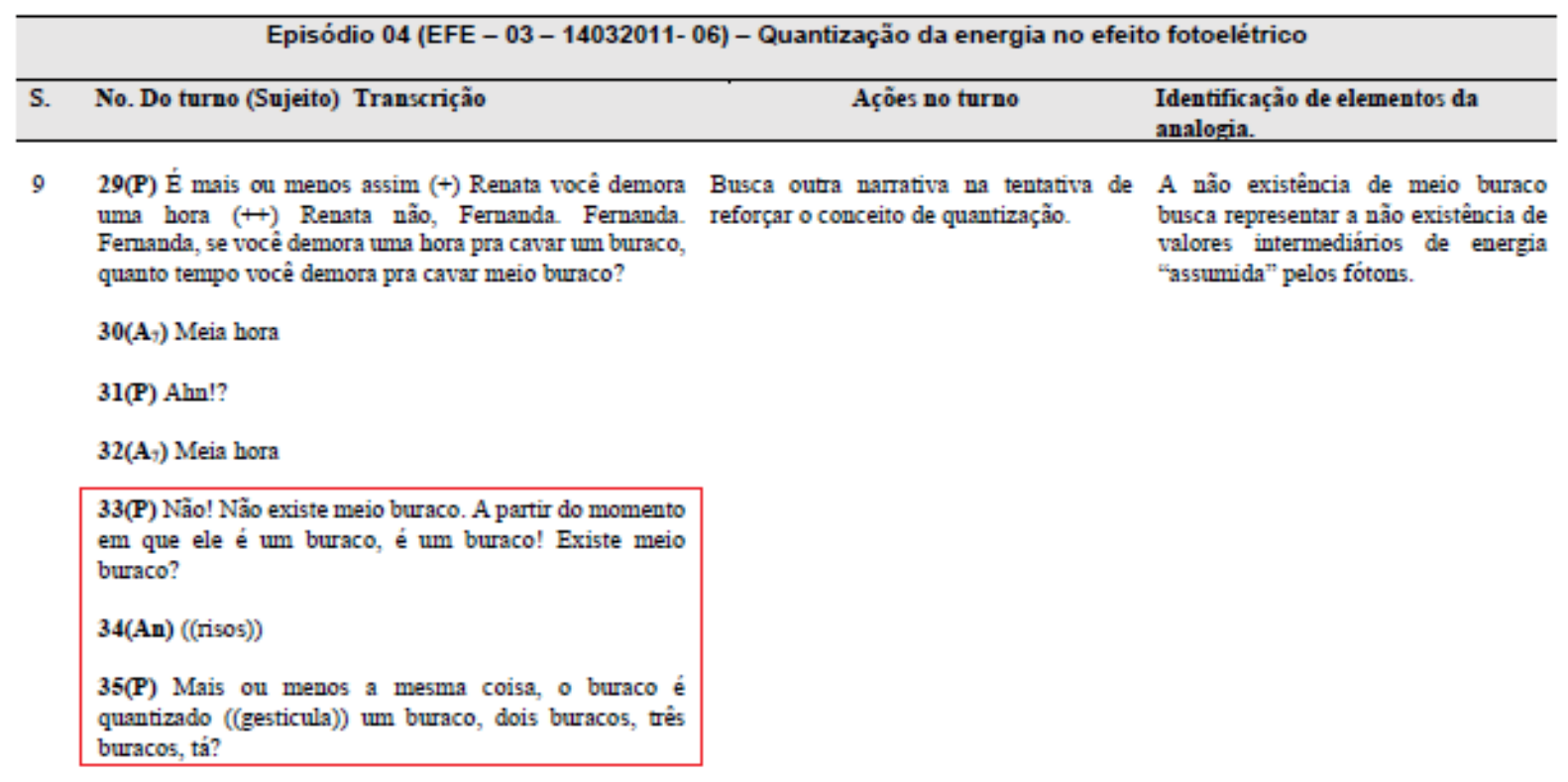

Figura 7.9 - Fragmento (c) do episódio 04

Finalmente, antes de retomar a discussão a respeito do jogo de tabuleiros, e na tentativa de salvar a ideia da analogia dos andares de um prédio, o professor lança mão de uma "analogia-anedota" que destacamos na Figura 7.9. Apesar de a apresentarmos junto às outras analogias, ressaltamos que, pelas suas características, esta seria mais adequadamente classificada como metáfora. Afinal, mesmo que em alguns casos os limites entre analogias e metáforas sejam tênues e, como apresentamos no capítulo 5, alguns autores não façam distinção entre os dois conceitos, a presente "analogia-anedota" apresenta-se com frágeis relações de semelhança com o conceito de quantização, ainda que o professor conclua que "o buraco é quantizado".

Consideramos, assim, que o conjunto de analogias presentes no quarto episódio se encontra no nível de analogias primitivas, sem apresentarem relações de estrutura mais aprimoradas, sendo, assim, classificadas como "Figurativas". 
A respeito do episódio 05 [(MAT - 04 - 14032011- 02) - Energia dos estados quânticos], apresentamos na Figura 7.10 um fragmento do referido episódio a fim de ressaltar que, neste, o professor lança mão de uma ação analógica quase idêntica àquela presente no episódio 04 , a saber, a analogia dos andares de um prédio.

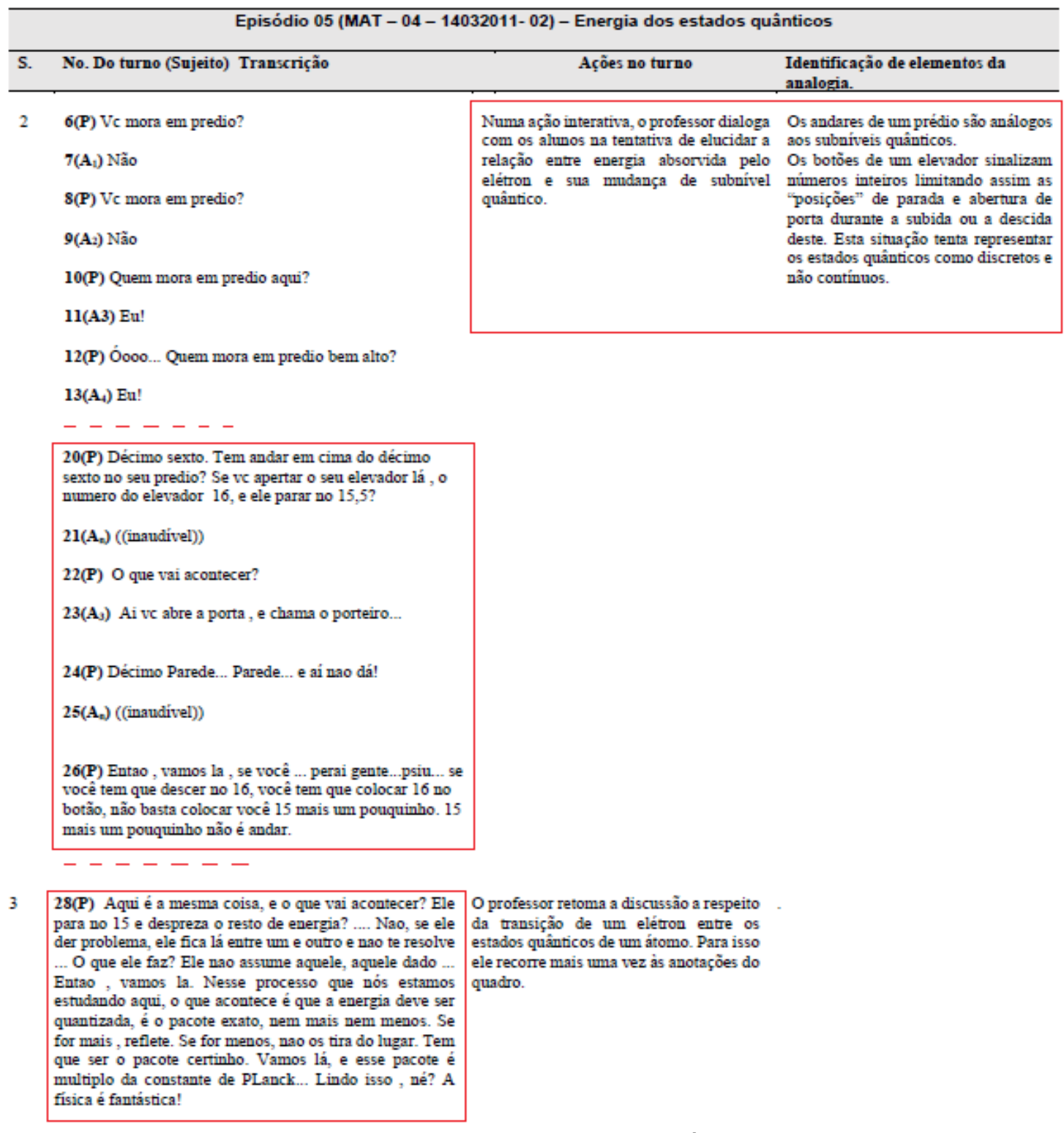

Figura 7.10 - Fragmento do episódio 05

Ainda que percebamos uma discussão mais detalhada no presente episódio, o nível da analogia empregada nesta atividade didática não difere do da anterior, pois, como na outra atividade, a analogia em questão não propõe relações 
estruturais de semelhança entre os dois domínios envolvidos. Desta forma, a analogia presente no episódio 05 também pertence à categoria de analogias "Figurativas".

O episódio 06 [(EFE/ NDL - 06 - 30112012- 01) - O efeito fotoelétrico modelos ondulatório e corpuscular da luz.] se refere a uma aula sobre o efeito fotoelétrico que foi antecedida da apresentação de um simulador do referido fenômeno, manipulado pelos alunos no laboratório de informática. Tendo em vista o contexto da presente aula, o professor procura acentuar a diferença entre os dois modelos fundamentalmente na relação da energia em função da amplitude da onda, em contraste com a energia dos fótons, que dependem da frequência da luz associada.

A manipulação do simulador, sob a coordenação do professor, mostra aos alunos que o aumento da intensidade dos feixes luminosos que incidiam em uma placa composta de dado material não provocava o início do efeito fotoelétrico, para casos em que este não ocorria, e tampouco alterava a energia dos elétrons que eram arrancados da placa em casos em que o efeito já havia iniciado.

Destacamos na Figura 7.11 trechos da narrativa do professor que mostram o encaminhamento do professor no sentido de reforçar o que fora outrora apresentado a respeito da impossibilidade de se explicar o efeito fotoelétrico por meio do modelo ondulatório da luz. 


\begin{tabular}{lll}
\hline \multicolumn{2}{c}{ Episódio 06 (EFE/ NDL - $06-30112012-01)$-O efeito fotoelétrico - modelos ondulatório e corpuscular da luz. } \\
\hline S. No. Do turno (Sujeito) Transcrição & Açoes no turno & $\begin{array}{l}\text { Identificação de elementos da } \\
\text { analogia. }\end{array}$ \\
\hline
\end{tabular}

$1 \quad 1$ (P) Pessoal, no modelo ondulatório qual é a idéia de luz? É que a luz, nessa idéia aqui , a luz pode ter qualquer energia,qualquer um valor possivel de energia, a luz pode ter aqui. Segundo, , a luz, ela é sempre alguma coisa contínua, ela não é quebradinha, né?

O professor usa o quadro a fim de representar a amplitude de uma onda associada a sua intensidade. Em sua representação pictórica ele acentua a diferença de amplitudes entre dois trens

2 (P) Então, quando eu olho para a onda, você percebe ó, de ondas (um com baixo o outro com alto o tempo inteiro ela tem um valor, e esse valor, ele é contínuo, ele não é, não é dividido né? Então, quando você pensa no modelo ondulatório, você tem esse tipo de representação pra luz.

3 (P) Só que ai, pelo efeito fotoelétrico a gente percebeu o seguinte: que não dá para usar esse modelo para explicar o efeito fotoelétrico, por que? Porque quando você pensa nesse modelo, a gente sempre, na onda assim: se você colocar uma intensidade maior, lembra que a intensidade tem a ver com o tamanho da onda né?

4 (P) Então por exemplo, isso daqui é uma luz de baixa intensidade. $\mathrm{O}$ que que seria uma luz de alta intensidade pensando nesse modelo? Seria alguma coisa assim ó ó.((professor desenha no quadro)) Isso aqui é alta intensidade ((professor desenha no quadro)), isso aqui é baixo intensidade.

$4 \quad 17(\mathrm{P})$ Como é que é o nome desse modelo? Esse modelo aqui, que substitui esse modelo para explicar o efeito fotoelétrico, esse é o chamado, modelo fótocorpuslar.

18 (P) Pessoal, por que foi usado a palavara corcuspular? Tem a ver com corcúspulo, é como se fosse uma coisa, é como se a luz não fosse fazer uma coisa contínua né, ela fosse dividida em pequenas partículas.

19 (P) Pessoal, quanto vale cada par.., qual é a energia de cada partícula dessa luz?Cada bolinhas dessa que eu tô usando para representar a luz, se é que isso daqui de fato é uma bolinha, né? Ó, cada fóton desse tem essa energia ó (( escreve no quadro)), a energia de um fóton é uma constante a natureza que é o $\mathrm{h}$ multiplicado pela freqüência , então cada partícula dessa tem essa energia aqui ó ((completa a anotação no quadro)).

20 (P) E aí o que você percebe? Que a energia não depende da amplitude ó, não depende da intensidade, a energia depende da frequiência, está ligado a isso. Dependendo dessa frequêencia, eu vou conseguir arrancar elétrons do elétrons ou não.

21 (P) Então, aqui é uma coisa contínua, aqui ela não é contínua. Aqui a energia só pode ter determinados valores ó. Você percebe quando você faz essa ponta, a energia não tem qualquer valor, ela só vai ter valores bem definidos, que vai ser exatamente a multiplicação do $\mathrm{h}$ ( que é uma constante da natureza) multiplicado pelo freqüência.

A ação do professor é discursiva e conclusiva. No entanto, como ferramenta auxiliar, ele usa as representações pictóricas realizadas anteriormente e reforça agora com representações matemáticas da equação da energia de um fóton $(E=h . v)$ a partir da qual destaca que a energia não depende da amplitude, mas sim da frequência da luz em questão.

Figura 7.11 - Fragmento (a) do episódio 06

A fim de reforçar o contraste entre o conceito de energia como grandeza contínua com o conceito da mesma grandeza física como discreta, o professor lança mão de uma analogia. A Figura 7.12 apresenta outro fragmento do episódio 06 no qual destacamos alguns turnos que mostram a mudança de tema da narrativa a 
partir da qual o professor compara a ideia de continuidade e descontinuidade presente no ato de observar a chuva de longe ou de perto com ideia primeira das ondas luminosas, e esta das partículas de luz sugerida por Einstein em 1905.

\begin{tabular}{l}
\hline Episódio 06 (EFE/ NDL - 06 - 30112012- 01) -O efeito fotoelétrico - modelos ondulatório e corpuscular da luz. \\
\hline S. No. Do turno (Sujeito) Transcrição
\end{tabular}

12 (P) Toda vez que esses fótons, que são partículas aqui, ó, elas batem no metal, cada fóton desse ó, cada partícula dessa, dá toda energia dela para o elétron do metal, e aí você consegue arrancar os elétrons do metal.

13 (P) Aqui ... qual é a grande diferença daqui para essa representação? Aqui a luz é como se fosse uma coisa continua, e ela pode ter qualquer valor de energia.

14 (P) Aqui nessa representação já muda completamente, concorda? Aqui por exemplo, a luz não é mais uma coisa contínua , é como se fosse uma coisa granulada.

$3 \quad 15$ (P) Pessoal, vamos pensar nas gotas de chuva, se você olhar a chuva caindo de longe, ela não tem esse aspecto aqui ó ((desenha no quadro)), parece um coisa contínua? Parece eu não tem divisão, a chuva quando tá caindo. Mas se a gente fosse capaz de olhar a luz...a chuva de um jeito mais Próximo, você percebe que a chuva, ela não é continua desse jeito, ela é formada de pequenas gotículas.
A fim de reforçar o contraste entre os As gotas da chuva representam o conceitos de "coisas discretas" $\mathrm{x}$ "coisas carater discreto da luz.

continuas", o professor lança mão de uma A impressão de continuidade da analogia que é apresentada em sua chuva representa a "falsa" impressão narrativa e reforçada por representações do carater contínuo da luz. pictóricas no quadro.

\begin{abstract}
16 (P) Então aqui ó((aponta pro desenho no quadro)), é a representação que a gente tem hoje de como seria a luz, a luz não é uma coisa contínua, a luz é formada por partículas, essas partículas o Einstein né,acabou batizando de fótons, e toda vez que esses fótons batem aqui no metal, dependendo da energia que esses fótons tiverem, você consegue arrancar elétrons, essa é a idéia.
\end{abstract}

Figura 7.12 - Fragmento (a) do episódio 06

Esta é uma analogia que recorre unicamente a semelhanças figurativas de ondas luminosas e fótons com os pingos da chuva e sua aparente continuidade. Inferimos, então, que a presente atividade analógica é classificada como mais um exemplo de analogia "Figurativa".

O episódio 07 [Episódio 07 (NDL - 07 - 30112012- 04) - Interpretação dualista realista para o experimento monofotônico] é correspondente a uma aula na qual o professor apresenta e discute quatro das principais interpretações da Mecânica Quântica (MQ) e toma como base alguns resultados do experimento realizado com o interferômetro de Mach-Zehnder (IMZ). Tal discussão com os alunos 
foi precedida da montagem do interferômetro em sala de aula, assim como da manipulação do simulador do IMZ sob a coordenação do professor.

Após apresentar as interpretações ondulatória e corpuscular da $M Q, 0$ professor encaminha a discussão, tomando sempre como base alguns resultados do IMZ, a fim de apresentar uma terceira interpretação, a saber, a dualista realista. Como ação didática, o professor lança mão da analogia do surfista, também presente em Pessoa Jr (2003b).

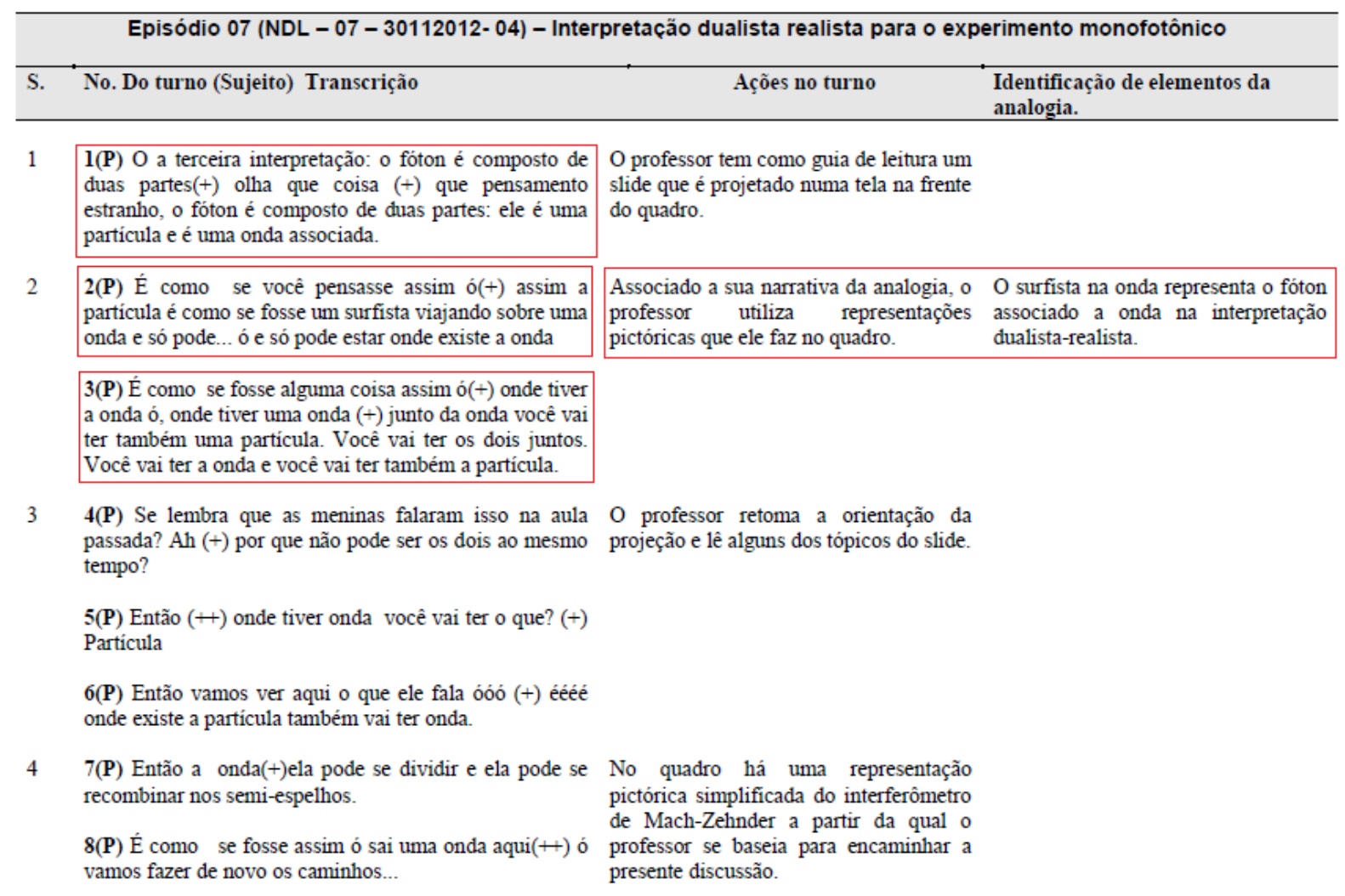

Figura 7.13 - Fragmento do episódio 07

A representação do fóton por um surfista deixa clara a relação de semelhança figurativa da presente analogia. É bem verdade que tal analogia busca, a partir dos resultados de experiências com o IMZ, atribuir um "status" realista aos quanta de luz de Einstein, sem perder a coerência com os padrões de interferência que aparecem em determinados arranjos experimentais do referido interferômetro. Ainda assim, como nosso intuito no presente ensaio é o de propor certa categorização das 
analogias que aparecem no conjunto de aulas aqui analisadas, a referida ação analógica pertence à categoria "Figurativa".

O último episódio que será analisado nesse grupo categorial (quanto ao nível das analogias) está inserido num contexto onde o tema central da aula é o efeito fotoelétrico. No episódio 08 [(EFE - 08 - 22112012- 04) - Efeito fotoelétrico], o professor busca por meio de uma analogia mostrar como as previsões do modelo ondulatório da luz para efeito fotoelétrico apresentam incoerências com o que é observado na experiência. É através da narrativa da situação física de uma ponte que é acometida por rajadas de vento que o professor propõe a sua analogia. A Figura 7.14 mostra turnos da ação analógica.

\begin{tabular}{|c|c|c|c|}
\hline \multicolumn{4}{|c|}{ Episódio 08 (EFE - $08-22112012-04$ ) - Efeito fotoelétrico } \\
\hline S. & No. Do turno (Sujeito) Transcrição & Ações no turno & $\begin{array}{l}\text { Identificação de elementos da } \\
\text { analogia. }\end{array}$ \\
\hline 1 & $\begin{array}{l}\text { 1(P) Uma onda bate no material ela consegue ter uma } \\
\text { interferência com esse material( }+ \text { ) ela tem uma relação } \\
\text { com esse material tá? Uma interação com esse material. }\end{array}$ & $\begin{array}{l}\text { O professor buscava evidenciar que a } \\
\text { partir do modelo ondulatório da luz não } \\
\text { se conseguia explica o efeito fotoelétrico. }\end{array}$ & \\
\hline 2 & $\begin{array}{l}\text { 2(P) Por exemplo }(+) \text { no caso da ponte qua a gente viu a } \\
\text { ponte ((gestos)) como é que você explica aquilo lá? } \\
3(\mathbf{P}) \text { A onda vem }((\text { gestos }))(+) \text { o vento vem e aí a ponte } \\
\text { começa a balançar. Quando a ponte tá balançando }(+) \\
\text { quando ela tá voltando pro movimento dela lá }(+) \text { pra }\end{array}$ & $\begin{array}{l}\text { O professor inicia uma narrativa de uma } \\
\text { situação na qual uma ponte desaba sob a } \\
\text { ação do vento. Ele buscou a analogia da } \\
\text { ponte a fim de contrastar com as } \\
\text { previsões do experimento relativo ao } \\
\text { efeito fotoelétrico. }\end{array}$ & $\begin{array}{l}\text { A ação do vento sobre a ponte é o } \\
\text { análogo da ação da luz sobre uma } \\
\text { placa metálica. }\end{array}$ \\
\hline & $\begin{array}{l}\text { parar }(+) \text { áá }(++) \text { o ar vem }(+) \text { né o vento }(+) \text { a onda do ar } \\
\text { bate e aumenta a amplitude e ai ela vem }(+) \text { quando ela tá } \\
\text { voltando bate de novo e ai ela vai aumentando a } \\
\text { amplitude }(+) \text { né? A ponte }(++) \text { até uma hora que ela cai. }\end{array}$ & & \\
\hline
\end{tabular}

Figura 7.14 - Fragmento (a) do episódio 08

Questões associadas à "intensidade" do vento e o tempo decorrido até uma possível destruição da ponte são incorporadas à discussão. A interação "vento $x$ ponte" é destacada no início da narrativa, e esta busca construir relação de semelhança da interação dos fótons com os elétrons da placa metálica presente no experimento virtual apresentado pelo professor anteriormente. A Figura 7.15 destaca elementos do episódio 08 que sugerem a construção analógica escolhida pelo professor. 


\begin{tabular}{llcccc}
\hline S. No. Do turno (Sujeito) Transcrição no turno & $\begin{array}{l}\text { Identificação de elementos da } \\
\text { analogia. }\end{array}$ \\
\hline
\end{tabular}

4(P) Isso a onda explica, o modelo ondulatório explica (+) é um negócio super básico né? $(+)$ vai empurrando(+) vai empurrando e chega uma hora que começa $(++)$ ah ela balança também $(+)$ você vai empurrando vai empurrando vai aumentando a amplitude e tal (+) tem uma hora que não aguenta (+) não se sustenta mais e cai.

5(P) O problema é $(+)$ esse tipo de explicação demora (+) esse tipo de efeito demora muito(+) então pra cair a ponte demora.

3

8(P) Começam na verdade a desmanchar a desmanchar seria mais ou menos isso (+) entre aspas tá? ((reforça com gestos indicando aspas)) desmanchar (++) e aí começa a sair elétrons $(++)$ e ai $(+)$ só que por um longo tempo.

9(P) Ai a gente percebe que quando bate a luz ((gestos)) na hora sai o elétron (+) esse é o problema.

10(P) Outro problema é você aumentar a intensidade luminosa (+) então você aumenta ali aaa $(++)$ coloca uma luz mais forte entre aspas $(+)$ coloca uma luz mais clara $(+)$ deveria $(+++)$
A partir da analogia da ponte o professor retoma a discussão do efeito fotoelétrico. Nesse momento ele inclui $o$ fator intervalo de tempo para $o$ inicio do fenômeno.
11(P) É como se fosse um vento mais forte

12(P) $(+)$ deveria ééé $(++) \circ$ efeito ser mais imediato ainda

13(P) Só que se você coloca a luz mais intensa(+) num (+) não acontece isso

14(P) Só vai mudar quando você muda a frequência $(+)$ quando você muda a cor da luz (+) quando você muda o comprimento de onda.

15(P) Então pra uns tipos de luz dá o efeito fotoelétrico $(+)$ pra outros tipos não dá $(+)$ e aí era um problema também.
Retoma rapidamente a analogia da ponte e reforça a questão do fator intervalo de tempo no referido efeito.

Figura 7.15 - Fragmento (b) do episódio 08

É por meio dos fenômenos concernentes à situação física do análogo que o professor busca aproximação com a situação alvo (o efeito fotoelétrico). Não se propõem relações de semelhança de forma na presente analogia, antes é por meio dos conceitos físicos envolvidos na situação do análogo (amplitude, intervalo de tempo) que o professor propõe sua analogia. Sendo assim, a presente atividade analógica é classificada como "Mecânica". 


\subsection{As analogias em seu formato de apresentação}

Nesta seção pretendemos olhar os episódios selecionados sob a perspectiva do formato de apresentação. Tal grupo de categorias surge, fundamentalmente, da síntese entre a dimensão epistemológica e a dimensão didática presente em nossa análise teórica. Destacamos aqui o trabalho de Curtis e Reigeluth (1984), que se apresentou como elemento importante de nossa síntese, uma vez que este apresenta um conjunto de categorias a partir das quais nos pautamos a fim de estabelecer as nossas. Dentre os critérios de análise de apresentação de analogias em livros didáticos, o "Formato de Apresentação" também aparece no referido trabalho. Entretanto, as categorias a ele vinculadas são: "Verbal" e "Pictóricoverbal".

Quadro 7.2 - Formato de Apresentação em Curtis e Reigeluth (1984)

\begin{tabular}{|l|l|l|}
\hline Critério & Categorias & \begin{tabular}{l} 
Descrição \\
\hline \multirow{3}{*}{ Formato de apresentação }
\end{tabular} \\
\cline { 2 - 3 } & Verbal & $\begin{array}{l}\text { A analogia é apresentada } \\
\text { pelo uso exclusivo de } \\
\text { palavras (textual ou oral) }\end{array}$ \\
\cline { 2 - 3 } & Pictórico-verbal & $\begin{array}{l}\text { A analogia é reforçada por } \\
\text { figuras }\end{array}$ \\
\hline
\end{tabular}

O Quadro 7.2 apresenta as categorias referente ao critério "Formato de apresentação", assim como as respectivas descrições. É importante destacar que o referido trabalho parte de analogias presentes em livros didáticos de ciências. Tendo em conta as particularidades de seu contexto, os autores encontraram, no conjunto de 216 analogias presentes em 26 livros didáticos, fundamentalmente as duas categorias supracitadas. Contudo, nosso contexto difere deste na medida em que entendemos que nas ações dos professores, por serem "sincrônicas" e com maior possibilidade de improviso e interação, as analogias podem ser apresentadas de formas mais diversas. A proposta de ampliar as categorias do referido critério se deu a partir de nossos dados assim como foram conjugados, obviamente, com nossa perspectiva teórica. Se, por um lado, nossos dados nos apresentaram episódios em que foram encaminhadas atividades analógicas que sugeriram a referida ampliação 
das categorias, por outro lado, a perspectiva das analogias matemáticas também contribuiu com a elaboração de nosso quadro categorial ligado ao "Formato de Apresentação". Reapresentamos no Quadro 7.3 as categorias elaboradas e utilizadas na presente tese.

Quadro 7.3 - "Novas" categorias quanto ao Formato de Apresentação

\begin{tabular}{ll}
\hline \hline \multicolumn{1}{c}{ Formato de Apresentação } \\
\hline Verbal & $\begin{array}{l}\text { A analogia é apresentada pelo uso exclusivo de palavras (textual ou } \\
\text { verbal) numa perspectiva narrativa de fatos. }\end{array}$ \\
Verbal-Representativo & $\begin{array}{l}\text { Semelhante ao formato verbal, esta categoria reúne ações de ordem } \\
\text { narrativa. No entanto, no intuito de enfatizar a narrativa, esta é } \\
\text { reforçada por representações pictóricas, cênicas ou "plásticas". }\end{array}$ \\
Matemático- & $\begin{array}{l}\text { Neste formato, o professor geralmente recorre a estruturas } \\
\text { matemáticas (geométricas ou algébricas) a partir das quais ele } \\
\text { destaca um tipo de semelhança estrutural sem compromisso } \\
\text { ontológico entre as entidades físicas representadas }\end{array}$
\end{tabular}

Portanto, a partir de nossas categorias, iniciamos a classificação de nossos episódios no critério discutido nesta seção. A referida classificação conta as descrições de cada episódio, mas sobretudo com as ações do turno. Como se trata dos mesmos episódios analisados na seção 6.1, algumas questões aqui reaparecem. No entanto, a fim de evitar o excesso de repetições, buscamos destacar apenas elementos que justifiquem a categoria da ação analógica em questão.

No episódio 01 [(MAT - 01 - 01042011- 05) - Física Quântica, o que é?], encontramos uma ação analógica do professor que busca enfatizar o caráter discreto da energia assumida pelos elétrons em contraste com a concepção de continuidade inerente ao referido conceito presente nas analises de fenômenos clássicos. 


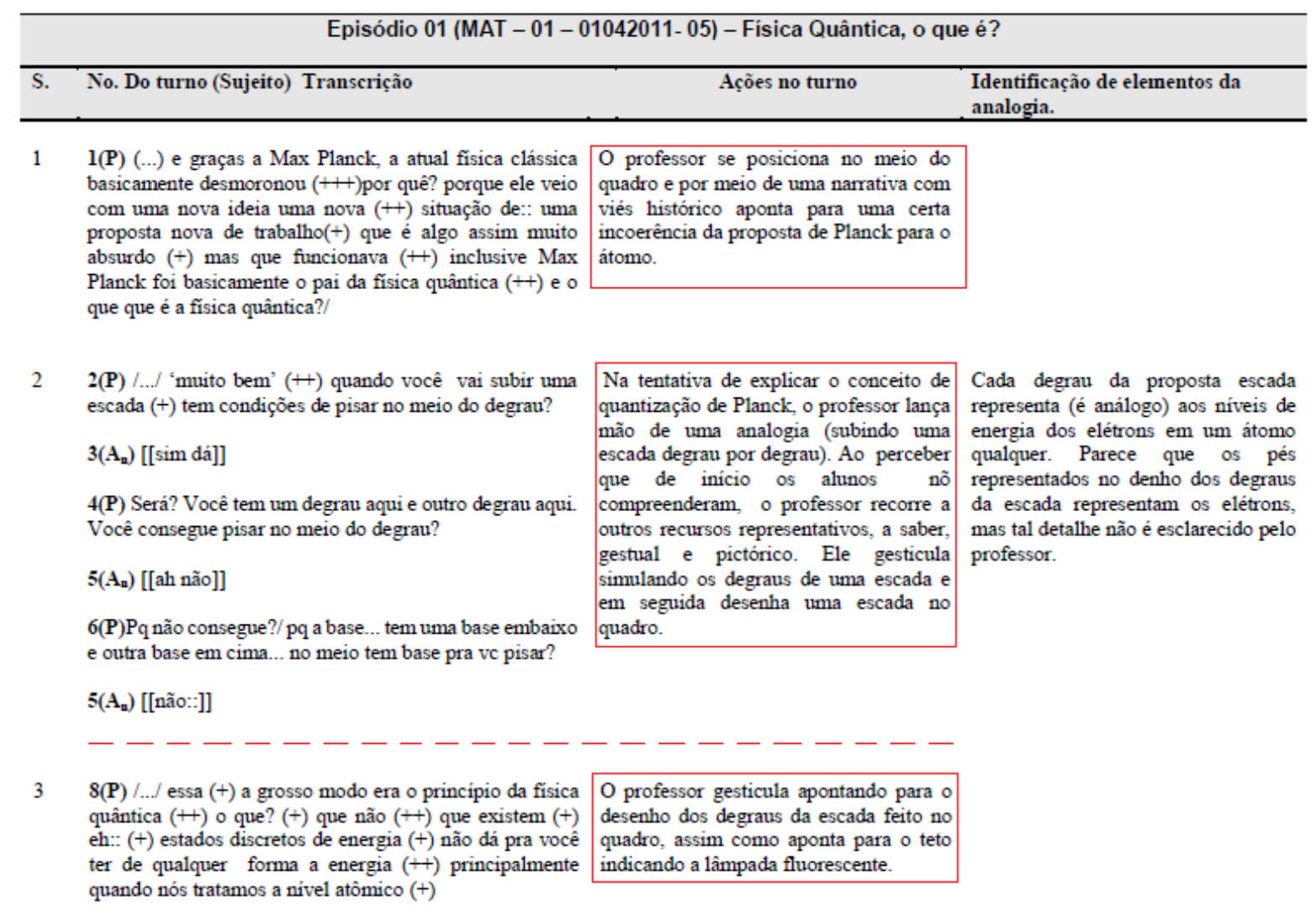

Figura 7.16 - Fragmento (2) do episódio 01

A Figura 7.16 apresenta ações de turno nas quais encontramos elementos que nos permitem fazer as inferências seguintes a respeito do formato de apresentação em questão. Ao lançar mão da analogia figurativa dos degraus de uma escada, o professor não se limita à sua narrativa, antes ele recorre a ferramentas de representação de ordem pictórica e gestual. No entanto, as representações pictóricas (desenhos feitos por ele no quadro) estão restritas ao ato de tornar "mais visuais" os detalhes de sua narrativa. Portanto, a atividade analógica presente no episódio 01 tem formato de apresentação "Verbal-representativo".

No grupo de categorias analisados nesta seção, o episódio 02 [Episódio 02 (MAT - 02 - 11032011- 05) - Instabilidade do átomo de Rutherford] se destaca uma vez que percebemos aqui um "novo" formato de apresentação de analogias voltadas a atividades didáticas. No presente episódio, o professor escolhe um modo particular para a representação de sua analogia, a saber, ele lança mão de uma encenação da qual os alunos participam indiretamente, afinal os verdadeiros "atores" do "teatro" 
proposto pelo docente são os objetos que representam as entidades do mundo atômico (as bolas de gude, o lençol e a bola de ferro).

Neste caso, a narrativa do professor se dá na apresentação dos elementos, assim como no papel desempenhado por cada um na representação. Em seguida, uma vez iniciada a dinâmica do processo analógico referente a contradições entre a previsão clássica da Mecânica e do Eletromagnetismo, sua narrativa se dá de forma descritiva.

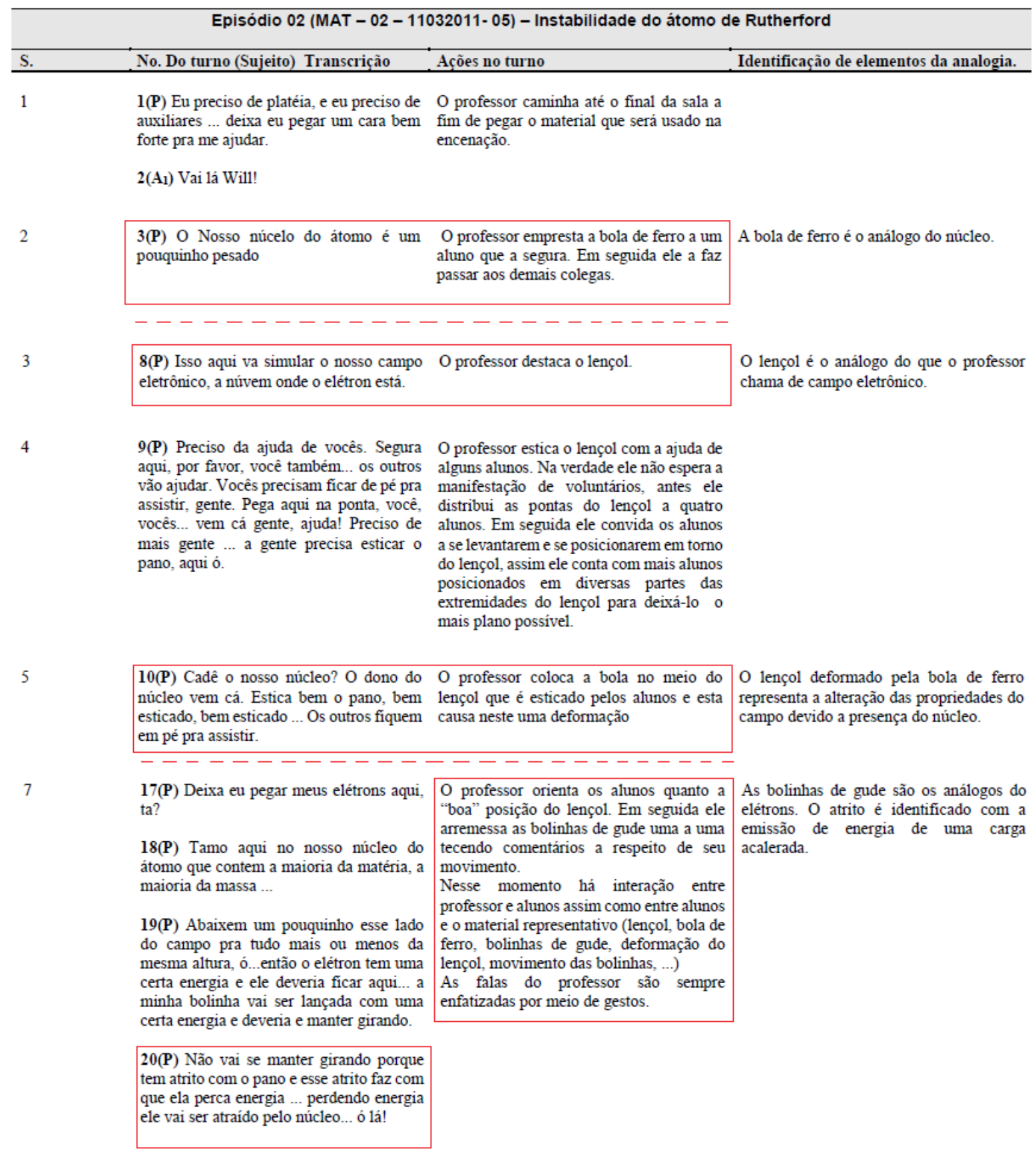

Figura 7.17 - Fragmento (2) do episódio 02 
A Figura 7.17 destaca trechos do episódio 02 nos quais encontramos elementos nas ações do professor que nos permitem atribuir a este episódio o formato "Verbal-Representativo".

No episódio 04 [(EFE - 03 - 14032011- 06) - Quantização da energia no efeito fotoelétrico], como destacamos na seção anterior, a fim de reforçar a ideia de quantização presente na descrição do efeito fotoelétrico, o professor lança mão de uma sequência de analogias. A primeira diz respeito a um jogo de tabuleiros no qual ele busca semelhança no fato de uma pecinha pertencente ao jogo poder ocupar apenas as "casas" disponíveis no tabuleiro. Tal questão é evidenciada pelo fato de o(s) dado(s) envolvido(s) no jogo dispor(em) apenas de números inteiros em suas faces. A fim de complexificar a questão, o professor propõe a existência de dados "defeituosos" e problematiza a nova situação. Destacamos na Figura 7.18 as transcrições assim como as ações dos turnos correspondentes à nossa análise.

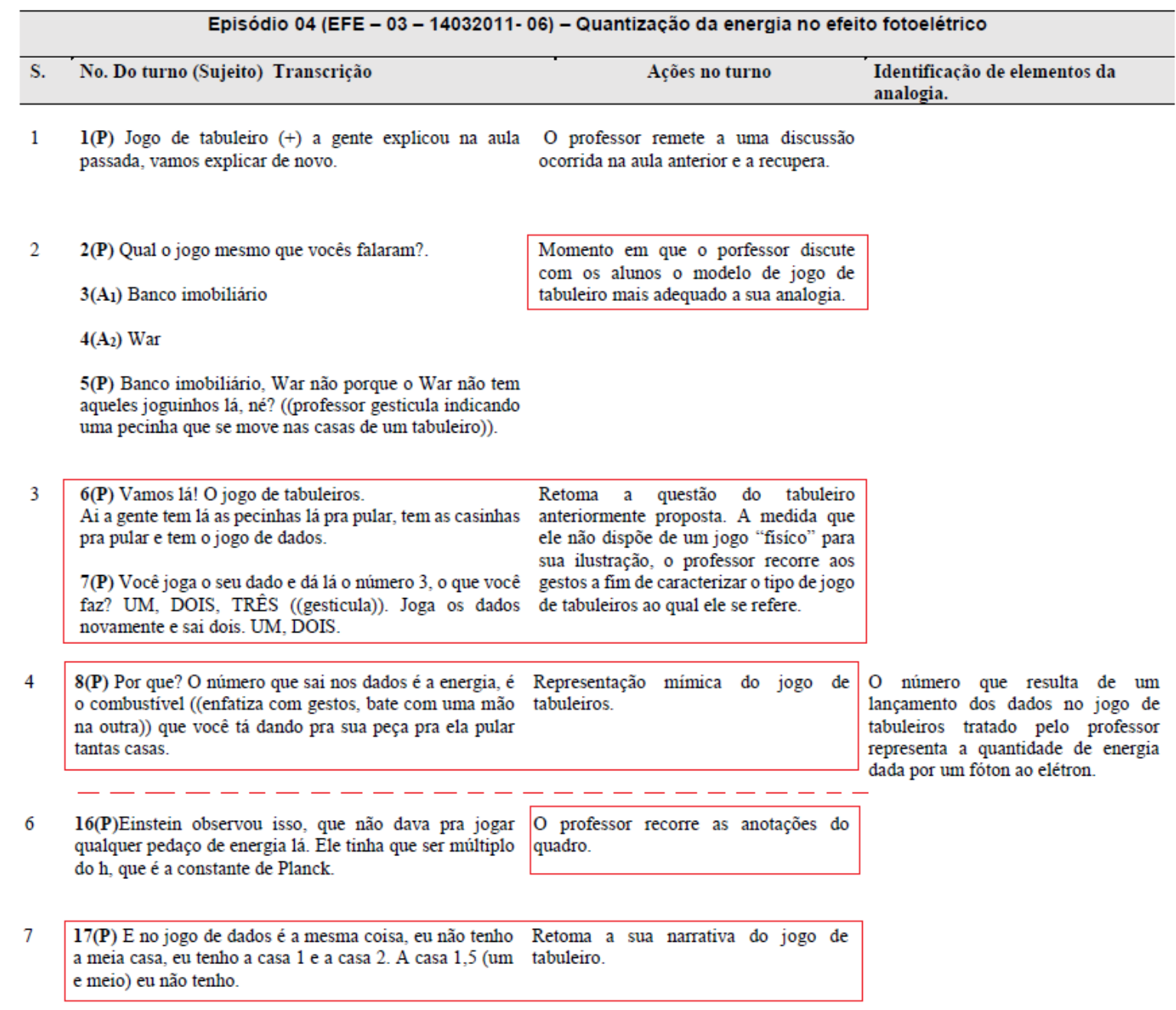

Figura 7.18 - Fragmento (2a) do episódio 04 
Em seguida, antes de concluir sua narrativa a respeito da analogia do jogo de tabuleiros, o professor lança mão de outras duas analogias dentro do mesmo objetivo, a saber, destacar as particularidades da noção de não continuidade presentes no conceito de quantização da energia. Então, o professor lança mão da analogia do elevador de um prédio, e posteriormente usa a "metáfora" de cavar buracos. Ambas as ações visavam reforçar a analogia do jogo de tabuleiros, afinal, antes de concluir, a referida analogia é retomada. A Figura 7.19 destaca fragmentos do episódio.

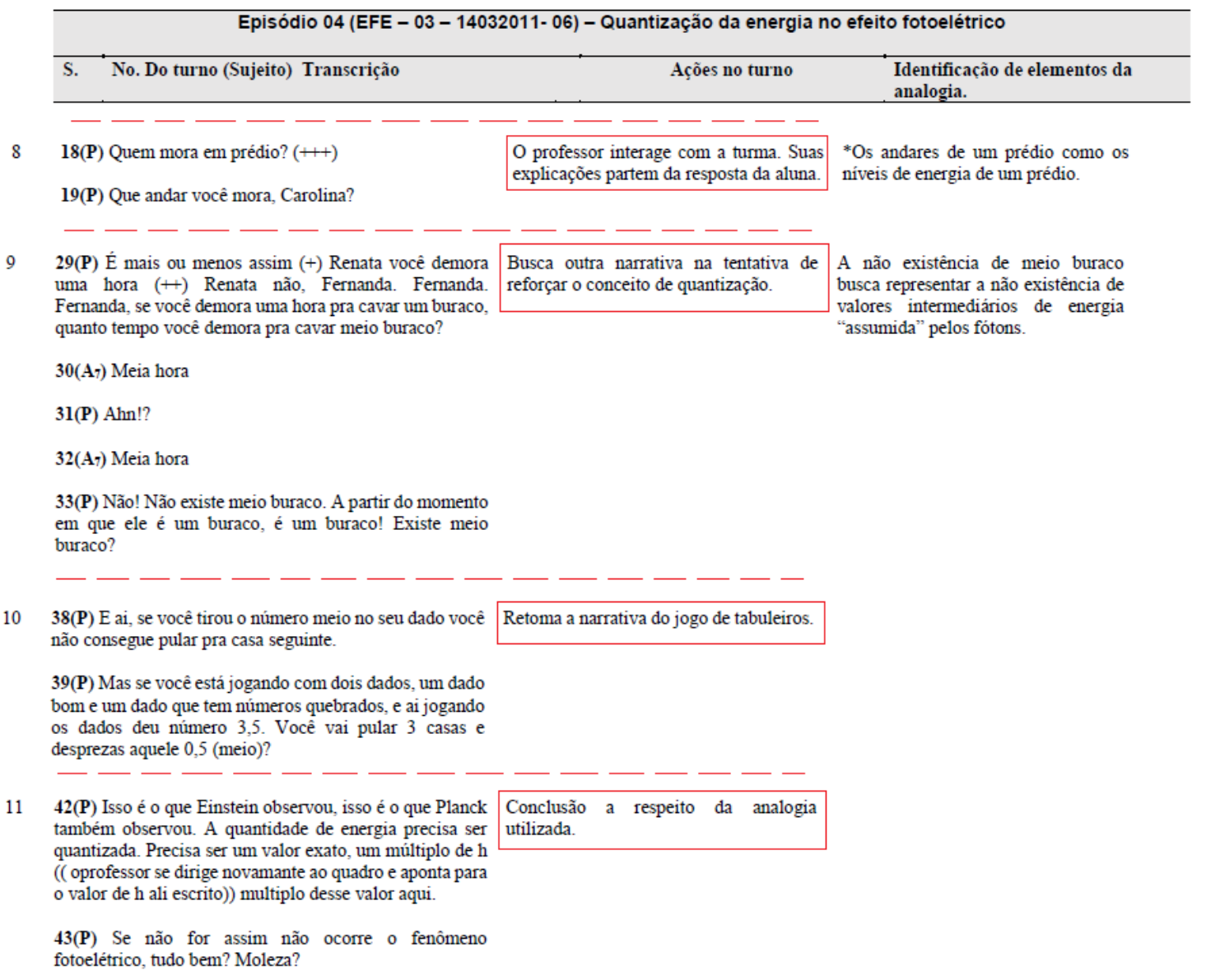

Figura 7.19 - Fragmento (2b) do episódio 04

Em ambos os fragmentos destacados nas Figuras 7.18 e 7.19, percebemos ações do professor exclusivamente narrativas, o que nos permite atribuir a classificação de formato "Verbal" às atividades analógicas presentes no episódio 04. 
Assim como no episódio anterior, o episódio 05 [(MAT - 04 - 14032011- 02) Energia dos estados quânticos] apresenta uma ação analógica que busca semelhança entre o movimento vertical de um elevador, que permite o embarque e desembarque de pessoas apenas em determinados níveis de altura (nos andares do respectivo prédio), e as possíveis transições entre os níveis de energia subatômicos.

A apresentação da analogia supracitada ocorre de forma exclusivamente narrativa. O professor busca, na experiência sensível e "imediata" dos alunos, a referência para sugestão do análogo. A figura 7.20 ilustra o fragmento do episódio em questão, tendo este o formato "Verbal" de apresentação.

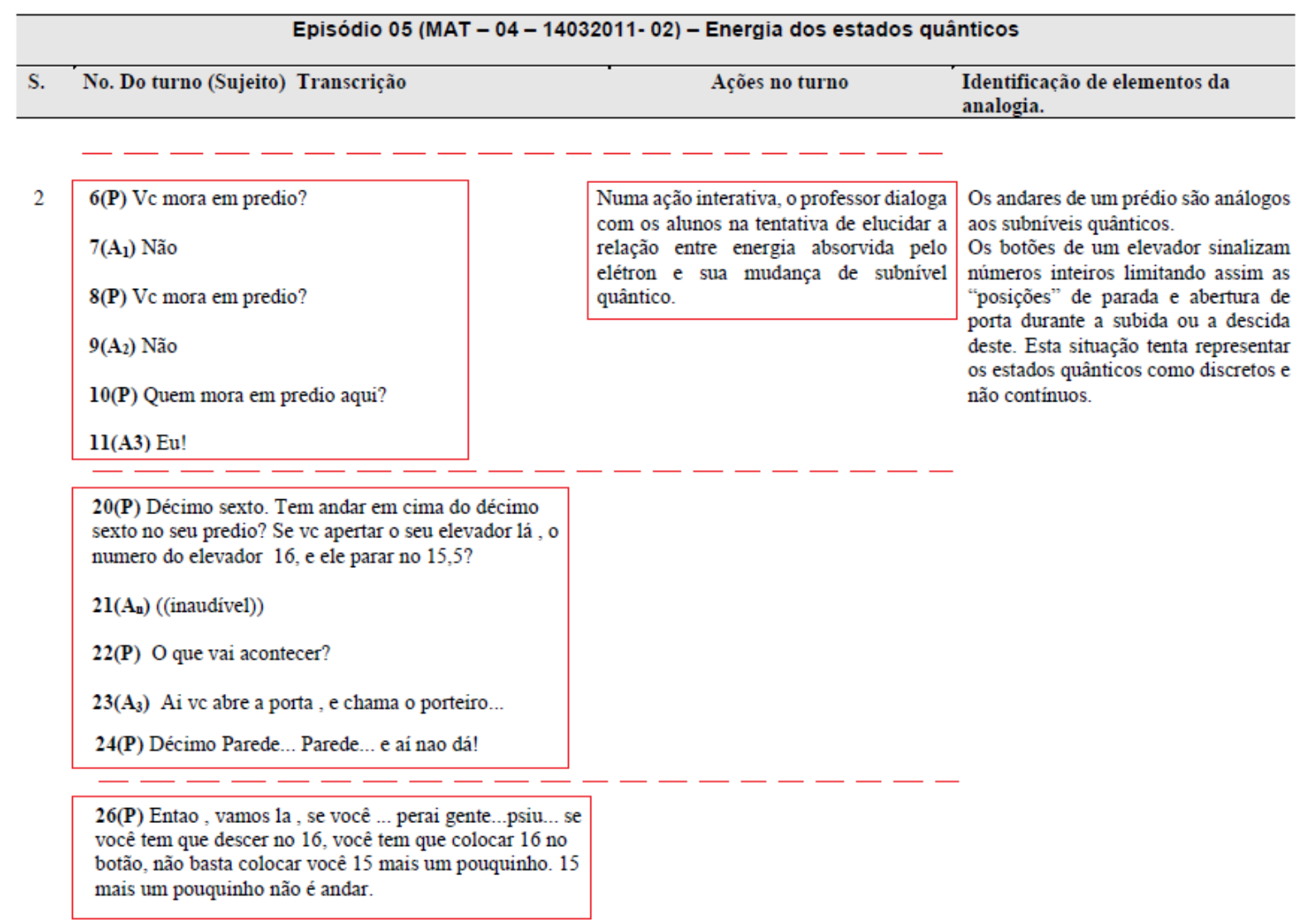

Figura 7.20 - Fragmento (2) do episódio 05 
No episódio 06 [(EFE/ NDL - 06 - 30112012- 01) -O efeito fotoelétrico modelos ondulatório e corpuscular da luz.], assim como no episódio 05, a ação analógica é curta. Trata-se de uma aula cujo tema é o efeito fotoelétrico, e na qual a ênfase é dada na comparação entre os modelos ondulatório e corpuscular da luz e as previsões de cada uma delas para o fenômeno. O professor interrompe seu encaminhamento e apresenta a analogia da chuva a fim de reforçar o caráter descontínuo da luz no modelo corpuscular.

\begin{tabular}{llcl}
\hline \multicolumn{3}{c}{ Episódio 06 (EFE/ NDL - 06 - 30112012- 01) -O efeito fotoelétrico - modelos ondulatório e corpuscular da luz. } \\
\hline S. No. Do turno (Sujeito) Transcrição & Ações no turno & $\begin{array}{l}\text { Identificação de elementos da } \\
\text { analogia. }\end{array}$ \\
\hline
\end{tabular}

12 (P) Toda vez que esses fótons, que são partículas aqui, ó, elas batem no metal, cada fóton desse ó, cada partícula dessa, dá toda energia dela para o elétron do metal, e aí você consegue arrancar os elétrons do metal.

13 (P) Aqui ... qual é a grande diferença daqui para essa representação? Aqui a luz é como se fosse uma coisa contínua, e ela pode ter qualquer valor de energia.

14 (P) Aqui nessa representação já muda completamente, concorda? Aqui por exemplo, a luz não é mais uma coisa contínua , é como se fosse uma coisa granulada.

15 (P) Pessoal, vamos pensar nas gotas de chuva, se você A fim de reforçar o contraste entre os As gotas da chuva representam o olhar a chuva caindo de longe, ela não tem esse aspecto conceitos de "coisas discretas" x "coisas carater discreto da luz.

aqui ó ((desenha no quadro)), parece um coisa contínua? continuas", o professor lança mão de uma A impressão de continuidade da Parece eu não tem divisão, a chuva quando tá caindo. analogia que é apresentada em sua chuva representa a "falsa" impressão Mas se a gente fosse capaz de olhar a luz...a chuva de um narrativa e reforçada por representações do carater contínuo da luz. jeito mais Próximo, você percebe que a chuva, ela não é pictóricas no quadro.

continua desse jeito, ela é formada de pequenas gotículas.

16 (P) Então aqui ó((aponta pro desenho no quadro)), é a representação que a gente tem hoje de como seria a luz, a luz não é uma coisa contínua, a luz é formada por partículas, essas partículas o Einstein né,acabou batizando de fótons, e toda vez que esses fótons batem aqui no metal, dependendo da energia que esses fótons tiverem, você consegue arrancar elétrons, essa é a idéia.

Figura 7.21 - Fragmento (2) do episódio 06

Apesar de notarmos, na Figura 7.21, ações do professor que recorrem a representações gráficas no quadro, estas não correspondem ao sujeito da analogia, antes se referem aos modelos ondulatório e corpuscular da luz. Sendo assim, a apresentação da ação analógica presente neste episódio pertence ao formato "Verbal".

Ainda na mesma lógica de ações analógicas de curta duração, o episódio 07 [(NDL - 07 - 30112012- 04) - Interpretação dualista realista para o experimento monofotônico] é referente a uma aula a respeito de algumas das principais 
interpretações da MQ. Os turnos destacados correspondem ao momento em que o professor lança mão da analogia do surfista, ao discutir com os alunos a interpretação dualista realista. Ele o faz por meio de sua narrativa, mas reforçada por representações pictóricas feitas no quadro. A Figura 7.22 representa o fragmento com os turnos relevantes à presente análise.

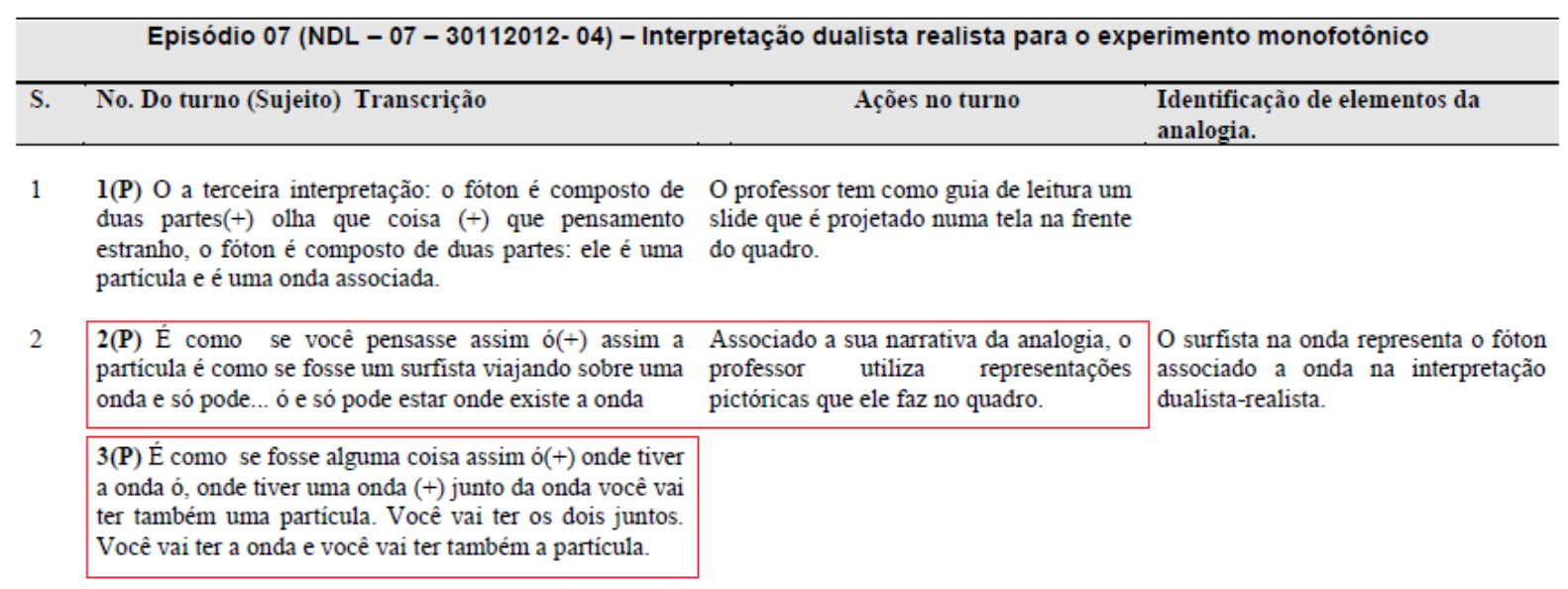

Figura 7.22 - Fragmento (2) do episódio 07

Com base nas ações do professor na referida atividade analógica, classificamos o presente formato de apresentação como "Verbal-representativo".

O último episódio analisado nesta seção corresponde a uma aula cujo tema é o efeito fotoelétrico. No episódio 08 [(EFE - 08 - 22112012- 04) - Efeito fotoelétrico], no contexto de uma aula do referido tema, a fim de destacar a falha do modelo ondulatório da luz na previsão do efeito fotoelétrico, o professor lança mão de uma analogia mecânica. Destacamos na Figura 7.23 que a ação analógica proposta por ele é restrita a uma apresentação narrativa. Tal fato confere ao presente episódio a classificação "Verbal" quanto ao formato de apresentação da analogia. 
1 ( 1 (P) Uma onda bate no material ela consegue ter uma $\mathrm{O}$ professor buscava evidenciar que interferência com esse material $(+)$ ela tem uma relação partir do modelo ondulatório da luz não com esse material tá? Uma interação com esse material. se conseguia explica o efeito fotoelétrico.

2(P) Por exemplo(+) no caso da ponte qua a gente viu a ponte ((gestos)) como é que você explica aquilo lá?

3(P) A onda vem ((gestos)) (+) o vento vem e aí a ponte começa a balançar. Quando a ponte tá balançando(+) quando ela tá voltando pro movimento dela lá $(+)$ pra parar (+) áá (++) o ar vem (+) né o vento $(+)$ a onda do ar bate e aumenta a amplitude e ai ela vem $(+)$ quando ela tá voltando bate de novo e aí ela vai aumentando a amplitude (+) né? A ponte (++) até uma hora que ela cai.

4(P) Isso a onda explica, o modelo ondulatório explica (+) é um negócio super básico né? (+) vai empurrando( $(+)$ vai empurrando e chega uma hora que começa $(++)$ ah ela balança também $(+)$ você vai empurrando vai empurrando vai aumentando a amplitude e tal (+) tem uma hora que não aguenta (+) não se sustenta mais e cai.

5(P) O problema é (+) esse tipo de explicação demora (+) esse tipo de efeito demora muito(+) então pra cair a ponte demora.

9(P) Ai a gente percebe que quando bate a luz ((gestos)) na hora sai o elétron $(+)$ esse é o problema.

10(P) Outro problema é você aumentar a intensidade luminosa $(+)$ então você aumenta ali aaa $(++)$ coloca uma luz mais forte entre aspas $(+)$ coloca uma luz mais clara $(+)$ deveria $(+++)$

11(P) E como se fosse um vento mais forte

12(P) (+) deveria ééé (++) o efeito ser mais imediato ainda

13(P) So que se você coloca a luz mais intensa(+) num (+) não acontece isso.

professor inicia uma narrativa de uma situação na qual uma ponte desaba sob ação do vento. Ele buscou a analogia da A ação do vento sobre a ponte é o análogo da ação da luz sobre uma placa metálica.

ponte a fim de contrastar com as previsões do experimento relativo ao feito fotoelétrico.

Retoma rapidamente a analogia da ponte e reforça a questão do fator intervalo de tempo no referido efeito.

Conclui que apresentando as previsões do efeito fotoelétrico a respeito da

14(P) Só vai mudar quando você muda a frequência $(+)$ quando você muda a cor da luz $(+)$ quando você muda 0 comprimento de onda. variação da amplitude e da variação da frequência da luz incidente no material. Vale destacar que os alunos participaram de uma aula na qual eles utilizaram um simulador do efeito fotoelétrico e 15(P) Então pra uns tipos de luz dá o efeito fotoelétrico "verificaram" as observações feitas aqui $(+)$ pra outros tipos não dá $(+)$ e aí era um problema pelo professor. também.

Figura 7.23 - Fragmento (2) do episódio 08

\subsection{As analogias como atividades didáticas planejadas}

Seria suficiente ter acesso ao planejamento dos professores para inferirmos com certeza se analogias faziam parte de suas ações planejadas. Restaria olhar para os eventos, a fim de discutir se ocorreram certas ações prévias à atividade 
analógica. Contudo, nosso objetivo não é apenas investigar se tais atividades constam ou não no planejamento de aula do grupo de professores, sobre cujas aulas construímos nossos dados. Sobretudo buscamos, influenciados pelo conceito de mudança do senso comum apresentado por Paty (2003), investigar, quando existentes, em que momentos ocorreram tais ações e em que nível.

Cada grupo de categorias visa, em nosso estudo de caso, abordar questões de pertinência referentes ao resultado de nossa síntese teórica. Na presente seção, propomos fazer um levantamento, nos oito episódios construídos, relativo à percepção de ações prévias das atividades analógicas. A pertinência da referida investigação se dá na medida em que percebemos a necessidade de pensar em analogias que sejam adaptadas ao compartilhamento de significados com alunos do ensino médio, ou seja, que deem conta de apresentar os conceitos relacionados à física quântica e que pertençam ao "repertório cognitivo" deles. Tal desafio parece representar a necessidade de aproximação em dois sentidos. Por um lado, investimos esforços a fim de tornar os conceitos mais "próximos" da compreensão dos alunos, por outro lado, é imprescindível "aproximá-los" dos conceitos. Ao segundo movimento atribuímos a importância das ações prévias na busca de mudanças de status do senso comum.

A fim de concluir nosso estudo de caso, propomos, então, uma breve análise de nossos episódios, sob a perspectiva aqui apresentada. Iniciamos pelo episódio 01 [(MAT - 01 - 01042011- 05) - Física Quântica, o que é?], no qual o professor lança mão de uma analogia "Figurativa" sob o formato "Verbal-representativo". Nossa inferência se deu basicamente na mudança de turno que vai resultar na apresentação da analogia. 


\begin{tabular}{|c|c|c|c|}
\hline \multicolumn{4}{|c|}{ Episódio 01 (MAT - 01 - 01042011- 05) - Física Quântica, o que é? } \\
\hline S. & No. Do turno (Sujeito) Transcrição & Ações no turno & $\begin{array}{l}\text { Identificação de elementos da } \\
\text { analogia. }\end{array}$ \\
\hline 1 & $\begin{array}{l}\text { I(P) (...) e graças a Max Planck, a atual fisica clássica } \\
\text { basicamente desmoronou (++)por quê? porque ele veio } \\
\text { com uma nova ideia uma nova }(++) \text { situação de:: uma } \\
\text { proposta nova de trabalbo }(+) \text { que é algo assim muito } \\
\text { absurdo }(+) \text { mas que funcionava }(++) \text { inclusive Max } \\
\text { Planck foi basicamente o pai da fisica quântica }(+) \text { e o } \\
\text { que que é a fisica quântica?/ }\end{array}$ & $\begin{array}{l}\text { O professor se posiciona no meio do } \\
\text { quadro e por meio de uma namativa com } \\
\text { viés histórico aponta para uma certa } \\
\text { incoerência da proposta de Planck para o } \\
\text { átomo. }\end{array}$ & \multirow{3}{*}{$\begin{array}{l}\text { Cada degrau da proposta escada } \\
\text { representa (é análogo) aos níveis de } \\
\text { energia dos elétrons em um átomo } \\
\text { qualquer. Parece que os pés } \\
\text { representados no desenho dos degraus } \\
\text { da escada representam os elétrons, } \\
\text { mas tal detalhe não é esclarecido pelo } \\
\text { professor. }\end{array}$} \\
\hline \multirow[t]{2}{*}{2} & $\begin{array}{l}\text { 2(P) /.../ 'muito bem' (++) quando você vai subir uma } \\
\text { escada }(+) \text { tem condiçòes de pisar no meio do degrau? }\end{array}$ & \multirow{2}{*}{$\begin{array}{l}\text { Na tentativa de explicar o conceito de } \\
\text { quantização de Planck, o professor lança } \\
\text { mão de uma analogia (subindo uma } \\
\text { escada degrau por degrau). Ao perceber } \\
\text { que de inicio os alunos nó } \\
\text { compreenderam, o professor recorre a } \\
\text { outros recursos representativos, a saber, } \\
\text { gestual e pictónco. Ele gesticula } \\
\text { simulando os degraus de uma escada e } \\
\text { em seguida desenha uma escada no } \\
\text { quadro. }\end{array}$} & \\
\hline & $\begin{array}{l}\text { 3(A } A_{E} \text { [[sim dá]] } \\
\text { 4(P) Será? Você tem um degrau aqui e outro degrau aqui. } \\
\text { Você consegue pisar no meio do degrau? } \\
5\left(A_{\varepsilon}\right) \text { [[ah não]] } \\
\text { 6(P)Pq não consegue?/pq a base... tem uma base embaixo }\end{array}$ & & \\
\hline
\end{tabular}

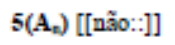

Figura 7.24 - Fragmento (3) do episódio 01

A mudança de turno destacada na Figura 7.24 não sugere qualquer ação prévia do professor. Ao contrário, os turnos destacados mostram uma mudança de tema repentina e a sugestão de um análogo (os degraus de uma escada e a ação de subir por meio desta) que pertence ao nível ordinário do senso comum. Com isso, o presente episódio corresponde à categoria "Ausência", quanto ao quesito indicações de ações prévias.

No episódio 02 [(MAT - 02 - 11032011- 05) - Instabilidade do átomo de Rutherford], há características particulares vinculadas à atividade analógica que evidenciam o seu planejamento. Tendo previsto a referida atividade, o professor leva para sala de aula um conjunto de objetos que por ele seriam usados. No entanto, conforme destacamos anteriormente, a ação prévia de planejar a atividade analógica é um dos elementos que buscamos. O segundo elemento diz respeito a ações que buscam mudanças no status do senso comum a partir do qual se propõe o análogo. Neste caso, nossa investigação torna-se mais apurada. 


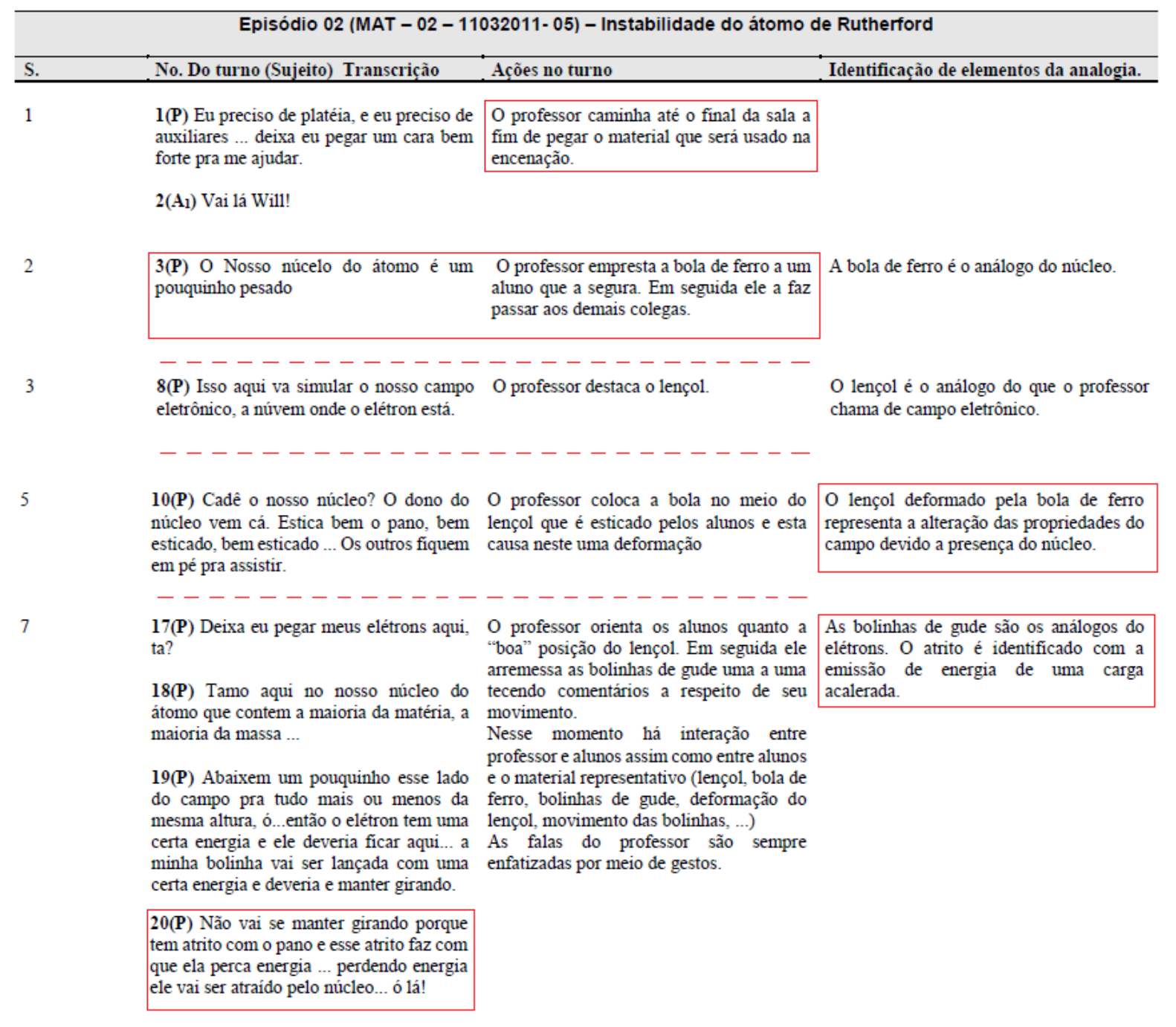

Figura 7.25 - Fragmento (3) do episódio 02

A figura 7.25 destaca alguns turnos da ação do professor os quais reforçam a percepção de que a presente atividade analógica foi precedida de planejamento. Ademais, destacamos que a dinâmica analógica proposta pelo professor conta com elementos que, em princípio, estariam fora do senso comum ordinário. Vale destacar que a palavra atrito pode estar associada a diversos conceitos, dependendo de seu contexto de uso. Entretanto, na referida atividade, esta é vinculada à mecânica e associada a outros conceitos físicos (como força, energia, velocidade, etc.). Por isso, as ações prévias aqui identificadas são classificadas como "Anteriores à ação de uso".

Como destacamos nas seções anteriores, o episódio 04 apresenta um conjunto de três analogias dentre as quais uma foi considerada como metáfora. A 
primeira analogia proposta pelo professor busca semelhanças entre um jogo de tabuleiros e o caráter discreto da energia presente no efeito fotoelétrico. Esta apresenta indícios de planejamento, uma vez que o professor menciona questões da analogia discutida na aula anterior. A propósito, a inserção dos dados defeituosos a fim de problematizar e provocar nos alunos "incertezas" reforça a ideia de esta atividade ser precedida de planejamento. Já as duas analogias "auxiliares" propostas pelo professor destacam-se pelo seu caráter de improviso, o qual pode ser constatado nas mudanças súbitas de turno, conforme apresentamos na Figura 7.26.

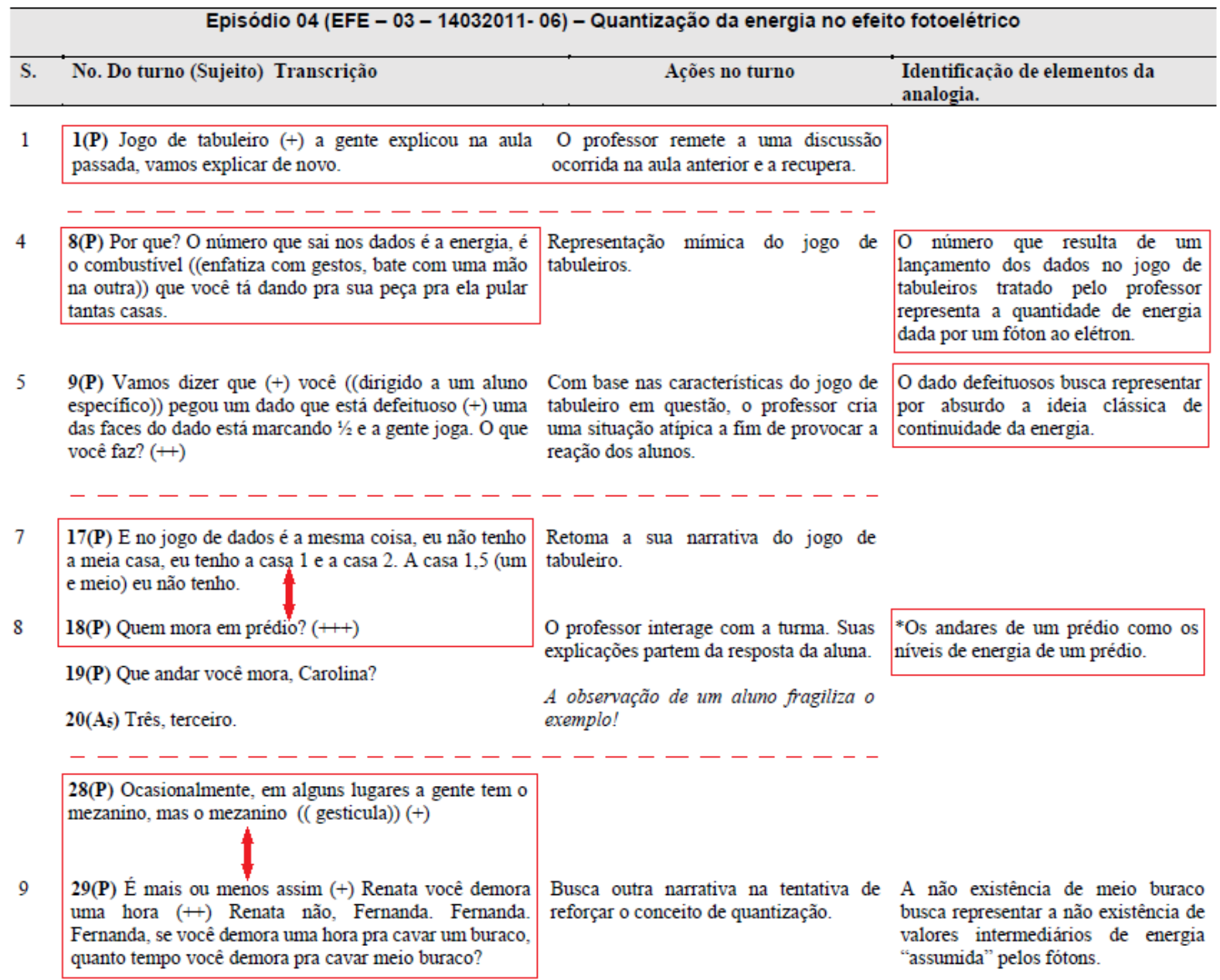

Figura 7.26 - Fragmento (3) do episódio 04

As duas atividades analógicas intermediárias (dos andares de um prédio e da ação de cavar buracos) se apresentam como ausentes de ações prévias, no entanto, tomando como principal a primeira ação analógica (do jogo de tabuleiros), a 
classificação do episódio 04 na perspectiva de indicações de ações prévias como "Anterior à ação de uso".

O episódio 05 [(MAT - 04 - 14032011- 02) - Energia dos estados quânticos] apresenta uma analogia presente também no episódio anterior. A fim de abordar a descontinuidade da energia nos estados quânticos, o professor lança mão da analogia figurativa dos andares de um prédio. Tal analogia parece pertencer a seu repertório, mas isso não confere a ela um grau de atividade planejada, segundo a perspectiva adotada. Afinal, como discutimos anteriormente, o objetivo de nossa investigação no presente grupo de categorias não se limita a inferir se houve ou não planejamento das atividades analógicas. Antes, porém, caso haja indícios de que a atividade foi planejada, buscamos discutir a possibilidade da existência de ações volitivas que buscam o que chamamos de mudança do status do senso comum. $\mathrm{Na}$ verdade, na presente tese, buscamos olhar ações didáticas de uso de analogias em aulas sobre temas relacionados aos conceitos quânticos. Então, pela especificidade do domínio do conhecimento aqui tratado, julgamos que as analogias "adaptadas" a estas atividades devem partir de análogos que estejam além dos objetos/conceitos do senso comum ordinário, ou seja, que não sejam pautados apenas nas "relações diretas" com o mundo sensível.

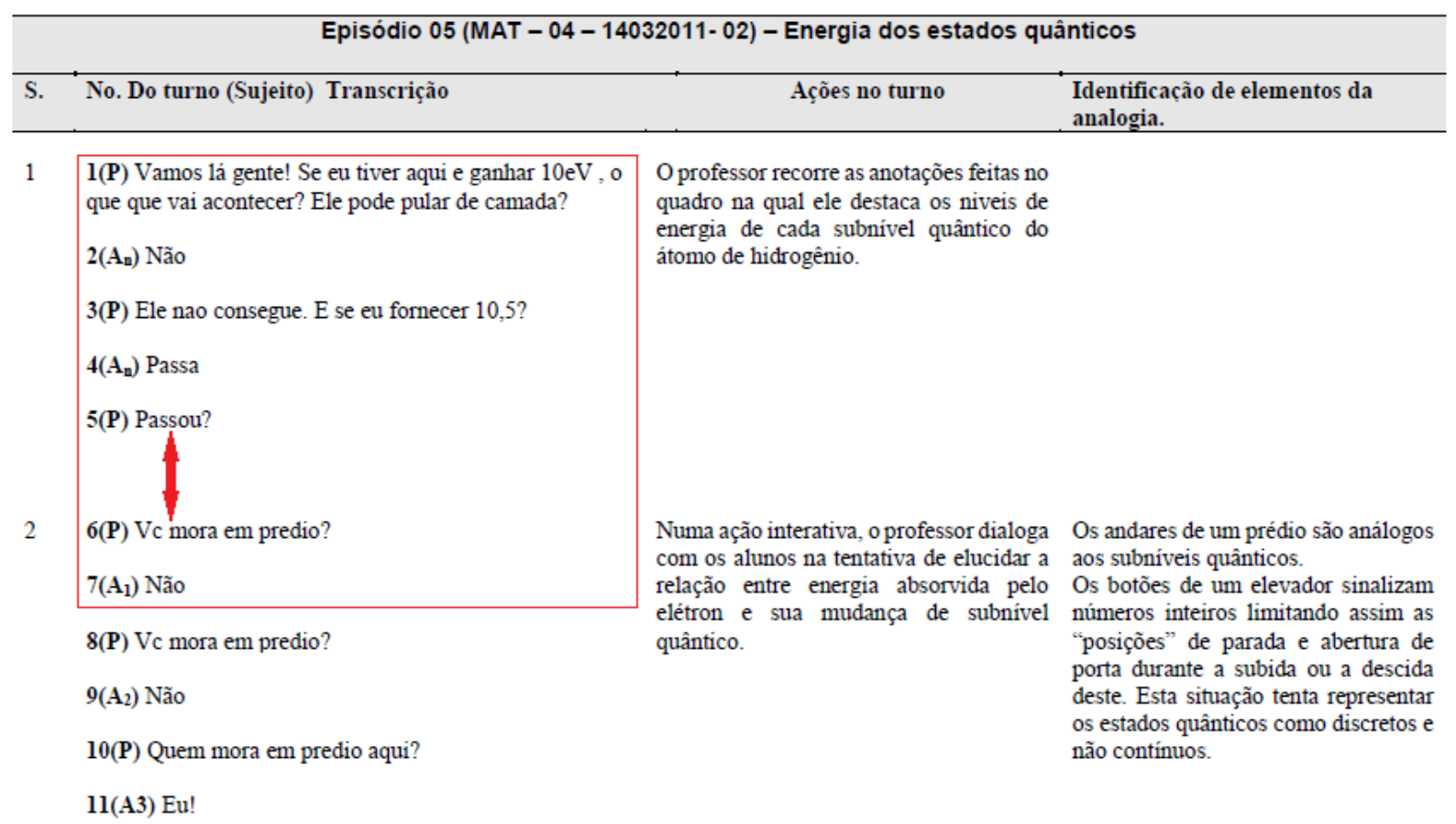

Figura 7.27 - Fragmento (3) do episódio 05 
O fragmento apresentado na Figura 7.27, associado às discussões precedentes, nos permite atribuuir ao presente episódio a categoria "Ausência" de ações prévias.

Como na maioria dos casos analisados, o episódio 06 [(EFE/ NDL - 06 30112012- 01) -O efeito fotoelétrico - modelos ondulatório e corpuscular da luz] apresenta uma ação analógica figurativa. Esta buscava, dentro do contexto de uma aula cujo tema principal era o efeito fotoelétrico, reforçar o aspecto discreto presente no modelo corpuscular da luz. O professor então lança mão da analogia que busca semelhança entre os quanta de luz e as gotas da chuva.

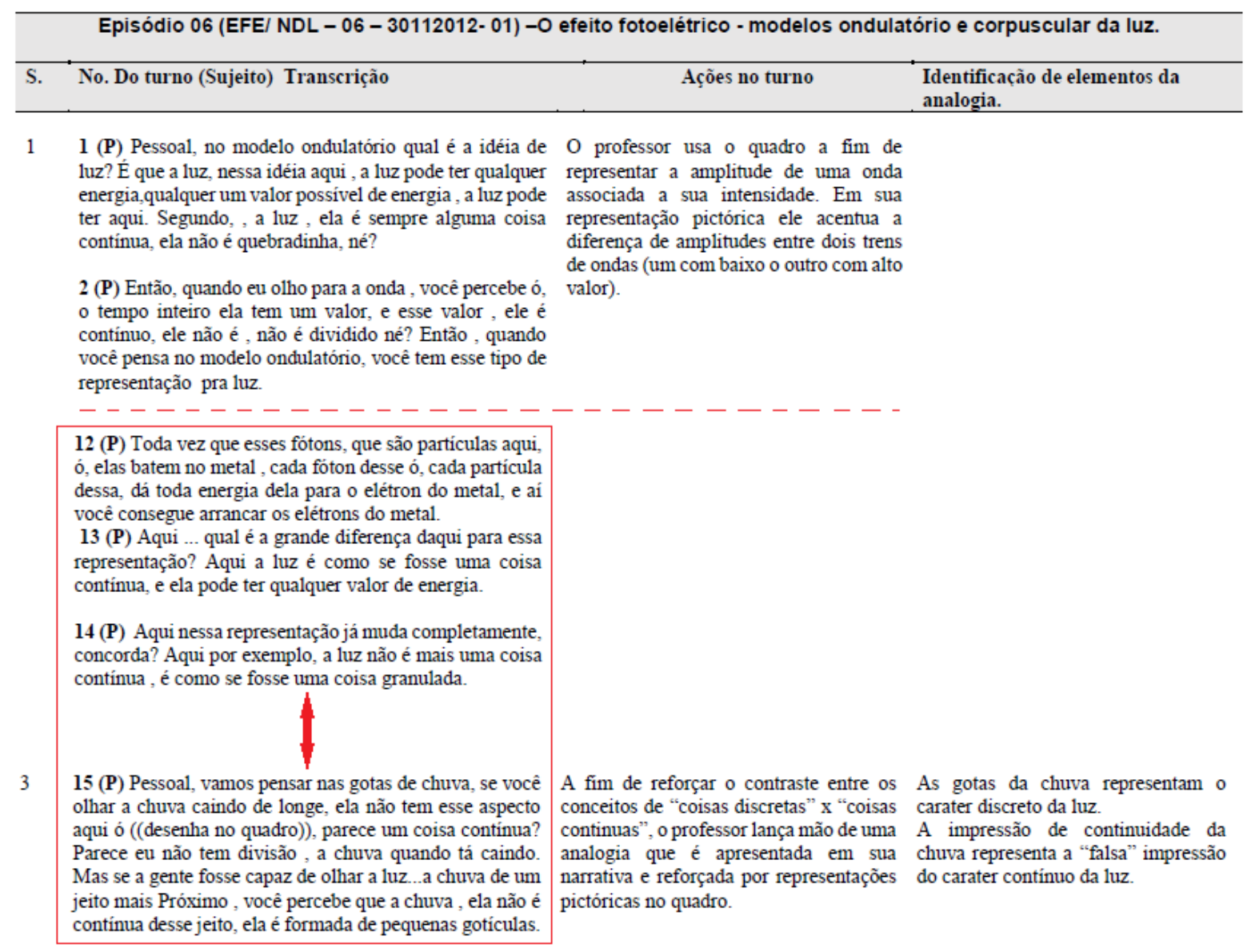

Figura 7.28 - Fragmento (3) do episódio 06

A ação analógica referente ao episódio 06 não é apresentada de forma súbita. Os turnos anteriores, destacados na Figura 7.28, tratam de uma narrativa muito próxima àquela que introduz a analogia. Sendo assim, mesmo que esta não tenha 
sido planejada de forma detalhada, a referida ação analógica é precedida de ações prévias. Por isso, a classificamos na categoria "Sincrônica à ação de uso".

No episódio 07 [(NDL - 07 - 30112012- 04) - Interpretação dualista realista para o experimento monofotônico], o professor lança mão da analogia do surfista, a fim de apresentar a interpretação dualista realista. No entanto, como destacamos anteriormente, esta se encontra em Pessoa Jr (2003b), o que sugere que o docente decidiu previamente incorporá-la à sua aula. Na verdade, na aula a partir da qual construímos o presente episódio, a referida analogia foi apresentada em um dos slides projetados pelo professor, o que reafirma certo grau de planejamento da presente atividade analógica.

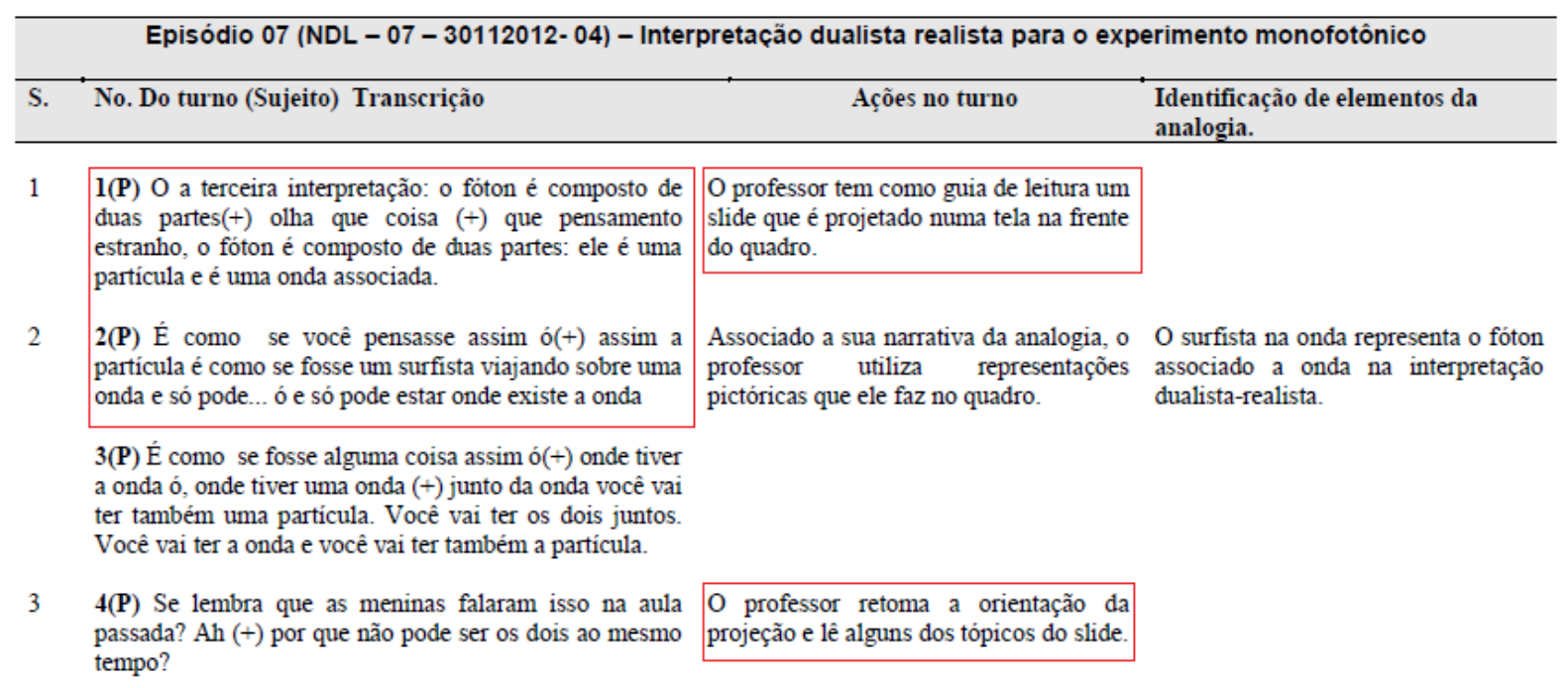

Figura 7.29 - Fragmento (3) do episódio 07

No entanto, tendo em conta que o planejamento da referida atividade analógica é restrito à decisão de uso em sala de aula, classificamos a presente analogia na categoria "Ausência" de ações prévias. Ainda que tal categorização seja aparentemente contraditória, a não rigidez proposta a esse grupo de categorias visa a uma análise mais reflexiva. Na verdade, a presente analogia aparece como figurativa e ilustrativa. De fato, como ressaltado na Figura 7.29, esta se apresenta quase como um exemplo do que o professor acabara de apresentar. Vale destacar que a pertinência ou eficiência da analogia em questão não representam elementos de nossa análise. Tal classificação se deu fundamentalmente em função dos critérios aqui adotados. 
No episódio 08 [(EFE - 08 - 22112012- 04) - Efeito fotoelétrico], a fim de evidenciar as contradições entre os resultados experimentais e as previsões do modelo ondulatório da luz, o professor lança mão de uma analogia mecânica a partir da qual ele pauta suas considerações. Para análise do presente episódio, contamos com o auxílio de uma aula anterior (que não consta em nosso conjunto de aulas transcritas), na qual o professor apresenta um vídeo que mostra a ação do vento sobre pontes. Na ocasião, conceitos como força, energia (cinética e potencial), amplitude e ressonância foram discutidos com os alunos.

A Figura 7.30 também apresenta elementos que nos permitem conferir à presente ação analógica a classificação de "Anterior à ação de uso" no quesito indicações de ações prévias. Afinal, a atividade anterior, que apresentou aos alunos a ação do vento sobre uma ponte, não possuía outro objetivo que o de prepará-los para ação analógica que viria.

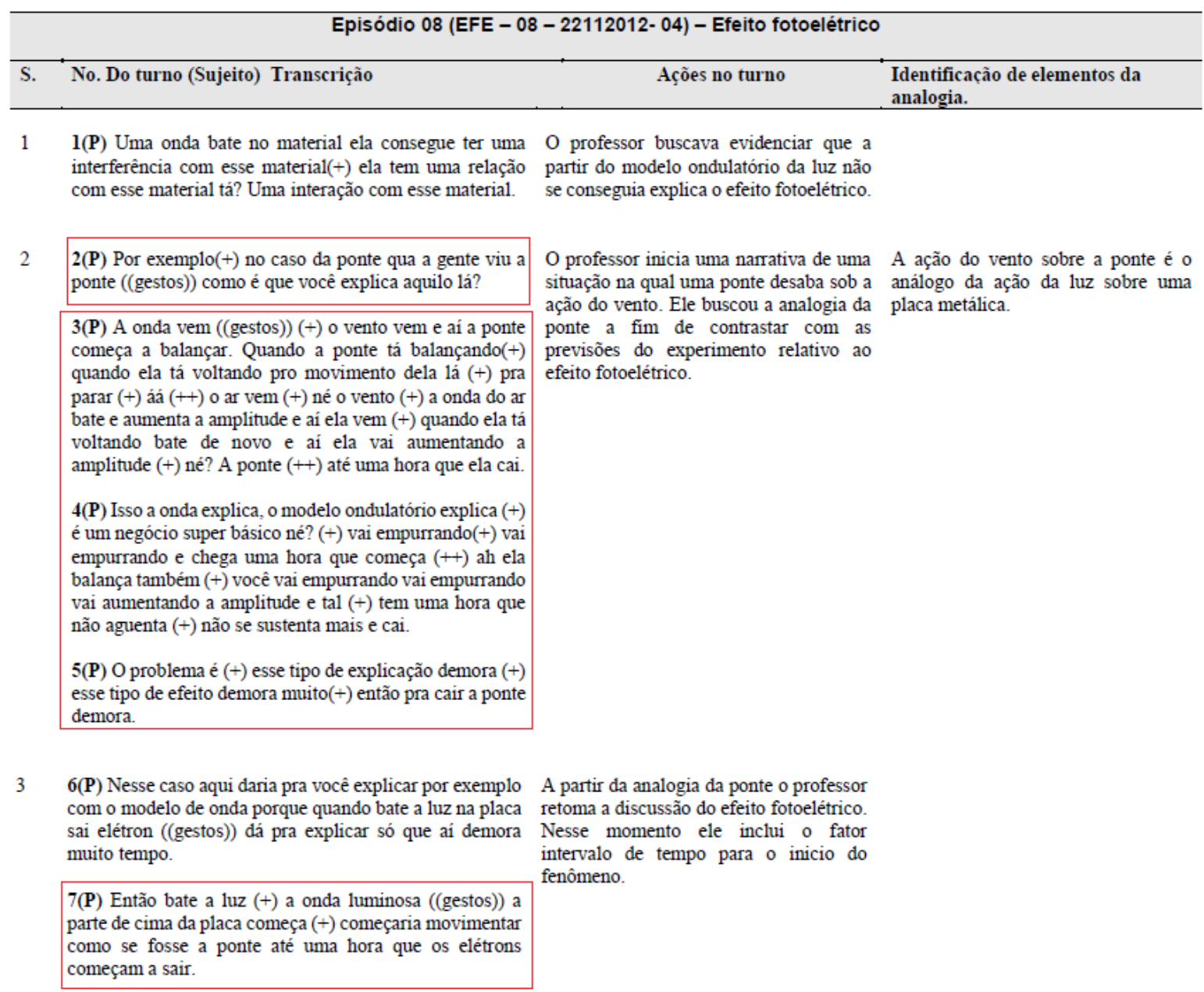

Figura 7.30 - Fragmento (3) do episódio 08 
Até aqui apresentamos uma "tripla análise" dos episódios realizadas nos grupos de categorias sugeridos na presente tese. Cientes das possíveis e ocasionais retomadas de discussões de um mesmo episódio, insistimos neste formato para a realização da classificação das atividades analógicas. Tal insistência se deu na medida em que entendemos que, desta forma, o "reaparecimento" de um mesmo conjunto de categorias contribuía não só com a apropriação dos sentidos envolvidos, como também nos "forçou" a retomar análises de episódios já realizadas, o que tornou mais rico nosso estudo de caso.

$\mathrm{Na}$ tentativa de reunir os resultados das classificações dos episódios, propomos a seguir algumas considerações a fim de obter um panorama geral do que foi descrito no presente capítulo.

\subsection{Algumas considerações}

Com a intenção de melhor visualizar o resultado da categorização dos episódios analisados, elaboramos o quadro abaixo:

Quadro 7.4 - Classificação em categorias dos episódios

\begin{tabular}{|c|c|c|c|}
\cline { 2 - 4 } \multicolumn{1}{c|}{} & \multicolumn{3}{c|}{ GRUPOS DE CATEGORIAS } \\
\cline { 2 - 4 } EPISÓDIOS & Nível da & Formato de & Indicações de \\
& analogia & apresentação & Ações prévias \\
\hline $\mathbf{0 1}$ & Figurativa (I) & Verbal-represent (II) & Ausência (I) \\
\hline $\mathbf{0 2}$ & Mecânica (II) & Verbal-represent (II) & Anterior à ação (III) \\
\hline $\mathbf{0 3}$ & Mecânica (II) & *Verbal-represent (II) & Sincrônica à ação (II) \\
\hline $\mathbf{0 4}$ & Figurativa (I) & Verbal (I) & Anterior à ação (III) \\
\hline $\mathbf{0 5}$ & Figurativa (I) & Verbal (I) & Ausência (I) \\
\hline $\mathbf{0 6}$ & Figurativa (I) & Verbal (I) & Sincrônica à ação (II) \\
\hline $\mathbf{0 7}$ & Figurativa (I) & Verbal-represent (II) & Ausência (I) \\
\hline $\mathbf{0 8}$ & Mecânica (II) & Verbal (I) & Anterior à ação \\
\hline
\end{tabular}


O Quadro 6.3 nos apresenta um panorama geral a partir do qual faremos algumas observações. Os índices entre parênteses utilizados na apresentação das categorias têm certa função hierárquica. Ainda que, no estudo de caso apresentado neste capítulo, não tenhamos atribuído valores às categorias, olhamos para atividades analógicas influenciados por questões concernentes à nossa pergunta inicial de pesquisa. Uma delas visa resolver a contradição do uso de analogias em atividades voltadas à comunicação de conceitos da física quântica. Portanto, como resultado de nossa investigação, apontamos certa topologia para o grupo de analogias em que algumas se apresentam como mais adaptadas a atividades voltadas aos referidos conceitos. Nisso consiste a hierarquia de nossas categorias.

Cada grupo contém três categorias, e cada categoria é caracterizada por um nível hierárquico dentro da atividade analógica. Por exemplo, no grupo de categorias voltadas ao nível da analogia, a relação crescente relativa à adaptação supracitada se dá das analogias "Figurativas" (nível menos adaptado-I) às "Matemáticas" (nível mais adaptado - III). Quanto à forma de apresentação, a categoria "Verbal" não é classificada no nível hierárquico mais baixo, porque julgamos essa forma de comunicação menos rica que as demais, ao contrário, afinal as categorias "Verbalrepresentativo" e "Matemático-representativo" são mediadas por esta. Por isso, o nível hierárquico atribuído às categorias deste grupo deve-se à pluralidade de formas representativas associadas (verbal, textual, pictórica, gráfica e matemática), assim como às formas em si.

O terceiro e último grupo de categorias usadas no estudo de caso diz respeito à existência de ações prévias às atividades analógicas. Assim como nos demais grupos, sugerimos aqui certa graduação das categorias. Tendo em vista questões levantadas nos capítulos anteriores referentes à importância de se incorporar, nas ações de planejamento, atividades analógicas, o nível das categorias presentes no referido grupo está associado ao grau de planejamento destas. No entanto, como enfatizamos nas seções anteriores do presente capítulo, na tentativa de incorporar as reflexões teóricas presentes em Paty (2003), agregamos aqui a ideia de se criarem ações volitivas tendo em vista mudanças no status do senso comum dos alunos. Logo, estas tornaram-se também parâmetros para graduação das categorias 
neste grupo. Desta forma, os índices (I), (II) e (III) apresentados no Quadro 6.3 correspondem ao nível hierárquico descrito de cada categoria.

Por último, destacamos que os episódios analisados aqui não apresentaram nenhuma categoria do nível (III) em suas ações analógicas nos dois primeiros grupos, e que metade das categorias atribuídas correspondem ao nível (I). No entanto, separamos o próximo capítulo a fim de traçar um panorama geral da tese, no qual incluímos detalhes referentes ao presente capítulo. 
CAPÍTULO 8 


\section{CONSIDERAÇÕES FINAIS}

Uma vez que identificamos, na literatura especializada em ensino de ciências, particularmente em artigos ligado ao ensino de física, diversos trabalhos que argumentam a favor de se trazer a física do século XX para as aulas do ensino médio, diversas são as ações necessárias para que isto seja uma realidade de fato. $\mathrm{Na}$ verdade, como apresentamos na presente tese, os argumentos a favor da atualização curricular nos parecem suficientemente convincentes se entendemos que o ensino de ciências desempenha um papel importante na formação do sujeito em seu tempo histórico, sem o privar das construções e reflexões historicamente estabelecidas. Sob esta perspectiva, a ciência na escola e particularmente a física devem incluir em seus objetivos garantir aos alunos a apropriação da cultura científica historicamente desenvolvida. É bem verdade que os currículos de ciências apresentam limitações de "espaço e tempo" e, por isso, ainda que fosse justificável, não podemos reconstruir literalmente toda a história do desenvolvimento da ciência. Em função disso, somos obrigados a fazer escolhas, ou seja, decidimos o que deve constar nos currículos escolares, como deve ser abordado e em que momento.

Apesar de julgarmos importante e pertinente, nossa reflexão não se propõe a fazer uma análise curricular aprofundada e tampouco detalhada. Antes, em concordância com diversos trabalhos, julgamos pertinente a abordagem de temas de FMC no ensino médio. Particularmente, nossa pesquisa se dedicou a pensar no ensino de física quântica no referido nível educacional.

Tendo em conta que esse domínio da física apresenta particularidades, destacamos a questão relacionada à sua representação. A presente tese surge da necessidade de se pensar formas de comunicação dos conceitos quânticos que sejam ao mesmo tempo adequadas a aulas de física voltadas a alunos do ensino médio e capazes de colocar em evidência questões, ao nosso ver, essenciais associadas aos "segredos" do mundo quântico.

Pensar, então, em analogias como ferramenta didática capaz de comunicar tais conceitos nos pareceu inicialmente contraditório, uma vez que as analogias baseiam-se sempre em situações, conceitos, ou experiências pregressas, e os conceitos da física quântica parecem negar relações, ao menos diretas, com 
qualquer experiência sensível. Nosso interesse inicial de pesquisa foi então superar, se possível, a contradição supracitada.

A interdisciplinaridade é uma prerrogativa da presente tese. Logo, na tentativa de construção de um quadro teórico que desse conta de nosso problema de pesquisa, recorremos a três domínios do conhecimento que pudessem compor nosso objeto. De fato, ao pensarmos no uso de analogias em aulas de física quântica, entendemos que tal atividade pode ser compreendida em três dimensões, evidenciadas de acordo com três perspectivas: (1) buscamos compartilhar conceitos e estes precisam ser incorporados à estrutura cognitiva do sujeito garantindo-lhes significados; (2) tais conceitos pertencem ao domínio da ciência, e por isso estão sujeitos a questões relacionadas ao seu desenvolvimento; (3) o contexto define como se estrutura a comunicação, por se tratar de atividades voltadas ao ensino, estratégias didáticas são incorporadas a fim de alcançar os objetivos previamente definidos. Logo, os três domínios do conhecimento aos quais recorremos se constituíram: na psicologia cognitiva, na epistemologia da ciência e na didática de ciências.

$\mathrm{Na}$ concepção que defendemos no presente trabalho, as analogias constituem o par dialético analogia-categorização a partir do qual os conceitos são formados na estrutura cognitiva do indivíduo. Os conceitos aos quais nos referimos abrangem estes presentes nas atividades mais rudimentares, assim como aqueles presentes em atividades como a ciência e a matemática. A seguir, buscamos, na epistemologia da ciência, em particular na epistemologia segundo Poincaré, as possibilidades de uso de analogias nas atividades da ciência na formação dos novos conceitos científicos. A partir de algumas considerações baseadas na obra do epistemólogo da ciência francês, percebemos a presença da referida "ferramenta" do pensamento humano na elaboração das teorias da física. $\mathrm{Na}$ verdade, como desenvolvemos em nosso texto, nos apropriamos de três níveis/categorias de analogias a partir das quais olhamos as aulas em nosso ensaio empírico. A última dimensão que constituiu nossa tríade teórica se baseou em pesquisas das últimas décadas que se dedicaram a sistematizar o uso de analogias em atividades didáticas voltadas especificamente a aulas de ciências. 
Nossa síntese teórica nos permitiu criar uma estrutura metodológica capaz de colocar em evidência questões relevantes no que concerne ao uso de analogias em aulas de ciências. Fundamentalmente nos dedicamos a observar ações de professores em suas aulas sobre temas de física quântica, em episódios específicos nos quais eles lançaram mão do uso da referida ferramenta didática. Apesar de nosso ensaio empírico não se constituir a parte mais relevante da presente tese, este nos permitiu perceber que as analogias ainda são utilizadas em sala de aula como exemplos particulares que desempenham fundamentalmente a função de "dar uma ideia" do que está sendo apresentado. Conectivos do tipo: "é como se fosse..." ou "pense em..." reforçam a ideia de caso particular que se assemelha ao que se propõe ensinar ou comunicar. No entanto, como elemento fundamental do pensamento, as analogias não podem estar restritas a ações particulares e que, segundo nosso perspectiva, diminuem o potencial dessa ferramenta.

Conforme apresentamos no capítulo 1, baseados na literatura, é possível criar categorias que classifiquem os trabalhos voltados à implementação de temas de FMC na educação básica. As quatro revisões bibliográficas por nós destacadas nos permitem fazer uma breve síntese a respeito dessas categorias. Sem tecer discussões mais aprofundadas a respeito das categorizações apresentadas, destacamos o conjunto de categorias sugeridas por Silva e Almeida (2011) : (1) Revisão da literatura sobre o ensino de FQ/FMC; (2) Análise curricular; (3) Análise de conteúdos de FQ/FMC presentes em livros didáticos; (4) Elaboração e/ou aplicação de proposta de ensino; (5) Concepções dos professores a respeito do ensino de FQ/ FMC no ensino médio. Do presente conjunto ressaltamos a falta de reflexões que sejam comprometidas com as questões particulares por nós destacadas, a saber, o problema de representar/comunicar conceitos que têm em sua "ontologia/ epistemologia" a impossibilidade de representação com os elementos de nossa realidade sensível. Na verdade, mesmo no levantamento bibliográfico proposto por Pereira e Ostermann (2009), no qual há uma distinção de trabalhos classificados como de consulta para professores daqueles que apresentam algum resultado de experiência, tais questões são ausentes nos trabalhos citados.

Nesse sentido, a contribuição da presente tese vem ao encontro de trabalhos que apontam a necessidade de se incorporar, na formação inicial e continuada dos professores, discussões a respeito do uso de analogias em aulas de ciências 
(HARRISON, 2008; VENVILLE, 2008). No entanto, em particular nossa contribuição maior encontra espaço na medida em que não vimos na literatura trabalhos que abordassem a questão do uso de analogias em aulas de FQ. Mais uma vez baseados em nossa síntese teórica, primeiramente acreditamos ter demostrado a possibilidade do uso de analogias em atividades de ensino de $F Q$, tendo em vista a presença da referida ferramenta do pensamento na elaboração de teorias do século $\mathrm{XX}$, como o caso da teoria dos quanta de Einstein. Em segundo lugar, reforçamos a necessidade de se investir em pesquisas que reúnam estes dois elementos, a fim de que surjam contribuições futuras para a área de Ensino de Física.

Fundamentalmente por se tratar de atividades didáticas que buscam a construção de sentidos na comunicação dos conceitos ligados à Física Quântica, as analogias utilizadas devem "romper" com as comparações particulares imediatas. Nesse sentido, as analogias matemáticas desempenham um papel importante no compartilhamento de significados de tais conceitos. Nossa pesquisa inicia reflexões a respeito da concepção de mudança do senso comum apresentada por Paty (2003), no sentido de tornar inteligíveis os conceitos da FQ a alunos do ensino médio, principalmente por não possuírem em seu "repertório" o formalismo matemático a partir do qual a teoria quântica é expressada. Apontamos aqui, como possibilidade de continuação da presente pesquisa, o diálogo entre 0 desenvolvimento de "estágios do senso comum" que possibilite a compreensão dos conceitos quânticos por meio de analogias matemáticas. $\mathrm{Na}$ verdade, o que apontamos aqui é uma releitura e recontextualização dos conceitos de senso comum e de analogia matemática, uma vez que tais conceitos foram construídos e discutidos, tanto por Michel Paty, relacionado ao primeiro, quanto por Henri Poincaré, no caso da analogia matemática, no campo da epistemologia.

Destacamos que o desafio maior de uma tese que se propõe a incorporar em sua estrutura teórica a característica interdisciplinar, é correr o risco de, por um lado, se estender em temas específicos de dada área do conhecimento, fugindo assim de seu objetivo principal, ou, por outro lado, de abordar diversos domínios do conhecimento de forma superficial sem trazer verdadeiras e necessárias contribuições à questão de pesquisa. Dentro de certas limitações, a presente tese trouxe elementos consistentes da psicologia cognitiva, na perspectiva da presença constante do par dialético analogia-categorização na formação dos conceitos em 
geral. No campo da epistemologia, buscamos nas obras de Poincaré, apoiados na leitura dos artigos de Michel Paty, assim como contando com suas orientações, entender o papel das analogias na elaboração do conhecimento científico. Foi então, a partir dessa ampla leitura, que estabelecemos as três categorias relativas ao nível das analogias utilizadas, assim como as categorias associadas ao formato de apresentação.

Finalmente destacamos que, ao final desse percurso, as discussões teóricas e as reflexões provenientes de nosso ensaio empírico nos permitem apontar uma longa e promissora trajetória a respeito do tema uso de analogias em aulas de física quântica. É bem verdade que, sem abusar do processo indutivo, questões aqui levantadas podem ser recontextualizadas e incorporadas a atividades de ensino voltadas a outros temas de FMC. Por meio do trabalho e esforço despendido na presente tese, julgamos ser este um projeto consistente que propõe ações e discussões efetivas ao tema uso de analogias em aulas de FQ no ensino médio. 


\section{REFERÊNCIAS}

AINSWORTH, S. The functions of multiple representations. Computers \& Education, v.33, p.131-152, 1999.

.The educational value of multiple representations when learning complex scientific concepts. In J. K. Gilbert, M. Reiner, \& M. Nakhlel (Eds.), Visualization: Theory and practice in science education (pp. 191-208). New York: Springer, 2008.

ARAÚJO NETO, W. N. Formas de uso da noção de representação estrutural no ensino superior de química. 2009. 228f. Tese (Doutorado em Educação) Faculdade de Educação da Universidade de São Paulo, São Paulo. 2009.

ARLEGO, M. J. F. Los fundamentos de la mecánica cuántica en la escuela secundaria utilizando el concepto de integral de camino. Revista Electrónica de Investigación en Educación en Ciencias, ano 3, n. 1, 2008. Disponível em: $<$ http://reiec.sites.exa.unicen.edu.ar/anonro1/REIEC anio3 num1 art6.pdf?attredire cts $=0$ > Acesso em: 28 maio 2015.

ARRIASSECQ, I.; GRECA, I. M. Enseñanza de la teoría de la relatividad especial en el ciclo polimodal: dificultades manifestadas por los docentes y textos de uso habitual. Revista Electrónica de Enseñanza de las Ciencias, Vigo, v. 3, n. 2, 2004. Disponível em: <www.saum.uvigo.es/reec >. Acesso em: 27 mai. 2015.

AUBUSSON, P.J.; HARRISON A.G; RITCHIE S.M. Metaphor and Analogy in Science Education. Springer. 2006. 210p.

AUBRECHT, G. J. et al. Introductory students' ideas about quantization and photon. Announcer, College Park, v. 29, n. 2, p. 102, 1999.

BACHELARD, G. La formation de l'esprit scientifique : Contribution à une psychanalyse de la connaissance objective. Paris: Librairie philosophique $\mathrm{J}$. VRIN. 1934. 257p.

Brasileiro. 2000.151p.

O novo espírito científico. $3^{a}$ ed. Rio de Janeiro: Tempo 
. A formação do espírito científico. $9^{\text {a }}$ ed. Rio de Janeiro: Contraponto. 2011. 316p.

BAKHTIN. M. "Estética da Criação Verbal": São Paulo: Martins Fontes, 1997. . Marxismo e Filosofia da Linguagem.14a edição. São Paulo: Hucitec. 2010. 203p.

BASSO, I. S. As condições subjetivas e objetivas do trabalho docente: um estudo a partir do ensino de história. Tese de doutorado. Faculdade de Educação da Universidade Estadual de Campinas. 1994.

BITBOL, M. Mécanique quantique - une introduction philosophique. Paris: Flammarion. 1999. 483p.

BLANCHÉ R. - Le Raisonnement. - Paris : Presses Universitaires de France, 1973. - 264 p. - (Bibliothèque de philosophie contemporaine-PUF).

BOZELLI, F.C. e NARDI, R. Interpretações sobre o conceito de metáforas e analogias presentes em licenciandos de física. Enseñanza de las ciências. Barcelona: extra, 1-5, 2005.

BRASIL. Parâmetros Curriculares Nacionais para o Ensino Médio. Ministério da Educação/Secretaria da Educação Média e Tecnológica, Brasília, 1999.

PCN+ Ensino Médio: Orientações Educacionais Complementares aos Parâmetros Curriculares Nacionais para o Ensino Médio. Ciências da natureza, Matemática e suas tecnologias. Ministério da Educação/Secretaria da Educação Média e Tecnológica, Brasília, 2002. 
BROCKINGTON, G. A Realidade escondida: a dualidade onda-partícula para estudantes do Ensino Médio. 2005, 268f. Dissertação (Mestrado em Ensino de Física) Instituto de Física, Instituto de Química, Faculdade de Educação. Universidade de São Paulo, São Paulo, 2005.

BROWN, D. e CLEMENT, J. Overcoming misconceptions via analogical reasoning: Abstract transfer versus explanatory model construction. Instructional Science, 18, 237-261, 1989.

BUARQUE, Chico. Apesar de você. Disponível em: <http://letras.mus.br/chicobuarque/7582/>. Acesso em:19 abril 2013.

BUDDE, M.; NIEDDERER, H.; SCOTT, P.; LEACH, J. The quantum atomic model 'Electronium': a successful teaching tool. Physics Education, London, v. 37, n. 3, p.

204-210, 2002.

CAILLOT, M. La théorie de la transposition didactique est-elle transposable? In: RAISKY, C; CAILLOT, M. (eds.). Au-delà des didactiques, le didactique: débats autour de concepts fédérateurs. Paris-Bruxelas: De Boeck \& Larcier. 1996 ; p. 1935.

CAROLAN, J., PRAIN, V., \& WALDRIP, B. Using representations for teaching and learning in science. Teaching Science, 54 (1), 18-23, 2008.

CARVALHO, A.M.P. Uma metodologia de pesquisa para estudar os processos de ensino e aprendizagem em salas de aula. IN: SANTOS, F. M. T.; GRECA, I. M. A pesquisa em ensino de ciências no Brasil e suas metodologias. ljuí: Editora Unijuí. pp. 13-47. 2006.

CARVALHO NETO, R. A.; FREIRE JÚNIOR, O.; SILVA, J. L. P. B. Improving students' meaningful learning on the predictive nature of quantum mechanics. Investigações em Ensino de Ciências, v. 14, n. 1, 2009.

CASSIRER E. Substance et fonction. Éléments pour une théorie du concept. Paris : Les Éditions de Minuit, 1977. 429p.

Filosofia de las formas simbólicas III - Fenomenologia del Reconocimiento. 2aㅡ ed. México D.F.: Fondo de Cultura Econômica. 1998. 558p. 
. Filosofia de las Formas Simbólicas I : A linguagem. Trad. Marion Fleisher - São Paulo: Martins Fontes, 2001.

CAVALCANTE, M. A.; TAVOLARO, C. R. C. Uma oficina de física moderna que vise a sua inserção no ensino médio. Caderno Catarinense de Ensino de Física, v. 18, n. 3, p. 298-316, dezembro de 2001.

CHEVALLARD, Y. La transposición didáctica:del saber sabio al saber enseñado. Buenos Aires: Aique. 1991.

CROSSI FILHO, O. A epistemologia da ciência de Henri Poincaré : para além do convencionalismo e do realismo estrutural. 2012. 115f. Dissertação (Mestrado em Filosofia). Universidade São Judas Tadeu, São Paulo, 2012.

CRUZ-HASTENREITER, R. S. Analogies in High School Classes on Quantum Physics. Procedia - Social and Behavioral Sciences 167. pp.38-43. 2015.

CUPPARI, A.; RINAUDO, G.; ROBUTTI, O.; VIOLINO, P. Gradual introduction of some aspects of quantum mechanics in a high school curriculum. Physics Education, v. 32, n. 5, 1997.

CURTIS R. V. , e REIGELUTH C. M. The Use of Analogies in Written Text. Instructional Science, v.13, p.99-117, 1984.

DAGHER, Z. R. Analysis of analogies used by science teachers. Journal of Research in Science Teaching, 32(3), 259 - 270. 1995.

DESCARTES, R. Discours de la méthode. In: ADAM, Ch. \& TANNERY, P. (eds.). Oeuvres de Descartes. Vol. VI. Paris : Vrin.. p. 1-78. 1996.

DUARTE, N. Vigotski e o "aprender a aprender" : crítica às apropriacões neoliberais e pós -modernas da teoria vigostskiana. Campinas, SP, Autores Associados, 2001.

A teoria da atividade como uma abordagem para a pesquisa em educação. Perspectiva, Florianópolis, v. 21, № 2, p. 229-301. jul./dez 2003. 
DUARTE, M. C. Analogias na Educação em Ciências Contributos e Desafios. Investigacoes em Ensino de Ciencias , v.10(1), pp. 7-29, 2005.

DUIT, R. On the Role of Analogies and Metaphors in Learning Science. Science Education, 75 (6), 649-672. 1991.

DUPIN, J.J., \& JOHSUA, S. Analogies and "modelling analogies" in teaching. Some examples in basic electricity. Science Education, 73, 207-224. 1989.

DURAND-RICHARD, M. J.. L'analogie dans la démarche scientifique Perspective Historique. Paris: L'Harmattan. 2008.

EIDT N. M. e DUARTE, N. Contribuições da teoria da atividade para o debate sobre a natureza da atividade de ensino escolar, Psicologia da Educação, São Paulo, 24, p. 51-72, 2007.

ENGELS, F.; MARX, K. A ideologia Alemã. Boitempo Editorial. 2007.

FANARO, M. A.; ARLEGO, M.; OTERO, M. R. El Método de Caminos Múltiples de Feynman como Referencia para Introducir los Conceptos Fundamentales de la Mecánica Cuántica en la Escuela Secundaria. Caderno Brasileiro de Ensino de Física, v. 24, n. 2, 2007.

FANARO, M. A.; OTERO, M. R.; ARLEGO, M. Teaching the foundations of quantum mechanics in secondary school: a proposed conceptual structure. Investigações em Ensino de Ciências, v. 14, n. 1, 2009a.

FANARO, M. A.; OTERO, M. R.; MOREIRA, M. A. Teoremas-en-acto y conceptosen-acto en dos situaciones relativas a la noción de sistema cuántico. Revista Brasileira de Pesquisa em Educação em Ciências, v. 9, n. 3, $2009 \mathrm{~b}$.

FERNANDES, V.; Ernst Cassirer : o mito político como técnica de poder no nazismo. [ Tese (Mestrado em Filosofia) ). São Paulo : Pontifícia Universidade Católica de São Paulo, 2000. 
FISCHLER, H.; LICHTFELDT, M. Modern physics and students' conceptions. International Journal of Science Education, Londres, v. 14, n. 2, p. 181-190, 1992.

GIL, D.; SOLBES, J. The introduction of modern physics: overcoming a deformed vision of science. International Journal of Science Education, Londres, v. 15, n. 3, p. 255-260, 1993.

GIL PEREZ, D. Senet; F.; Solbes, J. La introduccion a la física moderna: un ejemplo paradigmatico de cambio conceptual. Enseñanza de las Ciencias, p. 189-195. 1987.

Contribución de la Historia y de la Filosofía de las Ciencias al desarrollo de un modelo de enseñanza/aprendizaje como investigación. Enseñanza de las Ciencias, v. 11, n. 2, p. 197-212, 1993.

GLYNN, S. M. Explaining science concepts: A teaching-with-analogies model. In S. Glynn, R. Yeany and B. Britton (Eds.), The psychology of learning science, Hillsdale, NJ, Erlbaum, p. 219-240, 1991.

GLYNN, S.M et al. Teaching science with analogies: a resource for teachers and textbook authors. Washington: National Reading Research Center. Disponível em: <http://curry.virginia.edu/go/clic/nrrc/scin ir7.html.> Acesso em: abril/2015. 1994.

GLYNN, S. M. Connect concepts with questions and analogies. In Koballa, T. R., \& Tippins, D.J. (Eds.). Cases in middle and secondary science education (2nd ed.), Upper Saddle River, NJ: Pearson Education. pp. 136-142. 2004.

$-55.2007$.

. The teaching-with-analogies model. Science and Children, 44(8), 52

GONÇALVES, M.E.R. Atividades de conhecimento Físico na formação de professores das Séries Iniciais. Tese (Doutorado) - Faculdade de Educação da Universidade de São Paulo. São Paulo.1997. 
GRANGIER, P.ROGER, G. and A. Aspect. Experimental Evidence for a Photon Anticorrelation Effect on a Beam Splitter: A New Light on Single-Photon Interferences. Europhys. Lett. 1(4). pp. 173-179. 1986.

GRECA, I. M. Construindo significados em mecânica quântica: resultados de uma proposta didática aplicada a estudantes de física geral. 2000,284f.. Tese (Doutorado em Física) - Universidade Federal do Rio Grande do Sul, Porto Alegre, 2000.

GRECA, I. M. ; MOREIRA, M. A. ; HERSCOVITZ, Victoria e . Uma proposta para o ensino de Mecânica Quântica.. Revista Brasileira de Ensino de Física (São Paulo), Porto Alegre, v. 1, n.23, p. 444-457, 2001.

GRECA, I. M.; MOREIRA, M. A. Uma revisão da literatura sobre estudos relativos ao ensino da mecânica quântica introdutória. Investigações em Ensino de Ciências, v. 6, n. 1, 2001.

HARRISON, A.G.; DE JONG, O. Using multiple analogies: Case study of a chemistry teacher's preparations, presentations and reflections. In: the proceedings of European Science Education Research Association. Dordrecht: Kluwer. 2004.

HARRISON, A. e TREAGUST, D. Teaching and Learning With Analogies: Friend or Foe?. In P. Aubusson, A.G. Harrison, \& S.M. Ritchie (Eds.). Metaphor and Analogy in Science Education, p. 11-31, 2006.

HARRISON, A.G. e COLL, R.K. Using Analogies in Middle and Secondary Science Classrooms. Corwin Press, Thousand Oaks, 2008. 275p.

HARRISON, A. G. Teaching With Analogies: Friends or Foes?. In: HARRISON, A. G.; COLL, R. K. (Eds.). Using Analogies in Middle and Secondary Science Classrooms. pp.6-21. 2008.

HAYES, D. A. e TIERNEY, R. J. Increasing Background Knowledge Through Analogy: Its Effects Upon Comprehension and Learning. Washington, D.C.: N1E, October, 1980.

HOFFMANN, B. Albert Einstein - créateur et rebelle. Paris : Seuil. 1975. 298p. 
hOFStADTER, D.; SANDER, E. L'Analogie Coeur de la Pensée. Paris : Odile Jacob Sciences, 2013. 688p.

JOENK, K. I. Uma Introdução ao Pensamento de Vygotsky: Revista do Programa de Pos-graduação em Educacao da Universidade Estadual de Santa Catarina. v.3, n.01, 2002.

JOHANSSON, K. E.; NILSSON, C.; ENGTEDT, J. SANDQVIST, A. Astronomy and particle physics research classes for secondary school students. American Journal of Physics, Melville, v. 69, n. 5, p. 576-581, 2001.

JONES, D. G. C. Teaching modern physics - misconceptions of the photon that can damage understanding. Physics Education, London, v. 26, p. 93-98, 1991.

JORGE, W. Analogia no Ensino da Física. Caderno Catarinense de Ensino de Física. Florianópolis, v. 7, n. 3: 196-202, dez, 1990.

KALKANIS, G.; HADZIDAKI, P.; STAVROU, D. An instructional model for a radical conceptual change towards quantum mechanics concept. Science Education, Hoboken, v. 87, n.2, p. 257-279, 2003.

KAUARK-LEITE, P. Théorie quantique et philosophie transcendantale: dialogues possibles. Paris : Hermann Éditeurs. 2012. 396p.

LANTOLF, J. P. Intrapersonal Communication and Internalization in the Second Language Classroom. In: KOZULIN, A. et al. (Ed.). Vygotsky's Educational Theory in Cultural Context. Cambridge: Cambridge University Press. 2003. pp. 339 -370.

LAPLACE, P.S. Essai philosophique sur les probabilités. New York: Cambridge University Press. 2009. 276p.

LAUTESSE et al. Enseigner la physique quantique en Terminale scientifique en France. L'objet quantique, une référence problématique. In : Huitièmes journées scientifiques de l'ARDIST - Marseille 12, 13 et 14 mars 2014. 
LAWRENCE, I. Quantum physics in school. Physics Education, London, v. 31, n. 5, p. 278-276, 1996.

LEONTIEV, A. N. Le déveleppement du psychisme. Paris: Éditions sociales, 1976. $343 p$.

Sobre o desenvolvimento histórico da consciência. In: LEONTIEV, A. O desenvolvimento do psiquismo. Lisboa: Horizonte Universitário. p. 89-142. 1978.

LOBATO T., GRECA, I.M. Análise da Inserção de Conteúdos de Teoria Quântica nos Currículos de Física do Ensino Médio. Ciência \& Educação, v.11, n.1, p.119132, 2005.

LÜDKE,M.;ANDRÉ,M. Pesquisa em educação: abordagens qualitativas. São Paulo: Editora Pedagógica e Universitária - EPU. 1986.

MARANDINO, M. Transposição ou recontextualização? Sobre a produção de saberes na educação em museus de ciências. Rev. Bras. Educ. [online]. 2004, n.26, pp. 95-108. Disponivel em : <http://dx.doi.org/10.1590/S1413-24782004000200008.> Acesso em : 02 março 2015.

MARKUS, G. Marxismo y Antropologia. Barcelona, Grijalbo, 1974.

MARTINS, R. de A. Introdução: a história das ciências e seus usos na educação. In: SILVA, C.C. (Org.) Estudos de história e filosofia das ciências: subsídios para aplicação no ensino. São Paulo: Editora Livraria da Física, p. xvii- xxx. 2006.

MARTINS, I. Dados como diálogo: construindo dados a partir de registros de observação de interações discursivas em salas de aula de ciências. IN: SANTOS, F. M. T.; GRECA, I. M. A pesquisa em ensino de ciências no Brasil e suas metodologias. Ijuí: Editora Unijuí. pp.297-321. 2006.

MARX, K. Manuscritos econômicos-filosóficos. In: FERNANDES, F. (org.). Marx e Engels: história. São Paulo: Ática, p. 147-181 (Coleção Grandes Cientistas Sociais). 1989. 
MARX, K.; ENGELS, F. Karl Marx on society and social change. Chicago; London: University of Chicago Press. 1973. 203 p.

MATTHEWS M. R. James T. Robinson's account of philosophy of science and science teaching: Some lessons for today from the 1960s. Science Education, Volume 81, Issue 3, Pages: 295-315, 1997.

MONTEIRO, M. A.; NARDI, R.; BASTOS FILHO, J. B. A Sistemática Incompreensão da Teoria Quântica e as Dificuldades dos Professores na Introdução da Física Moderna e Contemporânea no Ensino Médio. Ciência \& Educação, v. 15, n. 3, 2009.

MONTENEGRO, R. L.; PESSOA JR., O. Interpretações da Teoria Quântica e as Concepções dos Alunos do Curso de Física. Investigações em Ensino de Ciências, Porto Alegre, v. 7, n. 2, p. 107-126, ago. 2002.

MOOL, L. e GREENBERG, J. Creating zones of possibilities: combining social contexts for instruction. In: L. MOOL (org), Vygotsky and Education. Cambridge: Cambridge University Press. pp 319-48. 1990.

NEWMAN, F.; HOLZMAN, L. Lev Vygotsky: cientista revolucionário. São Paulo: Loyola, 2002. 241p.

NIEBERT, K. et al. Understanding Needs Embodiment: A Theory-Guided Reanalysis of the Role of Metaphors and Analogies in Understanding Science. Science education. Vol. 96, No. 5, pp. 849-877. 2012.

OLIVEIRA, M. K. Pensar a educação: contribuições de Vygotsky. In: PiagetVygotsky: novas contribuições para o debate. São Paulo: Ática, p. 51-81, 1988.

OLIVEIRA, F. F.; VIANNA, D. M.; GERBASSI, R. S. Física moderna no ensino médio: o que dizem os professores. Revista Brasileira de Ensino de Física, v. 29, n. 3, p. 447-454, Seção Pesquisa em Ensino de Física, 2007. 
OLSEN, R. V. Introducing quantum mechanics in the upper secondary school: a study in Norway. International Journal of Science Education, v. 24, n. 6, 2002.

OSBORNE, Roger; FREYBERG, Peter. Learning in Science. The Implications of Children's Science. Heinemann Educational Books, Inc., 70 Court Street, Portsmouth, NH 03801. 1985.

OSTERMANN, F.; MOREIRA, M. A. Física contemporánea em la escuela secundaria: uma experiencia en el aula involucrando formación de profesores. Enseñanza de las ciencias, Barcelona: v.18, n.3, p.391-404, 2000a.

- Uma revisão bibliográfica sobre a área de pesquisa "Física moderna e contemporânea no ensino médio". Investigações em Ensino de Ciências, v. 5, n. 1, 2000b.

OSTERMANN, F; RICCI, T. S. F. Construindo uma unidade didática conceitual sobre Mecânica Quântica: um estudo na formação de professores de Física. Ciência \& Educação, Bauru, v. 11, n. 2, p. 235-258, 2004 a.

OSTERMANN, F; RICCI, T. S. F. Relatividade restrita no ensino médio: os conceitos de massa relativística e de equivalência massa-energia em livros didáticos de Física. Caderno Brasileiro de Ensino de Física, Florianópolis, v. 21, n. 1, p. 83- 102, 2004 b.

OStermanN, F.; CAVALCANTI, C. J. H.; PRADO, S. D.; RICCI, T. S. F. Fundamentos da física quântica à luz de um interferômetro de Mach-Zehnder. Revista Electrónica de Enseñanza de las Ciências, v. 8, n. 3, 2009.

OTERO, M.R. ¿Cómo usar Analogías en Clases de Física? Caderno Catarinense de Ensino de Física. Florianópolis, v. 14, n. 2: p. 179-187, ago. 1997.

OTERO, M. R.; FANARO, M. A.; ARLEGO, M. Investigación y desarrollo de propuestas didácticas para la enseñanza de la Física en la Escuela Secundaria: Nociones Cuánticas. Revista Electrónica de Investigación en Educación en Ciencias, ano 4, n. 1, 2009. 
PATY, M. Einstein philosophe. La physique comme pratique philosophique, Presses Universitaires de France, Paris, 1993.

A ciência e as idas e voltas do senso comum. Scientia \& Studia, v. 1, n. 1. pp 9-26. 2003.

Pensée rationnelle et création scientifique chez Poincaré, Colloque Henri Poincaré "Science et pensées ", lundi 17 janvier 2005, CD-Rom Fondation Sophia-Antipolis, 2005, 19 p.

- Les Analogies Mathématique au Sens de Poincaré et leur Fonction en Physique. In: DURAND-RICHARD (org). L'analogie dans la démarche scientifique - Perspective Historique. Paris : L'Harmattan. Pp. 171-194. 2008

Analogie et intuition dans l'invention mathématique selon Poincaré, in Bour, Pierre Edouard; Rollet, Laurent; Rebuschi, Manuel (eds.), Construction. Festschrift for Gerhard Heinzmann. Festschrift en I'honneur de Gerhard Heinzmann, Collection «Tributes », King's College Publications, London, p. 51-62. 2010.

PAULO, I. J. C.; MOREIRA, M. A. Abordando conceitos fundamentais da mecânica quântica no nível médio. Revista Brasileira de Pesquisa em Educação em Ciências, v. 4, n. 2, 2004.

PEDUZZI, L. O. Q.; BASSO, A. C. Para o ensino do átomo de Bohr no nível médio. Revista Brasileira de Ensino de Física, São Paulo, v. 27, n. 4, p. 545-557, dez. 2005.

PEREIRA, A. P. OSTERMANN, F. Sobre o Ensino de Física Moderna e Contemporânea: Uma Revisão da Produção Acadêmica Recente. Investigações em Ensino de Ciências, vol. 14, pp. 393-420, 2009.

PESSOA JR., O. Kant Quântico . Filosofia e Consciência Social , Quarteto, Salvador, pp. 309-23, 2003a. 
Conceitos da Física Quântica. Volume I. Ed. Livraria da Física, São Paulo, 2003b. 189p.

Conceitos da Física Quântica. Volume II. Ed. Livraria da Física, São Paulo, 2006. pp 190-332.

PIAGET, J. ; INHELDER, B. A Psicologia da criança. Rio de Janeiro: Bertrand Brasil, 2003. 146p.

PINTO, A.C., ZANETIC, J. É Possível Levar a Física Quântica para o Ensino Médio?

Caderno Catarinense de Ensino de Física, Florianópolis, v. 16, n. 1, p. 7-34, abr. 1999.

PLANTIN, C. Analogie et m'etaphore argumentatives. In: L'Argumentation au Carrefour des Disciplines : Sciences du Langage et Sciences Sociales, (R. Micheli, ed.), A contrario, 2, n_16, 110-130, 2011.

POINCARÉ, H. La théorie de Maxwell et les oscillations hertziennes, Collection Scientia. Chartre : DURAND, 1899. 80p.

Electricité et optique, I. Les théories de Maxwell et la théorie électromagnétique de la lumière. Leçons professées pendant le second semestre 1888-1889 [en réalité, 1887-1888], rédigées par Jules Blondin, Cours de physique mathématique, Paris, Carré, 1890, ré-éd. revue et augmentée de 1901a.

Electricité et optique, II. Les théories de Helmhotlz et les expériences de Hertz. Leçons professées pendant le second semestre 1889-1890, rédigées par Bernard Brunhes, Cours de physique mathématique, Paris, Carré, 1891, ré-édition revue et augmentée de 1901b.

La science e I'hypothèse. Rueil-Malmaison: La Bohème. 1992. $282 p$.

O valor da ciência. Rio de Janeiro: ContraPonto, 1995. 180p. 
. Science et Méthode. Classics Series. Memphis: BooksLLC®. 2011.

$49 p$.

POSPIECH, G. Teaching the EPR paradox at high school? Physics Education, v. 34, n. 5, 1999.

. Uncertainty and complementarily: the heart of quantum physics.

Physics Education, London, v. 35, n. 6, p. 393-399, 2000.

QUEIROZ, G. R. P. C. Professores artist as-reflexivos de física no ensino médio. 2000. Tese (Doutorado). Pontifícia Universidade Católica do Rio de Janeiro/PUC. Rio de Janeiro. 2000.

REY, A., La Théorie de la physique chez les physiciens contemporains. Paris : Alcan, 1907. 412p.

RIGOTO, R. ; OBARA, A. Distinção entre analogia e metáfora para aplicação do modelo Teaching with analogies por licenciandos de Biologia. Revista Electrónica de Enseñanza de las Ciencias - Vol 10, No 3, 481-498, 2011.

SAMAGAIA, R.; PEDUZZI, L. O. Q. Uma experiência com o projeto Manhattam no Ensino Fundamental. Ciência \& Educação. Bauru, v. 10, n. 2, p. 259-276, 2004.

SAMPIERI, R. H.; COLLADO, C. F.; LUCIO, P. B. Metodologia de pesquisa . 3. ed. São Paulo: McGraw-Hill Interamericana do Brasil Ltda., 2006.

SAUSSURE, F.; Cours de Linguistique Générale. Paris:Payot, 1966.

SEIDENGART, J. Théorie de la connaissance et épistémologie de la physique dans l'œuvre de Cassirer, In: E. Cassirer, De Marbourg à New-York: I'Itinéraire philosophique. Paris : Cerf, coll. "Passages", p. 159-176. mars 1990.

SHINOMIYA, G K. Saberes e Práticas Docentes para a Inovação Curricular: uma análise das práticas da sala de aula. 2013, 168f. Tese (Doutorado em Educação),Faculdade de Educação. Universidade de São Paulo, São Paulo, 2013. 
SILVA et al. Familiaridade de Alunos de Ensino Médio com Situações Análogas. In: V ENCONTRO NACIONAL DE PESQUISA EM EDUCAÇÃO EM CIÊNCIAS, 5., São Paulo. Atas... Bauru: UNESP, 2005.

SILVA, A.C.; ALMEIDA M.J.P. Física Quântica no Ensino Médio: O que dizem as pesquisas. Caderno Brasileiro de Ensino de Física., v. 28, n. 3: p. 624-652, dez. 2011.

SOUZA, V. ; JUSTI, R. ; FERREIRA, P. Analogias Utilizadas no Ensino dos Modelos Atômicos de Thomson e Bohr: Uma Análise Crítica sobre o que os Alunos Pensam a Partir Delas. Investigações em Ensino de Ciências, v.11(1), p.7-28, 2006.

STANNARD, R. Modern physics for the young. Physics Education, Bristol, v.25, n. 3, p. 133, 1990.

TASKER, R.; OSBORNE, R. Science teaching and Science learning. In: OSBORNE, R. \& FREYBERG, P. (Eds.), learning in science: the implication of children's science. Auckland, New Zealand: Heinemann. pp.15-27. 1985.

TERRAZZAN, E. A Inserção da Física Moderna e Contemporânea no Ensino de Física na Escola de 2o Grau. Caderno Catarinense de Ensino de Física, Florianópolis, v. 9, n.3, p. 209-214, dez. 1992.

TOMASELLO, M. The cultural origins of human cognition. Cambridge, MA: Harvard University Press. 1999. 248p.

TREAGUST, D. F.; HARRISON, A. G.; VENVILLE, G. Teaching science effectively with analogies: An approach for pre-service and in-service teacher education. Journal of Science Teacher Education, v.9(1), p.85-101, 1998.

TREAGUST, D. F.; HARRISON, A. G.; VENVILLE, G.; DAGHER, Z. Using an analogical teaching approach to engender conceptual change. International Journal of Science Education, v.18, p.213-229, 1996. 
VENVILLE, G.J. The Focus - Action - Reflection (FAR) Guide - Science Teaching Analogies. IN: HARRISON, A.G.; COLL, R.K. Using Analogies in Middle and Secondary Science Classrooms. Thousand Oaks: Corwin Press. pp. 22-31. 2008.

VILLANI, A.; BAROLLI, E.; CABRAL,T. C. B.; FAGUNDES, M. B. e YAMAZAKI, S. C. Filosofia da Ciência, História da Ciência e Psicanálise: Analogias Para o Ensino de Ciências. Caderno Catarinense de Ensino de Física, v.14,n1: p.37-55, 1997.

VAN DER VEER, R.; VALSINER, J. Understanding Vygotsky: A quest for synthesis. Oxford: Blackwell, 1991.

VYGOTSKY, L. S. Mind in Society: The development of higher psychological processes. Cambridge, MA: Harvard University Press. 1978. 159p.

Plenum. 1987.

The Collected Works of L. S. Vygotsky. Vol1. New York:

A formação social da mente. São Paulo: Martins Fontes, 2007.

$182 \mathrm{p}$.

WALDRIP, B. \& PRAIN, V. Learning from and through representations in science. In B.J. Fraser, K. Tobin \& J. McRobbie (eds.), Second International Handbook of Science Education. Dordrecht: Springer 145-155. 2012.

WERTSCH, J. V. Voices of the mind: A sociocultural approach to mediated action. Cambridge, MA: Harvard University Press. 1991. 169p.

YERRICK, R. K. et al. Social interaction and the use of analogy: an analysis of preservice teacher"s talk during physics inquiry lessons. Journal Of Research In Science Teaching. v.40, n.5. pp.443-463. 2003.

ZANETIC, J. Física Também é Cultura, Tese de doutorado, FEUSP, São Paulo, 1989.

ZEILINGER, A. General Proprieties of Loss-less Beam Splitters in Interferometry. American Journal of Physics 49, 882-3. 1981. 
ZOOK, K. B. Effect of analogical processes on learning and misrepresentation. Educational Psychology Review, 3(1), 41 - 72. 1991. 
APÊNDICE A - Mapa de eventos: Aulas

\begin{tabular}{|c|c|c|c|c|c|c|}
\hline \multicolumn{7}{|c|}{ Aula $01-01 / 04 / 2011$} \\
\hline $\mathbf{N}$ & Início & Fim & Natureza do evento & Tópico & Recursos & Descrição detalhada \\
\hline 1 & $00: 00$ & $04: 29$ & $\begin{array}{l}\text { (Organizativo) Alunos entram na } \\
\text { sala e se instalam. O professor } \\
\text { chama a atenção da turma para o } \\
\text { início da chamada }\end{array}$ & & & \\
\hline 2 & $04: 29$ & $05: 20$ & $\begin{array}{l}\text { (Explicativo) «Lembrete da aula } \\
\text { anterior » (experimento com } \\
\text { laser) }\end{array}$ & & $(\mathrm{V})$ & \\
\hline 3 & $05: 20$ & $08: 46$ & $\begin{array}{l}\text { (E) Apresentação dos principais } \\
\text { modelos atômicos até o modelo } \\
\text { de Rutherford. }\end{array}$ & $(\mathrm{CM})$ & $(\mathrm{V})$ & $\begin{array}{l}\text { Faz uma breve análise histórica dos principais modelos atômicos. } \\
\text { Atribui então uma ideia de evolução, destacando que em certos } \\
\text { contextos os modelos "superados" podem ser utilizados (modelo } \\
\text { de Dalton como base para os modelos utilizados em química) }\end{array}$ \\
\hline 4 & $08: 46$ & $15: 46$ & $\begin{array}{l}\text { (E) O modelo de Rutherford em } \\
\text { detalhes }\end{array}$ & $(\mathrm{CM})$ & $(\mathrm{V})(\mathrm{P})$ & $\begin{array}{l}\text { Explica com detalhes o experimento de Rutherford, e para isso o } \\
\text { professor recorre a desenhos e esquemas feitos no quadro. } \\
\text { Apresenta os limites desse modelo. }\end{array}$ \\
\hline$* 5$ & $15: 46$ & 20:37 & (E) Física quântica, o que é? & $(\mathrm{QE})$ & $(\mathrm{V})(\mathrm{P})(\mathrm{G})$ & $\begin{array}{l}\text { Apresenta a quantização da energia de Planck. Lança mão de } \\
\text { uma analogia (os degraus de uma escada) como elemento } \\
\text { explicativo. }\end{array}$ \\
\hline 6 & $20: 37$ & $26: 31$ & $\begin{array}{l}\text { (E) Modelo atômico de } \\
\text { Rutherford-Bohr }\end{array}$ & $(\mathrm{CM})$ & $(\mathrm{V})(\mathrm{P})$ & Destaca a existência dos níveis de energia do átomo. \\
\hline 7 & $26: 31$ & $31: 31$ & (E) Distribuição eletrônica & $(\mathrm{CM})$ & $(\mathrm{V})(\mathrm{P})$ & $\begin{array}{l}\text { Destaca a notação que será adotada na representação de um } \\
\text { elemento químico. }\end{array}$ \\
\hline 8 & $31: 31$ & $36: 14$ & $\begin{array}{l}\text { (Participativo) Determinar } \mathrm{o} \\
\text { número de prótons e elétrons de }\end{array}$ & & & \\
\hline
\end{tabular}




\begin{tabular}{|l|l}
$48: 19$ & um elemento químico. \\
$52: 31$ & (E) Subníveis de energia \\
(P) Distribuição eletrônica
\end{tabular}




\begin{tabular}{|c|c|c|c|c|c|c|}
\hline \multicolumn{7}{|c|}{ Aula 02-11/03/2011 } \\
\hline $\mathbf{N}$ & Início & Fim & Natureza do evento & Tópico & Recursos & Descrição detalhada \\
\hline 1 & $00: 00$ & $01: 56$ & $\begin{array}{l}\text { (O) Iniciando a aula. Professor } \\
\text { explica a presença da câmera e } \\
\text { fala sobre o projeto FM no ensino } \\
\text { médio. }\end{array}$ & & & $\begin{array}{l}\text { professor passa algumas orientações a respeito das tarefas } \\
\text { passadas para casa. }\end{array}$ \\
\hline 2 & $01: 56$ & $04: 29$ & $\begin{array}{l}\text { (E) Introdução ao estudo de física } \\
\text { moderna. }\end{array}$ & (DOP) & $(\mathrm{V})(\mathrm{T})$ & $\begin{array}{l}\text { O professor destaca a natureza dual da luz. Com a intenção de } \\
\text { envolver os alunos nas discussões que se seguem, o professor } \\
\text { simula uma situação de furto de um pedaço de chocolate. A partir } \\
\text { da presente situção, os convida a pensar como a física pode ser } \\
\text { útil na resolução do referido caso. }\end{array}$ \\
\hline 3 & $04: 29$ & 06:03 & $\begin{array}{l}\text { (Introdutório) Vídeo produzido } \\
\text { pelo professor. }\end{array}$ & & (P) & $\begin{array}{l}\text { Apresentação da edição de um vídeo denominado "CSI-LICEU", } \\
\text { que conta com o professor como um dos atores, dentre o elenco } \\
\text { da série original. O vídeo causa risos e parece atingir seu } \\
\text { objetivo. }\end{array}$ \\
\hline 4 & 06:03 & 20:17 & $\begin{array}{l}\text { (E) Modelos atômicos e as linhas } \\
\text { espectrais }\end{array}$ & $(\mathrm{CM})$ & $(\mathrm{V})(\mathrm{P})$ & $\begin{array}{l}\text { O professor cita os gregos, fala sobre o modelo de Dalton e sobre } \\
\text { o modelo de Thomson (usa a analogia do "pudim de passas" mas } \\
\text { destaca que é mais adequado pensarmos no panetone). A fim de } \\
\text { explicitar o modelo atômico de Rutherford,o professor lança mão } \\
\text { de um vídeo com uma animação. Mostra também os limites de } \\
\text { cada modelo. }\end{array}$ \\
\hline *5 & $20: 17$ & 24:47 & $\begin{array}{l}\text { (P) Simulação da instabilidade do } \\
\text { átomo de Rutherford. }\end{array}$ & $(\mathrm{CM})$ & $(\mathrm{T})$ & $\begin{array}{l}\text { Com um lençol, uma bola de arremesso de peso, e algumas } \\
\text { bolinhas de gude, o professor explica a "analogia prática". Os } \\
\text { alunos são convidados a irem a frente da sala e atuar na } \\
\text { simulação (todos de pé, mas alguns só assistem). }\end{array}$ \\
\hline 6 & $24: 47$ & $35: 13$ & $\begin{array}{l}\text { (E) Modelo atômico de Bohr e o } \\
\text { quantum de energia }[E=h . v]\end{array}$ & $(\mathrm{CM})(\mathrm{QE})$ & $(\mathrm{V})(\mathrm{P})$ & $\begin{array}{l}\text { O professor apresenta o quantum de energia. Explica a } \\
\text { estabilidade do átomo de Bohr via quantização de Planck (uso de } \\
\text { uma animação). }\end{array}$ \\
\hline 7 & $35: 13$ & 45:27 & (E) Espectro eletromagnético & & $(\mathrm{V})(\mathrm{P})$ & Com o auxílio da projeção de um slide o professor apresenta o \\
\hline
\end{tabular}




\begin{tabular}{|l|l|l|l|} 
& & & \\
8 & $45: 27$ & $48: 46$ & (O) Encerramento da aula \\
& & &
\end{tabular}

espectro eletromagnético e dá ênfase ao extrato correspondente a luz visível. Por fim apresenta (brevemente) os espectros de emissão e absorção de um átomo.

O professor dá os últimos avisos enquanto os alunos saem. O professor tira dúvida de duas alunas. Por último indaga se alunos (os que ainda permaneceram na sala) gostaram da aula.

"última fala de uma aluna: - Professor, eu quero saber como, com isso, você vai descobrir quem roubou seu chocolate?". 


\begin{tabular}{|c|c|c|c|c|c|c|}
\hline \multicolumn{7}{|c|}{ Aula 03 - 14/03/2011 } \\
\hline $\mathbf{N}$ & Início & Fim & Natureza do evento & Tópico & Recursos & Descrição detalhada \\
\hline 1 & 00:00 & 01:05 & (O) Iniciando a aula & & & $\begin{array}{l}\text { Professor fala sobre o texto enviado aos alunos que servirá de } \\
\text { base para aula. }\end{array}$ \\
\hline 2 & 01:05 & 08:41 & $\begin{array}{l}\text { (E) Introdução ao efeito } \\
\text { fotoelétrico. }\end{array}$ & $(\mathrm{QE})$ & $(\mathrm{V})(\mathrm{P})$ & $\begin{array}{l}\text { O professor lança mão do espectro eletromagnético a fim de } \\
\text { apresentar em que faixa de frequências ocorre o efeito } \\
\text { fotoelétrico. }\end{array}$ \\
\hline 3 & 08:41 & $14: 38$ & (E) $\mathrm{O}$ que é frequência? & & $(\mathrm{V})(\mathrm{P})$ & $\begin{array}{l}\text { Para tratar o conceito de frequência, o professor recorre ao } \\
\text { movimento circular e em seguida passa ao movimento } \\
\text { ondulatório. Destaca também a relação entre a energia associada } \\
\text { a uma onda eletromagnética e sua frequência. }\end{array}$ \\
\hline 4 & $14: 38$ & 23:26 & (E) $\mathrm{O}$ fóton e sua energia $[\mathrm{E}=\mathrm{h} . \mathrm{v}]$. & $(\mathrm{QE})(\mathrm{CCL})$ & $(\mathrm{V})(\mathrm{P})$ & $\begin{array}{l}\text { O professor recorre a questão da radiação do corpo negro para } \\
\text { reforçar a quantização de Planck. }\end{array}$ \\
\hline $5^{*}$ & $23: 26$ & $24: 43$ & $\begin{array}{l}\text { (E) Comparando a energia de } \\
\text { dois fótons (um azul e outro } \\
\text { vermelho). }\end{array}$ & $(\mathrm{CCL})$ & $(\mathrm{V})(\mathrm{G})$ & O professor usa como analogia um jogo de sinuca. \\
\hline $6^{*}$ & $24: 43$ & $28: 21$ & (E) Quantização da energia. & $(\mathrm{QE})$ & $(\mathrm{V})$ & $\begin{array}{l}\text { O professor lança mão de uma sequência de analogias a fim de } \\
\text { aproximar os alunos da ideia de quantização presente no efeito } \\
\text { fotoelétrico. }\end{array}$ \\
\hline 7 & $28: 21$ & $34: 20$ & $\begin{array}{l}\text { (E) Algumas aplicações do efeito } \\
\text { fotoelétrico. }\end{array}$ & $(\mathrm{QE})(\mathrm{CCL})$ & $(\mathrm{V})$ & $\begin{array}{l}\text { Alguns exemplos como os foto sensores presentes em portas de } \\
\text { shoppings e células fotoelétricas usadas no armazenamento de } \\
\text { energia elétrica são apresentados pelo professor. }\end{array}$ \\
\hline 8 & $34: 20$ & $37: 26$ & $\begin{array}{l}\text { (O) Encerramento da aula } \\
\text { [ }\end{array}$ & & & O professor apresenta as atividades da próxima aula. \\
\hline
\end{tabular}




\begin{tabular}{|c|c|c|c|c|c|c|}
\hline \multicolumn{7}{|c|}{ Aula 04 - 14/03/2011 (A) } \\
\hline $\mathbf{N}$ & Início & Fim & Natureza do evento & Tópico & Recursos & Descrição detalhada \\
\hline 1 & $00: 00$ & $00: 45$ & (O) Iniciando a aula & & & Descreve as atividades do dia \\
\hline$* 2$ & $00: 45$ & $15: 12$ & (E) Energia dos estados quânticos & $(\mathrm{QE})$ & $(\mathrm{V})(\mathrm{P})$ & $\begin{array}{l}\text { O professor calcula os níveis de energia dos primeiros estados } \\
\text { para o átomo de hidrogênio e compara com a energia do fóton da } \\
\text { luz azul. } \\
\text { A fim de reforçar a ideia da quantização dos estados o professor } \\
\text { lança mão de uma analogia (opções de andar no elevador de um } \\
\text { prédio). }\end{array}$ \\
\hline 3 & $15: 12$ & $18: 48$ & $\begin{array}{lccc}(\mathrm{O}) /(\mathrm{E}) & \text { Orientações } & \text { para } & \text { a } \\
\text { atividade que se segue. } & & \end{array}$ & $(\mathrm{QE})$ & $(\mathrm{T})$ & $\begin{array}{l}\text { O professor sugere a construção de um jogo de tabuleiro. Apesar } \\
\text { das orientações sugerirem um evento de natureza organizativa, tal } \\
\text { evento se apresenta como tendo uma natureza "híbrida". Afinal, } \\
\text { durante a orientação da atividade o professor reforça o conceito } \\
\text { de quantização da energia, outrora apresentado. }\end{array}$ \\
\hline 4 & $18: 48$ & $37: 41$ & (P)/(E) Início da atividade & $(\mathrm{QE})$ & $(\mathrm{T})$ & $\begin{array}{l}\text { Construção dos dados e do tabuleiro. Início da atividade. Mais } \\
\text { um evento de natureza "híbrida". Durante a explicação dada a um } \\
\text { grupo, o professor lança mão de uma analogia entre os fótons e } \\
\text { laranjas que estão a venda na feira. }\end{array}$ \\
\hline 5 & & $37: 41$ & [Fim da gravação] & & & \\
\hline
\end{tabular}


Aula 05 - 09/11/2012 - $1^{\circ}$ vídeo

\begin{tabular}{|c|c|c|c|c|c|c|}
\hline $\mathbf{N}$ & Início & Fim & Natureza do evento & Tópico & Recursos & Descrição detalhada \\
\hline 1 & $00: 00$ & $17: 31$ & (E) Revisão - Efeito fotoelétrico. & (CCL) & $(\mathrm{V})(\mathrm{P})$ & $\begin{array}{l}\text { Professor dialoga com os alunos a fim de contrastar as previsões } \\
\text { da teoria clássica com os resultados do efeito fotoelétrico. Uso dð7 } \\
\text { simulador. }\end{array}$ \\
\hline 2 & $17: 31$ & 41:11 & (E) Modelo corpuscular da luz. & (CCL) (DOP) & $(\mathrm{V})(\mathrm{P})$ & A luz como partícula e a função trabalho. \\
\hline 3 & 41:11 & $53: 15$ & (E) A natureza da luz. & (CCL) (DOP) & (V) (P) & $\begin{array}{l}\text { Discussão a respeito da natureza da luz. Os fenômenos luminosos } \\
\text { e as interpretações, corpuscular e ondulatória, da luz. }\end{array}$ \\
\hline \multicolumn{7}{|c|}{ Aula $05-09 / 11 / 2012-2^{\circ}$ vídeo } \\
\hline $\mathbf{N}$ & Início & Fim & Natureza do evento & Tópico & Recursos & Descricão detalhada \\
\hline 4 & 00:00 & 01:58 & 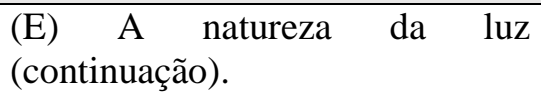 & & & \\
\hline 5 & 01:58 & 03:49 & $\begin{array}{l}\text { (O) Explicação da atividade da } \\
\text { próxima aula. }\end{array}$ & & & $\begin{array}{l}\text { O professor apresenta como atividade para próxima aula a } \\
\text { montagem do interferômetro de Mach-Zehnder. }\end{array}$ \\
\hline 6 & 03:49 & 06:39 & $\begin{array}{l}\text { (E) Apresentação inicial do } \\
\text { interferômetro de Mach-Zehnder. }\end{array}$ & $(\mathrm{CCL})(\mathrm{DOP})$ & $(\mathrm{V})(\mathrm{P})$ & Apresenta o simulador do interferômetro. \\
\hline 7 & $06: 39$ & 07:06 & (O) Fechamento da aula. & & & \\
\hline
\end{tabular}

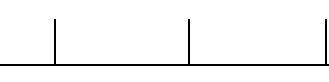


Aula 06 - 30/11/2012

\begin{tabular}{|c|c|c|c|c|c|c|}
\hline $\mathbf{N}$ & Início & Fim & Natureza do evento & Tópico & Recursos & Descrição detalhada \\
\hline$* 1$ & $00: 00$ & $04: 32$ & 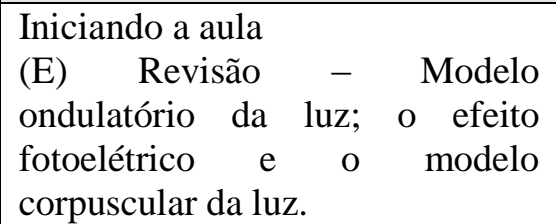 & $\begin{array}{l}(\mathrm{CCL})(\mathrm{DOP}) \\
(\mathrm{QE})\end{array}$ & $(\mathrm{V})(\mathrm{P})$ & $\begin{array}{l}\text { Retoma discussões de aulas anteriores nas quais destaca a } \\
\text { frequência da onda, e não a amplitude, como elemento } \\
\text { fundamental "causador" do efeito fotoelétrico. }\end{array}$ \\
\hline 2 & $04: 32$ & $06: 10$ & (E) A natureza da luz. & $(\mathrm{CCL})(\mathrm{DOP})$ & $(\mathrm{V})$ & \\
\hline 3 & $06: 10$ & $21: 34$ & $\begin{array}{l}\text { (E) O interferômetro de Mach- } \\
\text { Zehnder - Laser }\end{array}$ & $(\mathrm{CCL})(\mathrm{DOP})$ & $(\mathrm{V})(\mathrm{P})$ & $\begin{array}{l}\text { A partir do simulador, o professor discute o conceito de } \\
\text { interferência. } \\
\text { Com o esquema desenhado no quadro, o professor destaca os } \\
\text { componentes do interferômetro. } \\
\text { Discussão a respeito da figura de interferência formada no } \\
\text { anteparo. }\end{array}$ \\
\hline 4 & $21: 34$ & $29: 35$ & (E) Experimento monofotônico & $(\mathrm{CCL})(\mathrm{DOP})$ & $(\mathrm{V})(\mathrm{P})(\mathrm{G})$ & $\begin{array}{l}\text { Destaque para figura de interferência no experimento } \\
\text { monofotônico. } \\
\text { O professor usa gestos que apontam uma forma senoidal toda } \\
\text { vez que ele menciona a luz como onda. }\end{array}$ \\
\hline 5 & $29: 35$ & $30: 34$ & (O) Encerramento da aula & & & $\begin{array}{l}\text { Apresenta algumas interpretações da Mecânica Quântica como } \\
\text { assunto da próxima aula. }\end{array}$ \\
\hline
\end{tabular}




\begin{tabular}{|c|c|c|c|c|c|c|}
\hline \multicolumn{7}{|c|}{ Aula $07-30 / 11 / 2012$} \\
\hline $\mathbf{N}$ & Início & Fim & Natureza do evento & Tópico & Recursos & Descrição detalhada \\
\hline 1 & $00: 00$ & $02: 55$ & (O) Iniciando a aula & & & Explica a condução da aula e introduz o tema. \\
\hline 2 & $02: 55$ & $05: 48$ & $\begin{array}{l}\text { (E) Interpretação ondulatória para } \\
\text { o experimento monofotônico. }\end{array}$ & (CCL) (DOP) & $(\mathrm{V})(\mathrm{P})$ & *O professor usa a analogia do fóton como uma bolinha. \\
\hline 3 & $05: 48$ & $08: 08$ & (E) Interpretação corpuscular. & $(\mathrm{CCL})$ & $(\mathrm{V})(\mathrm{P})$ & Apresentação do fóton como partícula indivisível. \\
\hline$* 4$ & $08: 08$ & $11: 44$ & (E) Interpretação dualista realista. & (CCL) (DOP) & $(\mathrm{V})(\mathrm{P})$ & *Apresenta a analogia do surfista. \\
\hline 5 & $11: 44$ & $15: 56$ & $\begin{array}{l}\text { (E) Interpretação } \quad \text { da } \\
\text { complementaridade. }\end{array}$ & (CCL) (DOP) & $(\mathrm{V})(\mathrm{P})$ & Destaca que o arranjo experimental define o resultado. \\
\hline 6 & $15: 56$ & $22: 59$ & $\begin{array}{l}\text { (O) Orientação para a atividade } \\
\text { que se segue. }\end{array}$ & & & O professor distribui o material e explica a atividade. \\
\hline 7 & $22: 59$ & $53: 11$ & (P) Atividade em sala & & & $\begin{array}{l}\text { Os alunos respondem algumas questões a respeito das } 4 \\
\text { interpretações da Mecânica Quântica apresentadas pelo professor. }\end{array}$ \\
\hline
\end{tabular}


Aula 08 - 22/11/2012

\begin{tabular}{|c|c|c|c|c|c|c|}
\hline $\mathbf{N}$ & Início & Fim & Natureza do evento & Tópico & Recursos & Descrição detalhada \\
\hline 1 & $00: 00$ & $01: 27$ & (O) Iniciando a aula & & & $\begin{array}{l}\mathrm{O} \text { professor abre a aula explicando as atividades do dia e faz } \\
\text { referências às aulas anteriores. }\end{array}$ \\
\hline 2 & $01: 27$ & $02: 47$ & (E) A luz como onda & & $(\mathrm{V})(\mathrm{P})$ & Breve histórico. \\
\hline 3 & $02: 47$ & $08: 31$ & $\begin{array}{l}\text { (E) Debate sobre a natureza da } \\
\text { luz. }\end{array}$ & $(\mathrm{CCL})(\mathrm{DOP})$ & & $\begin{array}{l}\text { Ainda numa perspectiva histórica, destaque ao "debate" entre } \\
\text { Newton e Huygens e a experiência da dupla fenda de Young. }\end{array}$ \\
\hline$* 4$ & $08: 31$ & $11: 45$ & (E) Efeito fotoelétrico. & $(\mathrm{QE})$ & $(\mathrm{V})(\mathrm{G})$ & $\begin{array}{l}\text { O professor gesticula a fim de representar o fenômeno da } \\
\text { ressonância em uma ponte. } \\
\text { Discute as incompatibilidades do efeito fotoelétrico com o } \\
\text { modelo ondulatório. } \\
\text { *Analogia entre a amplitude da onda luminosa e a intensidade do } \\
\text { vento no fenômeno de ressonância mencionado. }\end{array}$ \\
\hline 5 & $11: 45$ & $27: 13$ & $\begin{array}{l}\text { (E) A natureza da luz a partir do } \\
\text { efeito fotoelétrico. }\end{array}$ & (CCL) (DOP) & (V) & $\begin{array}{l}\text { Questões levantadas pelos alunos desviam a discussão do tema. O } \\
\text { professor opta por deixar a condução da aula sob a condução das } \\
\text { questões. }\end{array}$ \\
\hline 6 & $27: 13$ & $32: 57$ & $\begin{array}{l}\text { (E) } \mathrm{O} \text { interferômetro de Mach- } \\
\text { Zehnder. }\end{array}$ & (CCL) & $(\mathrm{V})(\mathrm{P})$ & Apresentação do simulador. \\
\hline 7 & $32: 57$ & $35: 16$ & $\begin{array}{l}\text { (O) Orientação para a atividade } \\
\text { que segue. }\end{array}$ & & & \\
\hline & & $36: 54$ & [FIM DA GRAVAÇAO] & & & \\
\hline
\end{tabular}

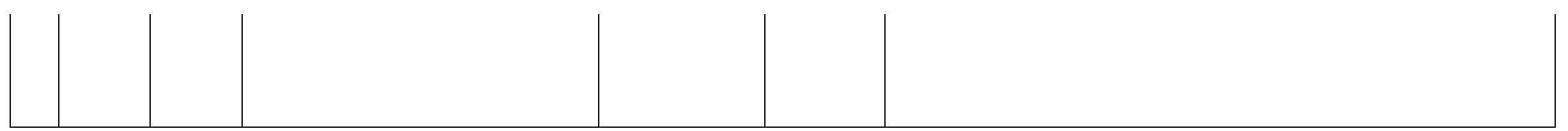




\section{APÊNDICE B - Quadros dos Episódios Analisados}

\begin{tabular}{|c|c|c|c|}
\hline \multicolumn{4}{|c|}{ Episódio 01 (MAT - 01 - 01042011- 05) - Física Quântica, o que é? } \\
\hline $\mathbf{S}$. & No. Do turno (Sujeito) Transcrição & Ações no turno & $\begin{array}{l}\text { Identificação de elementos da } \\
\text { analogia. }\end{array}$ \\
\hline 1 & $\begin{array}{l}\mathbf{1}(\mathbf{P})(. . .) \text { e graças a Max Planck, a atual física clássica } \\
\text { basicamente desmoronou (+++)por quê? porque ele veio } \\
\text { com uma nova ideia uma nova (++) situação de:: uma } \\
\text { proposta nova de trabalho(+) que é algo assim muito } \\
\text { absurdo (+) mas que funcionava (++) inclusive Max } \\
\text { Planck foi basicamente o pai da física quântica (++) e o } \\
\text { que é a física quântica?/ }\end{array}$ & $\begin{array}{l}\text { O professor se posiciona no meio do } \\
\text { quadro e por meio de uma narrativa com } \\
\text { viés histórico aponta para uma certa } \\
\text { incoerência da proposta de Planck para o } \\
\text { átomo. }\end{array}$ & \\
\hline 2 & 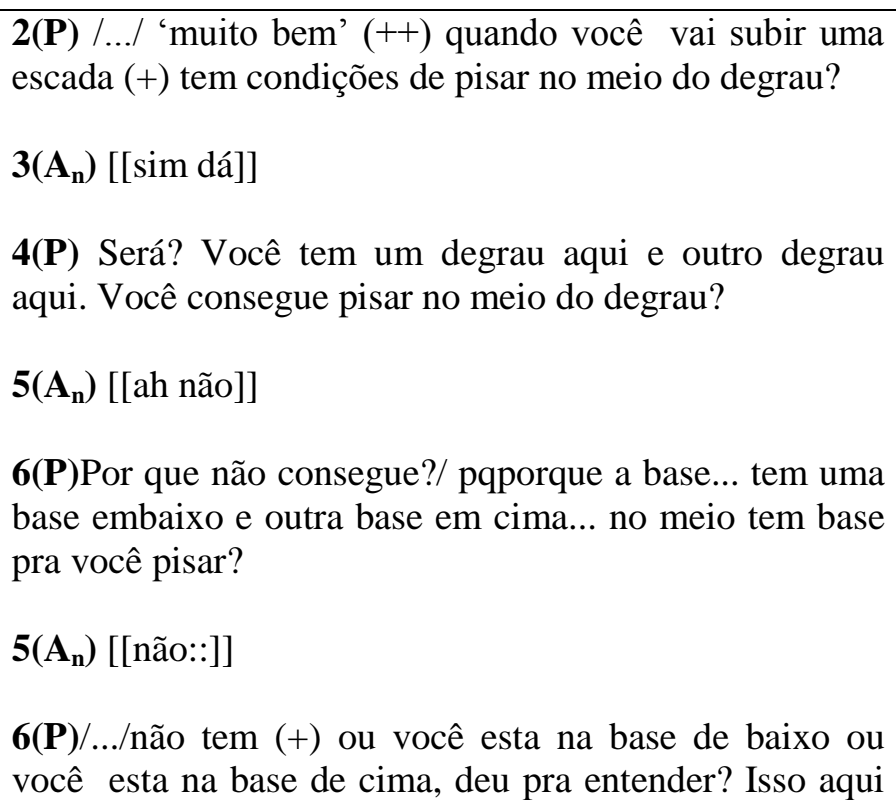 & $\begin{array}{l}\text { Na tentativa de explicar o conceito de } \\
\text { quantização de Planck, o professor lança } \\
\text { mão de uma analogia (subindo uma } \\
\text { escada degrau por degrau). Ao perceber } \\
\text { que de início os alunos não } \\
\text { compreenderam, o professor recorre a } \\
\text { outros recursos representativos, a saber, } \\
\text { gestual e pictórico. Ele gesticula } \\
\text { simulando os degraus de uma escada e } \\
\text { em seguida desenha uma escada no } \\
\text { quadro. }\end{array}$ & $\begin{array}{l}\text { Cada degrau da proposta escada } \\
\text { representa (é análogo) aos níveis de } \\
\text { energia dos elétrons em um átomo } \\
\text { qualquer. Parece que os pés } \\
\text { representados no desenho dos } \\
\text { degraus da escada representam os } \\
\text { elétrons, mas tal detalhe não é } \\
\text { esclarecido pelo professor. }\end{array}$ \\
\hline
\end{tabular}




\begin{tabular}{|c|c|c|c|}
\hline & $\begin{array}{l}\text { oh! } \\
\text { Você vai pisar no degrau... ou você coloca o seu pezinho } \\
\text { aqui ou você coloca o seu pezinho aqui }(+) \text { certo!? (+) } \\
\text { dá pra pisar no meio? } \\
7\left(\mathbf{A}_{\mathbf{n}}\right)[[\text { não::]] }\end{array}$ & & \\
\hline 3 & $\begin{array}{l}\text { 8(P) /.../ essa (+) a grosso modo era o princípio da física } \\
\text { quântica }(++) \text { o que? }(+) \text { que não }(++) \text { que existem }(+) \\
\text { eh:: (+) estados discretos de energia }(+) \text { não dá pra você } \\
\text { ter de qualquer forma a energia }(++) \text { principalmente } \\
\text { quando nós tratamos a nível atômico (+) } \\
\text { À nível atômico, inclusive a física quântica, é o...é a } \\
\text { grande precursora, por exemplo desse tipo de lâmpada } \\
\text { aqui (aponta para o teto )... as lâmpadas fluorescentes, } \\
\text { Quem, pqporque, quando você pega o átomo e excita de } \\
\text { acordo com uma energia esse átomo ele pula de um } \\
\text { degrau para o outro. Ele se excita e vai para o outro } \\
\text { degrau. É claro que tem que ser uma quantidade x, } \\
\text { exatinha. Quando você libera, ele libera a luz. É assim... } \\
\text { Então... esse é o precursor da física quântica, Max } \\
\text { Planck. Aonde as energias vem emmmmmmm... pacotes } \\
\text { discretos. Esse pacote Quantum., não é? }\end{array}$ & $\begin{array}{l}\text { O professor gesticula apontando para o } \\
\text { desenho dos degraus da escada feito no } \\
\text { quadro, assim como aponta para o teto } \\
\text { indicando a lâmpada fluorescente. }\end{array}$ & \\
\hline 4 & $\begin{array}{l}\text { 9(P) Muito bem, então o que Bohr previu? (+++). } \\
\text { Previu sim a mesma coisa que Rutherford havia dito. } \\
\text { Que existe uma região nuclear e que existe os elétrons, e } \\
\text { circulam o núcleo. }\end{array}$ & $\begin{array}{l}\text { O professor volta ao quadro e apaga o } \\
\text { desenho feito anteriormente. Ha uma } \\
\text { pausa até que esta ação seja completada. } \\
\text { Em seguida ele representa no quadro um } \\
\text { modelo planetário. }\end{array}$ & \\
\hline
\end{tabular}




\begin{tabular}{|c|c|c|c|}
\hline & $\begin{array}{l}\text { 10(P) Mas, porem, contudo, todavia, esses elétrons } \\
\text { tem orbitas diferentes, estão lembrando disso agora? } \\
\text { Orbitas discretas, lembram disso? O que é que vocês } \\
\text { lembram disso? } \mathrm{O} \mathrm{P}_{1} \text { deve ter trabalhado com vocês } \\
\text { isso.... Não é? E eu trabalhei com alguns aqui.. eu dei, eu } \\
\text { dei sim, pro } \mathrm{A}_{1} \text {, pro } \mathrm{A}_{2} \text { eu dei, com a } \mathrm{A}_{3} \text { Tb eu trabalhei } \\
\ldots \text { no primeiro ano Química, lembram? Não lembram } \\
\text { nem o que comeram no almoço, NE? ( conversa com } \\
\text { alunos a respeito de ter lecionado Química ou física para } \\
\text { alguns alunos no } 1^{\circ} \text { ano).. } \\
\text { Não.. dei Física e Química para uma turma... Bem, acho } \\
\text { que não foi pra vocês não... }\end{array}$ & $\begin{array}{l}\text { O professor interrompe } \\
\text { momentaneamente a discussão sobre o } \\
\text { tema para conversar com alguns alunos } \\
\text { a respeito de aulas de anos anteriores. }\end{array}$ & \\
\hline 5 & $\begin{array}{l}\mathbf{1 1}(\mathbf{P}) \text { O que é isso? É o modelo que mais utilizamos... É } \\
\text { o modelo atual? Naoooo } \\
\text { O modelo mais conhecido hoje, o que ta... a nível } \\
\text { científico não é esse mas a nível de escolaridade, o que } \\
\text { vamos trabalhar em sala de aula é esse aqui. É o } \\
\text { chamado de modelo de Rutherford/ Bohr. }\end{array}$ & $\begin{array}{l}\text { O professor aponta para o modelo } \\
\text { desenhado no quadro a fim de concluir } \\
\text { com os alunos que não é este o modelo } \\
\text { atômico "aceito" atualmente. }\end{array}$ & \\
\hline
\end{tabular}


Episódio 02 (MAT - 02 - 11032011- 05) - Instabilidade do átomo de Rutherford

\begin{tabular}{|c|c|c|c|}
\hline S. & No. Do turno (Sujeito) Transcrição & Ações no turno & Identificação de elementos da analogia. \\
\hline 1 & $\begin{array}{l}\mathbf{1}(\mathbf{P}) \text { Eu preciso de platéia, e eu preciso de } \\
\text { auxiliares ... deixa eu pegar um cara bem } \\
\text { forte pra me ajudar. } \\
\mathbf{2}\left(\mathbf{A}_{1}\right) \text { Vai lá } \mathrm{A}_{4} \text { ! }\end{array}$ & $\begin{array}{l}\text { O professor caminha até o final da sala a } \\
\text { fim de pegar o material que será usado na } \\
\text { encenação. }\end{array}$ & \\
\hline 2 & 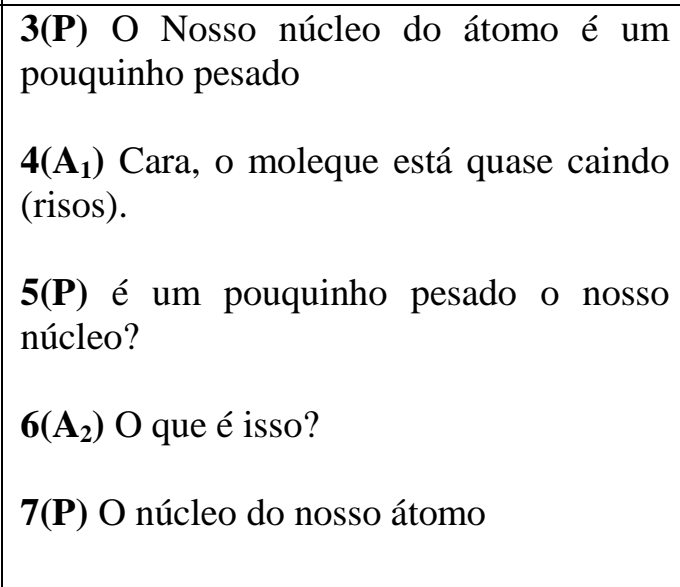 & $\begin{array}{l}\text { O professor empresta a bola de ferro a } \\
\text { um aluno que a segura. Em seguida ele a } \\
\text { faz passar aos demais colegas. }\end{array}$ & $\begin{array}{l}\text { A bola de ferro é o análogo do núcleo. } \\
\text { Reforço da analogia (bola de ferro como } \\
\text { análogo do núcleo). }\end{array}$ \\
\hline 3 & $\begin{array}{l}\text { 8(P) Isso aqui vai simular o nosso campo } \\
\text { eletrônico, a nuvem onde o elétron está. }\end{array}$ & O professor destaca o lençol. & $\begin{array}{l}\text { O lençol é o análogo do que o professor } \\
\text { chama de campo eletrônico. }\end{array}$ \\
\hline 4 & $\begin{array}{l}\text { 9(P) Preciso da ajuda de vocês. Segura } \\
\text { aqui, por favor, você também... os outros } \\
\text { vão ajudar. Vocês precisam ficar de pé } \\
\text { pra assistir, gente. Pega aqui na ponta, } \\
\text { você, vocês... vem cá gente, ajuda! } \\
\text { Preciso de mais gente ... a gente precisa }\end{array}$ & $\begin{array}{l}\text { O professor estica o lençol com a ajuda de } \\
\text { alguns alunos. Na verdade ele não espera } \\
\text { a manifestação de voluntários, antes ele } \\
\text { distribui as pontas do lençol a quatro } \\
\text { alunos. Em seguida ele convida os alunos } \\
\text { a se levantarem e se posicionarem em }\end{array}$ & \\
\hline
\end{tabular}




\begin{tabular}{|c|c|c|c|}
\hline & esticar o pano, aqui ó. & $\begin{array}{l}\text { torno do lençol, assim ele conta com mais } \\
\text { alunos posicionados em diversas partes } \\
\text { das extremidades do lençol para deixá-lo } \\
\text { o mais plano possível. }\end{array}$ & \\
\hline 5 & $\begin{array}{l}\text { 10(P) Cadê o nosso núcleo? O dono do } \\
\text { núcleo vem cá. Estica bem o pano, bem } \\
\text { esticado, bem esticado ... Os outros } \\
\text { fiquem em pé pra assistir. } \\
\text { 11(A) Professor, pode subir na cadeira? } \\
\text { 12(P) O núcleo aqui, pode! } \\
\text { 13(P) O que acontece quando uma coisa } \\
\text { muito pesada entra num campo como } \\
\text { esse? } \\
\mathbf{1 4 ( P )} \text { Deforma o campo, ta? }\end{array}$ & $\begin{array}{l}\text { O professor coloca a bola no meio do } \\
\text { lençol que é esticado pelos alunos e esta } \\
\text { causa neste uma deformação }\end{array}$ & $\begin{array}{l}\text { O lençol deformado pela bola de ferro } \\
\text { representa a alteração das propriedades do } \\
\text { campo devido a presença do núcleo. }\end{array}$ \\
\hline 6 & $\begin{array}{l}\text { 15(P) Isso aqui dá pra gente explicar } \\
\text { também como funciona a gravidade. } \\
\text { Gravidade, ela é a deformação do espaço } \\
\text { tempo causado pela presença de massa, } \\
\text { ta? } \\
\text { 16(P) Pra nós na física clássica depois de } \\
\text { um segundo vem o que? Outro segundo, e } \\
\text { depois de outro segundo mais um } \\
\text { segundo. Na física moderna, na } \\
\text { relatividade é assim: depois de um } \\
\text { segundo pode não vir nada ou podem vir } \\
\text { vários segundos. Depende pra onde você }\end{array}$ & $\begin{array}{l}\text { O professor tenta fazer um "link" com a } \\
\text { teoria da Relatividade Geral. }\end{array}$ & $\begin{array}{l}\text { O lençol deformado representa a alteração } \\
\text { geométrica do espaço tempo devido a } \\
\text { presença de massa. }\end{array}$ \\
\hline
\end{tabular}




\begin{tabular}{|c|c|c|c|}
\hline & $\begin{array}{l}\text { vai... mas vamos ficar no campo } \\
\text { eletrônico que tá bom. }\end{array}$ & & \\
\hline 7 & 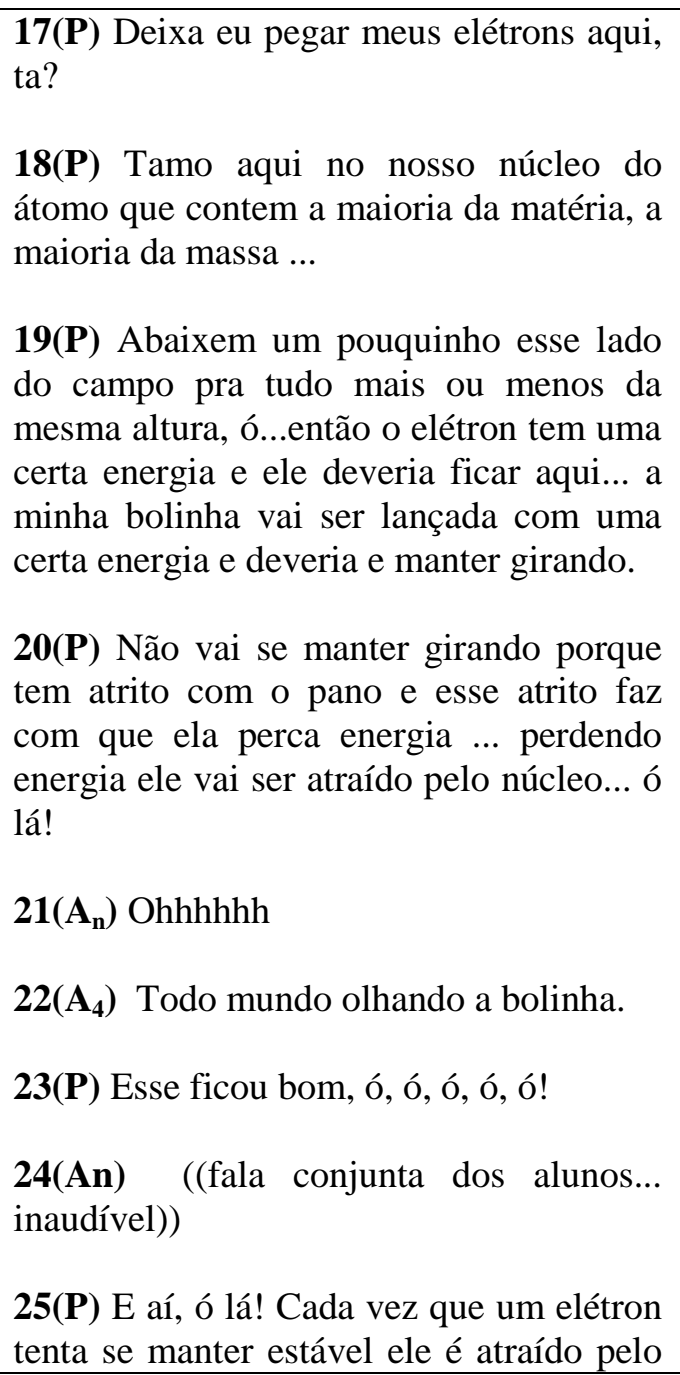 & $\begin{array}{l}\text { O professor orienta os alunos quanto a } \\
\text { "boa" posição do lençol. Em seguida ele } \\
\text { arremessa as bolinhas de gude uma a uma } \\
\text { tecendo comentários a respeito de seu } \\
\text { movimento. } \\
\text { Nesse momento há interação entre } \\
\text { professor e alunos assim como entre } \\
\text { alunos e o material representativo (lençol, } \\
\text { bola de ferro, bolinhas de gude, } \\
\text { deformação do lençol, movimento das } \\
\text { bolinhas,...) } \\
\text { As falas do professor são sempre } \\
\text { enfatizadas por meio de gestos. }\end{array}$ & $\begin{array}{l}\text { As bolinhas de gude são os análogos do } \\
\text { elétrons. O atrito é identificado com a } \\
\text { emissão de energia de uma carga } \\
\text { acelerada. }\end{array}$ \\
\hline
\end{tabular}




\begin{tabular}{|c|c|c|c|}
\hline & $\begin{array}{l}\text { núcleo pois ele está perdendo energia. E } \\
\text { uma hora o núcleo engole o cara. As } \\
\text { vezes engole até rápido demais. } \\
\mathbf{2 6}\left(\mathbf{A}_{\mathbf{n}}\right)((\text { risos dos alunos }))\end{array}$ & & \\
\hline 8 & 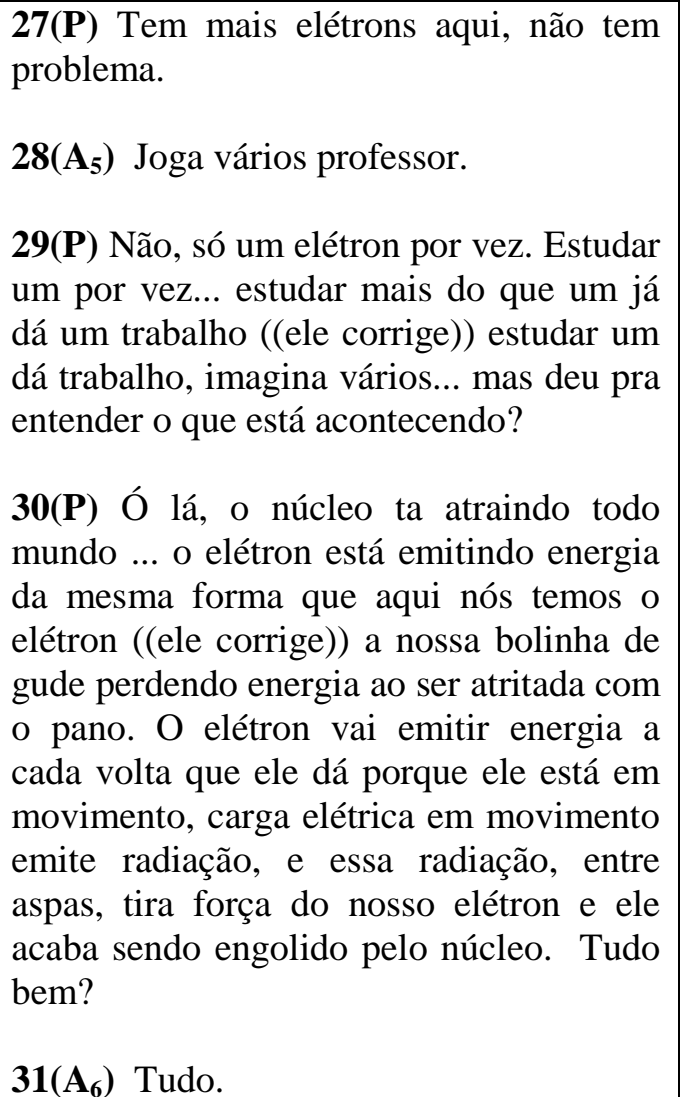 & $\begin{array}{l}\text { O professor enfatiza que o movimento } \\
\text { em espiral das bolinhas de gude } \\
\text { corresponde ao movimento dos elétrons } \\
\text { em torno do núcleo positivamente } \\
\text { carregado. Dessa forma ele busca explicar } \\
\text { o porquê da "fragilidade" do modelo } \\
\text { atômico de Rutherford. } \\
\text { O professor enfatiza com gestos quando } \\
\text { fala "entre aspas". }\end{array}$ & $\begin{array}{l}\text { O movimento em espiral das bolinhas de } \\
\text { gude na superfície do lençol com a bola } \\
\text { de ferro no centro é análogo ao } \\
\text { movimento dos elétrons em torno do } \\
\text { núcleo segundo a leitura clássica do } \\
\text { átomo de Rutherford. }\end{array}$ \\
\hline
\end{tabular}




\begin{tabular}{|l|l|l|l|}
\hline $\begin{array}{l}\text { 32(P) Deu pra entender o movimento? } \\
\mathbf{3 3}\left(\mathbf{A}_{\mathbf{6}}\right) \text { Deu. } \\
\begin{array}{l}\mathbf{3 4}(\mathbf{P}) \text { Podem fechar o meu pano. Meu } \\
\text { campo eletrônico. }\end{array}\end{array}$ & \\
\hline
\end{tabular}




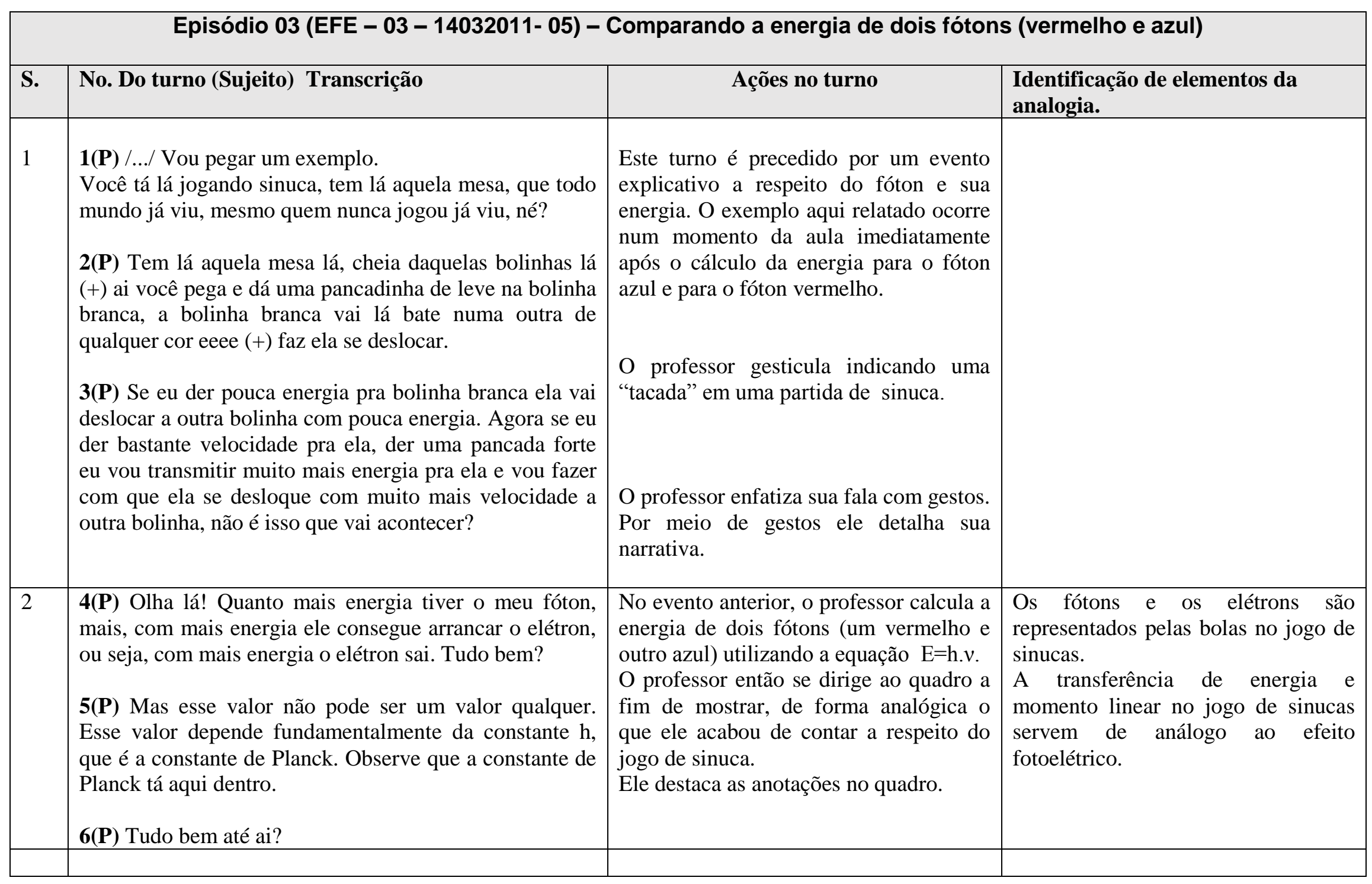


Episódio 04 (EFE - 03 - 14032011- 06) - Quantização da energia no efeito fotoelétrico

\begin{tabular}{|c|c|c|c|}
\hline S. & No. Do turno (Sujeito) Transcrição & Ações no turno & $\begin{array}{l}\text { Identificação de elementos da } \\
\text { analogia. }\end{array}$ \\
\hline 1 & $\begin{array}{l}\text { 1(P) Jogo de tabuleiro (+) a gente explicou na aula } \\
\text { passada, vamos explicar de novo. }\end{array}$ & $\begin{array}{l}\text { O professor remete a uma discussão } \\
\text { ocorrida na aula anterior e a recupera. }\end{array}$ & \\
\hline 2 & $\begin{array}{l}\mathbf{2}(\mathbf{P}) \text { Qual o jogo mesmo que vocês falaram?. } \\
\mathbf{3}\left(\mathbf{A}_{1}\right) \text { Banco imobiliário } \\
\mathbf{4}\left(\mathbf{A}_{2}\right) \text { War } \\
\mathbf{5 ( P )} \text { Banco imobiliário, War não porque o War não tem } \\
\text { aqueles joguinhos lá, né? ((professor gesticula indicando } \\
\text { uma pecinha que se move nas casas de um tabuleiro)). }\end{array}$ & $\begin{array}{l}\text { Momento em que o professor discute } \\
\text { com os alunos o modelo de jogo de } \\
\text { tabuleiro mais adequado a sua analogia. }\end{array}$ & \\
\hline 3 & $\begin{array}{l}\text { 6(P) Vamos lá! O jogo de tabuleiros. } \\
\text { Ai a gente tem lá as pecinhas lá pra pular, tem as } \\
\text { casinhas pra pular e tem o jogo de dados. } \\
7(\mathbf{P}) \text { Você joga o seu dado e dá lá o número 3, o que } \\
\text { você faz? UM, DOIS, TRÊS ((gesticula)). Joga os dados } \\
\text { novamente e sai dois. UM, DOIS. }\end{array}$ & $\begin{array}{l}\text { Retoma a questão do tabuleiro } \\
\text { anteriormente proposta. A medida que } \\
\text { ele não dispõe de um jogo "físico" para } \\
\text { sua ilustração, o professor recorre aos } \\
\text { gestos a fim de caracterizar o tipo de } \\
\text { jogo de tabuleiros ao qual ele se refere. }\end{array}$ & \\
\hline 4 & $\begin{array}{l}\text { 8(P) Por que? O número que sai nos dados é a energia, é } \\
\text { o combustível ((enfatiza com gestos, bate com uma mão } \\
\text { na outra)) que você tá dando pra sua peça pra ela pular } \\
\text { tantas casas. }\end{array}$ & $\begin{array}{l}\text { Representação mímica do jogo de } \\
\text { tabuleiros. }\end{array}$ & $\begin{array}{l}\text { O número que resulta de um } \\
\text { lançamento dos dados no jogo de } \\
\text { tabuleiros tratado pelo professor } \\
\text { representa a quantidade de energia } \\
\text { dada por um fóton ao elétron. }\end{array}$ \\
\hline
\end{tabular}




\begin{tabular}{|c|c|c|c|}
\hline 5 & 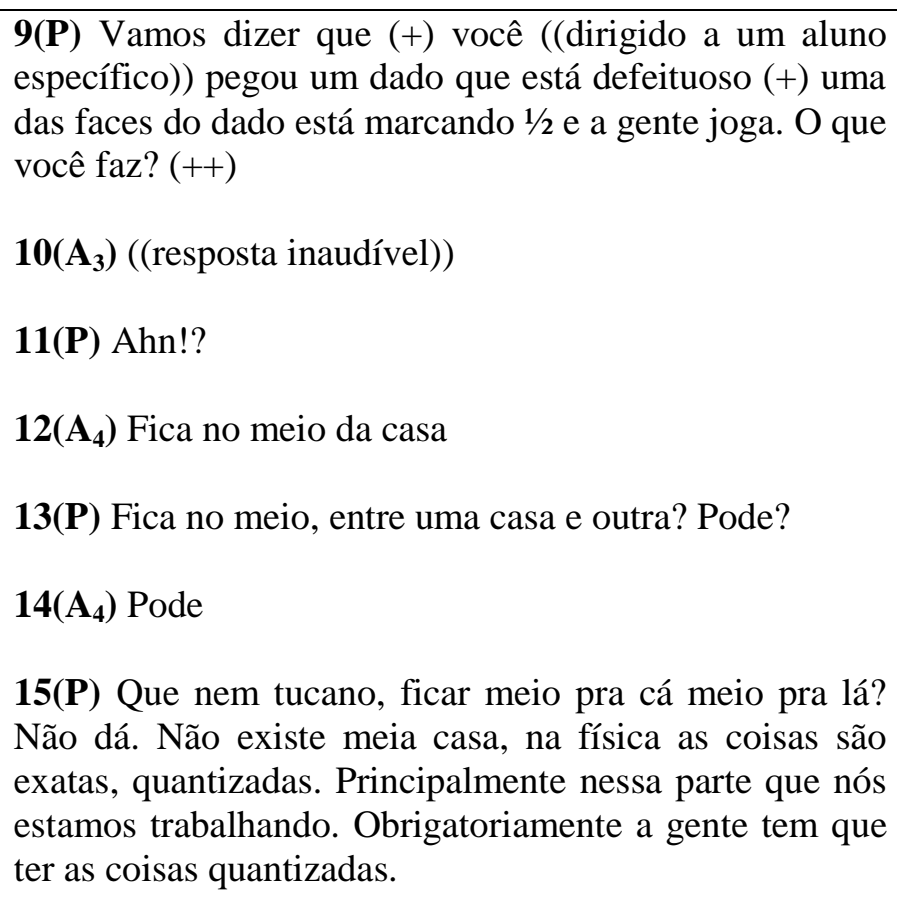 & $\begin{array}{l}\text { Com base nas características do jogo de } \\
\text { tabuleiro em questão, o professor cria } \\
\text { uma situação atípica a fim de provocar a } \\
\text { reação dos alunos. }\end{array}$ & $\begin{array}{l}\text { O dado defeituosos busca representar } \\
\text { por absurdo a ideia clássica de } \\
\text { continuidade da energia. }\end{array}$ \\
\hline 6 & $\begin{array}{l}\text { 16(P)Einstein observou isso, que não dava pra jogar } \\
\text { qualquer pedaço de energia lá. Ele tinha que ser múltiplo } \\
\text { do h, que é a constante de Planck. }\end{array}$ & $\begin{array}{l}\mathrm{O} \text { professor recorre as anotações do } \\
\text { quadro. }\end{array}$ & \\
\hline 7 & $\begin{array}{l}\text { 17(P) E no jogo de dados é a mesma coisa, eu não tenho } \\
\text { a meia casa, eu tenho a casa } 1 \text { e a casa } 2 \text {. A casa } 1,5 \text { (um } \\
\text { e meio) eu não tenho. }\end{array}$ & $\begin{array}{l}\text { Retoma a sua narrativa do jogo de } \\
\text { tabuleiro. }\end{array}$ & \\
\hline
\end{tabular}




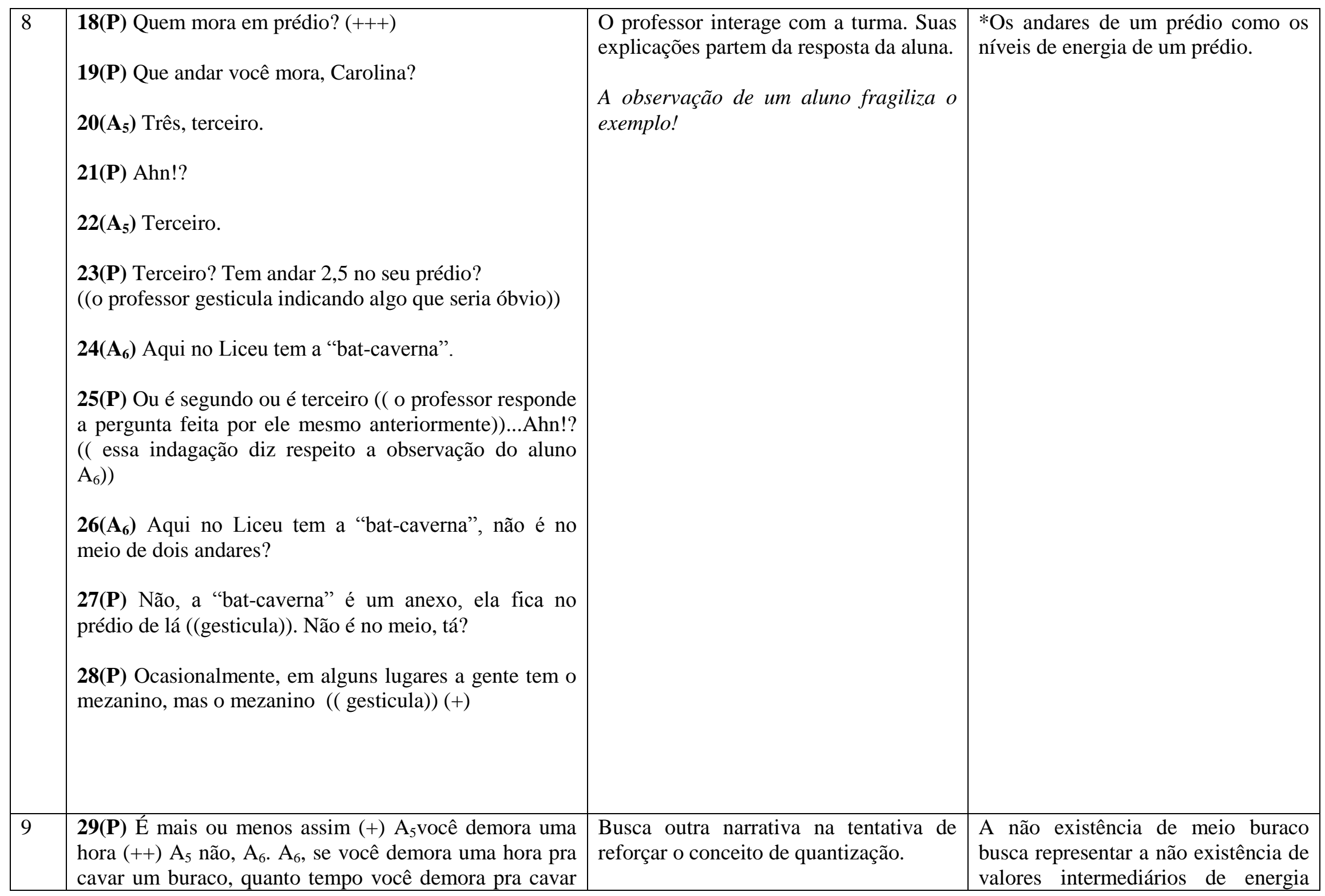




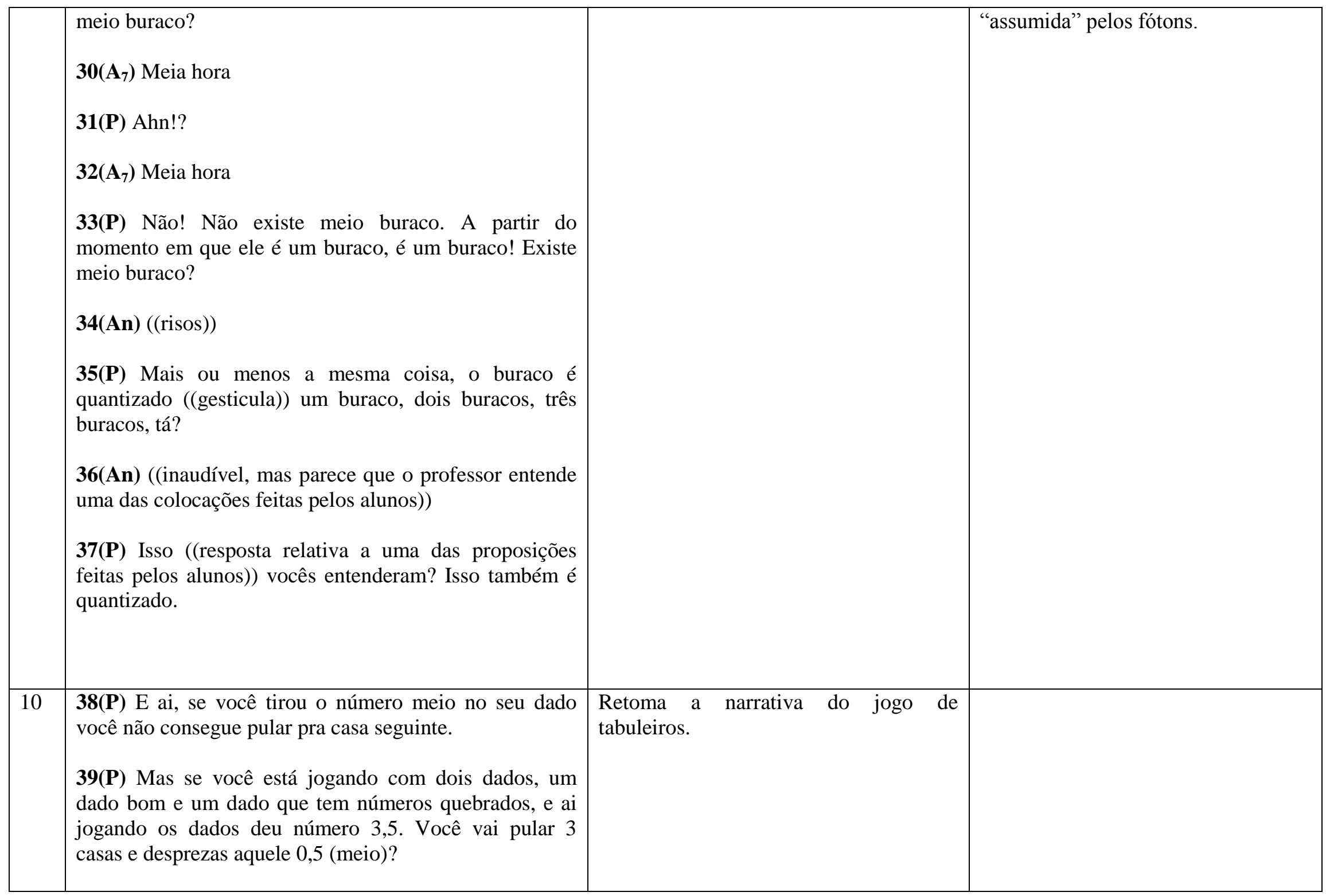




\begin{tabular}{|c|c|c|c|}
\hline & $\begin{array}{l}\text { 40(A) Não. } \\
\text { 41(P) Não, não dá! Ou você pula } 3 \text { casas ou } 4 \text { casas. Se } \\
\text { não dá pra você pular } 3 \text { casas e meia, você não pula. } \\
\text { Você fica onde está. }\end{array}$ & & \\
\hline 11 & $\begin{array}{l}\text { 42(P) Isso é o que Einstein observou, isso é o que } \\
\text { Planck também observou. A quantidade de energia } \\
\text { precisa ser quantizada. Precisa ser um valor exato, um } \\
\text { múltiplo de } \mathrm{h}((\text { o professor se dirige novamente ao } \\
\text { quadro e aponta para o valor de h ali escrito)) múltiplo } \\
\text { desse valor aqui. } \\
\text { 43(P) Se não for assim não ocorre o fenômeno } \\
\text { fotoelétrico, tudo bem? Moleza? }\end{array}$ & $\begin{array}{l}\text { Conclusão a respeito da analogia } \\
\text { utilizada. }\end{array}$ & \\
\hline
\end{tabular}


Episódio 05 (MAT - 04 - 14032011- 02) - Energia dos estados quânticos

\begin{tabular}{|c|c|c|c|}
\hline \multicolumn{4}{|c|}{ Episódio 05 (MAT - 04 - 14032011- 02) - Energia dos estados quânticos } \\
\hline S. & No. Do turno (Sujeito) Transcrição & Ações no turno & $\begin{array}{l}\text { Identificação de elementos da } \\
\text { analogia. }\end{array}$ \\
\hline 1 & 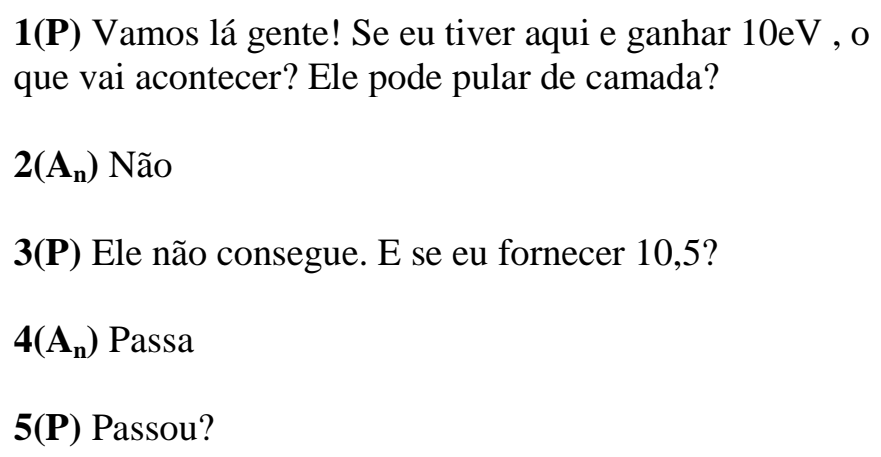 & $\begin{array}{l}\text { O professor recorre as anotações feitas } \\
\text { no quadro na qual ele destaca os níveis } \\
\text { de energia de cada subnível quântico do } \\
\text { átomo de hidrogênio. }\end{array}$ & \\
\hline 2 & $\begin{array}{l}\text { 6(P) Você mora em prédio? } \\
7\left(\mathbf{A}_{1}\right) \text { Não } \\
8(\mathbf{P}) \text { Você mora em prédio? } \\
9\left(\mathbf{A}_{2}\right) \text { Não } \\
10(\mathbf{P}) \text { Quem mora em prédio aqui? } \\
11(\mathbf{A}) \text { Eu! } \\
12(\mathbf{P}) \text { Óooo... Quem mora em prédio bem alto? } \\
13\left(\mathbf{A}_{4}\right) \text { Eu! } \\
14(\mathbf{P}) \text { Que andar você mora? }\end{array}$ & $\begin{array}{l}\text { Numa ação interativa, o professor } \\
\text { dialoga com os alunos na tentativa de } \\
\text { elucidar a relação entre energia } \\
\text { absorvida pelo elétron e sua mudança de } \\
\text { subnível quântico. }\end{array}$ & $\begin{array}{l}\text { Os andares de um prédio são } \\
\text { análogos aos subníveis quânticos. } \\
\text { Os botões de um elevador sinalizam } \\
\text { números inteiros limitando assim as } \\
\text { "posições" de parada e abertura de } \\
\text { porta durante a subida ou a descida } \\
\text { deste. Esta situação tenta representar } \\
\text { os estados quânticos como discretos } \\
\text { e não contínuos. }\end{array}$ \\
\hline
\end{tabular}




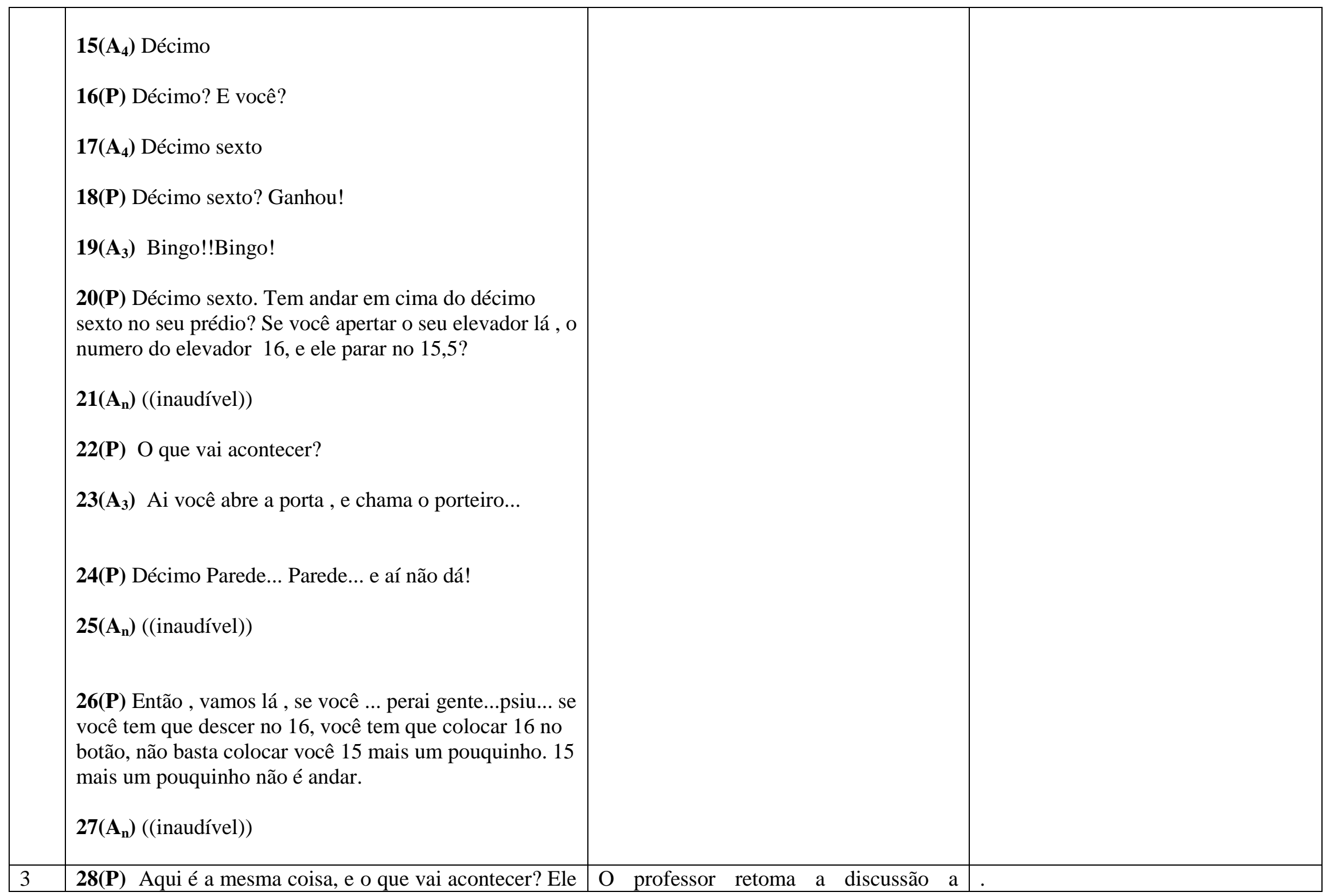




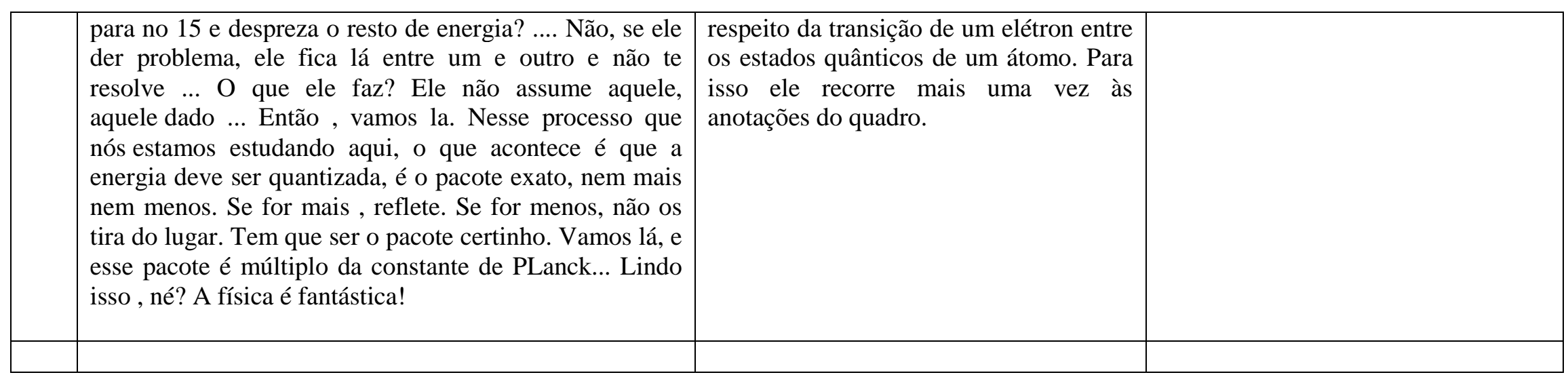


Episódio 06 (EFE/ NDL - 06 - 30112012- 01) -O efeito fotoelétrico - modelos ondulatório e corpuscular da luz.

\begin{tabular}{|c|c|c|c|}
\hline $\mathbf{S}$. & No. Do turno (Sujeito) Transcrição & Ações no turno & $\begin{array}{l}\text { Identificação de elementos da } \\
\text { analogia. }\end{array}$ \\
\hline 1 & $\begin{array}{l}1 \text { (P) Pessoal, no modelo ondulatório qual é a idéia de } \\
\text { luz? É que a luz, nessa idéia aqui, a luz pode ter } \\
\text { qualquer energia,qualquer um valor possível de energia, } \\
\text { a luz pode ter aqui. Segundo, a luz, ela é sempre } \\
\text { alguma coisa contínua, ela não é quebradinha, né? } \\
2 \text { (P) Então, quando eu olho para a onda, você percebe } \\
\text { ó, o tempo inteiro ela tem um valor, e esse valor, ele é } \\
\text { contínuo, ele não é, não é dividido né? Então, quando } \\
\text { você pensa no modelo ondulatório, você tem esse tipo de } \\
\text { representação pra luz. } \\
3 \text { (P) Só que aí, pelo efeito fotoelétrico a gente percebeu } \\
\text { o seguinte: que não dá para usar esse modelo para } \\
\text { explicar o efeito fotoelétrico, por que? Porque quando } \\
\text { você pensa nesse modelo, a gente sempre, na onda } \\
\text { assim: se você colocar uma intensidade maior, lembra } \\
\text { que a intensidade tem a ver com o tamanho da onda né? } \\
4 \text { (P) Então por exemplo, isso daqui é uma luz de baixa } \\
\text { intensidade. O que seria uma luz de alta intensidade } \\
\text { pensando nesse modelo? Seria alguma coisa assim ó } \\
\text { ó.((professor desenha no quadro)) Isso aqui é alta } \\
\text { intensidade ((professor desenha no quadro)), isso aqui é } \\
\text { baixo intensidade. }\end{array}$ & $\begin{array}{l}\text { O professor usa o quadro a fim de } \\
\text { representar a amplitude de uma onda } \\
\text { associada a sua intensidade. Em sua } \\
\text { representação pictórica ele acentua a } \\
\text { diferença de amplitudes entre dois trens } \\
\text { de ondas (um com baixo o outro com } \\
\text { alto valor). }\end{array}$ & \\
\hline & $\begin{array}{l}5 \text { (P) só que para você arrancar elétrons não depende } \\
\text { dessa intensidade, vai depender do quê? De um outro } \\
\text { fator, que é a freqüuência, tá bom? }\end{array}$ & & \\
\hline
\end{tabular}




\begin{tabular}{|c|c|c|c|}
\hline & $\begin{array}{l}\text { 6(P) Aí, como é que a gente mudou a nossa estratégia de } \\
\text { explicação. A gente tentou mostrar que com esse modelo } \\
\text { não dava para explicar, você arrancar elétrons do metal, } \\
\text { e a gente precisava de uma outra representação. }\end{array}$ & & \\
\hline 2 & $\begin{array}{l}7 \text { (P) Qual é que era a outra representação que a gente } \\
\text { usou? Como é que a gente representava agora a luz? Era } \\
\text { um outro modelo. Aqui era o modelo ondulatório, é } \\
\text { como se a luz fosse uma onda. Qual que é o modelo que } \\
\text { a gente usa para explicar aqui? Partículas de luz. } \\
\mathbf{8} \text { (P) Então, como é que é talvez o desenho que a gente } \\
\text { possa imaginar pra partículas de luz. Invés de você ficar } \\
\text { desenhando a onda assim para representar a luz, a gente } \\
\text { vai representar agora a luz dessa maneira ó ((professor } \\
\text { desenha no quadro)) é como se fossem partículas } \\
\text { mesmo. } \\
\mathbf{9} \text { (P) Então ó, cada representação dessa que eu to } \\
\text { fazendo é como se fosse o equivalente a isso ((professor } \\
\text { desenha no quadro)). Então , aqui eu tenho a luz na } \\
\text { forma de onda quando eu desenho a luz agora desse } \\
\text { jeito, eu to imaginado a luz como pequenas partículas, } \\
\text { então aqui são as partículas de luz. } \\
\mathbf{1 0} \text { (P) E aí, como é que a gente batizou, pessoal, essas } \\
\text { partículas de luz? A deu, a gente não, o Einstein deu um } \\
\text { nome para isso. Como é que é o nome que foi dado para } \\
\text { essas partículas de luz? Fótons. } \\
\mathbf{1 1} \text { (P) E aí qual é a idéia dos fótons? } \\
\mathbf{1 2} \text { (P) Toda vez que esses fótons, que são partículas } \\
\text { aqui, ó, elas batem no metal, cada fóton desse ó, cada }\end{array}$ & $\begin{array}{l}\text { O professor recorre ao quadro a fim de } \\
\text { representar a luz agora como um } \\
\text { conjunto de partículas representadas em } \\
\text { seu desenho por pequenas bolinhas. } \\
\text { Ainda com sua representação pictórica } \\
\text { dos trens de ondas ele faz contraste entre } \\
\text { os dois modelos. } \\
\text { Sua narrativa é enfatizada com gestos. }\end{array}$ & \\
\hline
\end{tabular}




\begin{tabular}{|c|c|c|c|}
\hline & $\begin{array}{l}\text { partícula dessa, dá toda energia dela para o elétron do } \\
\text { metal, e aí você consegue arrancar os elétrons do metal. } \\
\mathbf{1 3}(\mathbf{P}) \text { Aqui ... qual é a grande diferença daqui para essa } \\
\text { representação? Aqui a luz é como se fosse uma coisa } \\
\text { contínua, e ela pode ter qualquer valor de energia. } \\
\mathbf{1 4} \text { (P) Aqui nessa representação já muda } \\
\text { completamente, concorda? Aqui por exemplo, a luz não } \\
\text { é mais uma coisa contínua, é como se fosse uma coisa } \\
\text { granulada. }\end{array}$ & & \\
\hline 3 & $\begin{array}{l}15 \text { (P) Pessoal, vamos pensar nas gotas de chuva, se } \\
\text { você olhar a chuva caindo de longe, ela não tem esse } \\
\text { aspecto aqui ó ((desenha no quadro)), parece um coisa } \\
\text { contínua? Parece eu não tem divisão, a chuva quando tá } \\
\text { caindo. Mas se a gente fosse capaz de olhar a luz...a } \\
\text { chuva de um jeito mais Próximo, você percebe que a } \\
\text { chuva, ela não é contínua desse jeito, ela é formada de } \\
\text { pequenas gotículas. } \\
\mathbf{1 6} \text { (P) Então aqui ó((aponta pro desenho no quadro)), é } \\
\text { a representação que a gente tem hoje de como seria a } \\
\text { luz, a luz não é uma coisa contínua, a luz é formada por } \\
\text { partículas, essas partículas o Einstein né,acabou } \\
\text { batizando de fótons, e toda vez que esses fótons batem } \\
\text { aqui no metal, dependendo da energia que esses fótons } \\
\text { tiverem, você consegue arrancar elétrons, essa é a idéia. }\end{array}$ & $\begin{array}{l}\text { A fim de reforçar o contraste entre os } \\
\text { conceitos de "coisas discretas" x "coisas } \\
\text { continuas", o professor lança mão de } \\
\text { uma analogia que é apresentada em sua } \\
\text { narrativa e reforçada por representações } \\
\text { pictóricas no quadro. }\end{array}$ & $\begin{array}{l}\text { As gotas da chuva representam o } \\
\text { caráter discreto da luz. } \\
\text { A impressão de continuidade da } \\
\text { chuva representa a "falsa" impressão } \\
\text { do caráter contínuo da luz. }\end{array}$ \\
\hline 4 & $\begin{array}{l}17 \text { (P) Como é que é o nome desse modelo? Esse } \\
\text { modelo aqui, que substitui esse modelo para explicar o }\end{array}$ & $\begin{array}{l}\text { A ação do professor é discursiva e } \\
\text { conclusiva. No } \quad \text { entanto, como }\end{array}$ & \\
\hline
\end{tabular}




\begin{tabular}{|c|c|c|}
\hline $\begin{array}{l}\text { efeito foto-elétrico, esse é o chamado, modelo fóto- } \\
\text { corpuslar. } \\
18 \text { (P) Pessoal, por que foi usado a palavra corpuscular? } \\
\text { Tem a ver com corpúsculo, é como se fosse uma coisa, é } \\
\text { como se a luz não fosse fazer uma coisa contínua né, ela } \\
\text { fosse dividida em pequenas partículas. } \\
19 \text { (P) Pessoal, quanto vale cada par.., qual é a energia } \\
\text { de cada partícula dessa luz?Cada bolinhas dessa que eu } \\
\text { tô usando para representar a luz, se é que isso daqui de } \\
\text { fato é uma bolinha, né? Ó, cada fóton desse tem essa } \\
\text { energia ó (( escreve no quadro)), a energia de um fóton é } \\
\text { uma constante a natureza que é o h multiplicado pela } \\
\text { frequiência, então cada partícula dessa tem essa energia } \\
\text { aqui ó ((completa a anotação no quadro)). } \\
20 \text { (P) E aí o que você percebe? Que a energia não } \\
\text { depende da amplitude ó, não depende da intensidade, a } \\
\text { energia depende da frequiência, está ligado a isso. } \\
\text { Dependendo dessa freqüência eu vou conseguir } \\
\text { arrancar elétrons do elétrons ou não. }\end{array}$ & $\begin{array}{l}\text { ferramenta auxiliar, ele usa as } \\
\text { representações pictóricas realizadas } \\
\text { anteriormente e reforça agora com } \\
\text { representações matemáticas da equação } \\
\text { da energia de um fóton }(E=h . v) \text { a partir } \\
\text { da qual destaca que a energia não } \\
\text { depende da amplitude, mas sim da } \\
\text { frequência da luz em questão. }\end{array}$ & \\
\hline $\begin{array}{l}21 \text { (P) Então, aqui é uma coisa contínua, aqui ela não é } \\
\text { contínua. Aqui a energia só pode ter determinados } \\
\text { valores ó. Você percebe quando você faz essa ponta, a } \\
\text { energia não tem qualquer valor, ela só vai ter valores } \\
\text { bem definidos, que vai ser exatamente a multiplicação } \\
\text { do h ( que é uma constante da natureza) multiplicado } \\
\text { pelo frequiência. }\end{array}$ & & \\
\hline
\end{tabular}




\begin{tabular}{|c|c|c|c|}
\hline $\mathbf{S .}$ & No. Do turno (Sujeito) Transcrição & Ações no turno & $\begin{array}{l}\text { Identificação de elementos da } \\
\text { analogia. }\end{array}$ \\
\hline 1 & $\begin{array}{l}\text { 1(P) O a terceira interpretação: o fóton é composto de } \\
\text { duas partes(+) olha que coisa }(+) \text { que pensamento } \\
\text { estranho, o fóton é composto de duas partes: ele é uma } \\
\text { partícula e é uma onda associada. }\end{array}$ & $\begin{array}{l}\text { O professor tem como guia de leitura um } \\
\text { slide que é projetado numa tela na frente } \\
\text { do quadro. }\end{array}$ & \\
\hline 2 & $\begin{array}{l}\text { 2(P) É como se você pensasse assim ó(+) assim a } \\
\text { partícula é como se fosse um surfista viajando sobre uma } \\
\text { onda e só pode... ó e só pode estar onde existe a onda } \\
\text { 3(P) É como se fosse alguma coisa assim ó(+) onde } \\
\text { tiver a onda ó, onde tiver uma onda }(+) \text { junto da onda } \\
\text { você vai ter também uma partícula. Você vai ter os dois } \\
\text { juntos. Você vai ter a onda e você vai ter também a } \\
\text { partícula. }\end{array}$ & $\begin{array}{l}\text { Associado a sua narrativa da analogia, o } \\
\text { professor utiliza representações } \\
\text { pictóricas que ele faz no quadro. }\end{array}$ & $\begin{array}{l}\text { O surfista na onda representa o fóton } \\
\text { associado a onda na interpretação } \\
\text { dualista-realista. }\end{array}$ \\
\hline 3 & $\begin{array}{l}\mathbf{4 ( P )} \text { Se lembra que as meninas falaram isso na aula } \\
\text { passada? Ah (+) por que não pode ser os dois ao mesmo } \\
\text { tempo? } \\
\mathbf{5 ( P )} \text { Então (++) onde tiver onda você vai ter o que? (+) } \\
\text { Partícula } \\
\text { 6(P) Então vamos ver aqui o que ele fala óóó (+) éééé } \\
\text { onde existe a partícula também vai ter onda. }\end{array}$ & $\begin{array}{l}\text { O professor retoma a orientação da } \\
\text { projeção e lê alguns dos tópicos do slide. }\end{array}$ & \\
\hline 4 & 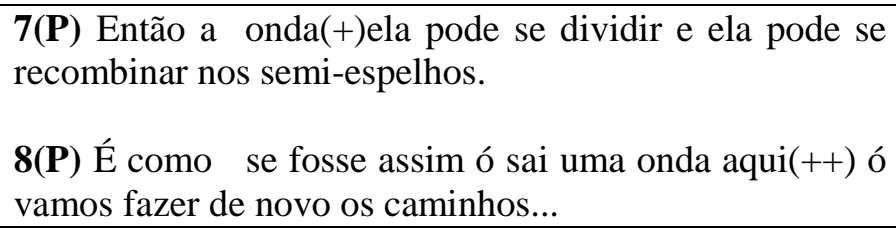 & $\begin{array}{l}\text { No quadro há uma representação } \\
\text { pictórica simplificada do interferômetro } \\
\text { de Mach-Zehnder a partir da qual o } \\
\text { professor se baseia para encaminhar a } \\
\text { presente discussão. }\end{array}$ & \\
\hline
\end{tabular}




\begin{tabular}{|c|c|c|c|}
\hline \multicolumn{4}{|c|}{ Episódio 08 (EFE - 08 - 22112012- 04) - Efeito fotoelétrico } \\
\hline S. & No. Do turno (Sujeito) Transcrição & Ações no turno & $\begin{array}{l}\text { Identificação de elementos da } \\
\text { analogia. }\end{array}$ \\
\hline 1 & $\begin{array}{l}\text { 1(P) Uma onda bate no material ela consegue ter uma } \\
\text { interferência com esse material(+) ela tem uma relação } \\
\text { com esse material tá? Uma interação com esse material. }\end{array}$ & $\begin{array}{l}\text { O professor buscava evidenciar que a } \\
\text { partir do modelo ondulatório da luz não } \\
\text { se conseguia explica o efeito } \\
\text { fotoelétrico. }\end{array}$ & \\
\hline 2 & $\begin{array}{l}\text { 2(P) Por exemplo(+) no caso da ponte que a gente viu a } \\
\text { ponte ((gestos)) como é que você explica aquilo lá? } \\
\text { 3(P) A onda vem }((\text { gestos }))(+) \text { o vento vem e aí a ponte } \\
\text { começa a balançar. Quando a ponte tá balançando }(+) \\
\text { quando ela tá voltando pro movimento dela lá }(+) \text { pra } \\
\text { parar (+) áá }(++) \text { o ar vem (+) né o vento }(+) \text { a onda do } \\
\text { ar bate e aumenta a amplitude e aí ela vem }(+) \text { quando } \\
\text { ela tá voltando bate de novo e aí ela vai aumentando a } \\
\text { amplitude (+) né? A ponte }(++) \text { até uma hora que ela cai. } \\
\text { 4(P) Isso a onda explica, o modelo ondulatório explica } \\
(+) \text { é um negócio super básico né? (+) vai } \\
\text { empurrando }(+) \text { vai empurrando e chega uma hora que } \\
\text { começa (++) ah ela balança também (+) você vai } \\
\text { empurrando vai empurrando vai aumentando a } \\
\text { amplitude e tal }(+) \text { tem uma hora que não aguenta }(+) \\
\text { não se sustenta mais e cai. } \\
\text { 5(P) O problema é }(+) \text { esse tipo de explicação demora } \\
(+) \text { esse tipo de efeito demora muito }(+) \text { então pra cair a } \\
\text { ponte demora. }\end{array}$ & $\begin{array}{l}\text { O professor inicia uma narrativa de uma } \\
\text { situação na qual uma ponte desaba sob a } \\
\text { ação do vento. Ele buscou a analogia da } \\
\text { ponte a fim de contrastar com as } \\
\text { previsões do experimento relativo ao } \\
\text { efeito fotoelétrico. }\end{array}$ & $\begin{array}{l}\text { A ação do vento sobre a ponte é o } \\
\text { análogo da ação da luz sobre uma } \\
\text { placa metálica. }\end{array}$ \\
\hline
\end{tabular}




\begin{tabular}{|c|c|c|c|}
\hline 3 & $\begin{array}{l}\text { 6(P) Nesse caso aqui daria pra você explicar por } \\
\text { exemplo com o modelo de onda porque quando bate a } \\
\text { luz na placa sai elétron ((gestos)) dá pra explicar só que } \\
\text { aí demora muito tempo. } \\
\text { 7(P) Então bate a luz (+) a onda luminosa ((gestos)) a } \\
\text { parte de cima da placa começa (+) começaria } \\
\text { movimentar como se fosse a ponte até uma hora que os } \\
\text { elétrons começam a sair. } \\
\mathbf{8 ( P )} \text { Começam na verdade a desmanchar a desmanchar } \\
\text { seria mais ou menos isso }(+) \text { entre aspas tá? ((reforça } \\
\text { com gestos indicando aspas)) desmanchar (++) e aí } \\
\text { começa a sair elétrons (++) e aí (+) só que por um longo } \\
\text { tempo. } \\
\mathbf{9 ( P ) ~ A i ́ ~ a ~ g e n t e ~ p e r c e b e ~ q u e ~ q u a n d o ~ b a t e ~ a ~ l u z ~ ( ( g e s t o s ) ) ~} \\
\text { na hora sai o elétron }(+) \text { esse é o problema. } \\
\mathbf{1 0 ( P ) ~ O u t r o ~ p r o b l e m a ~ e ́ ~ v o c e ̂ ~ a u m e n t a r ~ a ~ i n t e n s i d a d e ~} \\
\text { luminosa (+) então você aumenta ali aaa (++) coloca } \\
\text { uma luz mais forte entre aspas }(+) \text { coloca uma luz mais } \\
\text { clara (+) deveria }(+++)\end{array}$ & $\begin{array}{l}\text { A partir da analogia da ponte o professor } \\
\text { retoma a discussão do efeito } \\
\text { fotoelétrico. Nesse momento ele inclui o } \\
\text { fator intervalo de tempo para o início do } \\
\text { fenômeno. }\end{array}$ & \\
\hline 4 & $\begin{array}{l}\text { 11(P) É como se fosse um vento mais forte } \\
\text { 12(P) (+) deveria ééé }(++) \text { o efeito ser mais imediato } \\
\text { ainda }\end{array}$ & $\begin{array}{l}\text { Retoma rapidamente a analogia da ponte } \\
\text { e reforça a questão do fator intervalo de } \\
\text { tempo no referido efeito. }\end{array}$ & \\
\hline
\end{tabular}




\begin{tabular}{|c|c|c|c|}
\hline & & & \\
\hline 5 & $\begin{array}{l}\text { 13(P) Só que se você coloca a luz mais intensa(+) num } \\
(+) \text { não acontece isso. } \\
\text { 14(P) Só vai mudar quando você muda a frequência }(+) \\
\text { quando você muda a cor da luz }(+) \text { quando você muda o } \\
\text { comprimento de onda. } \\
\text { 15(P) Então pra uns tipos de luz dá o efeito fotoelétrico } \\
(+) \text { pra outros tipos não dá }(+) \text { e aí era um problema } \\
\text { também. }\end{array}$ & $\begin{array}{l}\text { Conclui que apresentando as previsões } \\
\text { do efeito fotoelétrico a respeito da } \\
\text { variação da amplitude e da variação da } \\
\text { frequência da luz incidente no material. } \\
\text { Vale destacar que os alunos participaram } \\
\text { de uma aula na qual eles utilizaram um } \\
\text { simulador do efeito fotoelétrico e } \\
\text { "verificaram" as observações feitas aqui } \\
\text { pelo professor. }\end{array}$ & \\
\hline
\end{tabular}

